UNIVERSIDADE DE SÃO PAULO

FACULDADE DE ECONOMIA, ADMINISTRAÇÃO E CONTABILIDADE DEPARTAMENTO DE CONTABILIDADE E ATUÁRIA

RELAÇÃO ENTRE MECANISMOS DE GOVERNANÇA CORPORATIVA E MEDIDAS DE PERFORMANCE ECONÔMICA DAS EMPRESAS BRASILEIRAS INTEGRANTES DO ÍNDICE BRASIL DA BOLSA DE VALORES DE SÃO PAULO

JOSÉ DANÚBIO ROZO

ORIENTADOR:

PROF. DR. LUIZ NELSON GUEDES DE CARVALHO

SÃO PAULO

2003 
Reitor da Universidade de São Paulo

Prof. Dr. Adolpho José Melfi

Diretora da Faculdade de Economia, Administração e Contabilidade

Profa. Dra. Maria Tereza Leme Fleury

Chefe do Departamento de Contabilidade e Atuaria

Prof. Dr. Reinaldo Guerreiro 


\section{RELAÇÃO ENTRE MECANISMOS DE GOVERNANÇA CORPORATIVA E MEDIDAS DE PERFORMANCE ECONÔMICA DAS EMPRESAS BRASILEIRAS INTE- GRANTES DO ÍNDICE BRASIL DA BOLSA DE VALORES DE SÃO PAULO}

\section{JOSÉ DANÚBIO ROZO}

Tese apresentada ao Departamento de Contabilidade e Atuària da Faculdade de Economia, Administração e Contabilidade da Universidade de São Paulo para obtenção do título de Doutor em Controladoria e Contabilidade.

Orientador: Prof. Dr. Luiz Nelson Guedes de Carvalho

\section{SÃO PAULO}


Este trabalho é dedicado a meus pais Guilherme e Élida e a meus filhos Danúbio, Lívia, Taline e Tales. 


\section{AGRADECIMENTOS}

É indubitável que um tabalho desta natureza envolve um expressivo número de pessoas que nos incentivam, oferecem comentários, sugestões e críticas construtivas. Agradecê-las é um ato muito singelo se comparado com o muito que nos ofereceram, uma colaboração que nos será de grande valia para o resto de nossa vida. Citá-las é assumir o risco elevado de omitirmos nomes e cometermos injustiças. Porém, preferimos assumir esse risco, ao tempo em que encarecemos desculpas aos que não citamos, mas que somos eterna e igualmente gratos.

Agrademos:

- Ao professor Barbieri que durante o MBA Controller despertou-nos para o desafio da vida acadêmica;

- Aos colegas Pinto e Walter, pelo estímulo nos momentos decisivos;

- Ao professor Iran que manifestou seu apoio incondicional mesmo antes de começarmos o curso e tem sido um exemplo no qual nos pautamos;

- Ao nosso orientador professor Nelson, pela confiança depositada, pela valiosa colaboração desde os primeiros dias de aula com críticas minuciosas, que bem revelam sua competência e dedicação a tudo que faz;

- Ao professor Gilberto, pelo exemplo de atuação em aula, pelo encorajamento `a produção científica de carátcer empírico e pelas críticas fundamentais à consecução deste trabalho;

- Ao colega e professor Alexsandro, pelo convívio e contribuições inestimáveis; 
- Aos colegas do Banco do Brasil, Alberto, Marcelo, Fernando, Zimdars, Fernanda, Paula e tantos outros, pela colaboração na coleta de dados, discussão e revisão dos textos;

- A todos os professores, pelos ensinamentos e pelas críticas diárias cujos propósitos entendemos sempre como um estímulo a aperfeiçoar, desfazer, criar e recriar em busca do progresso constante;

- Aos colegas de aula, pelo privilégio do convívio, coleguismo e contribuições aos nossos trabalhos em aula;

- Aos meus familiares, em especial meus filhos, pela privação de nosso convívio, dívida que não poderemos pagar;

- A meus pais, meus eternos heróis, pelos ensinamentos de retidão de caráter, espírito de luta e autoconfiança;

- Por fim, ao Banco do Brasil S.A., pelo apoio institucional, sem o qual este trabalho não existiria. 
In the operation of the corporation, the controlling group even if they own a large block of stock, can serve their own pockets better by profiting at the expense of the company than by making profits for it (BERLE; MEANS, 1932). 


\section{RESUMO}

Até cerca de vinte anos, o termo Corporate Governance (Governança Corporativa) não existia na língua inglesa. Os códigos de boas práticas de Governança Corporativa começaram a surgir no início dos anos noventa na Inglaterra, nos Estados Unidos e no Canadá, em resposta ao desempenho insatisfatório de companhias líderes, percebido como uma deficiência de efetividade dos conselhos de administração, e em resposta às pressões exercidas pelos investidores institucionais. No Brasil, o termo Governança Corporativa é ainda mais recente, mas já começa a ser preocupação e a merecer a atenção de pesquisadores, Bolsa de Valores e associações. Este estudo objetiva identificar possíveis relações entre variáveis independentes, representativas de mecanismos de Governança Corporativa, e medidas de performance econômica de empresas integrantes do Índice Brasil - IBX da Bolsa de Valores de São Paulo BOVESPA, com dados do período de 1997 a 2001.Utilizando a técnica estatística de dados em painel, modelo de componentes de erros, trabalha-se 16 variáveis independentes representando os mecanismos de Governança Corporativa: concentração de propriedade (5 variáveis), características do conselho de administração (3 variáveis), capital votante (1 variável), remuneração da diretoria executiva (2 variáveis), política financeira (3 variáveis), controle interno (1 variável) e mais uma variável de controle representando o tamanho das empresas. Essas variáveis são regredidas contra cada uma das cinco variáveis de medidas de performance econômica estudadas. Tais variáveis mediram o Market Value Added, a razão preço de mercado e valor patrimonial da ação, TOBIN'S Q, rentabilidade sobre o ativo e rentabilidade sobre o patrimônio líquido. Os resultados indicam que a concentração de propriedade, o capital votante, a remuneração da diretoria executiva e a política financeira são relacionadas à performance econômica. Surpreendentemente, o capital votante e a remuneração da diretoria executiva são negativamente relacionados à performance. Observa-se, também, que a medida de performance econômica utilizada faz diferença no estudo dos mecanismos de Governança Corporativa, pois aquelas puramente contábeis não apresentaram qualquer relação com os mecanismos testados. Este estudo, com esta abrangência de mecanismos, variáveis e período tratado, está dentre os estudos empíricos de Governança Corporativa pioneiros no Brasil. Espera-se oferecer uma contribuição aos acadêmicos interessados no assunto, bem como a acionistas, gestores, analistas de mercado, consultores, administradores de Bolsa de Valores, órgãos reguladores e associações de classe. 


\begin{abstract}
Up until twenty years go, the term Corporate Governance didn't exist in the English language. The codes of good practices of Corporate Governance began to arise in the early nineties in England, in the United States and in Canada, as an answer to an unsatisfactory performance of leading companies - recognized as a deficiency of effectiveness in the board of directors - and also as an answer to the pressures exerted by institutional investors. In Brazil, the term Corporate Governance is still more recent, but begins to be pondered and to deserve attention of researchers, of Stock Exchanges and associations. This study aims to identify possible relationship among independent variables, representative of Corporate Governance mechanisms, and measures of economic performance of enterprises of the Brazil Index - IBX of the São Paulo Stock Exchange - BOVESPA, with data referring to the period comprehended between 1997 and 2001. Using the statistic technique of panel data, model of error components, we work with 16 independent variables representing the Corporate Governance mechanisms: concentration of propriety (5 variables), characteristics of the board of directors ( 3 variables), voting capital (1 variable), remuneration of the executive directorate ( 2 variables), financial policy (3 variables), internal control (1 variable), and one more control variable, representing the size of the enterprises. These variables are regressed against each one of the five variables of the studied economic performance measures. Such variables have measured up the Market Value Added, the market to book value price ratio, TOBIN'S Q, profitability over the assets and profitability over the net equity. The results indicate that the property concentration, the voting capital, the remuneration of the executive directorate and the financial policy are related to the economic performance. Surprisingly, the voting capital and the remuneration of the executive directorate are negatively related to performance. We can also observe that the economic performance measure utilized makes difference in the study of the Corporate Governance mechanisms, because that ones purely accountants doesn't have any relation with the mechanisms tested. This study, comprising such diverse mechanisms, variables and also the observed period, is among the leading empiric studies of Corporate Governance in Brazil. We hope to offer a contribution to the academics holding an interest in the matter, as well as to shareholders, managers, market analysts, consultants, Stock Exchange administrators, regulating bodies and class associations.
\end{abstract}




\section{SUMÁRIO}

LISTA DE FIGURAS E GRÁFICOS. XIV

LISTA DE TABELAS. . $\mathrm{XV}$

CAPÍTULO I...

INTRODUÇÃO

1

1.1 ANTECEDENTES E IMPORTÂNCIA DO ESTUDO …………………………..... 1

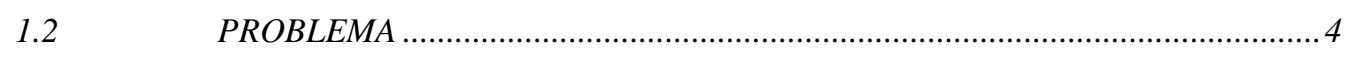

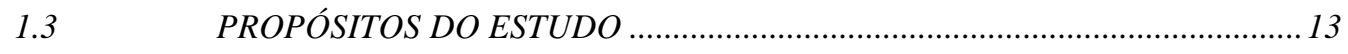

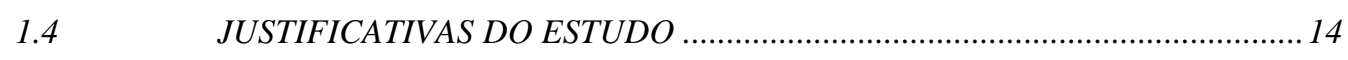

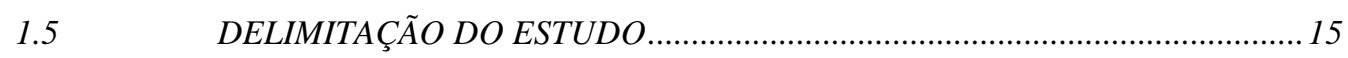

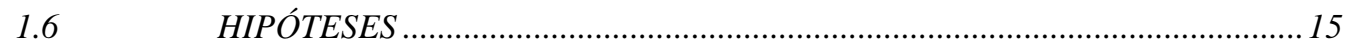

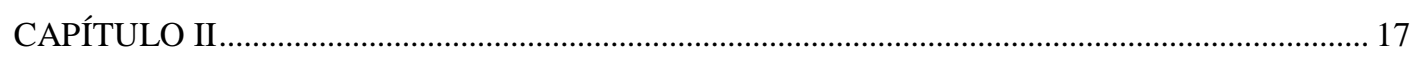

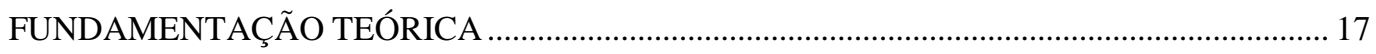

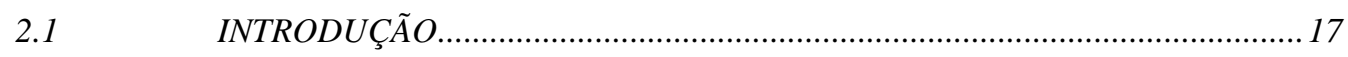

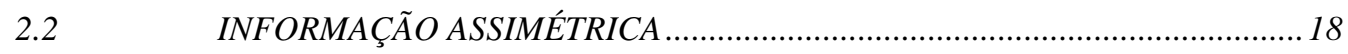

2.3 PROBLEMA DA RELAÇÃO PRINCIPAL-AGENTE ……….........................2

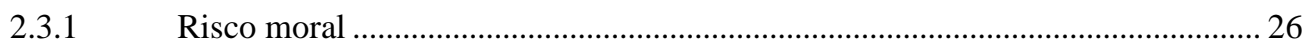

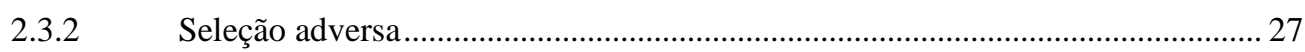

$2.4 \quad$ FIRMA

2.4.1 Firma na teoria econômica neoclássica ………………………………………..... 29

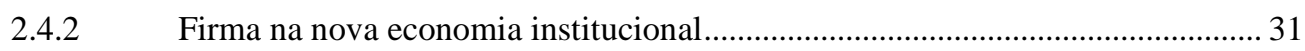

2.4.3 Firma e o problema principal-agente.............................................................. 41

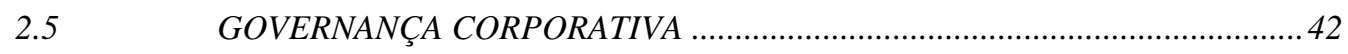

2.6 GOVERNANÇA CORPORATIVA E CONTABILIDADE .................................4

2.7 EVIDÊNCIAS EMPÍRICAS DE MECANISMOS DE GOVERNANÇA

CORPORATIVA E HIPÓTESES SUBJACENTES................................................ 
2.7.1 Concentração de propriedade ............................................................................ 53

2.7.2 Características do conselho de administração................................................ 55

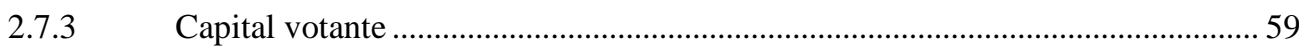

2.7.4 Política de remuneração da diretoria executiva ............................................... 60

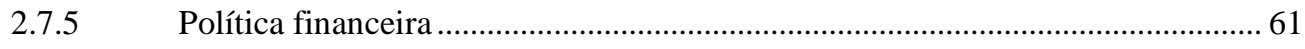

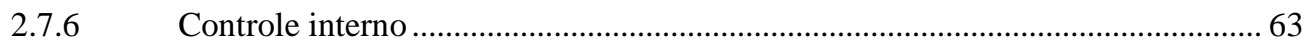

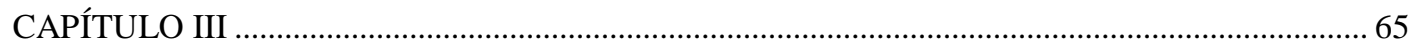

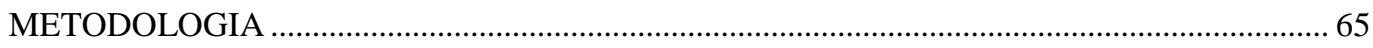

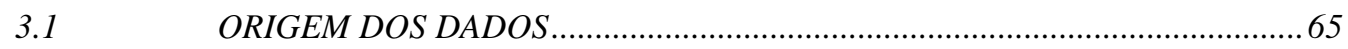

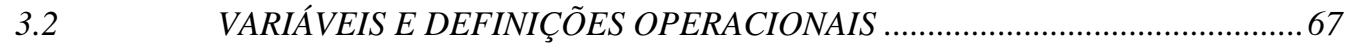

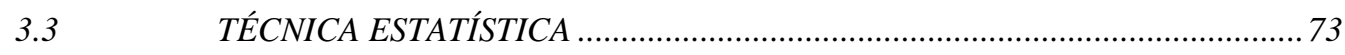

3.3.1 Modelo geral ............................................................................................ 75

1.1.2 Modelos de componentes de erro .............................................................. 76

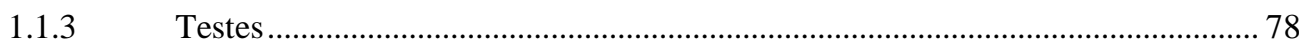

1.1.4 Heterocedasticidade e autocorrelação …........................................................ 81

MODELO DO ESTUDO

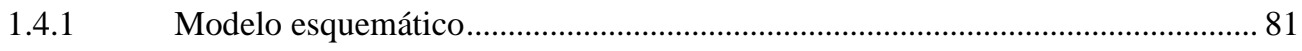

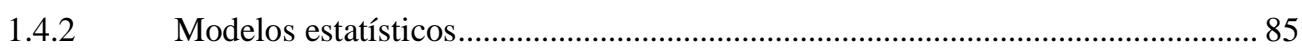

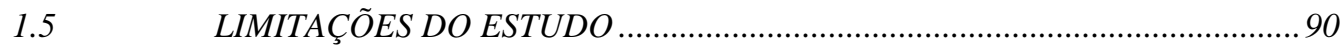

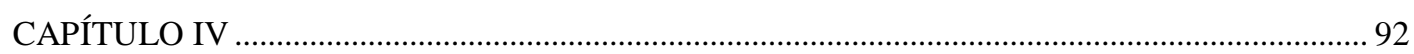

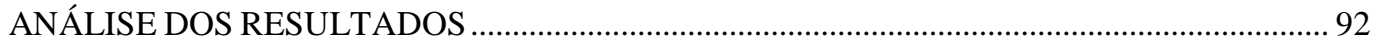

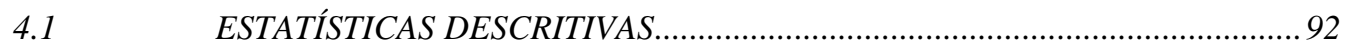

MATRIZ DE CORRELAÇÕES

REGRESSÕES COM DADOS EM PAINEL ............................................... 102

4.3.1 Variável dependente MVA - Market Value Added .......................................... 104

4.3.1.1 Modelo de efeitos fixos - uma direção ................................................................. 104

4.3.1.2 Modelo de efeitos fixos - duas direções ......................................................... 108

4.3.2 Variável dependente P_VPA - preço sobre o valor patrimonial das ações...... 112 
4.3.2.1 Modelo de efeitos fixos - uma direção

4.3.2.2 Modelo de efeitos fixos - duas direções

4.3.3 Variável dependente TOBIN'S Q - valor da empresa sobre o valor total dos ativos

4.3.3.1 Modelo de efeitos fixos - uma direção 122

4.3.3.2 Modelo de efeitos fixos - duas direções 126

4.3.4 Variável dependente RENT_ATI - rentabilidade do ativo. 131

4.3.4.1 Modelo de efeitos fixos - uma direção 131

4.3.4.2 Modelo de efeitos fixos - duas direções 134

4.3.5 Variável dependente RENT_PL - rentabilidade do patrimônio líquido... 138

4.3.5.1 Modelo de efeitos fixos - uma direção 138

4.3.5.2 Modelo de efeitos fixos - duas direções 142

CAPÍTULO V 146

CONCLUSÕES E SUGESTÕES PARA NOVOS ESTUDOS ... 146

5.1 CONCLUSÕES 146 


\section{LISTA DE FIGURAS E GRÁFICOS}

FIGURA 1 - MODELO BÁSICO DE COMPANHIA COM PROPRIEDADE SEPARADA DA GESTÃO ........5 FIGURA 2 - MODELO BÁSICO DE COMPANHIA COM ACIONISTAS MINORITÁRIOS E MAJORITÁRIOS . .10

FIGURA 3 - MODELO ESQUEMÁTICO DO ESTUDO .84

GRÁFICO 1- ACIONISTAS DAS TRÊS MAIORES EMPRESAS AMERICANAS - 1929 .7 


\section{LISTA DE TABELAS}

TABELA 1 - DEMONSTRATIVO DA FORMAÇÃO DA AMOSTRA DO ESTUDO . .67

TABELA 2 - ESTATÍSTICAS DESCRITIVAS DE TODAS AS VARIÁVEIS DO ESTUDO.. . .94

TABELA 3 - Matriz de CORRELAÇÕES DE TODAS AS VARIÁVEIS DO ESTUDO .100

TABELA 4 - RESULTADOS DA REGRESSÃO COM MVA COMO VARIÁVEL DEPENDENTE MODELO DE EFEITOS FIXOS E UMA DIREÇÃO. .106

TABELA 5 - RESULTADOS DA REGRESSÃO COM MVA COMO VARIÁVEL DEPENDENTE MODELO DE EFEITOS FIXOS E DUAS DIREÇÕES .110

TABELA 6 - RESULTADOS DA REGRESSÃO COM P_VPA COMO VARIÁVEL DEPENDENTE MODELO DE EFEITOS FIXOS E UMA DIREÇÃO .115

TABELA 7 - RESULTADOS DA REGRESSÃO COM P_VPA COMO VARIÁVEL DEPENDENTE MODELO DE EFEITOS FIXOS E DUAS DIREÇÕES .119

TABELA 8 - RESULTADOS DA REGRESSÃO COM TOBINS'Q COMO VARIÁVEL DEPENDENTE MODELO DE EFEITOS FIXOS E UMA DIREÇÃO. .124

TABELA 9 - RESULTADOS DA REGRESSÃO COM TOBINS'Q COMO VARIÁVEL DEPENDENTE MODELO DE EFEITOS FIXOS E DUAS DIREÇÕES .128

TABELA 10 - RESULTADOS DA REGRESSÃO COM RENT_ATI COMO VARIÁVEL DEPENDENTE MODELO DE EFEITOS FIXOS E UMA DIREÇÃO .132

TABELA 11 - RESULTADOS DA REGRESSÃO COM RENT_ATI COMO VARIÁVEL DEPENDENTE MODELO DE EFEITOS FIXOS E DUAS DIREÇÕES .136

TABELA 12 - RESULTADOS DA REGRESSÃO COM RENT_PL COMO VARIÁVEL DEPENDENTE MODELO DE EFEITOS FIXOS E UMA DIREÇÃO .139

TABELA 13 - RESULTADOS DA REGRESSÃO COM RENT_PL COMO VARIÁVEL DEPENDENTE MODELO DE EFEITOS FIXOS E DUAS DIREÇÕES 


\section{Capítulo I}

\section{INTRODUÇÃO}

\subsection{ANTECEDENTES E IMPORTÂNCIA DO ESTUDO}

Em que pese algumas questões relativas à Governança Corporativa terem sido enunciadas por Berle; Means em 1932, até vinte anos atrás, o termo Corporate Governance não existia na língua inglesa (ZINGALES, 1997).

Os códigos de boas práticas de Governança Corporativa começaram a surgir no início dos anos noventa na Inglaterra (Cadbury Report), nos Estados Unidos (General Motors Board of Directors Guidelines) e no Canadá (Dey Report) em resposta ao desempenho insatisfatório de companhias líderes, percebido como uma deficiência de efetividade dos conselhos de administração, e em resposta às pressões exercidas pelos investidores institucionais (GREGORY, 2000).

No Brasil, o termo Governança Corporativa é ainda mais recente, mas já começa a ser preocupação e a merecer a atenção de pesquisadores, Bolsa de Valores e associações de classe. Em 1995 foi fundado o Instituto Brasileiro de Governança Corporativa (IBGC). A Bolsa de Valores de São Paulo (BOVESPA)implantou, em dezembro de 2000, o Novo Mercado e os níveis diferenciados de Governança Corporativa. Cursos de Governança Corporativa já começam a ser demandados por integrantes de conselhos de administração e conselhos fiscais e o termo já surge como disciplina de cursos de MBA em diversas instituições de ensino. 
Mas qual é o significado de Governança Corporativa? Dentre as várias definições existentes na literatura, ainda não consensuais provavelmente pela tenra idade dos estudos sobre o assunto, encontram-se as seguintes:

"Corporate governance is a field in economics that investigates how to secure/motivate efficient management of corporations by the use of incentive mechanisms, such as contracts, organizational designs and legislation" (MATHIESEN, 2002). ${ }^{1}$

"Corporate governance deals with the ways in which suppliers of finance to corporations assure themselves of getting a return on their investment" (SHLEIFER; VISHNY, 1997, p. 737)2

Governança Corporativa são as práticas e os relacionamentos entre os acionistas/cotistas, conselhos de administração, diretoria, auditoria independente e conselho fiscal, com a finalidade de otimizar o desempenho da empresa e facilitar o acesso ao capital (IBGC, 2002).

"Corporate governance is the relationship among various participants in determining the direction and performance of corporations" (MONKS; MINOW, 2001$, p. 1$)^{3}$

Neste estudo adota-se a definição de Denis; Mcconnell (2002, p.1):

${ }^{1}$ Governança Corporativa é o campo da economia que investiga como assegurar/motivar uma administração eficiente das corporações pelo uso de mecanismos de incentivo, como contratos, estrutura organizacional e legislação (tradução nossa).

2 Governança corporativa trata da maneira como os supridores de fundos para as corporações asseguram para si um retorno sobre o seu investimento (tradução nossa).

${ }^{3}$ Governança corporativa é o relacionamento entre os vários participantes na determinação do rumo e do desempenho das corporações (tradução nossa). 
We define corporate governance as the set of mechanisms - both institutional and market-based - that induce the self-interested controllers of a company (those that make decisions regarding how the company will be operated) to make decisions that maximize the value of the company to its owners (the suppliers of capital). ${ }^{4}$

O tema Governança Corporativa é interdisciplinar e tem encontrado espaço na economia, em finanças, no direito, na administração e na contabilidade. Pode ser abordado sob a ótica estrita do problema principal-agente, enfocando os principais acionistas da empresa, ou, de forma mais abrangente, incluindo a preocupação com acionistas minoritários, com demais provedores de capital e até mesmo com todos os que possuem algum interesse na organização (stakeholders).

Os estudos do tema Governança Corporativa relacionados à performance econômica, objeto desta pesquisa, têm tratado uma ou duas variáveis como medidas de performance econômica e mecanismos de Governança isolados, com poucas variáveis explicativas. São exceções os trabalhos de Bohren; Odegaard (2001) e Coles; Mcwilliams; Sen (2001).

No Brasil, são escassos os estudos empíricos sobre Governança Corporativa, mormente os que relacionam mecanismos de Governança com medidas de performance econômica. A quantidade de mecanismos aqui estudados inclui este trabalho no grupo das pesquisas pioneiras no Brasil e insere a academia brasileira no reduzido grupo de estudos abrangentes sobre o tema internacionalmente.

Por isso, este estudo pode interessar a acadêmicos, acionistas minoritários, acionistas controladores, investidores institucionais, gestores, analistas de mercado, consultores, administradores de Bolsa de Valores, órgãos reguladores e associações de classe.

O trabalho está organizado em cinco capítulos. O capítulo I é introdutório,

${ }^{4}$ Nós definimos governança corporativa como um conjunto de mecanismos - tanto institucional como de mercado - que induzem os interesses próprios dos controladores de uma companhia ( aqueles que tomam as decisões de como a companhia irá operar) a tomar decisões que maximizem o valor da companhia para os seus donos (os fornecedores de capital) (tradução nossa). 
contextualiza o tema, discorre sobre as bases do problema objeto de estudo e sobre os objetivos estabelecidos. O capítulo II ocupa-se da fundamentação teórica e da formulação de hipóteses a serem testadas. O capítulo III apresenta a metodologia de trabalho empregada. O capítulo IV discute os resultados e o capítulo $\mathrm{V}$ evidencia as principais conclusões e sugere outros estudos.

\subsection{PROBLEMA}

Na idade média, as instituições econômicas dominantes nas cidades eram as corporações de ofício - associações artesanais, profissionais e de ofício - que existiam desde o Império Romano. Quem quisesse produzir ou vender qualquer bem ou serviço teria que entrar para uma corporação de ofício (HUNT, 1981, p.31).

Por volta do século XVI; o tipo de indústria artesanal, onde o artesão era proprietário de sua oficina, de suas ferramentas e matérias-primas e funcionava como um pequeno produtor independente; tinha sido largamente substituído, nas indústrias de exportação, pelo sistema de trabalho doméstico. No início da utilização desse sistema, o capitalista comerciante fornecia a matéria-prima ao artesão independente e lhe pagava uma quantia para transformá-la em produtos acabados. Desse modo, o capitalista era proprietário do produto ao longo de todo o processo de produção, embora o trabalho fosse feito em oficinas independentes. Já em épocas mais avançadas da utilização desse sistema, o capitalista comerciante era proprietário das ferramentas e máquinas e, freqüentemente, do prédio onde a produção tinha lugar. Ele contratava os trabalhadores para usar as ferramentas, fornecia-lhes a matéria-prima e recebia o produto acabado. $\mathrm{O}$ trabalhador já não vendia um produto acabado ao comerciante. Vendia somente seu próprio trabalho. O controle capitalista foi, então, estendido ao processo de produção. Ao mesmo tempo, foi criada uma força de trabalho que possuía pouco ou nenhum capital e nada tinha a vender, a não ser sua força de trabalho. Estas 
duas características marcam o surgimento do sistema econômico do capitalismo (HUNT, 1981, p.35).

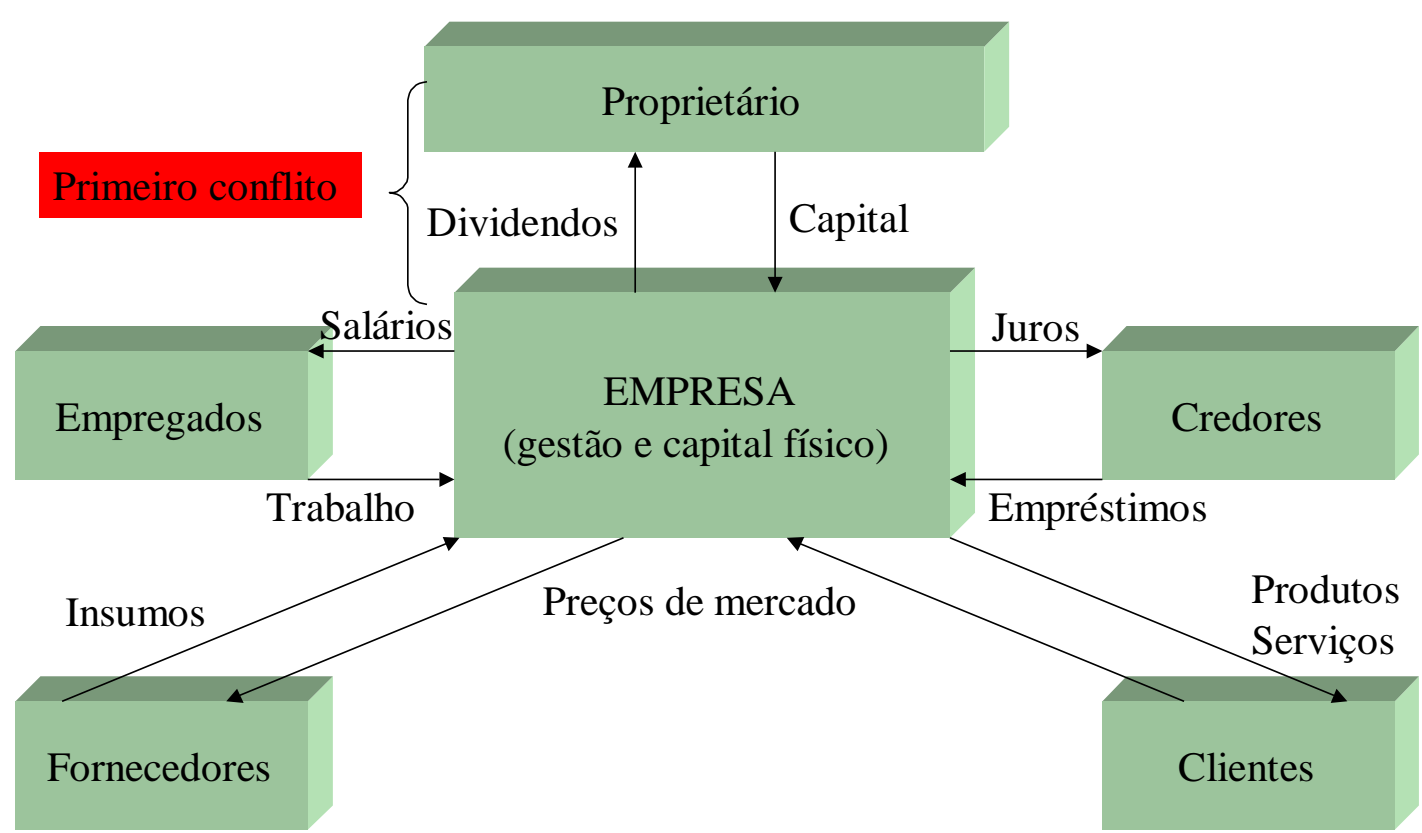

FIGURA 1- MODELO BÁSICO DE COMPANHIA COM PROPRIEDADE SEPARADA DA GESTÃO FONTE: BLAIR, 1995, P. 21.

NOTA: ADAPTADO PELO AUTOR.

Quando os capitalistas necessitaram contratar também o trabalho de gestão, surgiu o que denominamos primeiro conflito de Governança Corporativa (FIGURA 1), onde o proprietário do capital não é mais o gestor, terá alguém em seu lugar e desejará que esse alguém conduza os negócios como ele próprio conduziria.

Adam SMITH (1776, vol. 5, cap. 1) fez referência a esse conflito em sua obra An inquiry into the nature and causes of the wealth of nation: ${ }^{5}$

\footnotetext{
${ }^{5}$ Uma investigação sobre a natureza e as causas da riqueza das nações (tradução nossa).
} 
The directors of such companies [joint stock companies], however, being the managers rather of other people's money than of their own, it cannot well be expected that they should watch over it with the same anxious vigilance with which the partners in a private copartnery frequently watch over their own. Like the stewards of a rich man, they are apt to consider attention to small matters as not for their master's honour, and very easily give themselves a dispensation from having it. Negligence and profusion, therefore, must always prevail, more or less, in the management of the affairs of such a company. ${ }^{6}$

Nos Estados Unidos do século XIX, uma unidade de negócios típica era de propriedade de um indivíduo ou de pequenos grupos, gerida pelos proprietários ou por alguém por eles contratado e eram, principalmente, limitadas em tamanho pelos recursos de seus controladores. Essa forma de organização produtiva foi suplantada, em grande medida, por grandes agregações de dezenas ou mesmo centenas de milhares de trabalhadores e proprietários, com recursos de centenas de milhões de dólares, organizados como uma corporação com controle e gestão unificados. A American Telephone and Telegraph Company, com ativos da ordem de cinco bilhões de dólares, 454.000 empregados e 567.695 acionistas, é um exemplo desses impérios econômicos (BERLE; MEANS, 1932, p. 4).

Essas novas instituições significavam mais do que uma nova maneira de conduzir negócios na América. Representavam forte atração de capital que cada vez em maiores volumes era colocado sob controle de poucas pessoas, originando concentração de poder econômico. Ao mesmo tempo em que acontecia a concentração de poder econômico, crescia a dispersão de acionistas, causa do acúmulo de capital e da própria concentração desse poder econômico (GRÁFICO 1).

Em 1929, o maior acionista da Pennsylvania Railroad, da American

${ }^{6}$ Os diretores destas companhias [tipo de companhia que emite ações mas cujos sócios são responsáveis pela dívida da empresa, uma mistura de S.A. com sociedade de responsabilidade ilimitada], apesar de serem os administradores do dinheiro dos outros em vez de seu próprio, não se pode esperar que cuidem destes recursos com o mesmo cuidado com que um sócio numa sociedade privada cuidaria de seu dinheiro. Como os servos de um homem rico, eles estão aptos a prestar atenção a fatos pequenos mas não pela honra de seu senhor, e muito facilmente se dispensam de tê-la. Negligência e gastos excessivos, portanto, sempre prevalecerão, mais ou menos, na administração de companhias desse tipo (tradução nossa). 
Telephone and Telegraph Company ou da United States Steel Corporation, maiores empresas dos Estados Unidos à época, possuía menos de um por cento das ações da empresa. A soma dos vinte maiores acionistas de cada uma daquelas empresas totalizava 2,7\%, 4,0\% e 5,1\% respectivamente (BERLE; MEANS, 1932, p. 47).

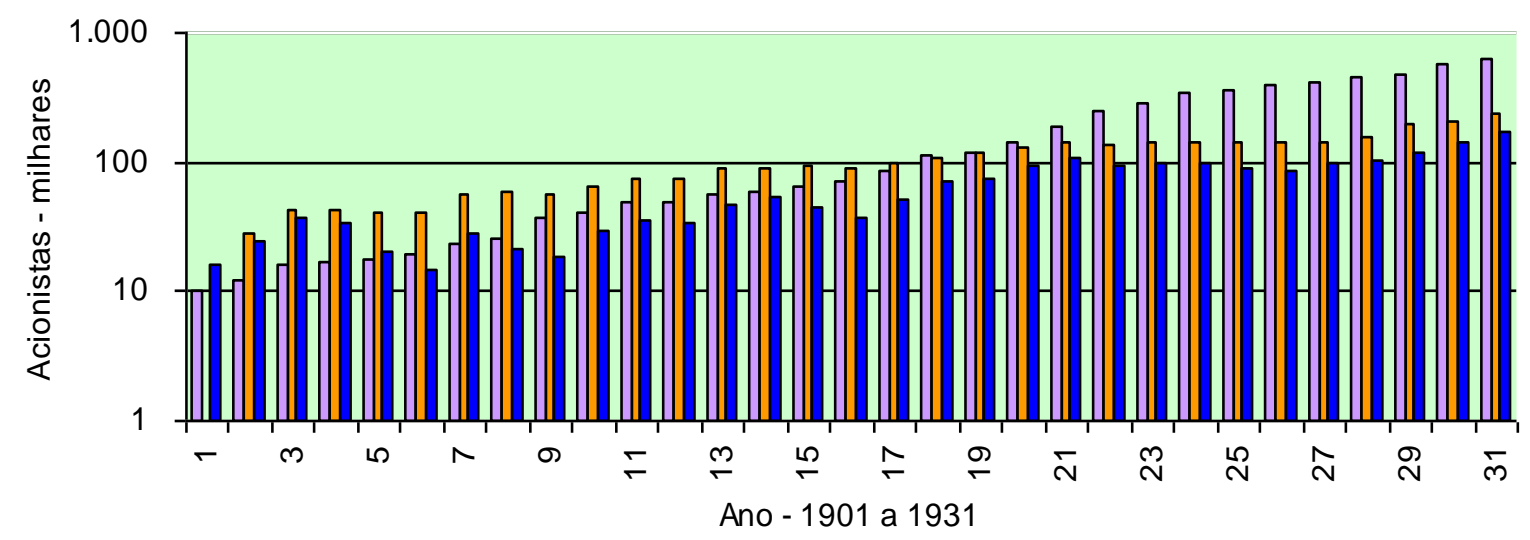

$\square$ American Telephone and Telegraph Co. $\quad \square$ Pennsylvania Railroad $\quad$ United States Steel Co.

GRÁFICO 1- ACIONISTAS DAS TRÊS MAIORES EMPRESAS AMERICANAS - 1929

FONTE: BERLE; MEANS, 1932, P. 52

NOTA: Adaptado pelo autor

À medida que crescia a dispersão de acionistas - proprietários do capital-, crescia também o desinteresse desses acionistas no controle da empresa. O controle efetivo sobre o capital dos acionistas, mais e mais recaia nas mãos dos gestores que pouco ou nenhum capital possuíam. Sobre essa dicotomia BERLE; MEANS (1932, p. 66) escreveram: 
"This separation of function forces us to recognize 'control' as something apart from ownership on the one hand and from management on the other. ... Control divorced from ownership is not, however, a familiar concept."

Num exame mais acurado, pode-se identificar três funções ou status com relação aos atores de uma empresa: pessoas que têm interesse na empresa, pessoas que têm controle da empresa (poder) e pessoas que agem na empresa. Uma mesma pessoa, no entanto, pode exercer as três funções ao mesmo tempo.

Antes da revolução industrial, o trabalhador-proprietário acumulava as três funções. Durante o século XIX, porém, os proprietários passaram a exercer as funções de interesse na empresa e controle da empresa, enquanto a ação na empresa ficava a cargo de gestores contratados.

O sistema de produção baseado em companhias abertas fez surgir mais uma alteração, separando as funções de interesse na empresa e controle da empresa. A posição de proprietário foi reduzida a um conjunto de interesses de fato e de direito, enquanto a posição de controle (poder) ficou com um pequeno grupo de gestores.

Nessas circunstâncias, cabe perguntar: existem justificativas para se afirmar que os gestores conduzirão a empresa segundo o interesse de seus proprietários? A resposta desta pergunta depende do grau de coincidência dos interesses dos acionistas e dos gestores. Em sendo eles divergentes, depende das condições políticas, econômicas e sociais estabelecidas. Os interesses dos acionistas de uma empresa são facilmente identificáveis: máximo lucro com mínimo risco, máxima distribuição de dividendos ou bonificação, preservado o interesse do negócio e a liberdade para negociar suas ações a preço justo. Quanto aos interesses dos gestores, no entanto, o que se pode afirmar? Que possuem também o interesse de maximização de lucro pessoal? Ou pode-se esperar que tenham objetivos como prestígio, poder ou

${ }^{7}$ Essa separação de funções nos força a reconhecer "controle" como alguma coisa à parte da propriedade por um lado, e do administrador, por outro lado. Controle divorciado de propriedade, no entanto, não é um conceito familiar (tradução nossa). 
gratificação pelo esforço profissional? Em se assumindo que a maximização de lucro pessoal é a força motivadora dos gestores, deve-se concluir que seus interesses são diferentes, e as vezes até opostos, aos interesses dos acionistas, como escreveram Berle; Means (1932, p. 114): "In the operation of the corporation, the controlling group even if they own a large block of stock, can serve their own pockets better by profiting at the expense of the company than by making profits for it."

Voltando a questão da pulverização do capital, observa-se que o estado de pulverização do capital das empresas entre acionistas é precedido de diferentes estágios de concentração desses capitais em poder de um acionista, ou de pequenos grupos, que podem ou não exercer as funções de gestor. Quando a segregação do capital culmina com o aparecimento de acionistas minoritários não gestores, surge um conflito potencial entre esses e os acionistas majoritários que caracteriza o que denominamos segundo conflito de Governança Corporativa, onde acionistas minoritários podem ser expropriados pelos majoritários (Figura 2).

Dentre as diversas formas de expropriação dos acionistas minoritários estão o nepotismo, isto é, a contratação de parentes com pagamento de altos salários sem que esses cargos sejam necessários e/ou tais pessoas possuam qualificação compatível com os valores percebidos, a execução de projetos de gosto pessoal dos gestores que não maximizam o retorno para os acionistas e o denominado tunneling que é a expropriação dos acionistas minoritários através de transferências de recursos e resultados entre empresas, para beneficiar o controlador, como por exemplo a venda de ativos sub-valorizados ou a prática de preços de transferências super-avaliados entre empresas do mesmo grupo, onde o controlador possui maior participação ou mesmo a totalidade das ações.

${ }^{8}$ No funcionamento da corporação, o grupo de controle, mesmo se detiver uma grande parcela das ações, pode agir melhor em proveito próprio, lucrando às expensas da companhia ao invés de produzir lucros para a corporação (tradução nossa). 


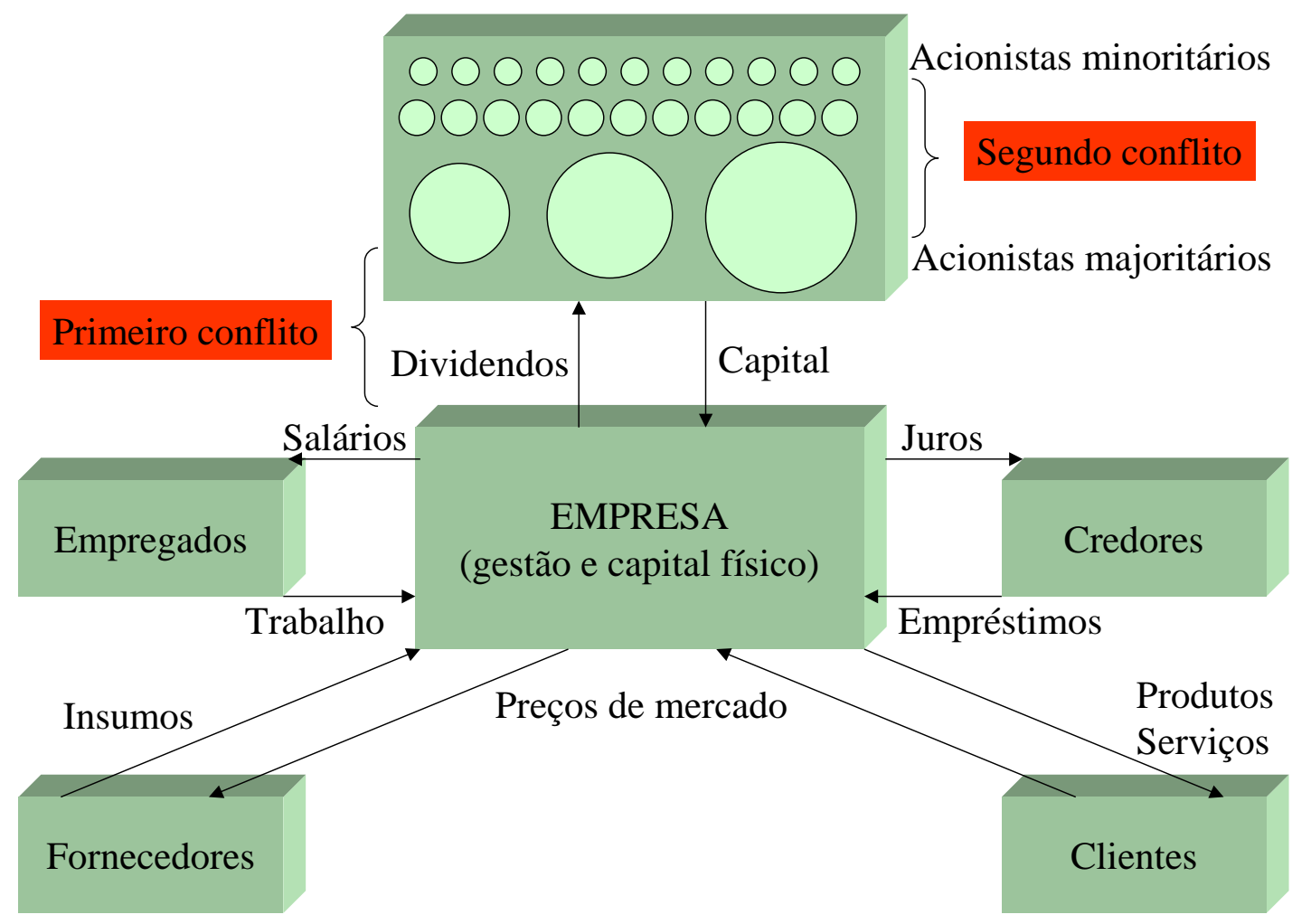

FIGURA 2 - MODELO BÁSICO DE COMPANHIA COM ACIONISTAS MINORITÁRIOS E MAJORITÁRIOS FONTE: BLAIR, 1995, P. 21.

NOTA: ADAPTADO PELO AUTOR.

La Porta et al. (1999, p. 4) referiram-se ao segundo conflito afirmando:

Expropriation can take a variety of forms. In some instances, the insiders [o autor denomina insiders os acionistas majoritários e os gestores] simply steal the profits. In other instances, the insiders sell the output, the assets, or the additional securities in the firm they control to another firm they own at below market prices. Such transfer pricing, asset stripping, and investor dilution, though often legal, have largely the same effect as theft. In still other instances, expropriation takes the form of diversion of corporate opportunities from the firm, installing possibly unqualified family members in managerial positions, or overpaying executives. In general, expropriation is related to the agency problem described by Jensen and Meckling (1976), who focus on the consumption of "perquisites" by managers and other types of empire building. It means that the insiders use the profits of the firm to benefit themselves rather than return the money to the outside investors. ${ }^{9}$

${ }^{9}$ Expropriação pode ocorrer sob diversas formas. Em alguns casos, os gestores e acionistas majoritários simplesmente roubam os lucros. Em outros casos, os gestores e acionistas majoritários vendem a produção, os ativos, ou valores mobiliários adicionais da firma que controlam para outra firma que possuam por preços abaixo do mercado. Essa transferência de preço, esvaziamento de 
Ainda sobre o segundo conflito de Governança Corporativa, Shleifer e Vishny (1997) observaram que nas grandes corporações da maioria dos países, o problema fundamental de Governança não é o primeiro conflito denotado por Berle e Means (1932), referente a separação da propriedade e do controle, mas sim as relações entre acionistas minoritários e acionistas majoritários controladores. Se considerarmos a Governança Corporativa com maior espectro, de forma a conter também outros provedores de capital e demais stakeholders, o fator ambiente institucional assume fundamental importância. Tanto acionistas minoritários, como demais provedores de capital e stakeholders não gozam da vantagem de soluções de conflitos no interior da firma. Williamson (1971) enfatiza que uma das razões da existência da firma é a capacidade de resolver conflitos, decorrentes de contratos incompletos, a menores custos, no seu interior, se comparados com as soluções institucionais do mercado. Portanto, esses atores da Governança Corporativa necessitam uma proteção institucional para solucionar conflitos ex post, decorrentes de contratos incompletos.

As questões relacionadas ao controle de acionistas majoritários, segundo Holderness (2002, p. 2), mereceram atenção dos pesquisadores, mormente, a partir de meados da década de 80 .

A teoria da firma, desenvolvida pelo matemático e economista Alfred Marshal (1842-1924) em seu livro The principles of economics ${ }^{10}$, preconiza a maximização de lucros por parte das empresas como objetivo dessas instituições (HUNT, 1981, p.321). No entanto, a firma tem um conjunto de partes interessadas que vai além de acionistas majoritários, minoritários e gestores.

ativos, e diluição do investimento, apesar de ser geralmente legal, tem o mesmo efeito de roubo. Ainda em outros casos, a expropriação toma a forma de desvio de oportunidades corporativas da firma, como por exemplo, instalando um membro possivelmente não qualificado da família em posições da alta administração, ou pagando salários acima do mercado a executivos. Em geral, a expropriação está relacionada ao "problema de agência", descrito por Jensen; Meckling (1976), que foca na consumação de privilégios por administradores e outras formas de construção de riqueza. Significa que os gestores e acionistas majoritários utilizam o lucro da firma em benefício próprio em vez de retornar o dinheiro para os investidores de fora (tradução nossa).

${ }^{10}$ Princípios de economia (tradução nossa). 
Os relacionamentos que podem ser percebidos na Figura 2, entre os vários interessados na empresa, (acionistas minoritários, acionistas majoritários, gestores, credores, fornecedores, funcionários e consumidores) e, ainda, instituições públicas e privadas, caracterizam a empresa como uma conexão de contratos formais e informais. A eficácia, eficiência e efetividade desse complexo conjunto de contratos, incompletos por natureza, implica questões a serem equacionadas ex ante e ex post aos fatos objeto desses contratos. Essas questões estão relacionadas à assimetria de informações entre as partes, à teoria da agência, à teoria da firma e ao arcabouço legal e institucional onde a empresa está inserida.

O cumprimento desses contratos e as soluções de possíveis conflitos são levados a cabo por um conjunto de fatores que a literatura pertinente tem denominado mecanismos de Governança Corporativa. Integram esse conjunto, os arranjos estruturais e operacionais das empresas como: os conselhos de administração, os conselhos fiscais, as auditorias independentes, as auditorias internas, os programas de incentivos, o monitoramento, o mercado de gestores, o mercado de membros de conselhos de administração e conselhos fiscais, o mercado de controle das empresas (takeovers) e o ativismo dos investidores institucionais.

O presente estudo foi motivado pelo interesse em averiguar, empiricamente, a seguinte questão:

Que mecanismos de Governança Corporativa estão relacionados com a performance econômica das empresas brasileiras integrantes do IBX - Índice Brasil da Bolsa de Valores de São Paulo ${ }^{11}$ ?

${ }^{11}$ O Índice Brasil - IBX é um índice de preços que mede o retorno de uma carteira teórica composta por 100 ações selecionadas entre as mais negociadas na Bolsa de Valores de São Paulo - BOVESPA, em termos de número de negócios e volume financeiro, ponderadas no índice pelo seu respectivo número de ações disponíveis à negociação no mercado. Arbitrariamente fixado em 1.000 pontos para a data de 28 de dezembro de 1995, o IBX - Índice Brasil teve sua divulgação iniciada em 02 de janeiro de 1997. 
Diversos estudos têm objetivado identificar relações de mecanismos de Governança Corporativa com performance econômica das empresas (AGRAWAL; MANDELKER, 1990; AGRAWAL; KNOEBER, 1996; BARNHART; MARR; ROSENSTEIN, 1994; BARNHART; ROSENSTEIN, 1998; BARKEMA, 1998; VAFEAS, 1999; DALTON, 1999; BOHREN; ODEGAARD, 2001; MATHIESEN, 2002). Em geral, os pesquisadores testam um ou dois mecanismos de Governança e medidas de performance econômica baseadas em mercado e na contabilidade. Dos autores citados, Bohren; Odegaard (2001) constituem exceção, por terem efetuado estudos mais completos, envolvendo variáveis de diversos mecanismos de Governança Corporativa.

\subsection{PROPÓSITOS DO ESTUDO}

De forma geral, o propósito deste estudo é averiguar evidências empíricas da relação entre variáveis que caracterizam mecanismos de Governança Corporativa e medidas de performance econômica das empresas listadas na Bolsa de Valores de São Paulo que integraram o índice IBX - Índice Brasil nos últimos trimestres dos anos de 2000 e 2001.

Mais especificamente, busca-se investigar a existência e a natureza das relações entre medidas de performance econômica daquelas empresas e:

- A concentração de propriedade de ações em um número de 1 a 5 acionistas;

- As características dos conselhos de administração - número de integrantes, proporção de membros que são internos à empresa e o exercício duplo da presidência do conselho de administração e da diretoria executiva; 
- A proporção de ações do capital das empresas que dá direito a voto;

- A remuneração total da diretoria executiva das empresas;

- A existência de programas de incentivos aos executivos baseados em lucros;

- O uso de recursos de terceiros;

- A política de distribuição de dividendos;

- A contratação de grandes empresas de auditoria independente.

\subsection{JUSTIFICATIVAS DO ESTUDO}

O caráter emergente do tema, a escassez de estudos empíricos, em especial na área da contabilidade, e o público potencialmente interessado no assunto, são fatores que justificam este estudo.

Pode-se acrescentar, também, como razões para se trabalhar com esta abordagem de pesquisa, o fato de sermos a oitava economia do mundo ${ }^{12}$, com grande potencial de crescimento e desenvolvimento econômico, portanto, com necessidade de atrair investimento com recursos oriundos da poupança nacional e internacional. Recursos esses cujos detentores valorizam e exigem práticas de Governança Corporativa ao nível dos mercados de países como Estados Unidos e Inglaterra. Desta forma, é importante levar a efeito testes empíricos que possam elucidar a eficácia, ou não, dos mecanismos de Governança das empresas brasileiras.

${ }^{12}$ Informação contida no site do programa Avança Brasil do Governo Brasileiro: http://www. 


\subsection{DELIMITAÇÃO DO ESTUDO}

Este estudo restringe-se ao conjunto de empresas brasileiras, não financeiras, que integraram o Índice Brasil - IBX, da Bolsa de Valores de São Paulo, no período setembro a dezembro do ano 2000 ou no período de setembro a dezembro do ano 2001. Os dados são referentes aos anos de 1997 a 2001.

No que se refere aos mecanismos de Governança Corporativa, o trabalho não abrange conselhos fiscais, comitês de auditoria, propriedade de ações de integrantes do conselho de administração e da diretoria executiva, tempo de permanência do diretor presidente, fusões e aquisições e auditoria interna.

Os limites deste estudo não abrangem mecanismos (ex post) de proteção a acionistas minoritários, a demais provedores de capital e a stakeholders em geral, que são fortemente baseados no arcabouço institucional, constituído por iniciativas públicas, como Lei das sociedades anônimas e Lei de falências e concordatas e por iniciativas privadas, como os códigos de éticas das empresas e os códigos de melhores práticas de Governança Corporativa.

\subsection{HIPÓTESES}

As hipóteses do estudo são apresentadas a seguir para sua visualização conjunta. No entanto, são apresentadas novamente com o respectivo embasamento teórico no capítulo II

H1: A concentração de propriedade das empresas está positivamente relacionada com a performance econômica.

H2: A performance econômica das empresas está negativamente relacionada com o número de integrantes do conselho de administração, com o exercício duplo da 
presidência da diretoria executiva e do conselho de administração pela mesma pessoa e com o número de integrantes do conselho de administração que são internos à empresa.

H3: A performance econômica das empresas está positivamente relacionada com o percentual do capital lastreado em ações ordinárias nominativas.

H4: A performance econômica das empresas está positivamente relacionada com a remuneração total da diretoria executiva e com a existência de programa de participação nos lucros.

H5: A performance econômica das empresas está positivamente relacionada com o uso de capital de terceiros e com a política de dividendos praticada.

H6: Companhias auditadas por empresas integrantes das chamadas BIG $5^{13}$ tendem a ter melhor performances econômica.

${ }^{13}$ Grupo de empresas de auditoria independente formado por Arthur Andersen, Ernst \& Young, Price WaterHouse Coopers, Deloitte Touche Tohmatsu e KPMG. No período do estudo Arthur Andersen fazia parte do grupo de grandes empresas de auditoria independente. 


\section{Capítulo II}

\section{FUNDAMENTAÇÃO TEÓRICA}

\subsection{INTRODUÇÃO}

O tema Governança Corporativa pode ser abordado sob uma ótica mais restrita, tendo como foco o conflito entre proprietários e gestores, passando por uma abordagem intermediária que inclui também os demais financiadores da empresa como debtholders ${ }^{14}$ e bancos, até uma concepção mais ampla que incorpora todos os que possuem algum interesse na empresa (stakeholders).

Este estudo não tem a abrangência maior que inclui todos os stakeholder, mas considera aspectos que extrapolam a relação entre proprietários e gestores por considerar, também, os demais financiadores da empresa. A relação proprietários e gestores tem como suporte teórico, em especial, a teoria da agência, mormente o problema principal-agente. A relação gestores e demais financiadores não constitui um problema principal-agente, mas uma relação contratual sujeita às imperfeições emanadas do caráter incompleto dos contratos, da existência de informação assimétrica e todas as implicações do que Williamson (1975) denomina de custos de transações econômicas.

Para melhor entendimento do tema, a base teórica do estudo será constituída

\footnotetext{
${ }^{14}$ Investidores titulares de título representativo de dívida de uma empresa.
} 
dos tópicos: Informação Assimétrica, Problema da Relação Principal-Agente, Firma, Governança Corporativa, Governança Corporativa e Contabilidade, e Evidências Empíricas de Mecanismos de Governança Corporativa e hipóteses subjacentes.

\subsection{INFORMAÇÃO ASSIMÉTRICA}

A informação assimétrica é uma característica de muitas situações de negócios e mesmo do cotidiano das pessoas. Freqüentemente, o vendedor de um determinado produto conhece mais a respeito de sua qualidade do que o comprador. Um médico sabe mais sobre seus conhecimentos e possibilidades de tratar um paciente do que o próprio paciente, ainda que este possa ter procurado informar-se sobre sua formação e experiência. Os trabalhadores geralmente possuem uma melhor destreza e habilidade do que seus empregadores. Os gestores que possuem ações da própria empresa sabem mais sobre suas condições econômicas e financeiras do que os demais acionistas, não obstante a publicação de demonstrações financeiras e fatos relevantes publicados. E os administradores de empresas sabem mais a respeito dos custos, da posição competitiva e das oportunidades de investimento da empresa do que os seus proprietários.

Akerlof (1970), que dividiu o prêmio Nobel de economia em 2001 com Spence e Stiglitz por seus trabalhos sobre informação assimétrica, em seu artigo The market for lemons: quality uncertainty and the market mechanism, ${ }^{15}$ evidencia as implicações da assimetria de informações nos mercados de automóveis usados, de seguros, de crédito e de empregos. A seguir comenta-se essas implicações em cada um dos mercados.

- Mercados de Automóveis Usados

15 O mercado de limões: incerteza de qualidade e o mecanismo de mercado (tradução nossa). 
Imagine-se alguém que tenha comprado um automóvel por \$20.000,00 e, após tê-lo utilizado por apenas um mês, necessite mudar de país e decida vender o automóvel. Quanto poderia esperar obter por ele? Certamente terá um deságio alto, talvez $20 \%$ ou $15 \%$. Mas por que o mero fato de um automóvel ser de segunda mão reduz tanto o seu valor? Se pensarmos sob a ótica do comprador, suscitam questões como: Por que motivo este carro está à venda? Será verdadeira a história de mudança de país, ou há alguma coisa errada com este automóvel? O comprador poderia mandar examinar o automóvel por um mecânico de sua confiança, mas o proprietário/vendedor possui experiência com este automóvel e, portanto, ainda assim estaria sabendo mais a respeito dele. Além disso, o simples fato do automóvel estar à venda suscita que ele realmente tenha qualidade duvidosa.

Os automóveis usados são vendidos por muito menos do que os automóveis novos, ainda que aqueles tenham excelente qualidade, porque existe informação assimétrica a respeito da qualidade desses automóveis.

Pindyck; Rubenfeld (1994, p. 805), observam que a informação assimétrica pode resultar em desvio de eficiência do mercado. Num mundo ideal, com mercados em pleno funcionamento, os consumidores teriam a possibilidade de poder escolher entre automóveis de baixa qualidade e de alta qualidade. Alguns escolheriam os automóveis de baixa qualidade devido ao fato de custarem menos, enquanto outros prefeririam pagar mais e obter automóveis de alta qualidade. Infelizmente, no mundo real, os consumidores não podem facilmente determinar a qualidade de um automóvel usado antes que o tenham adquirido, de tal forma que o preço dos automóveis usados cai, e os de alta qualidade são reduzidos ou eliminados deste mercado.

- Mercado de Seguros

Por que as pessoas da terceira idade têm dificuldades para adquirir 
seguro saúde, mesmo pagando um alto preço por tal seguro? As pessoas mais velhas têm riscos muito mais elevados de vir a ter doenças sérias, contudo, por que o preço do seguro saúde não poderia ser majorado de modo que pudesse refletir tais riscos mais altos? A razão é a informação assimétrica. As pessoas que adquirem seguro saúde sabem muito mais a respeito do seu próprio estado geral de saúde do que qualquer companhia seguradora poderia ter esperança de saber, mesmo que insistisse na realização de exames médicos. Por conseguinte, ocorre o que se convencionou chamar "seleção adversa". Pelo fato de pessoas com problemas de saúde serem mais propensas a adquirir o seguro saúde, a proporção de indivíduos deste tipo aumenta no grupo de indivíduos segurados. Tal fato faz com que o preço do seguro saúde aumente, induzindo ainda mais a proporção de pessoas não-sadias, o que faz com que o preço do seguro saúde aumente ainda mais, e assim por diante, até que praticamente todos os indivíduos que estejam dispostos a adquirir seguro saúde sejam nãosadios. Neste ponto, a venda do seguro saúde torna-se não lucrativa (PINDYCK; RUBENFELD ,1994, p. 806).

\section{- Mercado de Crédito}

Ao fazer-se uso de um cartão de crédito ou um pagamento à vista baseado em um limite de cheque especial, por exemplo, está-se tomando um empréstimo desprovido de qualquer garantia de pagamento. As empresas de cartões de crédito e os bancos ganham dinheiro cobrando juros sobre saldos devedores. Esses juros são sempre muito altos. Mas de que forma uma empresa de cartão de crédito ou um banco poderá distinguir entre devedores que pagam suas dívidas e devedores que não pagam ou ficam inadimplentes por longos períodos de tempo? Com certeza, os próprios devedores sabem mais acerca de suas possibilidades de pagar do que a empresa de cartões de crédito ou o banco. Novamente, surge o problema das mercadorias de 
qualidade duvidosa (lemons), aludido por Akerlof (1970). As empresas de cartões de crédito e os bancos devem cobrar a mesma taxa de juros (alta) de "todos" os devedores, o que acaba atraindo mais devedores de baixa qualidade, exigindo uma nova elevação da taxa de juro e um aumento ainda maior do número de devedores de baixa qualidade, o que novamente força um aumento da taxa de juro, e assim por diante. As classificações de risco de crédito são uma tentativa das instituições financeiras de discriminar grupos de tomadores de recursos, reduzindo a informação assimétrica, contudo, sempre tomadores de recursos saberão mais sobre suas possibilidades de fazer retornar os recursos às instituições financeiras do que estas.

- Mercado de Empregos

No mercado de trabalho, a informação assimétrica entre vendedores de mão-de-obra (empregados) e compradores (empresários) também está presente. Um empregado sabe muito mais sobre seus conhecimentos e habilidades para desempenhar determinadas atividades do que o empregador que está necessitando de alguém para tal. Spence (1973), em seu artigo Job market signaling ${ }^{16}$, desenvolveu o conceito de sinalização de mercado mostrando que, em alguns mercados, os vendedores enviam sinais aos compradores, transmitindo informações a respeito da qualidade de um determinado produto. No mercado de trabalho esses sinais podem ser o modo de vestir, a expressão oral e corporal, a formação acadêmica em estabelecimentos de ensino de reconhecimento comprovado, etc. Alguns sinais são fracos, porque podem ser emitidos por qualquer pessoa, como por exemplo o modo de vestir. Qualquer pessoa pode vestir-me adequadamente para uma entrevista de seleção de candidatos a uma determinada vaga e isso não implica, necessariamente, estar apta para desempenhar as funções

\footnotetext{
${ }^{16}$ Sinalizando no mercado de trabalho (tradução nossa)
} 
requeridas pelo cargo objeto da seleção. Outros sinais são fortes, como por exemplo a formação acadêmica em estabelecimento de renome. Um sinal forte é um sinal que deve ser mais facilmente transmitido por pessoas de alta produtividade (capacidade) do que por pessoas de baixa produtividade (capacidade), de tal modo que seja mais provavelmente dado pelos indivíduos de alta produtividade.

Outros mercados, além do mercado de trabalho, podem também emitir sinais sobre a qualidade de seus produtos objetivando reduzir a assimetria de informações entre vendedores e compradores. Se os consumidores não puderem distinguir entre produtos de qualidade boa e ruim, os produtos de melhor qualidade não podem ser vendidos por melhores preços. Assim, empresas que fabricam artigos mais confiáveis e de qualidade superior estarão interessadas em trazer tal fato ao conhecimento dos consumidores de maneira convincente. As garantias e os certificados de qualidade são amplamente utilizados com esse objetivo. Produtos de baixa qualidade não são passíveis de certificações de qualidade e nem permitiriam a seus fabricantes oferecerem garantias, já que produtos de qualidade inferior tendem a demandar mais serviços de assistência.

A informação assimétrica explica a razão de muitos arranjos institucionais que ocorrem na nossa sociedade. Ela nos ajuda a compreender o porquê das empresas automobilísticas oferecem garantias para peças e serviços de automóveis novos, de os acionistas necessitarem monitorar o comportamento dos administradores de empresas, de empresas contratarem empresas de auditorias independentes mais caras e renomadas, de empresas começarem a preocupar-se com balanço social e mesmo, de empresas estarem dando importância às chamadas boas práticas de Governança Corporativa, tratado mais adiante, no item 5 deste capítulo. As razões encontram guarida na necessidade de emitir sinais aos mercados para minorar a assimetria de informação. 


\subsection{PROBLEMA DA RELAÇÃO PRINCIPAL-AGENTE}

A teoria da agência trata de problemas resultantes dos conflitos de interesses que emergem numa relação de contrato, formal ou informal, quando as partes contratantes possuem informação assimétrica ou há presença de incerteza. O principal objetivo dessa teoria é explicar como as partes contratantes efetuam seus contratos de forma a minimizar os custos associados aos problemas de informação assimétrica e incerteza. A teoria da agência também ressalta a existência do mercado e de mecanismos institucionais capazes de completar os contratos para reduzir aqueles problemas.

Diz-se que há uma relação de agência quando as ações de uma pessoa afetam seu próprio bem estar e o bem estar de outra, mediante uma relação contratual explícita ou implícita. A pessoa que se responsabiliza pelas ações é o agente e a pessoa cujo bem estar é afetado é chamada principal. Um caso típico de relação de agência é o que existe entre o empregador e o empregado, sendo este agente e aquele principal.

Numa relação de agência, o principal deseja que o agente aja de acordo com seus interesses. No entanto, o agente tem seus próprios interesses e esses não coincidem com os interesses do principal.

Jensen; Meckling (1976, p. 5) escreveram:

We define an agency relationship as a contract under which one or more persons (the principal(s)) engage another person (the agent) to perform some service on their behalf which involves delegating some decision making authority to the agent. If both parties to the relationships are utility maximizers, there is a good reason to believe that the agent will not always act in the best interests of the principal. ${ }^{17}$

${ }^{17}$ Nós definimos uma relação de agência como um contrato sob o qual uma ou mais pessoas (o principal) contrata uma outra pessoa (o agente) para executar algum serviço em nome do principal, envolvendo a delegação de algum poder de decisão ao agente. Se ambas as partes da relação são maximizadores de utilidade, existe uma boa razão para acreditar que o agente nem sempre agirá de acordo com os melhores interesses do principal (tradução nossa). 
A teoria da agência está relacionada ao que se denominou neste estudo de primeiro conflito de Governança Corporativa. Esse conflito decorre da separação da propriedade e gestão da firma. Os proprietários representam o principal e os gestores os agentes, e estabelecem uma relação de principal-agente. Nessas circunstâncias, os gestores passam a tomar decisões que visam maximizar suas utilidades pessoais, em detrimento do que desejariam os proprietários, ou seja, a maximização de suas riquezas.

De acordo com Tirole (2001), o problema da separação propriedade-gestão manifesta-se quando os gestores deixam a desejar em suas atividades, (comprometendo-se com atividades externas à empresa, aceitando/promovendo quadro de apoio em excesso, ignorando controles internos), quando acumulam privilégios excessivos (construindo impérios não rentáveis, pagando preços inflacionados à entidades afiliadas - das quais são acionistas majoritários ou têm interesses particulares-, extrapolando benefícios) e quando se entrincheiram, investindo em indústrias em declínio, porque é onde possuem competência, diversificando produtos para reduzir risco não sistemático e resistindo a ação de takeovers $^{18}$ que ameaçam suas posições. (BOHREN; ODEGAARD, 2001 p. 4)

As divergências de interesses, decorrentes do problema da separação propriedade-gestão, podem ser atenuadas pelo proprietário estabelecendo incentivos apropriados para o agente e despendendo recursos para monitorá-lo. O agente, por seu turno, em algumas situações, desejará ou precisará despender recursos (bonding costs) para garantir que ele não incorrerá em certas ações que podem desagradar o proprietário ou mesmo para assegurar-se de que, se incorrer naquelas ações, o proprietário será compensado. Tanto proprietário quanto agente incorrerão em custos

${ }^{18}$ Takeovers são processos através dos quais uma empresa adquire a outra. Geralmente um empresa de maior porte interessa-se por outra empresa e faz uma oferta de aquisição. Quando há concordância entre as empresas o processo é reconhecido como amigável. Quando, no entanto, a administração da empresa objeto da aquisição resiste à fusão, em geral receosa de perder seus empregos, a empresa compradora faz uma oferta irrecusável a seus acionistas e o processo é denominado hostil (Brigham; Gapenski; Ehrhardt, 2001, p.950) 
(monitoring costs ${ }^{19} \mathrm{e}$ bonding costs) e, ainda assim, algumas das decisões do agente serão diferentes daquelas que maximizariam o valor da empresa. A redução da riqueza do proprietário, decorrente dessas decisões, representa, também, custo da relação de agência e é referido como perda residual (residual loss). O somatório de monitoring costs, bonding costs e residual loss é denominado agency costs ${ }^{20}(\mathrm{JENSEN}$; MECKLING, 1976, p. 313). Os conflitos de interesses entre acionistas e os gestores exigem mecanismos de Governança Corporativa para minimizar os custos de agência. Esses mecanismos são baseados no monitoramento e no incentivo dos gestores como: bônus, opções de compra sobre ações, conselho de administração e conselho físcal, auditoria independente, etc.

Então, o problema do principal é estabelecer contratos que induzam o agente a comprometer-se com a maximização do bem estar do principal.

Entretanto, ambos, principal e agente, defrontam-se com a incerteza. Essa incerteza aparece de várias formas: Primeiro, o principal depara-se com a incerteza sobre o comportamento do agente e/ou sobre as informações que este detém e que aquele desconhece, ou seja, a informação assimétrica. Segundo, a incerteza também está presente nos resultados do próprio agente. É o componente aleatório presente nos resultados do agente em decorrência de seus esforços.

Esse estado de incerteza, que existe entre o agente e o principal, impõe certas dificuldades que complicam a elaboração dos contratos. Essas dificuldades manifestam-se como risco moral (moral hazard or hidden actions) e seleção adversa (adverse selection or hidden information).

\footnotetext{
${ }^{19}$ Custo de monitoramento/acompanhamento (tradução nossa)

${ }^{20}$ Custos de agência (tradução nossa).
} 


\subsubsection{Risco moral}

Um problema de risco moral surge quando o principal não pode observar as ações do agente. Ou porque o monitoramento das ações deste é dispendioso, ou porque, mesmo despendendo recursos, não é possível fazer inferências precisas sobre as ações mediante observação dos resultados. Os próprios resultados não são determinados apenas pelas ações do agente, há um componente randômico e inesperado que também os influencia.

Portanto, o principal depara-se com duas dificuldades: Primeiro, ele não pode estabelecer contratos baseados na observação das ações do agente, porque o custo de monitoramento das ações do agente é geralmente proibitivo. Segundo, o principal não pode predizer inteiramente os resultados no contrato por duas razões: a) há incerteza quanto a relação de causalidade das ações do agente sobre os resultados, isto é, o principal não tem certeza de que os resultados são conseqüências das ações do agente; b) mesmo se o principal pudesse estabelecer o contrato baseado em suas observações de monitoramento, o agente não assinaria tal contrato por ser neutro a risco. Essa situação impede o principal de estabelecer contratos completos, o que deixa o agente com alguma liberdade em relação às suas ações e às causas inesperadas que afetam seus resultados. Em outras palavras, contratos incompletos não conseguem consignar inteiramente as consequiências das ações do agente. A teoria da agência identifica também outras causas para explicar o porquê dos contratos serem incompletos ${ }^{21}$.

Contratos incompletos, por conseguinte, permitem que o agente tenha decisões e ações pensadas visando maximizar sua utilidade que podem prejudicar os

\footnotetext{
${ }^{21}$ Veja-se Schmitz (2001)
} 
interesses do principal. Kotowitz ${ }^{22}$, citado por Padilla (2001), define risco moral como ações de agentes econômicos para maximizar suas próprias utilidades em detrimento de outros, em situações em que não recaem sobre eles todas as conseqüências.

O problema do risco moral tem sido identificado em vários tipos de relações contratuais. Quando uma pessoa está segurada, por exemplo, seu comportamento pode ser alterado de forma a influenciar a probabilidade ou magnitude do evento que é fato gerador do pagamento. O segurado pode passar a visitar o médico com mais freqüência, sem que haja necessidade para tal, gerando um volume maior de despesas para a companhia seguradora. Da mesma forma, uma pessoa com seguro total de um veículo poderá dirigir de forma mais displicente ocasionando uma probabilidade maior de acidentes e, conseqüentemente, onerando desnecessariamente a seguradora. No caso de companhias seguradoras, o risco moral poderá exigir o aumento de prêmios de seguro ou até mesmo a suspensão de uma modalidade.

\subsubsection{Seleção adversa}

Um problema de seleção adversa surge quando o agente possui informações que podem ser úteis para suas decisões e ações e são desconhecidas pelo principal. Assim, o principal não pode saber se o agente atua de forma apropriada segundo os interesses do principal. É, essencialmente, o problema da informação assimétrica discutido por Akerlof (1970).

Acionistas, por exemplo, podem ser vítimas da seleção adversa entre empresas. Em um setor novo, como por exemplo o de empresas de alta tecnologia, as empresas podem parecer muito similares aos olhos do investidor desinformado, enquanto alguns insiders podem possuir melhores informações sobre a rentabilidade

${ }^{22}$ Kotowitz, Y. Moral Hazard, in John Eatwell, Murray Milgate, and Peter Newman (Eds), The New Palgrave - A Dictionary of Economics. London: The Macmillan Press, 1987. p. 549551. 
futura dessas. Empresas com rentabilidade abaixo da média serão, então, sobrevalorizadas no mercado de ações, onde, evidentemente, investidores menos informados negociam. Essas empresas preferirão financiar seus novos projetos pela emissão de ações, ao invés de tomar crédito ou emitir papéis de dívida, pois estão valorizadas além do preço justo. Por outro lado, empresas com rentabilidade acima da média estarão com seus papéis subvalorizados no mercado e avaliarão que financiar novos projetos pela emissão de novas ações não é vantajoso para a empresa, preferindo tomar crédito ou emitir papéis de dívida. Dessa forma, sob informação assimétrica entre investidores e os controladores da empresa (insiders), as empresas de baixa qualidade, isto é com perspectiva de menor rentabilidade, tenderão a crescer mais rapidamente do que as de melhor qualidade, ou seja, com perspectiva de maior rentabilidade, acarretando um gradual domínio do mercado por empresas de baixa qualidade (os denominados lemons por Akerlof (1970)).

A redução do problema da seleção adversa pode ser viabilizada pelo mecanismo de sinalização do mercado tratado por Spence (1973), discutido em tópico precedente, ou por mecanismos de discriminação (screening). A discriminação pode ser efetuada pela observação de características que possam distinguir agentes menos propensos a seleção adversa. Esse processo é utilizado por bancos, por exemplo, na concessão de créditos, mediante a análise de dados das características dos tomadores para selecionar aqueles que tenham condições e propósito de fazer retornar os capitais. Dessa forma os bancos discriminam dentre os tomadores de crédito, separando aqueles que poderiam estar dispostos a tomar crédito, mesmo quando as taxas fossem muito elevadas, mas não teriam condições ou propósito de honrar os compromissos firmados. 


\subsection{FIRMA}

A teoria da firma ou, de forma mais abrangente, das organizações, é sem dúvida um dos assuntos mais importantes e de rápido crescimento na economia contemporânea ( FOSS, 1997).

Depois de um longo esquecimento do trabalho de Coase (1937) sobre a natureza da firma, surgem, ao final dos anos 60 e nos anos 70, diversos autores que retomam o tema e recomeçam uma discussão mais atenta sobre a firma, não encontrada na teoria econômica neoclássica. Williamson (1971, 1973, 1975, 1981, 1987, 2000, 2001), Alchian; Demsetz (1972, 1973), Demsetz (1967, 1968, 1985, 1997, 2001), Fama (1980, 1983a, 1983b), Jensen; Fama (1985) e Jensen; Meckling (1976) são os principais representantes desta linha principal de pensamento que não considera a firma uma entidade hermética com o propósito de alocar recursos eficientemente e maximizar lucros como preconiza a teoria econômica neoclássica.

\subsubsection{Firma na teoria econômica neoclássica}

Juntamente com as famílias, as firmas são uma parte crucial na fundamentação da teoria econômica. A demanda e a oferta de bens e serviços têm suas origens nessas duas entidades. No entanto, a firma na teoria neoclássica é tratada de forma hermética, não há preocupação, por exemplo, sobre o porquê de sua existência, suas fronteiras em relação ao mercado e suas formas de organização interna.

A análise da firma, feita por Marshall (1842-1924), era uma parte integrante de sua análise sobre a determinação dos preços (HUNT, 1981, p.321) e pode ser melhor caracterizada como teoria de mercado em que a firma desempenha papel importante, mas não pode ser vista como teoria da firma propriamente. 
Ferguson (1994), estabelecendo o objetivo da Parte III de seu livro "A teoria da firma e a organização do mercado" escreve: "O objetivo da parte III é descobrir como as decisões de preço e produção do empresário individual e a estrutura do mercado determinam conjuntamente a alocação de recursos”. E seguem-se os títulos "A teoria do preço nos mercados de concorrência perfeita", "A teoria dos preços sob o monopólio puro, "A teoria dos preços sob a concorrência monopolística" e "A teoria do preço nos mercados de oligopólio". Como se vê, é uma abordagem de preço e mercado sob o paradigma da alocação de recursos, não havendo tratamento da firma em si.

Mas-Colell; Whinston; Green (1995, p. 127), no capítulo 5 de seu livro Microeconomic Theory, iniciam a apresentação dos estudos do lado da oferta da economia considerando a firma uma "caixa-preta". Em suas palavras: "The firm is viewed merely as a 'black box', able to transform inputs into outputs" ${ }^{23}$. Obviamente não se trata de menosprezar a importância da firma no contexto da teoria microeconômica, mas ilustra o fato de que o caráter endógeno da firma não é tratado na teoria microeconômica.

A firma é também tratada na teoria neoclássica sob as premissas de mercado aberto, isto é, os mercados operam livremente, sem intervenção externa, como por exemplo intervenção governamental, e de maximização de lucro, ou seja, os empresários tentam maximizar o lucro (FERGUSON, 1994, p 274). Embora não esteja explícito, pode-se inferir que o objetivo da firma é maximizar lucro. Quando a firma era gerida essencialmente por empresários proprietários, a premissa poderia parecer razoável, mas com a separação da propriedade da gestão, assunto que interessa diretamente os estudos sobre Governança Corporativa, seria essa premissa ainda válida?

No tópico a seguir examina-se a firma no contexto da na nova economia

${ }^{23}$ A firma é vista meramente como uma "caixa preta", capaz de transformar insumos em produtos (tradução nossa). 
institucional.

\subsubsection{Firma na nova economia institucional ${ }^{24}$}

A chamada nova econômica institucional é uma iniciativa interdisciplinar que combina economia, direito, teoria organizacional, ciência política, sociologia e antropologia para entender as instituições sociais, políticas e comerciais. Seu foco, no entanto, é economia e seus objetivos são explicar o que são as instituições, como elas surgem, a que propósitos servem, como mudam ou poderiam ser mudadas se isso fosse necessário ou recomendável (KLEIN, 1999).

O ambiente institucional assume grande importância na nova economia institucional. Klein (1999), citando North (1990, p. 3-4), observa que as instituições reduzem a incerteza provendo uma estrutura para a vida do dia-a-dia ou no jargão dos economistas:

Institutions define and limit the set of choices of individuals. Institutional constraints include both what individuals are prohibited from doing and, sometimes, under what conditions some individuals are permitted to undertake certain activities. [...] They are perfectly analogous to the rules of the game in a competitive team sport. ${ }^{25}$

As instituições são as regras do jogo na sociedade, influenciam o comportamento humano e a interação entre as pessoas, permitem a realização de contratos, reduzindo as incertezas de seus cumprimentos. São, portanto, fundamentais para a atividade econômica de um país, com forte influência sobre o desenvolvimento dos mercados, especialmente o mercado de capitais e de crédito.

${ }^{24}$ A literatura em inglês utiliza a sigla NIE denotando New Institutional Economy.

${ }^{25}$ Instituições definem e limitam o conjunto de alternativas dos indivíduos. As regras institucionais incluem os que os indivíduos estão proibidos de fazer e, em alguns casos, sob que condições alguns indivíduos podem realizar certas atividades. [...] Elas são perfeitamente análogas às regras em um esporte competitivo (tradução nossa). 
Voigt; Engerer (2001, p. 132) definem cinco tipos de instituições, classificadas de acordo com o tipo de regra e o tipo de coerção (enforcement) atinente a cada um. Os tipos de regras são convenções, códigos de ética, costumes, regras privadas e leis estatais; enquanto as coerções correspondentes são a auto-regulação, o auto-comprometimento do autor, o controle informal da sociedade, o controle privado organizado e o sistema estatal organizado.

A firma está inserida no contexto das cinco instituições. Submete-se a convenções, costumes e regras privadas no relacionamento com seus fornecedores e consumidores, subjuga-se às leis estatais e possui seu código de ética formal ou informal.

A firma aparece no contexto da nova economia institucional a partir do trabalho de Coase (1937), The nature of the firm ${ }^{26}$, onde o autor introduz o conceito de custo de transação para explicar por que a firma existe. Coase observa, à página 391, "The main reason why it is profitable to establish a firm would seem to be that there is a cost of using the price mechanism..." ${ }^{\prime 27}$. Dada a existência de custo para utilização do mecanismo de preços, uma alternativa seria um empreendedor coordenar atividades no interior de uma firma. Se o empreendedor conseguir fazê-lo com menores custos, a firma existirá, caso contrário o mecanismo de preços prevalecerá. Surge a idéia de que a firma existe para minimizar os custos de transação.

O custo de transação é um importante componente da teoria da firma na nova economia institucional. Uma transação econômica ocorre quando um bem transita por interfaces tecnologicamente distintas, sendo que elas podem ocorrer tanto no interior das firmas como no mercado. Por exemplo, pode-se fazer uma blusa através de cinco produtores, onde um faz o design, outro faz o corte, outro costura, outro prega o botão e o outro faz o acabamento, ou pode-se colocar essas cinco etapas

\footnotetext{
${ }^{26}$ A natureza da firma (tradução nossa).

${ }^{27}$ A principal razão por que é lucrativo estabelecer uma firma parece ser por que existe um custo para utilização do mecanismo de preços (tradução nossa).
} 
dentro de uma firma. O que vai determinar o limite da firma é a noção de custos de transação.

Williamson (1987, p. 15) expandiu a idéia de custos de transação e passou a chamá-los de custos de transações econômicas. Os custos de transações econômicas incluem os custos de: 1) mal-adaptação, incorridos quando as transações saem de seu curso esperado; 2) barganha, incorridos se esforços bilaterais são feitos para corrigir ex post desalinhamentos; 3 ) organização e ativação, associados a estrutura de Governança e 4) fiança ou de assegurar-se de compromissos seguros (Williamson, 1987, p. 21).

Para expandir a idéia de custos de transação, o autor especifica variáveis que determinam quando o mercado (mecanismo de preços) ou a firma terão menores custos de transação em diversas circunstâncias. Para tanto, Williamson assume as premissas da racionalidade limitada e do oportunismo. A racionalidade limitada refere-se ao fato de que as pessoas possuem memória e processo cognitivo limitados. Não conseguem assimilar todas as informações que estão a sua disposição e não são capazes de perceber todas as consequiências que podem advir das informações que possuem. Oportunismo refere-se a possibilidade das pessoas agirem em seu interesse próprio de forma desonesta.

As variáveis consideradas por Williamson são a frequiência, a incerteza e a especificidade dos ativos. O poder explicativo da teoria provém das três variáveis usadas para caracterizar qualquer transação. As transações podem ser freqüentes ou raras, possuírem alto ou baixo grau de incerteza e envolver ou não ativos com especificidades. As três variáveis, de acordo com a teoria, determinam quando os custos de transação serão menores no mecanismo de preços (mercado) ou na firma, estabelecendo, portanto, oportunidade para surgimento/manutenção da firma ou o uso do mecanismo de preços.

A variável frequiência é de fácil interpretação, pois é evidente que não há razão para trazer para o interior de uma firma uma transação de uso raro. Por exemplo, 
não é interessante para as empresas em geral possuírem seu próprio departamento de consultoria, dado que às utilizam raramente.

A incerteza, no entanto, envolve maior dificuldade pois trata-se de prever os acontecimentos durante o curso de uma transação. O prazo, nesse caso, é um componente importante, pois quanto maior o prazo, maior a dificuldade de fazer previsões. Quando não se trata de curto prazo, surgem os problemas relacionados à racionalidade limitada e ao oportunismo. Tome-se o exemplo de uma empresa jornalística que quer contratar os serviços de uma gráfica. A gráfica precisará fazer investimentos para atender à empresa jornalística e ambas terão interesse em um contrato de longo prazo para garantir suas atividades. Mas, é justamente o longo prazo do contrato que aumenta a incerteza. Que garantia possui a gráfica de que a empresa jornalística não poderá falir durante a vigência do contrato, colocando em risco o investimento efetuado? A incerteza causa problemas, em parte devido à racionalidade limitada, pois esta impede-nos de prever o futuro, e em parte devido à assimetria da informação, que impede o conhecimento da situação de ambas as partes. No exemplo citado, o empresário da gráfica não poderá saber sobre a saúde financeira da empresa jornalística tanto quanto a própria. Da mesma forma o empresário jornalista não poderá saber das reais condições de atendimento de suas necessidade pela empresa gráfica tanto quanto ela mesma. A incerteza também causa problemas devido ao oportunismo. No exemplo, após o empresário da gráfica ter concretizado seu investimento a empresa jornalística poderá, de forma oportunista, propor uma renegociação do contrato firmado. O que precisa ser questionado, para avaliar o benefício de ter-se a atividade integrada de forma vertical na firma ou usar o mecanismo de preços (mercado), é se a incerteza será reduzida optando-se pela atividade de forma integrada. Em caso positivo, deve-se verificar se os custos de transação pelo uso do mecanismo de preços seriam maiores do que os custos associados a integração da atividade.

A última das variáveis consideradas por Williamson é a especificidade dos 
ativos, considerada talvez o elemento mais importante na teoria do autor. Ele argumenta que se a transação envolve ativos que têm valor somente neste contexto, ou o valor do ativo é muito mais valorizado no contexto da transação, ou os custos de transação tendem a ser reduzidos se a opção for pela firma e não pelo mecanismo de preços. No exemplo da gráfica, se as máquinas objeto do investimento não puderem ser utilizadas com outros propósitos ou para fornecer serviços para uma empresa jornalística concorrente, o ativo será muito específico. A variável ativo específico, segundo o autor, só constitui problema no âmbito da racionalidade limitada e do oportunismo. É exatamente isso que torna o investimento do empresário da gráfica muito arriscado e esse risco será apreçado na transação, o que poderá fazer com que o custo de transação pelo uso do mecanismo de preços seja superior ao custo de transação no interior da firma.

Alchian; Demsetz (1972) ofereceram grande contribuição à teoria da firma, à mesma época do trabalho de Williamson (1971), e da célebre frase de Coase sobre seu artigo The nature of de firm: "much cited, litle used"28. As principais idéias de Achian e Demsetz contidas em seu artigo Production, information costs, and economic organization $^{29}$ dizem respeito ao trabalho em grupo, à dificuldade de medir entradas e saídas no trabalho em grupo, à oportunidade de shirk ${ }^{30} \mathrm{e}$ ao monitoramento.

Quanto ao trabalho em grupo, os autores enfatizam que o resultado do trabalho de duas pessoas de forma conjunta, por exemplo, é superior a soma dos trabalhos individuais. Sem citar explicitamente, referem-se ao efeito sinérgico do trabalho em grupo. O adicional de produção resultante do efeito sinérgico deve ser superior aos custos de organizar e gerenciar grupos de trabalho na forma de firma, caso contrário a firma não se justifica.

\footnotetext{
${ }^{28}$ Muito citado, pouco usado (tradução nossa).

${ }^{29}$ Produção, custos da informação e organização econômica (tradução nossa)

${ }^{30}$ Esquivar-se, esforçar-se menos do que poderia (tradução nossa).
} 
$\mathrm{O}$ trabalho em grupo cria uma dificuldade quanto à recompensa que cada elemento deve receber por seu trabalho, pois a mensuração, tanto do esforço de cada um quanto das consequiências (produção) de seus esforços, é muito difícil ou muito onerosa. Imagine-se mensurar os esforços e a produção de um grupo de consultores com o objetivo de remunerá-los justamente e monitorá-los para que dessem o máximo de si para a empresa e, conseqüentemente, para seus proprietários. Por outro lado, não seria muito difícil fazer o mesmo com um grupo de estivadores descarregando um contêiner. Pode-se facilmente observar os esforços de cada um, isto é, o input da atividade produtiva deve ter correlação com a quantidade produzida.

A dificuldade de mensuração de entrada e saída - esforços e produção - faz surgir a oportunidade para os integrantes do grupo esforçarem-se menos do que poderiam (shirk), resultando na redução da vantagem do efeito sinérgico sobre os custos de organização e gerenciamento do grupo. A reação da firma é a redução das recompensas (salários, vantagens ...).

Alchian e Demsetz observam que um método para reduzir o shirking é o monitoramento por pessoas especializadas na atividade. Mas surge a questão: quem irá monitorar o monitor? Uma pressão natural sobre o monitor é o mercado de monitores, alguém da própria empresa ou mesmo de fora, que pode querer ocupar o seu lugar; mas os autores advertem que isso não é muito efetivo. Se os proprietários da empresa concordarem em remunerar o monitor com parte dos lucros, ele então terá um incentivo a mais para trabalhar usando todo o seu potencial. O monitor, de que falam os autores, são os gestores propriamente ditos, pois têm as atribuições de medir performance, pela observação dos esforços de input, distribuir recompensas e instruir sobre o que fazer e como fazer.

Os autores contrapõem o custo de gestão ao custo de transação, dando uma nova interpretação para a razão da existências das firmas preconizada por Coase: 
managing the greater will be the comparative advantage of organizing resources within the firm. ${ }^{31}$

Jensen; Meckling (1976) trouxeram a contribuição dos custos de agência para a nova economia institucional. Esses custos decorrem da separação da propriedade e gestão e constituem esforços para alinhar as ações de proprietários e gestores. São custos relativos a monitoramento (os autores incluem como custo de monitoramento todos os custos incorridos para controlar as ações dos gestores, como políticas de incentivos, orçamentos, regras operacionais...): despesas dos gestores com mecanismos que garantam que suas ações atenderão aos interesses dos proprietários e perdas residuais, que representam as perdas emanadas de decisões dos gestores divergentes das que maximizariam a riqueza dos proprietários,inclusive sob condições ótimas de monitoramento.

Sobre o problema oriundo da separação da propriedade da gestão, Fama (1980, p. 295) discorda de Alchian; Demsetz (1972) e Jensen; Meckiling (1976), que consideram o monitoramento dos gestores diretamente relacionado à propriedade (risk bearing) e postula: "The viability of the large corporation with diffuse security ownership is better explained in terms of a model where the primary disciplining of managers comes through managerial labor market, both within and outside of the firm, [...]"32. Fama acentua o mercado de trabalho de gestores como elemento importante na explicação da existência da firma na forma de sociedade anônima, oferecendo mais uma contribuição à nova econômica institucional, de grande valia para os estudos de Governança Corporativa. O autor pondera também, à p. 292, que se os gestores têm forte incentivo de seu próprio mercado de trabalho, o que os acionistas

${ }^{31}$ Nós podemos, com igual facilidade, subscrever uma teoria da firma baseada no custo de gerenciamento, certamente é verdade que, ceteris paribus, que quanto menor for o custo de gerenciamento tanto maior será a vantagem comparativa de organizar recursos no interior da firma (tradução nossa).

${ }^{32}$ A viabilidade das grandes corporações, com acionistas pulverizados, é melhor explicada em termos de um modelo onde a disciplina dos gestores vem, primeiramente, do mercado de trabalho dos gestores, tanto interno quanto externo, [...](tradução nossa). 
- não interessados em participar ativamente das atividades empresariais e/ou monitorar gestores - estão interessados é em um mercado de capitais que aprece eficientemente as ações da firma.

Coase (1937), Alchian; Demsetz (1972), Williamson (1971, 1973), Jensen; Meckling (1976) e Fama (1980) são considerados trabalhos seminais da teoria da firma no contexto da nova economia institucional e todos fazem referência à relação contratual existente na firma como se pode observar:

- Ronald Coase (1937), prêmio Nobel de economia em 1991 com o trabalho Custos de Transação, Direitos de Propriedade e Organização Industrial, em seu artigo The nature of the firm, "A firm, therefore, consists of the system of relationships which comes into existence when the direction of resources is dependent on an entrepreneur" ${ }^{\prime 3}$;

- Alchian; Demsetz (1972, p. 794),

The essence of the classical firm is identified here as a contractual structure with: (1) joint input production; (2) several input owners; (3) one party who is common to all the contracts of the joint inputs; (4) who has rights to renegotiate any input's contract independently of contracts with other input owners; (5) who holds the residual claim; and (6) who has the right to sell this central contractual residual status. ${ }^{34}$;

${ }^{33}$ Uma firma, então, consiste de um sistema de relacionamento que passa a existir quando a administração de recursos é dependente de um empresário/organizador (tradução nossa).

${ }^{34}$ A essência da firma clássica é identificada aqui como uma estrutura contratual com: (1) recursos de produção conjunta; (2) muitos proprietários dos recursos; (3) uma parte que é comum a todos os contratos de recursos; (4) alguém com direitos para renegociar qualquer contrato de recursos, independentemente dos contratos com outros proprietários de recursos; (5) alguém com direitos sobre os resultados residuais; (6) alguém com direito para vender esse status de contrato residual central (tradução nossa). 
- Williamson (1971, p. 117), "More generally, arguments favorable to integration that turn on 'supply reliability' considerations commonly reduce to the contractual incompleteness issue." ${ }^{35}$;

- Jensen; Meckling (1976, p. 313),

The private corporation or firm is simply one form of legal fiction which serves as a nexus for contracting relationships and which is also characterized by the existence of divisible residual claims [stocks] on the assets and cash flows of the organization which can generally be sold without permission of the other contracting individuals. ${ }^{36} \mathrm{e}$

- Fama (1980, p. 289), "The firm is viewed as a set of contracts among factors of production, with each factor motivated by its self-interest." ${ }^{37}$.

A visão atual da firma como um conjunto de contratos é incorporada em seus objetivos, conforme pode-se constatar no texto de Mas-colell; Whinston; Green (1995, p. 152): "The objectives of the firm assumed in our economic analysis should emerge from the objectives of those individuals who control it. Firms in the type of economies we consider are owned by individuals who, wearing another hat, are also consumers." ${ }^{38}$ Berle; Means (1932) evidenciaram a separação da propriedade e do controle nas empresas, o que implica a necessidade de contratos entre proprietários e controladores. Os autores reconhecem que os objetivos emanam dos controladores e estes possuem contratos com os proprietários não controladores. A parte final do texto

${ }^{35}$ De forma geral, argumentos favoráveis a integração que recaem sobre a consideração da segurança de fornecimento, geralmente, reduzem-se a casos de contratos incompletos (tradução nossa).

${ }^{36}$ A corporação privada ou firma é simplesmente uma forma de ficção legal que serve como uma vinculação para contratar relacionamentos e que também é caracterizada pela existência de exigência sobre resíduos divisíveis (ações) dos ativos e fluxos de caixa da organização que podem geralmente ser vendidos sem a permissão dos outros indivíduos contratantes (tradução nossa).

${ }^{37}$ A firma é vista como um conjunto de contratos entre fatores de produção, em que cada fator é motivado por interesse próprio (tradução nossa).

${ }^{38}$ Os objetivos da firma assumidos em nossa análise econômica teriam de emergir dos objetivos dos indivíduos que a controlam. Firmas, no tipo de economia que nós consideramos, são possuídas por indivíduos que, usando um outro chapéu, são também consumidores (tradução nossa). 
de Mas-colell, Whinston e Green remetem para a idéia de que os controladores também são consumidores e isso implica que possuem uma função utilidade, e maximizá-la não significa, necessariamente, maximizar lucro. Os controladores poderão estar interessados também em status, benefícios indiretos, além de poder beneficiar-se do que Williamson (1987) denominou shirking. Isso não significa dizer que o objetivo da firma não é mais maximização de lucro, pois os autores concluem, à p. 153: "Hence, we conclude that if we maintain the assumption of price-taking behavior, all owners would agree, whatever their utility functions, to instruct the manager of the firm to maximize profit". ${ }^{39}$

Roe (1994, p. VII), citado por Klein (1999), resume a transformação do pensamento econômico sobre a firma:

Economic theory once treated the firm as a collection of machinery, technology, inventory, workers and capital. Dump these inputs into a black box, stir them up and one got outputs and profits. Today, theory sees the firm as more, as a management structure. The firm succeeds if mangers can successfully coordinate the firm's activities; it fails if mangers cannot effectively coordinate and match people and inputs to current technologies and markets. At the very top of the firm are the relationships among the firm's shareholders, its directors and its senior managers. If those relationships are dysfunctional, the firm is more likely to stumble. ${ }^{40}$

${ }^{39}$ Então, nós concluímos que se mativermos a premissa do comportamento dos preços, todos os proprietários deverão concordar, quaisquer que sejam suas funções utilidade, em instruir os gestores da firma para maximizar lucro (tradução nossa).

40 A teoria econômica tratava a firma como uma coleção de máquinas, tecnologia, criatividade, trabalhadores e capital. Coloque isso numa caixa preta, mexa e obtenha produtos e lucro. Hoje, a teoria vê a firma mais como uma estrutura de gerenciamento. A firma tem sucesso se os gestores podem coordenar as atividades da firma eficientemente; ela fracassa se os gestores não podem coordenar e combinar, efetivamente, pessoas e recursos de acordo com a tecnologia e o mercado. No topo da firma existe o relacionamento entre os acionistas, o conselho de administração e os diretores executivos. Se este relacionamento não funcionar adequadamente, a firma provavelmente fracassará. (tradução nossa). 


\subsubsection{Firma e o problema principal-agente}

Observe-se que a firma é um conjunto de conexões de contratos e que parte desses contratos constituem uma relação de principal e agente; por outro lado, a relação principal-agente, objeto da teoria da agência, não aparece exclusivamente na firma. A firma pode possuir contratos com fornecedores, clientes e até mesmo com a sociedade, que não caracterizam uma relação principal-agente. Por outro lado, a relação principal-agente aparece em outras circunstâncias que não a firma como, por exemplo, quando se nomeia uma pessoa como procurador ou elege-se um representante político.

No nexo de contratos que constituem a firma estão inseridos aqueles cujas partes relacionadas são os proprietários e os gestores seniores. No interior da firma, os gestores dos níveis tático e operacional também possuem contratos, informais ou formalizados em instrumentos de avaliação de desempenho, com os gestores do nível estratégico. Os empregados do nível operacional, por seu turno, também possuem contratos com seus gerentes.

Em todos esses contratos constata-se a presença de um principal e de um agente, em que o principal espera do agente um comportamento compatível com seus interesses (interesses do agente). Nesta relação aparecem os problemas relativos a informação assimétrica, cuja conseqüência são contratos incompletos. Williamson (2002, p. 5) citando Simon (1985, p. 303) observa:

All complex contracts are unavoidably incomplete, on which account the parties will be confronted with the need to adapt to unanticipated disturbances that arise by reason of gaps, errors, and omissions in the original contract. Such adaptation needs are especially consequential if, instead of describing self-interest as frailty of motive. ${ }^{41}$

${ }^{41}$ Todos os contratos são, inevitavelmente, incompletos, o que implica que as partes confrontar-se-ão com a necessidade de adaptações a distúrbios não antecipados, ocasionados por lacunas, erros e omissões no contrato original (tradução nossa). 
À Governança Corporativa interessa o estudo das melhores formas de amenizar os problemas de agência, no âmbito da firma, alinhando os interesses dos agentes aos interesses dos acionistas, minimizando os custos de agência derivados de contratos incompletos. Esse não é, contudo, o único foco de atenção dos estudos de Governança Corporativa, pois há também a abordagem dos stakeholders e de outros provedores de capital que extrapola a relação principal-agente.

\subsection{GOVERNANÇA CORPORATIVA}

O termo Governança Corporativa é uma tradução do inglês Corporate Governance, cunhado na esfera da nova economia institucional, para designar influência, controle, direção das ações/condutas daqueles que têm de fato o controle das empresas públicas ${ }^{42}$ (corporações), no caso brasileiro as companhias de capital aberto. A idéia de que o controle efetivo não, necessariamente, está sob a égide dos proprietários, remonta a Adam Smith (1776), contudo, ganhou força efetiva com o célebre trabalho de Berle; Means (1932), The modern corporation \& private property $^{43}$, evidenciando o problema principal-agente, no âmbito da corporação, e dando os primeiros passos na teoria da agência, que constitui hoje a base teórica da maioria dos trabalhos sobre Governança Corporativa (KLEIN, 1999, p.465).

A teoria da agência teve continuidade com Jensen; Meckling (1976), Fama (1980), Fama; Jensen (1983) e Jensen (1986) e estabeleceu o conceito de custos de agência, que constitui um dos eixos de sustentação dos estudos de Governança Corporativa. O foco da atenção está nos mecanismos de Governança Corporativa capazes de minimizar os custos de agência, derivados da impossibilidade do estabelecimento de contratos completos.

\footnotetext{
${ }^{42}$ Pública não significa de controle do poder público, mas sim que está aberta ao público.

${ }^{43}$ A corporação moderna e a propriedade privada (tradução nossa).
} 
As corporações, no entanto, são sucessoras das firmas, constituem firmas públicas (abertas ao capital público) e até o trabalho de Coase (1937) eram tratadas pela economia neoclássica como "caixas-pretas" com objetivo de maximizar lucros pela eficiente alocação de recursos. O questionamento base de Coase, sobre o porquê da existência da firma, trouxe a contribuição do segundo eixo de sustentação dos estudos de Governança Corporativa: o custo de transação para uso do mecanismo de preços (mercado). Williamson (1973, 1981) e Klein; Crawford; Alchian (1978) prosseguiram com o desenvolvimento da idéia de custo de transação. Esta linha de pensamento busca mecanismos de Governança Corporativa capazes de minimizar os custos de transações econômicas, que também envolvem contratos incompletos.

Os estudos de Governança Corporativa possuem, portanto, dois eixos de sustentação: o eixo dos custos de agência, oriundo da vertente de Berle; Means (1932) e o eixo dos custos de transações econômicas, oriundo da vertente de Coase (1937). Williamson (1988, p. 568) considera os custos de agência e os custos de transações econômicas como perspectivas complementares. Ambos são orientados a contratos incompletos, porém com a diferença anotada por Williamson (1988, p. 570):

\begin{abstract}
Although both AT [Agency Theory - agency costs] and TCE [Transaction Costs Economics] are cognizant of both of these contractual design needs [1) realign incentives, 2) craft governance structures that fill gaps, correct error, and adapt more effectively to unanticipated disturbances], AT examines contract predominantly from an ex ante incentive-alignment point of view while TCE is more concerned with crafting ex post governance structures within which the integrity of contract is decided. ${ }^{44}$
\end{abstract}

A observação de Williamson favorece o entendimento das diversas concepções de Governança Corporativa aludidas na literatura sobre o tema. $\mathrm{Na}$

44 Ainda que a teoria da agência e os custos de transações econômicas sejam jurisdicionantes de ambas as necessidades contratuais [1) incentivos de realinhamento, 2) elaborar estruturas de governança que preencham lacunas, corrijam erros e adaptem mais efetivamente à perturbações não antecipadas], a teoria da agência examina contratos de incentivos e realinhamento, predominantemente, sob o ponto de vista ex ante, enquanto os custos de transações econômicas têm mais preocupação com a elaboração ex post de estruturas de governança nas quais a integridade dos contratos é decidida (tradução nossa). 
definição de Mathiesen (2002), por exemplo, "Corporate governance is a field in economics that investigates how to secure/motivate efficient management of corporations by the use of incentive mechanisms, such as contracts, organizational designs and legislation" ${ }^{45}$, percebe-se a ótica da teoria da agência em [...] how to secure/motivate efficient management of corporations by the use of incentive mechanisms $[\ldots]^{46}$. A preocupação com o conflito principal-agente é explícita e o mecanismo de minimização de custo de agência é dado (incentivo). É a abordagem $e x$ ante do contrato. Já na definição de Denis; Mcconnell (2002, p.1),

We define corporate governance as the set of mechanisms - both institutional and market-based - that induce the self-interested controllers of a company (those that make decisions regarding how the company will be operated) to make decisions that maximize the value of the company to its owners (the suppliers of capital) ${ }^{47}$,

A expressão "[...] both institutional and market-based [... $]^{48 " ~ e x t r a p o l a ~ o ~}$ âmbito da empresa na medida em que faz referência a mecanismos institucionais, que podem ser privados ou públicos (códigos de boas práticas de Governança Corporativa e leis de companhias abertas por exemplo), e a mecanismos de mercado. Os mecanismos de Governança implícitos são o arcabouço legal (proteção de acionistas, por exemplo) e o mercado de trabalho de gestores, o que os faz terem preocupação com sua reputação. É a abordagem ex post dos contratos.

Cada uma das abordagens dos contratos ex ante e ex post podem implicar

45 Governança Corporativa é um campo da economia que investiga como assegurar/motivar os gestores das corporações, através de mecanismos de incentivo como contratos, estruturas organizacionais e legislação (tradução nossa). [...] (tradução nossa).

${ }^{46}[\ldots]$ como motivar a gestão eficiente das empresas pelo uso de mecanismos de incentivo

${ }^{47}$ Nós definimos Governança Corporativa como um conjunto de mecanismos - baseados em ambos instituições e mercados - que induzem controladores oportunistas de uma companhia (aqueles que tomam decisões sobre como a companhia será operada) a tomarem decisões que maximizem o valor da companhia para seus proprietários (os provedores de capital) (tradução nossa).

\footnotetext{
${ }^{48}[\ldots]$ ambos institucional e baseados em mercado [...] (tradução nossa).
} 
diversos tipos de mecanismos de Governança Corporativa. Mecanismos de incentivos aos gestores, como remuneração variável baseada em resultados e opções de compra sobre ações da empresa, e de monitoramento, como auditoria independente, conselho de administração - com a observância de composição com membros externos, presidência exercida por pessoa que não o presidente da empresa -, conselho fiscal, auditoria interna, comitê de auditoria interna, covenants ${ }^{49}$ atrelados a recursos tomadas de terceiros, processo de gestão com segregação de funções e estrutura de propriedade, constituem a abordagem ex ante dos contratos.

Por outro lado; leis, códigos de ética, códigos de boas práticas de Governança Corporativa, câmaras de arbitragem, mercado de trabalho dos gestores, mercado de trabalho dos membros dos conselhos de administração e o mercado de controle acionário (takeovers) são mecanismos de Governança Corporativa relacionados a abordagem ex post dos contratos.

Todos os mecanismos de Governança Corporativa possuem um objetivo comum, qual seja: reduzir custos de agência e custos de transações econômicas que, em última análise, contribuem para maximizar a riqueza dos acionistas, garantir o retorno dos capitais de terceiros e oferecer aos stakeholders o benefício do desenvolvimento econômico do país onde a empresa está inserida.

Zingales (1997) argumenta que só faz sentido discutir o assunto Governança Corporativa sob a hipótese de contratos incompletos e intrinsecamente relacionados à firma. Tendo presente a idéia de firma como uma conexão de contratos formais e informais entre proprietários, gestores, financiadores, funcionários, fornecedores, consumidores..., pode-se observar quatro modelos de Governança Corporativa (HAWLEY; WILLIAMS, 1996): modelo financeiro, modelo stewardship, modelo stakeholder e modelo político.

49 Compromisso formal de manutenção de determinados parâmetros mínimos e/ou máximos de indicadores econômico-financeiros da empresa (tradução nossa). 
O modelo financeiro pode ser simples, cujo problema central da Governança Corporativa são contratos (implícitos ou explícitos) que alinhem as ações dos gestores ao interesses dos acionistas ou, mais abrangente, incluindo os interesses de todos os financiadores da firma (aqueles que possuem direitos de crédito). Observe-se que no modelo mais abrangente o problema da Governança Corporativa extrapola a teoria da agência (conflito principal-agente), evidenciando a necessidade de considerar-se, além dos custos de agência, os custos de transações econômicas. No modelo stewardship, os gestores são bons "mordomos" da empresa e trabalham com zelo para obter altos níveis de lucro e retorno para os acionistas (DONALDSON; DAVIS, 1994). Sob a ótica do modelo stakeholder, a Governança Corporativa transcende a preocupação com os acionistas e financiadores e alcança todas as pessoas que possuem algum interesse na empresa. $\mathrm{O}$ objetivo da empresa fica mais abrangente e baseia-se não só na maximização da riqueza dos acionista e na devolução dos capitais, devidamente remunerados a seus proprietários, mas na maximização da riqueza total que a empresa pode proporcionar. É um desafio à Contabilidade a criação de medidas de performance da riqueza total gerada para a sociedade, que tem sido respondido com o Balanço Social. Por fim, o modelo político reconhece que a distribuição de poder, privilégios e lucros entre proprietários, gestores e stakeholders é determinada pelas condições de favorecimento de cada um dos vários eleitores. O modelo considera a habilidade política e os instrumentos utilizados pelos interessados na empresa para obter vantagens.

O tema Governança Corporativa é emergente e tem despertado a atenção de acadêmicos, legisladores, acionistas, gestores de empresas e de bolsas de valores de todo o mundo. Outras abordagens sobre o tema podem ser encontradas em Siffert Filho (1998), Ali; Hwang (2000), Carvalho (2002, 2003), La Porta; Lopes-de-Silanes; Shleifer; Vishny (1997, 1998, 2000), Hawley; Williams (1996), Mcconomy; Bujaki (2000), Turnbull (2000), Harm (2003), Gompers; Ishi; Metrick (2001), Ribeiro Neto; Fama (2001), Tiroli (2001), Almeida; Almeida; Ness (2002), Denis; Mcconnell 
(2002), Leal; Ferreira (2002) e Srour (2002).

\subsection{GOVERNANÇA CORPORATIVA E CONTABILIDADE}

A importância da Contabilidade no contexto da Governança Corporativa, tendo a firma como um nexo de contratos, já era reconhecida por Watts; Zimmerman (1986, p. 196) quando os estudos sobre Governança estavam em seu estado embrionário ${ }^{50}$ :

Contracts will not reduce the costs of conflicts (agency costs) unless the parties can determine whether the contract has been breached. Hence, in the "nexus of contracts" view of the firm, there is a demand for monitoring contracts. The "property rights" or contracting literature suggests the hypothesis that accounting plays an important role both in contract terms and in monitoring those terms. ${ }^{51}$

Como se pode observar, o elo entre Contabilidade e Governança Corporativa é muito claro. Uma das vertentes dos estudos de Governança acentua a necessidade de redução dos custos de agência, quer pelo monitoramento, quer através de incentivos aos gestores; outra enfatiza também os provedores de capitais para a firma de forma a incluir debtholders e bancos, além dos acionistas. Essas relações implicam contratos baseados em informações contábeis.

No que se refere aos mecanismos de monitoramento, a Contabilidade está presente nas auditorias independentes, que avaliam e garantem a veracidade das informações contábeis, nas empresas de rating, que também se apóiam nas

50 Até vinte anos atrás o termo Corporate Governance não existia na língua inglesa (Zinagales, 1997) (tradução nossa).

${ }^{51}$ Contratos não reduzirão custos de conflitos (custos de agência) a menos que as partes possam determinar quando os contratos são quebrados. Então, na visão da firma como "nexo de contratos" existe uma demanda por monitoramento de contratos. O "direito de propriedade" ou literatura de contratos, sugere a hipótese que a contabilidade exerce um papel importante tanto nos termos da contratação quanto no monitoramento desses termos (tradução nossa). 
informações contábeis para efetuar suas classificações de riscos e nas atividades dos conselhos fiscais e conselhos de administração. Para os investidores com menores participações acionárias nas empresas e que, portanto, não compartilham a gestão ou possuem assento no conselho de administração, a Contabilidade também contribuiu para reduzir a assimetria de informações na medida em que as demonstrações financeiras das empresas são objeto de análise pelos analistas de mercado e estas análises são acessíveis a custo zero ou a baixo custo. Outro exemplo do uso da Contabilidade em mecanismos de monitoramento aparecem nos covenants quando da emissão de títulos de dívida ou tomada de recursos no sistema bancário. Nessas circunstâncias, os gestores comprometem-se com níveis mínimos ou máximos de determinados indicadores baseados em informações contábeis.

No que concerne aos mecanismos de incentivo da Governança Corporativa, embora menos freqüente do que no monitoramento, a remuneração variável de gestores baseada em medidas contábeis também aparece.

Para não se ficar restrito a Contabilidade Financeira, vale sublinhar a contribuição da Contabilidade Gerencial à Governança Corporativa. Fama (1983) aponta como importante mecanismo de controle dos gestores pelos acionistas a estruturação do processo decisório da empresa (observação mais atenta do artigo de Fama permite inferir que ele refere-se ao processo de gestão propriamente dito), de forma a segregar as decisões de gestão e de controle (o autor considera decisões de gestão as de iniciar propostas do uso de recursos e de implementar; e decisões de controle as de ratificar iniciativas e monitorar). Como exemplos da contribuição da Contabilidade Gerencial à Governança, relacionados ao processo de gestão da empresa (observe-se que o problema principal-agente aparece em toda a escala hierárquica da organização), podemos citar simulações de resultados para subsidiar o planejamento estratégico e operacional, o orçamento gerencial, o orçamento de capital, as informações de custo, o planejamento tributário e o resultado de unidades internas da empresa, sendo este último utilizado nos programas de remuneração variável dos 
funcionários. É, portanto, a Contabilidade Gerencial a fonte de informações para o monitoramento e incentivo interno da empresa.

Sloan (2001, p. 339) reconhece o caráter interdisciplinar do tema Governança Corporativa, permeando a economia, finanças, direito e administração, e afirma que a Contabilidade tem um papel potencialmente importante na pesquisa sobre Governança, pois provê as informações requeridas para a maioria dos mecanismos de Governança operarem eficientemente. O autor observa, também, à p. 341, que, a despeito da importância da Contabilidade Financeira para a Governança Corporativa, a pesquisa corrente é modesta e os não contadores têm feito os avanços mais significativos. Reconhece, como resultado, que existe uma grande oportunidade para pesquisas futuras baseadas na Contabilidade.

Se trouxermos as queixas de Sloan para o Brasil, a situação é ainda mais grave, pois a área de estudos Contábeis no Brasil, mesmo onde há um centro de excelência com graduação até o nível de doutorado (Universidade de São Paulo), deixa a desejar em estudos empíricos em geral. O que dizer, então, sobre a relação Contabilidade e Governança Corporativa, sendo este último tema emergente no mundo. Veja-se as conclusões de Martins (2002, p. 87) em seu artigo Divulgação de trabalho: considerações sobre os doze anos do Caderno de Estudos:

\footnotetext{
A produção científica na área contábil ainda é pouco original, periférica e de qualidade discutível. O expressivo aumento da produção de dissertações e teses, verificada nos últimos anos, não foi acompanhado de aumento da qualidade, nem tampouco resultou em equivalente produção de artigos orientados por pesquisas empíricas.
}

Reconheça-se, porém, como um dos exemplos de exceção, que não só reúne a necessária característica empírica, sempre desejável nos trabalhos científicos, como é pertinente ao assunto Governança Corporativa, o trabalho de Lopes (2002), The value relevance of brazilian accounting numbers: an empirical investigation, que pesquisa a relevância da informação contábil, lucro e valor patrimonial das ações, no papel de reduzir o problema da assimetria informacional entre firma e acionistas, concluindo 
pela relevância da informação do valor patrimonial das ações e pela irrelevância da informação de lucro.

Bushman; Smith (2001, p. 96) apresentam uma extensa pesquisa sobre o uso da Contabilidade Financeira nos mecanismos de Governança Corporativa de incentivo aos gestores e sugerem aos pesquisadores contábeis a exploração de quatro outros temas:

The first theme is whether the availability of financial accounting information affects economic performance, and by how much. ... The second theme is to investigate the specific channels through which financial accounting information affects economic performance, with an emphasis on isolating the effects of the governance role of financial accounting information. The third theme is how the effects of financial accounting information on economic performance vary with other factors, such as the auditing regime, legal protection of investors' rights and other corporate control mechanisms, or the relative importance of securities markets versus bank financing. [...]The fourth theme is the economic effects of disclosures of specific types, the frequency of interim reporting, and the accounting principles used to measure the disclosed items. ${ }^{52}$

O presente trabalho permeia as sugestões de Bushman e Smith por utilizar medidas de performance econômica baseadas na Contabilidade como retorno sobre o ativo, retorno sobre o patrimônio líquido, medidas híbridas (baseadas em mercado e na Contabilidade) como Tobin's $\mathrm{Q}^{53}$ e a razão entre preço de mercado e preço patrimonial das ações. A Contabilidade também está presente nos mecanismos testados como o

${ }^{52} \mathrm{O}$ primeiro tema é será que existência de informações contábeis financeiras afetam a performance econômica, e em quanto. [...] O segundo tema é investigar os canais específicos através dos quais as informações contábeis financeiras afetam a performance econômica, com uma ênfase no isolamento dos efeitos do papel da governança sobre as informações contábeis financeiras. O terceiro tema é como os efeitos das informações contábeis financeiras variam com outros fatores, como auditoria, proteção legal dos direitos dos investidores e outros mecanismos de controle corporativo, ou a relativa importância do mercado acionário versus mercado financeiro bancário. ... O quarto tema são os efeitos econômicos de tipos específicos de disclosures, a freqüência das publicações e os princípios contábeis utilizados para medir os itens de disclosures (tradução nossa).

${ }^{53}$ Quociente entre o valor da emp;resa e o valor total de seus ativos. 
endividamento, pay $\mathrm{ou}^{54} t$, dividend yield ${ }^{55}$ e auditoria independente.

\subsection{EVIDÊNCIAS EMPÍRICAS DE MECANISMOS DE GOVERNANÇA CORPORATIVA E HIPÓTESES SUBJACENTES}

A eficácia da Governança Corporativa consiste em utilizar mecanismos capazes de alinhar as ações dos gestores aos interesses dos acionistas ou, em sentido mais amplo, aos interesses dos provedores de capital ou até mesmo de todos os stakeholders, aos menores custos. O alinhamento de interesses faz-se necessário porque os contratos são incompletos por natureza e conflitos são inevitáveis. Se consideramos a função objetivo da empresa como sendo maximizar o valor de mercado dessa, ou da riqueza de seus proprietários, percebe-se que a separação de propriedade e gestão, inerente às organizações modernas, à luz da teoria da agência, representa um distúrbio que implica redução do valor da empresa pelo montante dos custos de agência. Dessa forma, a função objetivo só seria maximizada mediante a minimização dos custos de agência. E é exatamente isso que as boas práticas de Governança Corporativas preconizam.

Os mecanismos cujos propósitos são atenuar os problemas relacionados ao segundo conflito aludido neste estudo, referem-se a leis e regulamentos (lei das sociedades anônimas no caso brasileiro, princípios de contabilidade geralmente aceitos, eficiência do sistema judicial e dos órgãos reguladores e normas das bolsas de valores) que protegem os acionistas minoritários e stakeholders (veja-se, por exemplo Shleifer; Vishny (1997) e La Porta et al., (2000)

A competição de mercado pelo controle de empresas, por si só, deveria

\footnotetext{
${ }^{54}$ Dividendos propostos na Demonstração das Origens e Aplicações de Recursos (DOAR) dividos
} pelo lucro líquido.

\footnotetext{
${ }^{55}$ Soma dos dividendos por ação pagos no período dividida pelo lucro líquido
} 
funcionar como mecanismo de Governança Corporativa (FAMA, 1980; FAMA; JENSEN, 1985 e STULZ, 1988). Bohren; Odegaard (2001, p. 5) observam que quando produtos, trabalho e takeovers são completamente competitivos, os gestores tendem a maximizar o valor da empresa e a competição seria o único mecanismo de Governança Corporativa necessário. Mesmo na ausência de competição, o problema da separação propriedade-gestão poderia ser resolvido mediante contratos que especificassem completamente, e em qualquer situação, os direitos e deveres de proprietários e gestores. Como esses contratos não podem ser construídos/firmados na prática sem custos excessivos (HART, 1995 e VIVES, 2000), mecanismos adicionais de Governança são necessários.

Os mecanismos de Governança Corporativa podem ser resumidos em mecanismos de incentivo e monitoramento (abordagem ex ante dos conflitos) e mecanismos contidos no ambiente institucional (abordagem ex post dos conflitos).

Neste trabalho, consideram-se seis mecanismos de incentivo e monitoramento, denominados como:

- concentração de propriedade;

- características do conselho de administração;

- capital votante;

- política de remuneração da diretoria executiva;

- política financeira;

- controle interno.

Outros mecanismos, que são ditos de monitoramento, são a competição dos produtos no mercado, que força a eficiência e eficácia dos gestores; o mercado de trabalho de gestores, externo e interno à empresa, que os faz serem competitivos (FAMA, 1980); e a competição de mercado pelo controle das empresas (MANNE, 1965), os denominados takeovers. 
A escolha dos mecanismos incluídos no estudo considerou a necessidade de se fazer estudos sobre Governança Corporativa e performance mais abrangentes. Como mencionado anteriormente, em geral, os pesquisadores testam um ou dois mecanismos de Governança e medidas de performance econômica baseadas em mercado e na contabilidade. Contudo, o número de mecanismos incluídos no estudo foi condicionado à existência de dados.

Nos subitens seguintes passa-se a examinar o suporte teórico e evidências empíricas de cada um dos mecanismos elegidos para o estudo, ao tempo em que formulam-se as hipóteses pertinentes a cada um.

\subsubsection{Concentração de propriedade}

La Porta et. al (1998) estudaram a concentração de propriedade em 27 países e concluíram que, exceto em países com muito boa proteção a acionistas minoritários, poucas empresas tem a propriedade pulverizada; contrariamente a idéia derivada do trabalho de Berle; Means (1932) sobre as grandes empresas. Os autores constataram que o controle das empresas é tipicamente de famílias e do Estado.

Holderness; Sheehan (1988) encontraram centenas de empresas de capital aberto (com ações em bolsa) com mais de cinqüenta e um por cento de concentração de propriedade nos Estados Unidos. Os três maiores acionistas, mesmo nos Estados Unidos, chegam a ter quase 20\%, em média, do controle das empresas. A concentração também é alta em outros países como Itália, Espanha, Alemanha e Japão. No Brasil há também concentração de propriedade com predominância de grupos familiares no controle acionário das empresas.

As pesquisas sobre a relação entre concentração de propriedade e performance das empresas produziram resultados não consistentes até agora, veja-se os seguintes exemplos: 
- Hobbs (2000) cita o trabalho de Thomsen; Pedersen (2000) que, usando uma amostra de 435 das maiores empresas Européias, encontraram efeito positivo da concentração de propriedade sobre a medida de performance market to book value e sobre o retorno sobre ativos, mas em altos níveis de concentração;

- Carvalhal (2002, p. 45), testou a hipótese "quanto maior a concentração de direito de voto, por menos o mercado vai avaliar essas empresas", sob a argumentação de que a concentração de propriedade com direito a voto potencializa o poder de expropriação dos acionistas minoritários, utilizando uma amostra de 225 empresas privadas brasileiras, com dados 1998, e com as medidas de performance Tobin's Q e a razão preço de mercado e valor patrimonial das ações. Os testes efetuados, utilizando análise de variância, rejeitaram a hipótese;

- Uma pesquisa de Gugler (2001), em trabalhos sobre concentração de propriedade entre 1932 e 1998, encontrou 12 casos com relação positiva entre concentração e performance, 13 neutros e 2 com relação negativa.

No entanto, quando a propriedade é separada do controle, a teoria da agência argumenta que, se o monitoramento dos gestores é fraco, pode haver destruição de valor da empresa (JENSEN; MECKLING, 1976; DEMSETZ; LEHN, 1985). Para que um proprietário tenha incentivos de ordem econômica para incorrer em custos de monitoramento e mesmo ter poder para monitorar efetivamente, ele precisa possuir uma quantidade expressiva de ações. Se o monitoramento dos gestores, por parte do(s) proprietário(s) melhora a qualidade das decisões dos gestores, e se isso não produz nenhum outro efeito, performance econômica e concentração de propriedade devem ser positivamente correlacionadas (SHLEIFER; VISHNY, 1986; BOHREN; ODEGAARD, 2001).

A concentração de propriedade, porém, deve ter muitos outros efeitos, além 
do incentivo para monitorar e o poder para tal. Ser um proprietário com poder para monitorar implica custos: Primeiro, porque precisa investir parte significativa de seus recursos em uma empresa, abdicando do benefício da diversificação como instrumento de gestão de risco (DEMSETZ; LEHN, 1985). Segundo, o monitoramento reduz o valor de mercado da empresa. De acordo com o modelo teórico de Burkart (1997), a interferência dos proprietários na gestão retrai as ações dos gestores na busca de projetos mais rentáveis para a empresa. Dessa forma, os proprietários enfrentam um trade-off entre os ganhos do monitoramento - minimização do conflito propriedadecontrole - e as perdas decorrentes de menores iniciativas dos gestores. Por fim, a premissa implícita no argumento do benefício do monitoramento é a de que os proprietários são competentes, isto é, eles sabem melhor do que os gestores como conduzir uma empresa com objetivo de maximizar seu valor. Se essa premissa for falsa, deve-se esperar o efeito inverso. Ou seja, quanto maior a concentração de propriedade, menor a performance econômica (BOHREN; ODEGAARD, 2001).

Nossa hipótese para o mercado brasileiro considera que os benefícios do monitoramento exercido por acionistas com poder de controle sobre a empresa superam as perdas decorrentes da retração por parte dos gestores na busca de projetos mais rentáveis. Assim:

H1: A concentração de propriedade das empresas está positivamente relacionada com a performance econômica.

\subsubsection{Características do conselho de administração}

No Brasil, dentre as competências do conselho de administração, conforme Art. 142 da Lei n. 6.404, de 15.12.76 (Carvalhosa; Eizirik, 2002, p. 288), consta a fixação da orientação geral dos negócios da companhia, a eleição e destituição de diretores, a fiscalização da gestão dos diretores e a escolha e destituição dos auditores 
independentes. Os Princípios de Governança Corporativa da Bolsa de Valores de Nova Iorque (NYSE), p. A-34, aludem que "The business of a corporation is managed under the direction of the corporation's board. [...] Directors monitor management on behalf of the corporation's stockholders." ${ }^{56}$. A Comissão de Valores Mobiliários (CVM) do Brasil, no item II.1 de Recomendações da CVM sobre Governança Corporativa, inclui, como função do conselho de administração, a orientação à diretoria a fim de maximizar o retorno do investimento.

O conselho de administração é considerado o principal mecanismo de monitoramento disponível aos proprietários da empresa. A ele compete assegurar que o diretor presidente (CEO) e demais integrantes da diretoria executiva conduzam suas responsabilidades de acordo com o interesse dos proprietários (FAMA, 1980; JENSEN; MECKLING, 1976).

Embora as conclusões das pesquisas empíricas não tenham produzido conclusões consistentes a respeito da influência da composição dos conselhos de administração sobre a performance econômica das empresas, como veremos adiante, certas características são recomendadas como boas práticas de Governança Corporativa. No Brasil, por exemplo, as Recomendações da CVM (Comissão de Valores Mobiliários) sobre Governança Corporativa, de junho de 2002, preconizam que o conselho tenha de 5 a 9 membros tecnicamente qualificados, com pelo menos dois membros com experiência em finanças e responsabilidade de acompanhar mais detalhadamente as práticas contábeis adotadas. Recomendam, ainda, que o conselho tenha o maior número possível de membros independentes da administração da companhia e que o presidente do conselho não seja a mesma pessoa que ocupa o cargo de diretor presidente. O código de melhores práticas de Governança do Instituto Brasileiro de Governança Corporativa também recomenda de 5 a 9 membros no

${ }^{56} \mathrm{O}$ negócio de uma empresa é gerido sob a direção do Conselho de administração. [...]Membros do Conselho monitoram os gestores em nome dos acionistas da empresa (tradução nossa). 
conselho de administração, em que as empresas devem evitar que diretores sejam conselheiros e que haja separação da presidência do conselho de administração da presidência da diretoria executiva. O regulamento do Novo Mercado da Bolsa de Valores de São Paulo, por seu turno, preconiza um mínimo de 5 membros para o conselho de administração. Os Princípios de Governança Corporativa da Bolsa de Valores de Nova Iorque (NYSE), p. A-38, consideram que a experiência de muitos membros de conselhos de administração sugere que conselhos menores são freqüentemente mais coesos e trabalham mais efetivamente do que os maiores.

A seguir, examinam-se alguns estudos empíricos sobre a estrutura dos conselhos de administração:

- Bhagat; Black (1999) pesquisaram 928 grandes empresas americanas com dados de 1985 a 1995, usando medidas de performance de natureza contábil, e de mercado e não encontraram evidências convincentes de que a performance econômica das empresas está positivamente relacionada à proporção de membros do conselho de administração externos à empresa;

- Silveira (2002), utilizando dados de cerca de 200 empresas do mercado brasileiro relativos aos anos de 1998 a 2000, concluiu que quando a presidência da empresa e a presidência do conselho de administração é ocupada por pessoas distintas, as empresas apresentam melhor performance econômica. Quanto à relação entre tamanho do conselho de administração e medidas de performance, os resultados de Silveira mostraram-se inconsistentes. O mesmo ocorreu à variável que expressava a independência do conselho;

- Baliga; Moyer; Rao (1996) pesquisaram a relação entre o exercício conjunto das presidências do conselho de administração e da diretoria executiva pela mesma pessoa ( $C E O$ duality) e a performance econômica, utilizando como amostra as 500 maiores empresas listadas na revista 
Fortune de 1990 e medidas de performance contábeis e de mercado. Suas conclusões contradizem as recomendações de separação das duas presidências como mecanismos de Governança para melhorar performance. Observam, citando Pfeffer (1981), que talvez a separação sirva mais como um sinal, para o mercado, de boa prática do que efetividade na melhoria de performance;

- Dalton; Daily (2000) pesquisaram os resultados de 131 estudos em 20.620 empresas utilizando a técnica de meta análise ${ }^{57}$. A pesquisa mostrou que conselhos de administração maiores estão associados a melhores performances das empresas, mesmo quando considerado o segmento a que a empresa pertence e independente de como a performance foi medida. Observe-se que esta conclusão contradiz o conteúdo dos Princípios de Governança Corporativa da Bolsa de Nova Iorque, mencionados anteriormente.

Outros estudos empíricos sobre a estrutura do conselho de administração podem ser examinados nos artigos de John; Senbet (1998), Eisenberg; Sundgren; Wells (1998), Dalton (1987), Daily (1997), Barnhart (1998), Hermalin; Weisbach (1991), Lawrence; Stapledon (1999), Barnhart; Rosenstein (1998) e Harm (2000).

A hipótese de estudo para a estrutura do conselho de administração das empresas brasileiras será expressa da seguinte forma:

H2: A performance econômica das empresas está negativamente relacionada com o número de integrantes do conselho de administração, com o exercício duplo da presidência da diretoria executiva e do conselho de administração pela mesma pessoa e com o número de integrantes do conselho de administração que são internos à empresa.

${ }^{57}$ Meta análise é uma técnica estatística que, enquanto corrige por vários instrumentos estatísticos, permite a agregação de resultados dos estudos para obter uma estimativa da verdadeira relação entre duas variáveis na população (Dalton e Daily, 1998) (tradução nossa). 


\subsubsection{Capital votante}

O capital votante, representado pelas ações da empresa com direito a voto, é de fato o que viabiliza a participação do acionista no monitoramento das ações dos gestores. A Lei 6.404, de 15.12.76, exigia que no mínimo um terço do capital das companhias abertas fosse constituído de ações com direito a voto. A nova Lei das S.A., Lei 10.303, de 31.10.2001, alterou esse dispositivo elevando a proporção mínima para cinqüenta por cento. No entanto, as empresas que já possuíam mais de cinqüenta por cento de ações sem direito a voto poderão permanecer desta forma indefinidamente (Carvalhosa; Eizirik, 2002, p. 69).

A existência de poucas ações com direito a voto no mercado pode implicar baixa liquidez do papel, pouca procura por parte dos investidores e a exigência de alto prêmio de risco devido a probabilidade maior de serem expropriados.

O item 1.01, do Código das Melhores Práticas de Governança Corporativa do Instituto Brasileiro de Governança Corporativa - IBGC, prescreve que todas as ações da empresa devem dar direito a voto - uma ação, um voto.

Nas Recomendações da CVM sobre Governança Corporativa, também encontra-se explícita a preocupação com as ações que dão direito a voto como boa prática. Textualmente, no item III.7: “O objetivo é estimular que as companhias tenham cada vez mais o capital composto por ações com direito a voto."

A Bolsa de Valores de São Paulo (BOVESPA), por seu turno, faz constar do regulamento para adesão das empresas ao Novo Mercado, no item 3.1, inciso VII: “tenha seu capital social dividido exclusivamente em ações ordinárias [...]”.

Estudos empíricos testando a relação entre a proporção de ações que dão direito a voto e a performance da empresa são escassos. Bohren; Odegaard (2001), que efetuaram trabalho com essa variável como mecanismo de Governança Corporativa relatam, à p. 13: "To our knowledge, no paper has yet analyzed the empirical 
relationship between security design and economic performance in a corporate governance setting. ${ }^{" 58}$. Os autores encontraram relação negativa entre o capital votante (proporção de ações com direito a voto) e a performance econômica das empresas testadas. Isto é, quanto maior a proporção de capital votante, menor é a performance econômica.

Contudo, se as boas práticas de Governança Corporativa recomendadas de fato produzem efeito, a seguinte hipótese pode ser formulada:

H3: A performance econômica das empresas está positivamente relacionada com o percentual do capital lastreado em ações ordinárias nominativas.

\subsubsection{Política de remuneração da diretoria executiva}

Os mecanismos de Governança Corporativa utilizados para dirimir os problemas de contratos incompletos objetivam monitorar ou incentivar as ações dos gestores. Para incentivar os gestores, as empresas utilizam o pagamento de bônus ou planos de performance, geralmente baseados em medidas de performance de base contábil (WATTS; ZIMMERMAN, 1986, p.202). Também podem ser utilizados planos com opções sobre ações com diversas variações quanto à data para exercício (MURPHY, 1998, p.5).

Barkema; Gomez-Mejia, (1998, p.135) reporta que a compensação de executivos (incentivos) tem sido objeto de estudo por mais de 70 anos e acumula mais de 300 estudos. O tópico mais pesquisado é a remuneração do diretor presidente (CEO) e tais estudos consideram que uma relação positiva entre a compensação do diretor presidente e a performance da empresa é consistente com a teoria da agência. No entanto, pesquisadores (ex. JENSEN; MURPHY, 1990; KERR; BETTIS, 1987)

${ }^{58}$ De nosso conhecimento, nenhum artigo ainda analisou empiricamente a relação entre a composição do capital e a performance econômica sob a ótica de governança corporativa (tradução nossa). 
usando diferentes dados, diferentes medidas e técnicas estatísticas diversas têm encontrado fraca ou até nenhuma relação estatisticamente significante entre o pagamento de incentivos/compensações e a performance das empresas.

Um amplo estudo de Jensen; Murphy (1990) deixou-os desapontados com a baixa sensibilidade da performance das empresas em relação aos planos de incentivos dos diretores presidentes.

Outros estudos empíricos sobre incentivos como mecanismo de Governança Corporativa incluem Beatty; Zajac (1994), Murphy (1999), Hermalin; Weisbach (1991) e Gibbons (1998).

Murphy, 1998, p. 53, observa que as práticas de incentivos variam com o tamanho da empresa, indústria a que pertence e país onde estão estabelecidas. Os salários nos Estados Unidos, por exemplo, são maiores que em outros países em média e os níveis de salários são mais altos e menos sensíveis a performance em grandes empresas.

A hipótese do estudo para esse mecanismo de Governança Corporativa seguirá a dos demais estudos empíricos sobre o assunto, baseada na teoria da agência. Dessa forma:

H4: A performance econômica das empresas está positivamente relacionada com a remuneração total da diretoria executiva e com a existência de programa de participação nos lucros.

\subsubsection{Política financeira}

A política financeira constitui: as decisões de investimento da empresa, as decisões de financiamento e as decisões relativas a dividendos. Este estudo trabalha com a relação dívida e ativo total, que está no contexto das decisões de financiamento, e pay out e dividend yield no contexto das decisões sobre dividendos. 
Bohren; Odegaard (2001) mencionam que; exceto pelo estudo de Agrawal; Knoeber (1996), que modela a relação dívida sobre valor de mercado (ações) como um dos sete mecanismos de Governança; as pesquisas existentes somente incluem política financeira como variável de controle.

Contudo, a política financeira, no que diz respeito a relação dívida e ativos totais, constitui um mecanismo de Governança na medida em que as dívidas contraídas pelo gestores restringem suas ações através de mecanismos de monitoramento de condições que advém desses contratos. São os denominados covenants. Watts; Zimmerman (1986, p. 210) abordam algumas dessas restrições baseadas em números contábeis. São, por exemplo, restrições quanto a pagamento de dividendos, manutenção de certo nível mínimo de capital de giro, restrições quanto a fusões e aquisições, restrições quanto a emissão de novas dívidas e restrições de investimentos em outras empresas.

No que concerne à política de dividendos, John; Williams (1985) observam que, em condições de informações assimétricas, os dividendos podem agir como sinais críveis para o mercado de empresa com alta rentabilidade. Empresas com informações positivas sobre seu desempenho podem pagar dividendos para seus acionistas, o que seria difícil para uma empresa que não estivesse em boas condições. O mercado, então, interpreta essa atitude de forma positiva e paga maiores preços pelas ações.

Empresas que pagam maiores dividendos, possuem mais facilidade de captar recursos mais baratos, o que melhora sua performance e sua atratividade no mercado.

A hipótese do estudo para o mecanismo de Governança política financeira é expressa da seguinte forma:

H5: A performance econômica das empresas está positivamente relacionada com o uso de capital de terceiros e com a política de dividendos praticada. 


\subsubsection{Controle interno}

As boas práticas de Governança recomendam a constituição de um comitê de auditoria (Recomendações da CVM sobre Governança Corporativa, item IV.3 e Princípios de Governança Corporativa da Bolsa de Valores de Nova Iorque (NYSE), p. A-41, Toronto Stock Exchange - Bolsa de Valores de Toronto - Mcconomy; Bujaki (2000, p. 10)). Esse comitê, cujos representantes devem incluir membros externos à empresa com experiência em finanças e com condições de entender o negócio da empresa e seus riscos, é a interface entre os mecanismos de controles internos da empresa, mormente da auditoria interna e o conselho de administração, por um lado; por outro, deve ser a interface entre os auditores independentes e o conselho de administração. Isso objetiva subsidiar o conselho de administração na incumbência de atentar para controles internos capazes de viabilizar a gestão de riscos da empresa.

O comitê de auditoria também subsidia o conselho na seleção e avaliação do trabalho dos auditores independentes, de forma a garantir que estes sejam competentes e independentes. O item IV.4 da Recomendações da CVM sobre Governança Corporativa expressa que: "As práticas de boa Governança recomendam a completa independência dos auditores como requisito da qualidade de sua atuação."

É a competência e a independência dos auditores independentes que os torna um mecanismo de Governança Corporativa capaz de influenciar positivamente na performance econômica da empresa. Watts; Zimmerman (1986, p. 312) apontam a auditoria independente como uma das formas de monitorar contratos, uma vez que são responsáveis por verificar se os cálculos dos números contábeis -efetuados pelos gestores- observaram procedimentos aceitos pelo mercado e pelos órgãos reguladores.

A auditoria independente é um importante agente de Governança Corporativa para os proprietários de todos os tipos de empresas, uma vez que sua atribuição básica é verificar se as demonstrações contábeis refletem adequadamente a 
realidade da empresa (Código das Melhores Práticas do Instituto Brasileiro de Governança Corporativa, Item 4.01).

O valor da auditoria independente, enquanto mecanismo de Governança, está ligado a sua capacidade de evidenciar o que pode reduzir custos de agência, na medida em que tem alta probabilidade de detectar desvios de contratos e reportá-los. A probabilidade de reportar é dependente da probabilidade de descobrir e da probabilidade de reportar o que descobriu. A primeira, probabilidade de descobrir, relaciona-se a competência do auditor; enquanto a segunda, probabilidade de reportar, relaciona-se com sua independência em relação a empresa auditada (WATTS; ZIMMERMAN, 1986, p. 314).

As empresas de auditoria independente de maior porte possuem auditores supostamente mais capacitados. Pelo número de clientes que possuem, podem absorver com mais facilidade as perdas de receitas decorrentes de uma represália por parte dos gestores, substituindo-os, quando reportam alguma irregularidade. Dessa forma, são tidas como mais independentes.

Empresas que contratam auditorias com reputação de competência e independência estão, na verdade, emitindo um sinal de transparência ao mercado e reduzindo a assimetria de informações entre os gestores e os investidores.

Se são supostamente mais competentes e mais independentes as empresas maiores deveriam estar associadas a melhores performances das empresas onde atuam. Assim, formula-se a seguinte hipótese:

H6: Companhias auditadas por empresas integrantes das chamadas BIG $5^{59}$ tendem a ter melhor performances econômica.

${ }^{59}$ Grupo de empresas de auditoria independente formado por Arthur Andersen, Ernst \& Young, Price WaterHouse Coopers, Deloitte Touche Tohmatsu e KPMG. No período do estudo Arthur Andersen fazia parte do grupo de grandes empresas de auditoria independente. 


\section{Capítulo III}

\section{METODOLOGIA}

Os estudos acadêmicos empíricos de Governança Corporativa podem ser classificados, considerando-se a escolha da técnica e o objeto de estudo, como: 1) comparações internacionais de diferentes ambientes institucionais; 2) estudos de eventos de modificação de mecanismos; 3) análise de um ou mais mecanismos em corte transversal (BOREN; ODEGAARD, 2001) e 4) análise de um ou mais mecanismos com dados em painel, este último pouco freqüente. Trabalhos com a ótica de comparações internacionais têm sido capitaneados por La Porta et al. (1997, 1998, 1999, 2000). Os demais itens (2, 3 e 4) utilizam dados de um mesmo país, portanto, sob as mesmas condições do ambiente institucional. O presente estudo insere-se no item 4.

Sob a ótica de tipologia de estudo, este trabalho tem abordagem com características empírico-analíticas (Martins, 1994, p. 26), apoiado na técnica estatística de dados em painel ou séries temporais em corte transversal (Time Series Cross Section)

\subsection{ORIGEM DOS DADOS}

Os dados do estudo são da população de empresas de capital aberto do Brasil com ações na Bolsa de Valores de São Paulo. A amostra é do tipo não probabilístico 
ou intencional, podendo não ser, portanto, representativa da população.

A opção por esse tipo de amostra, em detrimento de uma amostra probabilística, baseia-se na necessidade da existência de liquidez dos papéis das empresas objeto de estudo, a fim de obter-se medidas de performance econômica que se valem dos preços de ações em bolsa, menos suscetíveis às variações de preços de larga amplitude, ocasionadas por períodos descontínuos de negociação dos papéis.

A amostra para o estudo constituiu-se do conjunto união das companhias que integraram o Índice Brasil - IBX ${ }^{60}$, da Bolsa de Valores de São Paulo, no período de setembro a dezembro do ano 2000 ou o índice IBX no período de setembro a dezembro do ano 2001. Em outras palavras, representa todas as companhias do índice IBX do período de setembro a dezembro do ano 2001, mais as companhias que fizeram parte do IBX no período de setembro a dezembro do ano 2000 e que não se repetiram no índice no mesmo período do ano seguinte. O Índice Brasil - IBX é composto de 100 ações e não de 100 companhias, o que implica dizer que uma mesma companhia pode aparecer mais de uma vez na carteira teórica que o constitui. Dessa forma, o número de companhias da amostra, consideradas as empresas que integraram o Índice nos últimos quadrimestres dos anos 2000 e 2001, reduziu-se a 88. Deduziu-se empresas que não possuíam dados disponíveis suficientes e empresas financeiras, razão pela qual a amostra foi reduzida novamente totalizando assim 73 empresas. A coleta de dados das 73 empresas finais permitiu reunir um total de 267 observações. A TABELA 1 apresenta o demonstrativo da formação da amostra.

Os dados foram coletados dos demonstrativos financeiros e informações anuais enviados pelas empresas à Comissão de Valores Mobiliários e disponíveis para

${ }^{60} \mathrm{O}$ Índice Brasil - IBX é um índice de preços que mede o retorno de uma carteira teórica composta por 100 ações selecionadas entre as mais negociadas na Bolsa de Valores de São Paulo BOVESPA, em termos de número de negócios e volume financeiro, ponderadas no índice pelo seu respectivo número de ações disponíveis à negociação no mercado. Arbitrariamente fixado em 1.000 pontos para a data de 28 de dezembro de 1995, o IBX - Índice Brasil teve sua divulgação iniciada em 02 de janeiro de 1997. 
consulta no site da Bolsa de Valores de São Paulo (415 DFP e 415 IAN). Também se coletou dados do provedor de informações ECONOMATICA.

Considerou-se, na escolha da amostra, os aspectos número de negócios, volume financeiro e número de ações disponíveis à negociação no mercado. Fatores esses considerados pelo Índice Brasil - IBX e importantes para a pesquisa, face incluir-se no modelo estatístico variáveis vinculadas ao mercado acionário. Caso nossa amostra incluísse empresas cujos papéis possuem pouca liquidez no mercado, as medidas de performance que utilizam preços de ações como valor de mercado adicionado, razão entre preço de mercado e valor patrimonial das ações e Tobin's Q, seriam prejudicadas, pois poder-se-ia considerar um valor para as ações, na inexistência de negócios, que não refletiriam seu verdadeiro valor.

TABELA 1 - DEMONSTRATIVO DA FORMAÇÃO DA AMOSTRA DO ESTUDO

\begin{tabular}{l|c}
\hline \multicolumn{1}{c|}{ Descrição } & Número \\
\hline Ações de empresas integrantes do IBX - set/dez 2000 & 100 \\
\hline Empresas com dois tipos de ações no IBX - set/dez 2000 & $(23)$ \\
\hline Empresas que passaram a integrar o IBX - set/dez 2001 & 11 \\
\hline Subtotal & 88 \\
\hline Eliminações de empresas financeiras e sem dados suficientes & 15 \\
\hline Total de empresas da amostra & 73 \\
\hline
\end{tabular}

\subsection{VARIÁVEIS E DEFINIÇÕES OPERACIONAIS}

Neste tópico apresentam-se as definições operacionais das variáveis utilizadas no estudo.

Uma definição operacional é um procedimento que atribui um significado comunicável a um conceito, através da especificação de como o conceito é aplicado dentro de um conjunto específico de circunstâncias. De uma outra forma, uma definição operacional é uma descrição de o que algo é e de como se obtém um valor 
para esse algo que se está tentando medir, ou seja, de como medi-lo. Uma definição operacional tem que ser específica, concreta, mensurável e útil para as pessoas envolvidas (www.ime.unicamp.br/).

$\mathrm{O}$ uso de definições operacionais remove ambigüidades, de tal forma que todas as pessoas envolvidas tem o mesmo entendimento e medem da mesma forma a característica em questão. Um componente importante de uma definição operacional é a especificação do processo de medição a ser utilizado. O físico Percy Bridgeman (1927, p. 7) foi um dos primeiros a indicar que um conceito não tem qualquer significado comunicável até que se saiba como ele será utilizado numa aplicação ou operação específica. A definição operacional de um conceito irá mudar de acordo com a aplicação. Por exemplo, o termo "limpo" terá significados bastante distinto numa residência e numa sala de cirurgia de hospital. Portanto, geralmente, é melhor pensar em definições operacionais úteis ou inúteis ao invés de definições operacionais corretas ou incorretas. A utilização de definições operacionais irá eliminar as discordâncias sobre os significados dos termos, enquanto fonte de confusão ou conflito nas relações (www.ime.unicamp.br/).

No estudo, utilizam-se cinco variáveis representativas de medida de performance econômica das empresas integrantes da amostra. Essas variáveis constituirão as variáveis dependentes dos modelos estatísticos propostos para testar as hipóteses formuladas.

Não há consenso sobre o uso de uma variável dependente como medida de performance (DAYLY; DALTON, 1993, p. 71). Winer; Mahoney (1981, p. 456) observam que o número de medidas de performance que poderia servir como variável dependente é quase infinito. Aludem, ainda, que mais importante do que a escolha de uma medida específica é o uso de múltiplas medidas. Chakravarthy (1986) e Mathiesen (2002, cap. 5) abordam as vantagens e desvantagens das principais medidas medidas de performance. $\mathrm{O}$ uso de cinco variáveis representativas de performance 
neste estudo considera, portanto, considerada as observações desses autores e segue trabalhos como os de Mathiesen (2002), Coles (2001), Bohren; Odegaard (2001), Dalton; Rechner (1991), Rhoades; Recher; Sundaramurthy (2000), Baliga; Moyer; Rao e Bhagat; Black (1999).

A seguir são apresentadas cada uma dessas variáveis com suas respectivas definições operacionais:

- $\quad$ MVA, que representa o MVA $^{\circledR}$ - Market Value Added de cada empresa, calculado da seguinte forma: $\mathrm{MVA}^{\circledR}=\mathrm{VM}$ - PL, onde: VM (valor de mercado) é a cotação das ações da empresa no último dia do ano multiplicada pelo total de ações no mercado e PL é o patrimônio líquido ao final do ano anterior. VM (valor de mercado) é indicador do provedor de informações econômico-financeiras ECONOMATICA;

- $\quad$ P_VPA, que representa o quociente entre o preço da ação da empresa na Bolsa de Valores de São Paulo e o valor patrimonial no último dia do ano. Esse indicador foi obtido do provedor de informações econômicofinanceiras ECONOMATICA;

- Tobin's Q, que representa o quociente entre o FV (firm value) e o valor dos ativos totais da empresa, relativos ao final do ano considerado. FV expressa a cotação das ações da empresa no último dia do ano multiplicada pelo total de ações no mercado, mais debêntures de curto e longo prazo, mais financiamentos de curto e longo prazos, mais adiantamento de contratos de câmbio e menos disponibilidades. FV é indicador do provedor de informações econômico-financeiras ECONOMATICA;

- Rent_Ati, que representa a rentabilidade do ativo da empresa e é expressa pela razão entre o lucro líquido (LL) do exercício considerado e o ativo total do fim do exercício anterior ao considerado; 
- Rent_PL, que representa a rentabilidade do patrimônio líquido (PL) da empresa e é expressa pela razão entre o lucro líquido (LL) do exercício considerado e o PL do fim do exercício anterior ao considerado.

As variáveis independentes são relativas aos mecanismos de Governança Corporativa objeto do estudo e referem-se à concentração de propriedade, às características do conselho de administração, ao capital votante, à política de remuneração do diretor presidente, à política financeira e ao controle interno. As definições operacionais dessas variáveis são apresentadas a seguir, separadas por mecanismo.

Para o mecanismo de Governança Corporativa concentração de propriedade, utilizam-se as variáveis explicativas Owner_1, Owner_12, Owner_13, Owner_14 e Owner_15, com as seguintes definições:

- Owner_1 representa a fração do capital da empresa que dá direito a voto, expressa em percentual, possuída pelo maior acionista controlador;

- Owner_12 representa a fração do capital da empresa que dá direito a voto, expressa em percentual, possuída pelos dois maiores acionistas controladores;

- Owner_13 representa a fração do capital da empresa que dá direito a voto, expressa em percentual, possuída pelos três maiores acionistas controladores;

- Owner_14 representa a fração do capital da empresa que dá direito a voto, expressa em percentual, possuída pelos quatro maiores acionistas controladores;

- Owner_15 representa a fração do capital da empresa que dá direito a voto, expressa em percentual, possuída pelos cinco maiores acionistas 
controladores.

Para o mecanismo de Governança Corporativa características do conselho de administração, utilizam-se as variáveis explicativas Ca_num, Ca_dir e D1_chair, com as seguintes definições:

- Ca_num representa o número de integrantes do conselho de administração;

- Ca_dir representa o percentual de integrantes do conselho de administração que também fazem parte da diretoria executiva. É a razão entre o número de profissionais que são diretores, incluso o diretor presidente, e que também compõem o conselho de administração e o número total de componentes do conselho de administração;

- D1_chair é uma variável dummy, utilizada para indicar quando a presidência do conselho de administração e da diretoria executiva são exercidas pela mesma pessoa. A variável assume valor 1 quando a presidência do conselho de administração e a presidência da diretoria executiva são exercidas pela mesma pessoa e 0 quando as duas presidências forem exercidas por pessoas distintas.

Para o mecanismo de Governança Corporativa capital votante, utiliza-se a variável explicativa Pert_ao, que representa o percentual do capital da empresa lastreado em ações ordinárias nominativas. É, portanto, a razão entre o número de ações ordinárias nominativas da empresa e número total de ações da companhia.

Para o mecanismo de Governança Corporativa política de remuneração da diretoria executiva, utilizam-se as variáveis explicativas D2_lucro e Remun_a, com as seguintes definições:

- D2_lucro é uma variável dummy, utilizada para indicar quando há participação dos administradores nos lucros da empresa. A variável 
assume valor 1 quando os administradores têm participação nos lucros auferidos e valor 0 quando não possuem participação nos lucros, isto é, quando a remuneração dos executivos independe dos lucros gerados pela companhia;

- Remun_a representa a remuneração anual total dos administradores, expressa em milhares de reais.

Para o mecanismo de Governança Corporativa política financeira, utilizamse as variáveis explicativas Deb_Asst, Div_pric e Div_earn, com as seguintes definições operacionais:

- Deb_Asst representa a razão entre o total de recursos de terceiros e o total de ativos da empresa ao final do exercício anterior ao considerado;

- Div_pric (dividend yield) representa a razão entre os dividendos pagos e o preço da ação mais líquida da empresa na Bolsa de Valores de São Paulo. Os dividendos pagos referem-se ao período anterior ao considerado e o preço da ação é o do último dia de negociação do período anterior ao considerado;

- Div_earn (pay out) representa a razão entre os dividendos propostos na DOAR - Demonstração das Origens e Aplicações de Recursos e o lucro líquido do período anterior ao considerado.

Para o mecanismo de Governança Corporativa controle interno, utiliza-se a variável explicativa D3_audit, que é uma variável dummy, utilizada para indicar quando a empresa de auditoria externa, que presta serviços a companhia, for Arthur Andersen, Deloitte Touche Tohmatsu, Ernst \& Young, KPMG, Price Waterhouse ou Coopers \& Lybrand. A variável assume valor 1 quando a companhia foi auditada por uma dessas empresas e 0 quando a empresa de auditoria externa que auditou foi outra.

Como variável de controle utiliza-se a variável explicativa Tamanho, para 
representar o tamanho da empresa, expresso pelo seu total de ativos ao final do período anterior ao período considerado. Essa variável foi transformada para o seu logaritmo, com o objetivo de obter-se escala de menor amplitude. O tamanho da empresa como variável de controle é freqüente nos estudos de Governança Corporativa, como por exemplo Bohren; Odegaard (2001) e Coles (2001). A não inclusão dessa variável no modelo poderia gerar erro de especificação, que ocasionaria estimativas enviesadas dos parâmetros.

\subsection{TÉCNICA ESTATÍSTICA}

Os estudos empíricos sobre o tema Governança Corporativa têm sido procedidos com a técnica de regressão linear, com dados em corte transversal. São exemplos os estudos de Silveira, (2002), Coles, (2001), Mathiesen, (2002) e Petra, (2002). A aplicação da técnica em dados de corte transversal limita a pesquisa a períodos estanques, perdendo-se a possibilidade de analisar os efeitos das variáveis atinentes à Governança Corporativa através dos períodos de tempo. Uma alternativa seria aplicar aos estudos técnicas de séries temporais. Isso, contudo, limitaria o estudo a medida que não permite a análise do efeito conjunto de mais de uma empresa e suas possíveis particularidades. A solução, então, seria o emprego de uma técnica que pudesse tratar dados em corte transversal combinados com dados em série temporal. Econometristas e estatísticos vêm se dedicando ao estudo e aprimoramento de técnicas capazes de tratar dados com essas características. Para uma introdução sobre o tema veja-se Hill; Griffiths; Judge (2003, cap. 17) e Kmenta (1994, cap. 12). Hsiao (1986, 2002), Maddala (1993), Baltagi (1995), Greene (2000, cap. 14) e Wooldridge (2002) aprofundam o tema. A técnica é inovadora no campo da econometria (GREENE, p. 558; HSIAO, 2002, p. XVIII)) e os pesquisadores já começam a valer-se dela, na medida em que alguns programas especializados em estatística passaram a oferecer a 
possibilidade de seu uso. Os programas LIMDEP, STATA, SAS, EVIEWS são alguns dos que já dispõem de tal técnica.

Dados coletados para estudos mediante o uso de técnicas estatísticas podem estar associados a uma mesma entidade (família, país, estado, empresa...) considerada em diversos períodos de tempo, constituindo as séries temporais, ou a diversas entidades consideradas no mesmo período de tempo, denominados dados em corte transversal.

Uma técnica estatística conhecida como Panel Data ou TSCS - Time Series Cross Section, combina dados de corte transversal com dados de séries temporais com tratamento estatístico simultâneo, e oferece diversas vantagens aos pesquisadores. Baltagi (1995) cita, como vantagens dessa técnica, a possibilidade de controlar a heterogeneidade das entidades pesquisadas (famílias, países, empresas têm características diferentes que merecem ser controladas individualmente), a obtenção de maiores graus de liberdade, maior variabilidade, menor colinearidade entre as variáveis e dados mais informativos, que conduzem a parâmetros estimados mais confiáveis, dentre outras.

Dados em painéis podem caracterizar-se por um conjunto de dados relativos a $\mathrm{N}$ entidades em $\mathrm{T}$ períodos de tempo, em que há observações para todas as entidades em todos os períodos. Dados em painéis dessa natureza são conhecidos como painéis balanceados ou completos. Quando o conjunto de dados tem omissões de observações, de uma entidade em um ou mais períodos de tempo, diz-se que o painel é não balanceado ou incompleto.

Este estudo analisa dados em painel do tipo não balanceado, com omissões relativas a períodos de tempo para algumas empresas. No entanto, os dados existem para, pelo menos, dois anos de cada empresa pesquisada.

Neste estudo de Governança Corporativa, a técnica que combina dados em corte transversal e de séries temporais será utilizada, almejando-se obter maior 
precisão nos resultados e maior poder explicativo das variáveis. Para aplicação da técnica, serão utilizados os programas EVIEWS e SAS.

\subsubsection{Modelo geral}

O modelo geral da técnica estatística dados em painel ou TSCS - Time Series Cross Section pode ser expresso por:

$$
y_{i t}=\alpha+\sum_{k=1}^{k} x_{i t k} \beta_{k}+u_{i t}
$$

onde $\mathrm{i}=1, \ldots \mathrm{N}, \mathrm{N}$ representando famílias, países, empresas, etc... cujos dados são coletados para análise. Constituem a dimensão dos dados em corte transversal;

$\mathrm{t}=1, \ldots \mathrm{T}, \mathrm{T}$ representando série temporal, ou seja, os períodos em que são coletados dados para análise;

$\alpha$ é um escalar;

$\beta_{\mathrm{k}}$ representa os coeficientes das k variáveis independentes;

$\mathrm{X}$ itk representa as variáveis independentes;

$\mathrm{u}_{\mathrm{it}}$ representa o erro aleatório.

O modelo geral de dados em painel pode originar diversas variantes da técnica mediante a especificação, em especial, do componente de erro, inclusão de variáveis defasadas e inclusão de variáveis binárias. São exemplos dessas variantes, os modelos de componentes de erro de efeitos fixos, de efeitos randômicos, em uma ou duas direções, os modelos de regressões aparentemente não relacionadas e os modelos dinâmicos de dados em painel. 
Faz-se alusão, a seguir, somente a modelos de erro, por ser a técnica aplicada ao estudo.

\subsubsection{Modelos de componentes de erro}

Os modelos de componentes de erro caracterizam-se pela especificação do termo aleatório $\mathrm{u}_{\mathrm{it}}$, de forma a considerar diferenças individuais nas diferentes entidades e nos diferentes períodos estudados.

Para considerar as diferenças individuais entre as entidades estudadas (empresas neste estudo), de forma a poder combinar todos os dados de cortes transversais e séries temporais para fins de estimação dos parâmetros e inferências, o erro aleatório $u_{i t}$ é decomposto em duas partes a saber:

$$
\mathrm{u}_{\mathrm{it}}=\mu_{\mathrm{i}}+\mathrm{v}_{\mathrm{it}}
$$

Dessa forma, o modelo passa a ser:

$$
y_{i t}=\alpha+\sum_{k=1}^{k} x_{i t k} \beta_{k}+\mu_{i}+v_{i t}
$$

$\mathrm{O}$ erro $\mu_{\mathrm{i}}$ é um erro aleatório, não observável, que responde por diferenças individuais no comportamento das empresas e é específico para cada empresa, isto é, varia de empresa para empresa, mas é invariável no tempo. Isso é representado pelo subscrito “i” em $\mu$. O erro $v_{\text {it }}$ é o erro global da regressão.

Esse modelo é conhecido como modelo de componentes de erro de uma direção.

Outro modelo de componentes de erro pode ser obtido pela inserção de um novo erro, para captar diferenças entre os períodos observados. O termo de erro global é decomposto em três elementos: 


$$
\begin{aligned}
& \mathrm{u}_{\mathrm{it}}=\mu_{\mathrm{i}}+\lambda_{\mathrm{t}}+v_{\mathrm{it}} \text { e o modelo passa a ser } \\
& y_{i t}=\alpha+\sum_{k=1}^{k} x_{i k} \beta_{k}+\mu_{i}+\lambda_{t}+v_{i t}
\end{aligned}
$$

Os erros $\mu_{\mathrm{i}}$ e $v_{\text {it }}$ são idênticos ao modelo anterior e $\lambda_{\mathrm{t}}$ representa um componente de erro que capta as diferenças intertemporais das diferentes empresas. Atente-se para o subscrito "t" que denota a possibilidade de variação do erro de período para período sem, contudo, variar de empresa para empresa.

Esse modelo é conhecido como modelo de componentes de erro em duas direções.

Nos modelos de componentes de erro (3.2.1) e (3.2.2) os erros $\mu_{\mathrm{i}}$ e $\lambda_{\mathrm{t}}$ podem ser considerados parâmetros fixos a serem estimados com $v_{\text {it }} \sim \operatorname{IID}\left(0, \sigma_{v}^{2}\right)$. Com essa especificação, o modelo é dito de efeitos fixos e é apropriado para a pesquisa de um conjunto específico de entidades como por exemplo famílias, países ou empresas. O modelo, com essa especificação, não permite inferências sobre a população. $O$ método de mínimos quadrados ordinários pode ser utilizado para estimar os parâmetros desse modelo.

Os erros $\mu_{\mathrm{i}}$ e $\lambda_{\mathrm{t}}$ dos modelos de componentes de erro (3.2.1) e (3.2.2) também podem ser considerados randômicos com $\mu_{\mathrm{i}} \sim \operatorname{IID}\left(0, \sigma_{\mu}^{2}\right), \lambda_{\mathrm{t}}\left(0, \sigma^{2} \lambda\right)$ e $v_{\text {it }} \sim$ $\operatorname{IID}\left(0, \sigma^{2}\right)$ e todos independentes entre si. Essa especificação caracteriza o modelo de componentes de erro de efeitos randômicos, indicado quando se trabalha com amostras aleatórias representativas de grandes populações, e permite inferências sobre a população. O método de mínimos quadrados generalizados é utilizado para estimar os parâmetros desse modelo.

Em suma, pode-se trabalhar com modelos de componentes de erro:

- de efeitos fixos com uma direção; 
- de efeitos fixos com duas direções;

- de efeitos randômicos com uma direção;

- de efeitos randômicos com duas direções.

A escolha do modelo a ser utilizado em um estudo recai sobre dois aspectos. Um de natureza lógica e outro de natureza técnica. A consideração lógica a ser feita é se deseja-se fazer inferências sobre uma população ou se deseja-se estudar um grupo específico de entidades. Se o objetivo é inferir sobre uma população e é possível obter amostra representativa dessa população, os modelos de efeitos randômicos podem ser utilizados. Caso contrário, os modelos de efeitos fixos são indicados. Quanto ao aspecto técnico, é possível testar qual dos modelos produz melhores estimadores não enviesados e eficientes. Os testes de Hausman e Breush-Pagan podem ser utilizados para esse fim.

No presente estudo, o aspecto de natureza lógica sugere a utilização de modelos de componentes de erros de efeitos fixos, porque as empresas objeto do estudo não constituem uma amostra representativa da população de empresas brasileiras. No entanto, o teste de Hausman será feito para corroborar, ou não, esse entendimento.

\subsubsection{Testes}

Para decidir-se sobre a aceitação das hipóteses formuladas neste estudo, examinar a qualidade dos parâmetros estimados e testar a especificação dos modelos, serão utilizados os seguintes testes:

- Teste de Student (t)

O teste "t", para dados em painel, não tem diferença em relação ao empregado em outras regressões e será utilizado para testar a significância estatística 
de cada parâmetro estimado, isoladamente.

- Teste "F"

Serão utilizados dois testes "F". O primeiro será o teste "F" que se utiliza em outras regressões, para testar a nulidade conjunta de todos os parâmetros estimados. O segundo teste "F" será utilizado para testar a hipótese de nulidade conjunta de todos os parâmetros fixos estimados e do intercepto. Esse segundo teste utiliza as seguintes fórmulas:

$$
F=\frac{(R R S S-U R S S) /(N-1)}{U R S S /(N T-N-K)} \text { para efeitos fixos de uma direção (BALTAGI, }
$$

(BALTAGI, p. 29)

$$
F=\frac{(R R S S-U R S S) /(N+T-2)}{U R S S /(N-1)(T-1)-K)} \quad \text { para efeitos fixos de duas direções }
$$

onde,

RRSS representa a soma dos quadrados dos resíduos restritos, obtidos da estimação dos parâmetros sem as restrições de $\mu_{\mathrm{i}} \mathrm{e} \lambda_{\mathrm{t}}$;

URSS representa a soma dos quadrados dos resíduos não restritos, obtidos da estimação dos parâmetros com as restrições de $\mu_{\mathrm{i}}$ e $\lambda_{\mathrm{t}}$;

$\mathrm{N}$ representa o número de entidades, no caso empresas, consideradas no corte transversal;

$\mathrm{T}$ representa o número de períodos, no caso anos, considerados na série temporal;

N-1 representa o número de graus de liberdade do numerador;

$\mathrm{NT}-\mathrm{N}-\mathrm{K}$ representa o número de graus de liberdade do denominador.

- Teste de Durbin-Watson para dados em painel

Para testar a existência de autocorrelação dos resíduos será utilizado o teste de Durbin-Watson, adaptado para dados em painel por Bhargava; Franzini; 
Narendranathan (1982). A estatística "d" é calculada da seguinte forma:

$$
d_{p}=\frac{\sum_{i=1}^{N} \sum_{t=2}^{T}\left(\tilde{u}_{i t}-\tilde{u}_{i t-1}\right)^{2}}{\sum_{i=1}^{N} \sum_{t=1}^{T} \tilde{u}_{i t}{ }^{2}}
$$

onde,

$\tilde{u}$ representa os resíduos da regressão estimada com os dados transformados pela diferença das médias individuais das entidades, no caso empresas;

$\mathrm{N}$ representa o número de entidades, no caso empresas, consideradas no corte transversal e

T representa o número de períodos, no caso anos, considerados na série temporal.

- Teste de Hausman, para efeitos fixos ou randômicos

O teste de especificação de Hausman (1978) ou estatística "m” compara a consistência e eficiência dos estimadores de mínimos quadrados ordinários (utilizado no modelo de efeitos fixos) e o modelo de regressão linear generalizado (utilizado no modelo de efeitos randômicos).

Considere-se dois estimadores $\hat{\beta}_{a}$ e $\hat{\beta}_{b}$ sob a hipótese nula de que ambos são consistentes, mas somente $\hat{\beta}_{a}$ é assintoticamente eficiente. Sob a hipótese alternativa de que somente $\widehat{\beta}_{b}$ é consistente. A estatística “m” é dada por:

$$
m=\left(\hat{\beta}_{b}-\hat{\beta}_{a}\right)^{\prime}\left(\hat{\mathbf{S}}_{b}-\hat{\mathbf{S}}_{a}\right)^{-}\left(\hat{\beta}_{b}-\hat{\beta}_{a}\right)
$$

onde $\hat{\mathbf{S}}_{b}$ e $\hat{\mathbf{S}}_{a}$ são estimativas consistentes da matriz de covariância assintótica de $\widehat{\beta}_{a}$ e $\widehat{\beta}_{b}$. Então "m" é distribuído $\chi^{2}$ com $\mathrm{k}$ graus de liberdade, onde k é a dimensão de $\hat{\beta}_{a}$ e $\hat{\beta}_{b}$ (MANUAL SAS, cap. 20). 


\subsubsection{Heterocedasticidade e autocorrelação}

Baltagi (1995, p. 77) observa que a presença de heterocedasticidade em dados em painel produz estimativas de parâmetros consistentes, porém não eficientes. Também produz erros padrões enviesados, afetando os testes que utilizam esses erros. O mesmo autor, à p. 81, chama a atenção para o mesmo problema quando há presença de autocorrelação.

Nos modelos propostos neste estudo, a heterocedasticidade é esperada, porque trabalha-se com empresas que podem ser afetas de forma distinta por diversas variáveis, como por exemplo qualidade da gestão, variação cambial e interpretação de cenários futuros. Trata-se o problema da heterocedasticidade e da autocorrelação, quando presente, utilizando o estimador aproximado de White para a variância do estimador de mínimos quadrados, que utiliza a matriz robusta de variância assintótica (HILL; GRIFFITHS; JUDGE, 2003, p. 278 e WOOLDRIDGE, 2002, p. 57 e 175).

\subsection{MODELO DO ESTUDO}

O modelo do estudo é apresentado sob duas óticas, um modelo esquemático para facilitar a visualização sintética da proposta de trabalho e modelos estatísticos detalhados na forma em que as regressões serão procedidas.

\subsubsection{Modelo esquemático}

Na FIGURA 3, que representa o modelo esquemático do estudo, espera-se:

- Que as variáveis explicativas Owner_1, Owner_12, Owner_13, Owner_14 e Owner_15, representativas do mecanismo de Governança 
Corporativa "concentração de propriedade", estejam positivamente relacionadas com as variáveis de performance econômica, conforme nossa hipótese H1. Dessa forma, espera-se que incrementos na concentração de propriedade estejam relacionados a aumentos da performance econômica;

- Que as variáveis CA_NUM, CA_DIR e D1_chair estejam negativamente relacionadas com as variáveis de performance econômica, conforme nossa hipótese H2. Espera, portanto, que conselhos com maior número de participantes (CA_NUM) sejam associados a performances descendentes e conselhos menores estejam associados a performances ascendentes. Presume-se uma relação inversa entre o percentual de integrantes do conselho de administração, que são internos à empresa, e a performance econômica, isto é, quanto maior o número de participantes internos, pior será a performance. Similar comportamento é esperado para conselhos cujo presidente seja, também, o diretor presidente (D1_chair), assim, empresas com uma pessoa exercendo a presidência do conselho de administração e outra exercendo a presidência da diretoria executiva tenderão a apresentar melhor performance do que aquelas em que as duas presidências são ocupadas pela mesma pessoa;

- Que a variável PERT_AO esteja positivamente relacionada com as medidas de performance econômica, conforme nossa hipótese H3. Dessa forma, quanto maior for o percentual do capital lastreado em ações com direito de voto (PERT_AO), maior será a performance econômica da empresa;

- Que as variáveis D2_lucro e REMUN_A estejam positivamente relacionadas com as medidas de performance econômica, conforme nossa hipótese H4. Assim, espera-se que a performance econômica esteja 
diretamente associada a remuneração de executivos baseada em incentivos ligados a resultados (D2_lucro) e a remuneração total auferida pelos executivos (REMUN_A);

- Que as variáveis explicativas DEB_ASST, DIV_PRIC e DIV_EARN estejam positivamente relacionadas com as medidas de performance econômica. Isto é, espera-se que o endividamento das empresas (DEB_ASST) esteja relacionado diretamente à performance econômica e que a política de dividentos dividend yield (DIV_PRIC) e pay out (DIV_EARN) também tenham associação direta com as medidas de performance econômica;

- Que a variável dummy D3_audit esteja diretamente relacionada com as medidas de performance econômica, de acordo com nossa hipótese H6. Espera-se, portanto, que empresas auditadas por auditorias independentes que, supostamente, teriam maiores chances de encontrar e reportar problemas nas demonstrações financeiras que auditam, possuam melhor performance econômica. 


\begin{tabular}{|c|c|c|c|c|c|c|}
\hline \multirow{8}{*}{ 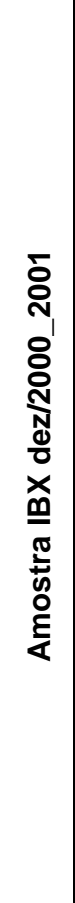 } & \multirow{8}{*}{ 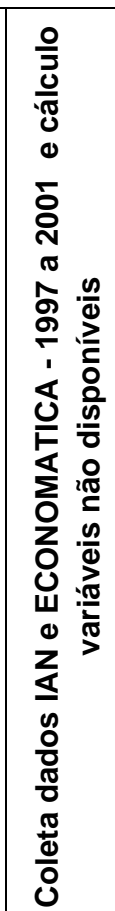 } & Mecanismos & $\begin{array}{l}\text { Variáveis } \\
\text { explicativas }\end{array}$ & $\begin{array}{c}\text { Sinal dos } \\
\text { coeficientes } \\
\text { esperados }\end{array}$ & Hipóteses & $\begin{array}{c}\text { Variáveis } \\
\text { Dependentes }\end{array}$ \\
\hline & & Concentração de propriedade & $\begin{array}{l}\text { Owner_1 } \\
\text { Owner_12 } \\
\text { Owner_13 } \\
\text { Owner_14 } \\
\text { Owner_15 }\end{array}$ & Positivos & $\mathrm{H} 1 \rightarrow$ & \multirow{7}{*}{$\begin{array}{l}\text { MVA ou } \\
\text { P_VPA ou } \\
\text { TOBIN'S Q ou } \\
\text { RENT_ATI ou } \\
\text { RENT_PL }\end{array}$} \\
\hline & & Características do CA & $\begin{array}{l}\text { CA_NUM } \\
\text { CA_DIR } \\
\text { D1_chair }\end{array}$ & Negativos & $\mathrm{H} 2 \rightarrow$ & \\
\hline & & Capital votante & PERT_AO & Positivos & $\mathrm{H} 3 \rightarrow$ & \\
\hline & & Remuneração diretoria exec . & $\begin{array}{l}\text { D2_lucro } \\
\text { REMUN_A }\end{array}$ & Positivos & $\mathrm{H} 4 \rightarrow$ & \\
\hline & & Política financeira & $\begin{array}{l}\text { DEB_ASST } \\
\text { DIV_PRIC } \\
\text { DIV_EARN }\end{array}$ & Positivos & $\mathrm{H} 5 \rightarrow$ & \\
\hline & & Controle interno & D3_audit & Positivos & $\mathrm{H} 6 \rightarrow$ & \\
\hline & & Variável de Controle & LG_TAM & Positivos & . & \\
\hline
\end{tabular}

\section{FIGURA 3 - MODELO ESQUEMÁTICO DO ESTUDO}

NOTA:

1) As variáveis independentes representam:

$M V A=$ Market Value Added.

P_VPA = quociente entre o preço da ação da empresa na Bolsa de Valores de São Paulo e o valor patrimonial no último dia do ano.

TOBIN'S Q = quociente entre o FV (firm value) e o valor dos ativos totais da empresa relativos ao final do ano.

RENT_ATI = lucro líquido (LL) do exercício considerado e o ativo total do fim do exercício anterior.

RENT_PL = razão entre o lucro líquido (LL) do exercício considerado e o PL do fim do exercício anterior.

2) As variáveis explicativas representam:

OWNER_1 = fração do capital da empresa, que dá direito a voto, possuída pelo maior acionista controlador, expressa em percentual.

OWNER_12 = representa a fração do capital da empresa, que dá direito a voto, possuída pelos dois maiores acionistas controladores, expressa em percentual.

OWNER_13 = representa a fração do capital da empresa, que dá direito a voto, possuída pelos três maiores acionistas controladores, expressa em percentual.

OWNER_14 = representa a fração do capital da empresa, que dá direito a voto, possuída pelos quatro maiores acionistas controladores, expressa em percentual.

OWNER_15 = representa a fração do capital da empresa, que dá direito a voto, possuída pelos cinco maiores acionistas controladores, expressa em percentual.

CA NUM = número de integrantes do conselho de administração.

CA_DIR = percentual de integrantes do conselho de administração que também fazem parte da diretoria executiva.

D1_chair = variável dummy utilizada para indicar quando a presidência do conselho de administração e da diretoria executiva são exercidas pela mesma pessoa. A variável assume valor 1 quando a presidência do conselho de administração e a presidência da diretoria executiva são exercidas pela mesma pessoa e 0 quando as duas presidências forem exercidas por pessoas distintas. 
PERT_AO = percentual do capital da empresa lastreado em ações ordinárias nominativas.

D2_lucro = variável dummy utilizada para indicar quando há participação dos administradores nos lucros da empresa. A variável assume valor 1 quando os administradores têm participação nos lucros auferidos e valor 0 quando não possuem participação nos lucros, isto é, quando a remuneração dos executivos independe dos lucros gerados pela companhia.

REMUN_A = remuneração anual total dos administradores expressa em milhares de reais.

DEB_ASST = razão entre o total de recursos de terceiros e o total de ativos da empresa ao final do exercício anterior.

DIV_PRIC = razão entre os dividendos pagos e o preço da ação mais líquida da empresa na Bolsa de Valores de São Paulo. Os dividendos pagos referem-se ao período anterior ao considerado e o preço da ação é do último dia de negociação do período anterior ao considerado.

DIV_EARN = razão entre os dividendos propostos na DOAR e o lucro líquido do período anterior ao considerado.

D3_audit = variável dummy utilizada para indicar quando a empresa de auditoria externa que presta serviços a companhia for Arthur Andersen, Deloitte Touche Tohmatsu, Ernst \& Young, KPMG, Price Waterhouse ou Coopers \& Lybrand. A variável assume valor 1 quando a companhia foi auditada por uma dessas empresas e 0 quando a empresa de auditoria externa foi outra.

LG_TAM = logaritmo do total de ativos ao final do período anterior ao período considerado.

3) As hipóteses formuladas são:

H1: A concentração de propriedade das empresas está positivamente relacionada com a performance econômica.

H2: A performance econômica das empresas está negativamente relacionada com o número de integrantes do conselho de administração e com o exercício duplo da presidência da diretoria executiva e do conselho de administração pela mesma pessoa e positivamente relacionada com o número de integrantes do conselho de administração que são externos a empresa.

H3: A performance econômica das empresas está positivamente relacionada com o percentual do capital lastreado em ações ordinárias nominativas.

H4: A performance econômica das empresas está positivamente relacionada com a remuneração total da diretoria executiva e com a existência de programa de participação nos lucros.

H5: A performance econômica das empresas está positivamente relacionada com o uso de capital de terceiros e com a política de dividendos praticada.

H6: Companhias auditadas por empresas integrantes das chamadas BIG $5^{61}$ tendem a ter melhor performance econômica.

\subsubsection{Modelos estatísticos}

Os modelos estatísticos, para tratamento dos dados coletados, são baseados na técnica de dados em painel com componentes de erro em uma e duas direções. Não obstante a amostra não ser aleatória e representativa da população de empresas de capital aberto brasileiras, o que pelo critério lógico sugere a aplicação da técnica sobre o pressuposto de efeitos fixos, as regressões serão efetuadas para efeitos fixos e efeitos randômicos.

${ }^{61}$ Grupo de empresas de auditoria independente formado por Arthur Andersen, Ernst \& Young, Price WaterHouse Coopers, Deloitte Touche Tohmatsu e KPMG. 
Os modelos estatísticos para efeitos fixos e randômicos de uma só direção são os seguintes:

$\mathrm{MVA}_{i t}=\alpha_{1}+\beta_{1} \mathrm{OWNER} \_1_{\mathrm{it}}+\beta_{2} \mathrm{OWNER} \_15_{\mathrm{it}}+\beta_{3} \mathrm{CA} \_$NUM $\mathrm{H}_{\mathrm{it}}+$ $\beta_{4} \mathrm{CA} \_\mathrm{DIR}$ it $+\beta_{5} \mathrm{D} 1 \_\mathrm{CHAIR}$ it $+\beta_{6} \mathrm{PERT}_{-} \mathrm{AO}_{\mathrm{it}}+\beta_{7} \mathrm{D} 2 \_\mathrm{LUCRO}_{\mathrm{it}}+\beta_{8} \mathrm{REMUN}_{-} \mathrm{A}_{\mathrm{it}}+$

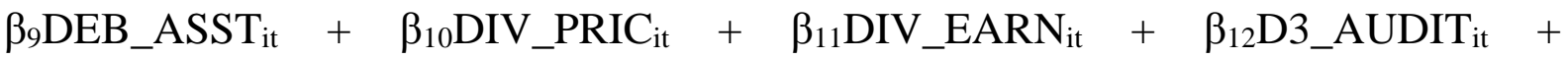
$\beta_{13} \mathrm{LG}_{-} \mathrm{TAM} \mathrm{Mit}_{\mathrm{it}}+\mu_{\mathrm{i}}+v_{\mathrm{it}}$.

P_VPA ${ }_{i t}=\alpha_{2}+\beta_{1}$ OWNER_1 $1_{i t}+\beta_{2}$ OWNER_15 $+\beta_{3}$ CA_NUM $_{\text {it }}+$

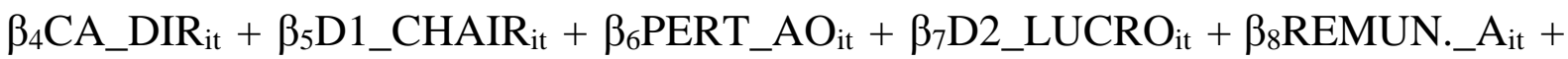

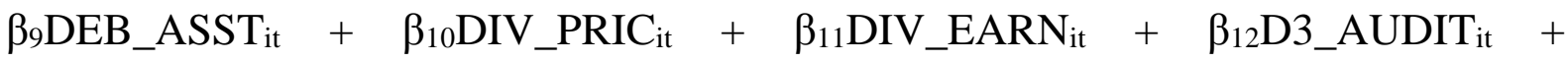
$\beta_{13} \mathrm{LG}_{-} \mathrm{TAM} \mathrm{Mit}_{\mathrm{it}}+\mu_{\mathrm{i}}+v_{\mathrm{it}}$

TOBIN'S $Q_{i t}=\alpha_{3}+\beta_{1}$ OWNER_ $1_{\text {it }}+\beta_{2}$ OWNER_15 $+\beta_{3}$ CA_NUM it $_{\text {it }}+$

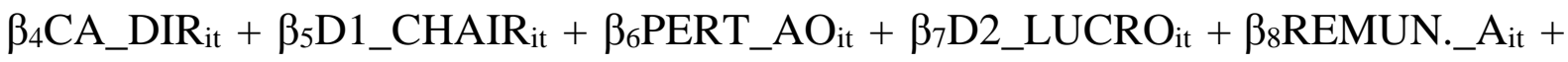

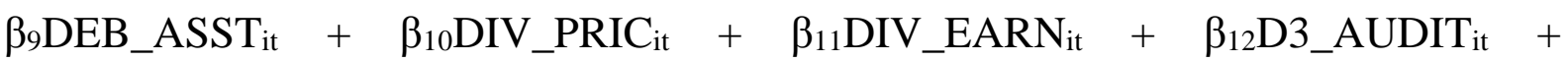
$\beta_{13} \mathrm{LG}_{-} \mathrm{TAM} \mathrm{Mit}_{\mathrm{it}}+\mu_{\mathrm{i}}+v_{\mathrm{it}}$.

RENT_ATI ${ }_{i t}=\alpha_{4}+\beta_{1}$ OWNER_1 $1_{i t}+\beta_{2}$ OWNER_15 1 it $+\beta_{3}$ CA_NUM ${ }_{\text {it }}+$

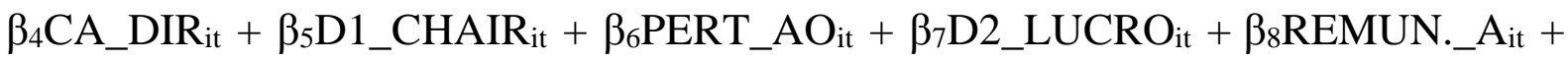

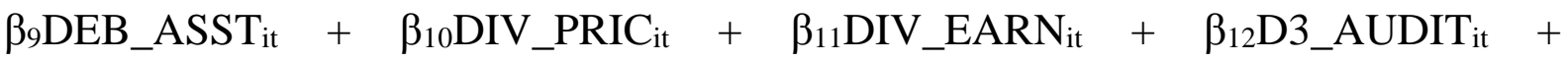
$\beta_{13} \mathrm{LG}_{-} \mathrm{TAM} \mathrm{M}_{\mathrm{it}}+\mu_{\mathrm{i}}+v_{\mathrm{it}}$

RENT_PLit $=\alpha_{5}+\beta_{1} \mathrm{OWNER} 1_{\mathrm{it}}+\beta_{2} \mathrm{OWNER} \_15_{\mathrm{it}}+\beta_{3} \mathrm{CA} \_N U M_{\mathrm{it}}+$

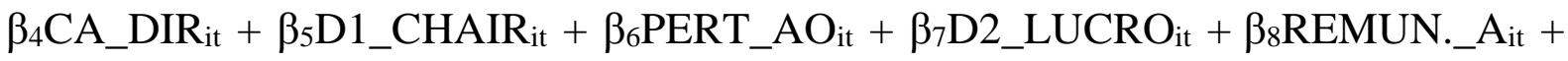

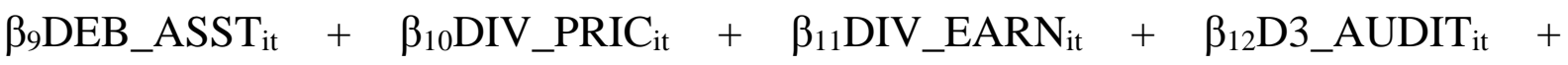
$\beta_{13} \mathrm{LG}_{-} \mathrm{TAM} \mathrm{Mit}_{\mathrm{it}}+\mu_{\mathrm{i}}+v_{\mathrm{it} .}$

Onde,

- $\mathrm{MVA}_{\text {it }}$ representa o $\mathrm{MVA}^{\circledR}$ - Market Value Added da i-ésima empresa no t-ésimo período;

- P_VPAit representa a razão entre o preço de mercado e o valor 
patrimonial da ação da i-ésima empresa no t-ésimo período;

- TOBIN'S Qit representa o quociente entre o valor dos ativos totais da iésima empresa e seu FV (firm value) relativos ao final do ano considerado, no t-ésimo período;

- RENT_ATI $\mathrm{I}_{\text {it }}$ representa a rentabilidade do ativo da i-ésima empresa no tésimo período, expressa pela razão entre o lucro líquido (LL) do exercício considerado e o ativo total do fim do exercício anterior;

- RENT_PLit representa a rentabilidade do patrimônio líquido (PL) da empresa i-ésima empresa no t-ésimo período, expressa pela razão entre o lucro líquido (LL) do exercício considerado e o PL do fim do exercício anterior ao considerado;

- $\alpha$ representa o intercepto das equações a ser estimado e é invariável de empresa para empresa e de período para período;

- $\quad \beta_{\mathrm{k}}$ representa os coeficientes angulares das equações a serem estimados com $\mathrm{k}$ variando de 1 a 13 ;

- OWNER_1 $1_{\text {it }}$ representa a fração do capital votante possuída pelo maior acionista controlador da í-ésima empresa no t-ésimo período, expressa em percentual;

- OWNER_15 it representa a fração do capital votante possuída pelos cinco maiores acionistas controladores da i-ésima empresa no t-ésimo período, expressa em percentual;

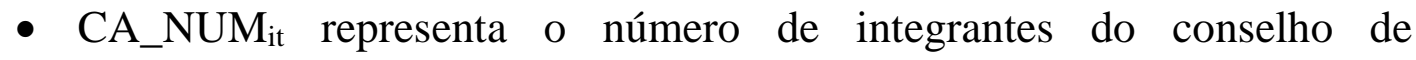
administração da i-ésima empresa no t-ésimo período;

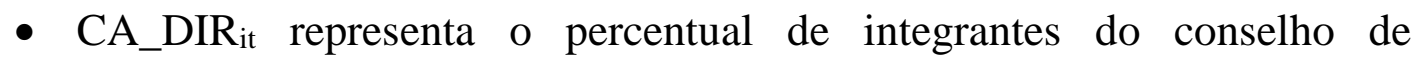
administração da i-ésima empresa no t-ésimo período, que também fazem parte da diretoria executiva; 
- D1_CHAIR it representa uma variável dummy utilizada para indicar quando a presidência do conselho de administração e da diretoria executiva da i-ésima empresa no t-ésimo período são exercidas pela mesma pessoa. A variável assume valor 1 quando a presidência do conselho de administração e a presidência da diretoria executiva são exercidas pela mesma pessoa e 0 quando for pessoa distinta;

- PERT_AO ${ }_{\text {it }}$ representa o percentual do capital da i-ésima empresa no tésimo período lastreado em ações ordinárias nominativas;

- D2_LUCRO ${ }_{\text {it }}$ representa uma variável dummy utilizada para indicar quando há participação dos administradores no lucro da i-ésima empresa no t-ésimo período. A variável assume valor 1 quando há participação e valor 0 quando não há;

- REMUN._A $A_{i t}$ representa a remuneração anual total dos administradores da i-ésima empresa no t-ésimo período, em $\mathrm{R} \$$ mil;

- DEB_ASST it representa a razão entre o total de recursos de terceiros e o total de ativos da i-ésima empresa no t-ésimo período, ao final do exercício anterior ao considerado;

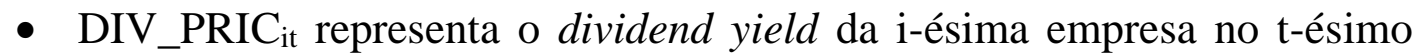
período, expresso pela razão entre os dividendos pagos e o preço da ação mais líquida. Os dividendos pagos referem-se ao período anterior ao considerado e o preço da ação é do último dia de negociação do período anterior ao considerado;

- DIV_EARN $\mathrm{it}_{\text {it }}$ representa o pay out da i-ésima empresa no t-ésimo período, expresso pela razão entre os dividendos propostos na DOAR Demonstração das Origens e Aplicações de Recursos e o lucro líquido do período anterior ao considerado; 
- D3_AUDIT it representa uma variável dummy utilizada para indicar quando a empresa de auditoria externa, que presta serviços a i-ésima empresa no t-ésimo período, é Arthur Andersen, Deloitte Touche Tohmatsu, Ernst \& Young, KPMG, Price Waterhouse ou Coopers \& Lybrand. A variável assume valor 1 quando a companhia for auditada por uma dessas empresas, 0 quando a empresa de auditoria é outra;

- LG_TAM ${ }_{\text {it }}$ representa o tamanho da empresa da i-ésima empresa no tésimo período e é expressa pelo logaritmo do total de ativos da empresa no final do período $\mathrm{t}-1$;

- $\mu_{\mathrm{i}}$ é o componente do erro que capta as diferenças individuais entre as empresas, varia de empresa para empresa mas é invariável de período para período, conforme sugere o subscrito "i”";

- $v_{\text {it }}$ é o resíduo aleatório, não observável, que representa todas as variáveis omitidas que podem afetar a variável dependente e que assumi-se como vit $\sim \operatorname{IID}\left(0, \sigma^{2}{ }_{v}\right)$.

Os modelos estatísticos para efeitos fixos e randômicos de duas direções são os seguintes:

$$
\begin{aligned}
& \text { MVA }_{i t}=\alpha_{6}+\beta_{1} \text { OWNER_1 } 1_{i t}+\beta_{2} \text { OWNER_15it }+\beta_{3} \text { CA_NUM }_{-}+
\end{aligned}
$$

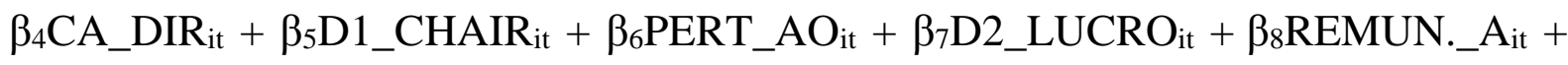

$$
\begin{aligned}
& \beta_{9} \text { DEB_ASST }_{i t}+\beta_{10} \text { DIV_PRIC }_{\mathrm{it}}+\beta_{11}{\mathrm{DIV} \_E A R N_{\mathrm{it}}}_{-}+\beta_{12} \mathrm{D}_{-} \mathrm{AUDIT}_{\mathrm{it}}+ \\
& \beta_{13} L_{-} G_{T A M}+\mu_{\mathrm{it}}+\lambda_{\mathrm{t}}+v_{\mathrm{it}} \\
& \mathrm{P}_{-} \mathrm{VPA}_{\mathrm{it}}=\alpha_{7}+\beta_{1} \mathrm{OWNER} 1_{\mathrm{it}}+\beta_{2} \text { OWNER_15 } 5_{\mathrm{it}}+\beta_{3} \mathrm{CA} \_ \text {NUM } \mathrm{it}_{\mathrm{it}}+
\end{aligned}
$$

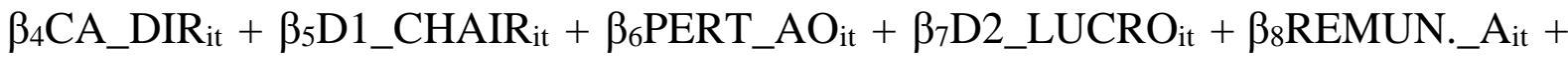

$$
\begin{aligned}
& \beta_{9} \text { DEB_ASST }_{i t}+\beta_{10} \text { DIV_PRIC }_{i t}+\beta_{11} \text { DIV_EARN }_{\mathrm{it}}+\beta_{12} \mathrm{D}_{-} \text {AUDIT }_{\mathrm{it}}+ \\
& \beta_{13} \mathrm{LG}_{-} \mathrm{TAM}_{\mathrm{it}}+\mu_{\mathrm{i}}+\lambda_{\mathrm{t}}+v_{\mathrm{it}}
\end{aligned}
$$


TOBIN'S $\mathrm{Q}_{\mathrm{it}}=\alpha_{8}+\beta_{1}$ OWNER_1 ${ }_{\text {it }}+\beta_{2}$ OWNER_15 $5_{\mathrm{it}}+\beta_{3} \mathrm{CA} \_\mathrm{NUM}_{\mathrm{it}}+$

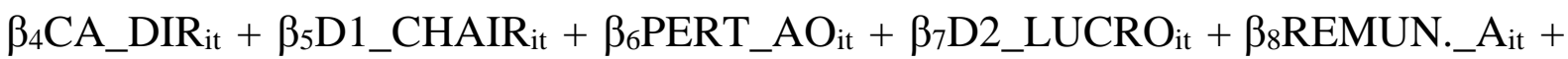
$\beta_{9}$ DEB_ASST $_{i t}+\beta_{10}$ DIV_PRIC $_{\mathrm{it}}+\beta_{11}$ DIV_EARN $_{\mathrm{it}}+\beta_{12} \mathrm{D}_{-}$AUDIT $_{\mathrm{it}}+$ $\beta_{13} L_{-}{ }_{-} \mathrm{TAM}_{\mathrm{it}}+\mu_{\mathrm{i}}+\lambda_{\mathrm{t}}+v_{\mathrm{it}}$

RENT_ATI ${ }_{i t}=\alpha_{9}+\beta_{1}$ OWNER_ $1_{\text {it }}+\beta_{2}$ OWNER_15 $5_{\text {it }}+\beta_{3}$ CA_NUM $M_{i t}+$

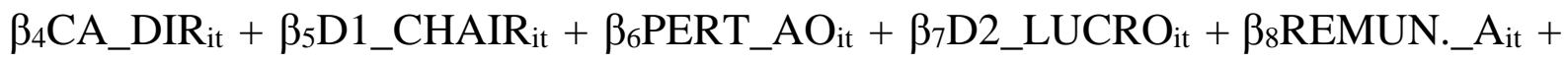
$\beta_{9}$ DEB_ASST $_{i t}+\beta_{10}$ DIV_PRIC $_{i t}+\beta_{11}$ DIV_EARN $_{\mathrm{it}}+\beta_{12} \mathrm{D}_{-}$AUDIT $_{\mathrm{it}}+$ $\beta_{13} \mathrm{LG}_{-} \mathrm{TAM}_{\mathrm{it}}+\mu_{\mathrm{i}}+\lambda_{\mathrm{t}}+v_{\mathrm{it}}$

RENT_PL $L_{i t}=\alpha_{10}+\beta_{1}$ OWNER_1 $1_{i t}+\beta_{2}$ OWNER_15 $5_{i t}+\beta_{3} C_{-} A_{-} N U M_{i t}+$ $\beta_{4}$ CA_DIR ${ }_{i t}+\beta_{5}$ D1_CHAIR ${ }_{i t}+\beta_{6}$ PERT_AO $_{i t}+\beta_{7}$ D2_LUCRO $i t+\beta_{8}$ REMUN._A $_{\text {it }}+$ $\beta_{9} \mathrm{DEB}_{-} \mathrm{ASST}_{\mathrm{it}}+\beta_{10} \mathrm{DIV}_{-}$PRIC $\mathrm{it}+\beta_{11}{\mathrm{DIV} \_E A R N_{\mathrm{it}}}+\beta_{12} \mathrm{D}_{-} \mathrm{AUDIT}_{\mathrm{it}}+$ $\beta_{13} \mathrm{LG}_{-} \mathrm{TAM}_{\mathrm{it}}+\mu_{\mathrm{i}}+\lambda_{\mathrm{t}}+v_{\mathrm{it}}$

Os modelos (4.2.6), (4.2.7), (4.2.8), (4.2.9) e (4.2.10) diferem dos modelos (4.2.1), (4.2.2), (4.2.3), (4.2.4) e (4.2.5) em relação aos componentes de erro. Os modelos (4.2.6) a (4.2.10) possuem um componente a mais $\left(\lambda_{t}\right)$ que é introduzido para captar as diferenças intertemporais dos dados de corte. Observe-se o subscrito "t", em $\lambda$, denotando que este varia no tempo mas é invariável de empresa para empresa.

\subsection{LIMITAÇÕES DO ESTUDO}

A dificuldade de obtenção de dados constituiu a primeira limitação do estudo. Variáveis que podem ser importantes para o estudo dos mecanismos de Governança Corporativa não são publicadas pelas empresas, como por exemplo: dados relativos as atividades do conselho de administração, como o número de vezes que se reúne, participação no planejamento estratégico e gestão de riscos, vínculo anterior ou algum contrato de prestação de serviços atual com a empresa que possa caracterizar os membros do conselho como não externos à empresa, ações possuídas pelo membros 
do conselho de administração e pelo diretor presidente; dados relativos aos sistemas de controle interno como auditoria interna, comitês de auditoria e de gestão de riscos; programas de incentivos dos gestores dos níveis táticos e operacionais e dos funcionários; e dados relativos a segregação de funções.

A tenra idade do tema e da base teórica, a escassez de trabalhos empíricos no Brasil e a abrangência que se quis dar ao estudo (com 6 mecanismos de Governança, 17 variáveis explicativas e 5 variáveis explicadas), devem também ser registradas.

O pressuposto implícito na modelagem, de que as variáveis representativas dos mecanismos de Governança Corporativa afetam as variáveis representativas das medidas de performance de forma exógena, não pode ser tomada como verdadeira. É possível que a performance de um período afete os períodos seguintes, e dessa forma teríamos que incluir no modelo variáveis de performance defasadas. O modelo de componentes de erros com duas direções, considerando também o efeito temporal portanto, minimiza o problema, mas a limitação merece registro ainda assim.

A amostra não probabilística, limitação imposta pela necessidade de liquidez dos papéis da empresas estudadas para que as medidas de performance econômica baseadas em mercado (MVA, P_VPA e TOBIN'S Q) fossem mais estáveis, dado que a maior liquidez reduz gaps de preços, limita as conclusões do estudo ao grupo pesquisado, não sendo possível fazer-se inferências sobre a população.

Não se pode descartar, também, limitações do estudo atinentes a erros na coleta dos dados e na mensuração das variáveis contábeis. Em que pese serem empresas abertas, com obrigatoriedade de publicar demonstrações financeiras fidedignas, a estrutura e atuação do sistema de fiscalização brasileiro deixa a desejar, o que pode dar margem a fraudes contábeis, haja visto que em ambientes institucionais sólidos como o dos Estados Unidos tais fatos ainda ocorrem. 


\section{Capítulo IV}

\section{ANÁLISE DOS RESULTADOS}

\subsection{ESTATÍSTICAS DESCRITIVAS}

$\mathrm{Na}$ TABELA 2 apresentam-se as estatísticas descritivas das cinco variáveis dependentes do estudo (MVA, P_VPA, TOBIN'S Q, RENT_ATI e RENT_PL) e das variáveis independentes (OWNER_1, OWNER_12, OWNER_13, OWNER_14, OWNER_15, CA_NUM, CA_DIR, PERT_AO, REMUN_A, DEB_ASST, DIV_PRIC, DIV_EARN e LG_TAM).

As medidas de performance econômica caracterizam-se por grande dispersão em torno de suas médias. O valor de mercado adicionado, MVA, apresentou valor mínimo de $\mathrm{R}$ \$ (49.176.817) mil, máximo de $\mathrm{R}$ \$ 32.157.718 mil e desvio padrão de $\mathrm{R} \$$ 7.102.570 mil, em torno da média de $\mathrm{R} \$$ (220.934) mil. O quociente entre o preço da ação da empresa na Bolsa de Valores de São Paulo e o valor patrimonial no último dia do ano, P_VPA, tem valor mínimo de 0,01, máximo de 25,90 e desvio padrão de 2,50, em torno da média 1,29. A medida de performance econômica TOBIN’S Q, representada pelo quociente entre o FV (firm value) e o valor dos ativos totais da empresa relativos ao final do ano, apresentou valor mínimo de 0,02 e máximo de 5,53. A média dessa medida resultou em 0,68 e o desvio padrão foi de 0,51. A rentabilidade média do ativo foi de 2,5\%, com mínimo de (36,57\%), máximo de 24,47\% e desvio padrão de $8,13 \%$. Por fim, a rentabilidade sobre o patrimônio líquido teve mínimo de 
(597,38\%), máximo de 98,63\%, média de $(0,99)$ e desvio padrão de 50,15. A expressiva dispersão dos dados em torno de suas médias pode ter sido influenciada pela variação do cenário econômico nos anos estudados (1997 a 2001), quando as taxas de câmbio e juros sofreram expressivas oscilações, invertendo fortemente suas tendência a partir de 1999, quando as taxas de juros saíram do nível médio anual de $25 \%$ a $30 \%$ para cerca de $17 \%$ ao ano e as taxas de câmbio evoluíram de cerca de 1,10 reais por dólar para o intervalo médio de 1,80 a 2,40 reais por dólar, uma vez que a amostra é composta de empresas de todos os setores da economia com variada estrutura de capital.

$\mathrm{Na}$ concentração de capital, pode-se constatar o expressivo número de empresas com forte concentração de capital acionário com direito a voto. A média de concentração em um único acionista aproximou-se de 60\%, com mínimo de 5,39\%, máximo de $100 \%$ e desvio padrão de $24,34 \%$. Quando se considerou o somatório dos cinco maiores acionistas, a média de concentração de propriedade foi ainda mais expressiva, atingindo quase 83\%; o mínimo elevou-se a $15 \%$ e o desvio padrão reduziu-se a 15,03\%. A concentração de propriedade pode ter causa nas deficiências das instituições no que concerne à proteção de acionistas minoritários e/ou no uso da concentração como mecanismo de Governança Corporativa.

No que diz respeito ao conselho de administração - mecanismo de Governança sempre presente nos estudos, palestras e seminários sobre Governança - o número de integrantes nas empresas estudadas girou em torno da média 8,83 , muito próxima ao número máximo de conselheiros recomendado pelo Instituto Brasileiro de Governança Corporativa e pelas Recomendações da CVM (Comissão de Valores Mobiliários) sobre Governança Corporativa. O número mínimo foi 3 membros, exatamente o mínimo preconizado pela Lei das S.A. Os dados evidenciaram, contudo, a existência de grandes conselhos com até 28 membros. O número de conselheiros externos à empresa, neste estudo representado por aqueles membros que não integram a diretoria executiva, mostrou-se bastante reduzido, registrando $14,86 \%$ ou 1,3 
membros em média, com registro, inclusive, de total ausência de conselheiros externos. No entanto, os dados revelaram a existência de empresas com até dois terços dos conselheiros de membros externos a empresa. Os códigos de boas práticas de Governança Corporativa recomendam presença significativa de conselheiros externos.

TABELA 2 - ESTATÍSTICAS DESCRITIVAS DE TODAS AS VARIÁVEIS DO ESTUDO

\begin{tabular}{|c|c|c|c|c|c|c|c|}
\hline \multirow{2}{*}{\multicolumn{2}{|c|}{ Estatísticas }} & \multicolumn{6}{|c|}{ VARIÁVEIS } \\
\hline & & \multirow{2}{*}{\begin{tabular}{|l|} 
MVA \\
-220.934 \\
\end{tabular}} & \multirow{2}{*}{\begin{tabular}{r|} 
P_VPA \\
1,29
\end{tabular}} & \multirow{2}{*}{\begin{tabular}{r|} 
TOBIN'S Q \\
, 68 \\
\end{tabular}} & \multirow{2}{*}{\begin{tabular}{r|} 
RENT_ATI \\
$2,50 \%$ \\
\end{tabular}} & \multirow{2}{*}{\begin{tabular}{r|} 
RENT_PL \\
,$- 99 \%$
\end{tabular}} & \multirow{2}{*}{$\begin{array}{r}\text { OWNER } \_1 \\
59,78 \%\end{array}$} \\
\hline Média & & & & & & & \\
\hline Mediana & & -118.349 & ,80 &, 57 & $2,89 \%$ & $4,27 \%$ & $57,31 \%$ \\
\hline Desvio Padrão & & 7.102 .570 & 2,50 &, 51 & $8,13 \%$ & $50,15 \%$ & $24,34 \%$ \\
\hline Mínimo & & -49.176 .817 & ,01 & ,02 & $-36,57 \%$ & $-597,38 \%$ & $5,39 \%$ \\
\hline Máximo & & 32.157 .718 & 25,90 & 5,53 & $24,47 \%$ & $98,63 \%$ & $100,00 \%$ \\
\hline \multirow[t]{5}{*}{ Percentis } & 20 & -780.404 & ,40 & ,37 & $-1,19 \%$ & $-2,39 \%$ & $41,59 \%$ \\
\hline & 40 & -213.117 & ,60 & ,49 & $1,75 \%$ & $2,70 \%$ & $51,79 \%$ \\
\hline & 50 & -118.349 & ,80 &, 57 & $2,89 \%$ & $4,27 \%$ & $57,31 \%$ \\
\hline & 60 & -8.540 & ,90 & ,65 & $4,10 \%$ & $6,59 \%$ & $60,65 \%$ \\
\hline & 80 & 685.318 & 1,50 & ,89 & $7,71 \%$ & $12,95 \%$ & $87,27 \%$ \\
\hline \multirow{2}{*}{\multicolumn{2}{|c|}{ ESTATÍSTICAS }} & \multicolumn{6}{|c|}{ VARIÁVEIS } \\
\hline & & OWNER_12 & OWNER_13 & OWNER_14 & OWNER_15 & CA NUM & CA_DIR \\
\hline Média & & $74,22 \%$ & $79,96 \%$ & $81,92 \%$ & $82,68 \%$ & 8,83 & $14,86 \%$ \\
\hline Mediana & & $73,81 \%$ & $83,98 \%$ & $85,04 \%$ & $85,30 \%$ & 8,00 & $12,50 \%$ \\
\hline Desvio Padrão & & $19,44 \%$ & $16,20 \%$ & $15,36 \%$ & $15,03 \%$ & 4,34 & $14,93 \%$ \\
\hline Mínimo & & $12,70 \%$ & $27,75 \%$ & $32,89 \%$ & $32,89 \%$ & 3,00 &, $00 \%$ \\
\hline Máximo & & $100,00 \%$ & $100,00 \%$ & $100,00 \%$ & $100,00 \%$ & 28,00 & $66,67 \%$ \\
\hline \multirow[t]{5}{*}{ Percentis } & 20 & $57,18 \%$ & $64,55 \%$ & $68,99 \%$ & $70,43 \%$ & 6,00 &, $00 \%$ \\
\hline & 40 & $70,68 \%$ & $79,63 \%$ & $82,09 \%$ & $83,78 \%$ & 7,00 & $9,09 \%$ \\
\hline & 50 & $73,81 \%$ & $83,98 \%$ & $85,04 \%$ & $85,30 \%$ & 8,00 & $12,50 \%$ \\
\hline & 60 & $82,66 \%$ & $86,33 \%$ & $87,68 \%$ & $87,71 \%$ & 9,00 & $14,29 \%$ \\
\hline & 80 & $95,19 \%$ & $97,04 \%$ & $97,32 \%$ & $97,32 \%$ & 11,00 & $28,57 \%$ \\
\hline \multirow{2}{*}{\multicolumn{2}{|c|}{ ESTATÍSTICAS }} & \multicolumn{6}{|c|}{ VARIÁVEIS } \\
\hline & & PERT_AO & REMUN_A & DEB_ASST & DIV_PRIC & DIV_EARN & LG_TAM \\
\hline Média & & $47,22 \%$ & 2,536 & $26,88 \%$ & $4,92 \%$ & $43,00 \%$ & 6,42 \\
\hline Mediana & & $39,29 \%$ & 1,717 & $26,45 \%$ & $3,07 \%$ & $33,07 \%$ & 6,37 \\
\hline Desvio Padrão & & $17,12 \%$ & 3,006 & $15,46 \%$ & $5,91 \%$ & $62,88 \%$ & ,57 \\
\hline Mínimo & & $33,33 \%$ & 500 & $0,00 \%$ & $0,00 \%$ & $0,00 \%$ & 4,82 \\
\hline Máximo & & $100,00 \%$ & 24,000 & $69,80 \%$ & $35,81 \%$ & $81,47 \%$ & 7,99 \\
\hline \multirow[t]{5}{*}{ Percentis } & 20 & $34,70 \%$ & 726 & $12,87 \%$ & $0,00 \%$ & $0,00 \%$ & 5,98 \\
\hline & 40 & $37,60 \%$ & 1,453 & $22,23 \%$ & $1,73 \%$ & $26,40 \%$ & 6,21 \\
\hline & 50 & $39,29 \%$ & 1,717 & $26,45 \%$ & $3,07 \%$ & $33,07 \%$ & 6,37 \\
\hline & 60 & $43,22 \%$ & 2,168 & $31,81 \%$ & $4,26 \%$ & $40,07 \%$ & 6,52 \\
\hline & 80 & $57,75 \%$ & 3,560 & $40,21 \%$ & $8,40 \%$ & $65,55 \%$ & 6,90 \\
\hline
\end{tabular}

NOTA:

MVA $=$ Market Value Added

P_VPA = quociente entre o preço da ação da empresa na Bolsa de Valores de São Paulo e o valor patrimonial no último dia do ano. 
TOBIN'S Q = quociente entre o FV (firm value) e o valor dos ativos totais da empresa relativos ao final do ano.

RENT_ATI = lucro líquido (LL) do exercício considerado e o ativo total do fim do exercício anterior.

RENT_PL = razão entre o lucro líquido (LL) do exercício considerado e o PL do fim do exercício anterior.

OWNER_1 = fração do capital da empresa, que dá direito a voto, possuída pelo maior acionista controlador, expressa em percentual.

OWNER_12 = representa a fração do capital da empresa, que dá direito a voto, possuída pelos dois maiores acionistas controladores, expressa em percentual.

OWNER_13 = representa a fração do capital da empresa, que dá direito a voto, possuída pelos três maiores acionistas controladores, expressa em percentual.

OWNER_14 = representa a fração do capital da empresa, que dá direito a voto, possuída pelos quatro maiores acionistas controladores, expressa em percentual.

OWNER_15 = representa a fração do capital da empresa, que dá direito a voto, possuída pelos cinco maiores acionistas controladores, expressa em percentual.

CA_NUM = número de integrantes do conselho de administração.

CA_DIR = percentual de integrantes do conselho de administração que também fazem parte da diretoria executiva.

PERT_AO = percentual do capital da empresa lastreado em ações ordinárias nominativas.

REMUN_A = remuneração anual total dos administradores expressa em milhares de reais.

DEB_ASST = razão entre o total de recursos de terceiros e o total de ativos da empresa ao final do exercício anterior.

DIV_PRIC = razão entre os dividendos pagos e o preço da ação mais líquida da empresa na Bolsa de Valores de São Paulo. Os dividendos pagos referem-se ao período anterior ao considerado e o preço da ação é do último dia de negociação do período anterior ao considerado.

DIV_EARN = razão entre os dividendos propostos na DOAR e o lucro líquido do período anterior ao considerado.

LG_TAM = logaritmo do total de ativos ao final do período anterior ao período considerado.

O capital das empresas lastreado em ações com direito a voto, por seu turno, surpreendeu, com média de 47,22\% do total de ações emitidas pelas empresas, quando a lei que vigorou até 31.10.2001, Lei número 6.404 de 15.12.1976, exigia o mínimo de um terço apenas (cerca de 33\%). Os dois extremos, mínimo de 33,33\% e máximo de $100 \%$ também foram registrados. O regulamento do Novo Mercado da Bolsa de Valores de São Paulo exige, como uma das condições para ser listada, que a totalidade das ações da empresa dêem direito a voto.

A remuneração total anual da diretoria executiva teve média de $\mathrm{R} \$ 2.536$ mil, máximo de $\mathrm{R} \$ 24.000$ mil e desvio padrão de $\mathrm{R} \$ 3.006$ mil. O valor mínimo foi de R\$ 500 mil. A remuneração de executivos é um importante mecanismo de Governança Corporativa e, geralmente, tem um componente de participação nos lucros. Infelizmente, as empresas brasileiras não reportam programas de incentivos de participação nos lucros, limitando-se a mencionar se há ou não participação dos executivos no lucros. Dados mais precisos seriam de grande valia para os estudos de 
Governança com essa variável.

Os dados relativos à política financeira revelaram uma média de endividamento, recursos de terceiros sobre ativos totais, de $26,88 \%$, empresas sem dívidas e empresas com cerca de $70 \%$ do ativo composto por recursos de terceiros. No entanto, $80 \%$ das empresas têm índice de endividamento de cerca de $40 \%$. A razão entre os dividendos pagos e o preço da ação mais líquida da empresa teve média de 4,92\%, mínimo $0 \%$ e máximo de $35,81 \%$, sendo que $80 \%$ das empresas possuem essa relação até o nível de 8,40\%. A relação dividendos propostos na DOAR e o lucro líquido do período anterior ao considerado revelou uma média de 33,07\%, mínimo de 0\% e máximo de $81,47 \%$. A política de dividendos, favorecendo a remuneração dos capitais investidos em ações, é um sinal, ao mercado de investidores, de boa prática de Governança por parte dos gestores, sendo considerado um instrumento de redução de assimetria informacional entre proprietários (acionistas) e gestores (controladores).

Por fim, o total de ativos, incluído no estudo como variável de controle por influenciar a performance, revelou uma média de $\mathrm{R} \$ 2.630 .268$ mil, mínimo de $\mathrm{R} \$$ 66.069 mil e máximo de $\mathrm{R} \$ 97.723 .722$ mil (valores equivalentes aos antilogaritmos constantes da tabela).

\subsection{MATRIZ DE CORRELAÇÕES}

Com o propósito de averiguar o relacionamento das variáveis estudadas, tomadas aos pares, elaborou-se a matriz de correlações apresentada na TABELA 3. Nas cinco primeiras colunas e nas cinco primeiras linhas aparecem as variáveis dependentes dos modelos estatísticos propostos. As demais variáveis são variáveis independentes.

Sobre as variáveis dependentes, observa-se que a correlação entre o quociente do preço da ação da empresa na Bolsa de Valores de São Paulo e o valor 
patrimonial no último dia do ano ( $\mathrm{P}_{-}$VPA) e quociente entre o FV (firm value) e o valor dos ativos totais da empresa relativos ao final do ano (TOBIN'S Q) de 0,73 sugere que se encontrarão resultados semelhantes para as regressões com essas duas variáveis como variáveis dependentes.

No que se refere às variáveis que representam a concentração de propriedade, variáveis Owner_1 a Owner_15, observa-se sinais negativos de suas correlações com as variáveis dependentes, quando esperava-se correlação positiva. Apenas as correlações de Owner_1 e Owner_12 com a variável RENT_ATI aparecem com correlações positivas, de acordo com a hipótese formulada. No entanto, os coeficientes de correlações são muito baixos, sugerindo que a concentração de propriedade pode não estar relacionada às medidas de performance econômica, exceto pelo efeito da correlação múltipla. O fato de observar-se que a maioria das correlações com as variáveis de medidas de performance são negativas e de também aparecerem correlações positivas não se distancia dos trabalhos empíricos, como se viu na revisão bibliográfica, onde Gugler (2001), em trabalhos sobre concentração de propriedade entre 1932 e 1998, encontrou 12 casos com relação positiva, 13 neutros e 2 com relação negativa.

Ainda sobre as variáveis representativas da concentração de propriedade, nota-se que a variável Owner_1, que representa a fração do capital da empresa que dá direito a voto possuída pelo maior acionista, apresenta coeficiente de correlação positivo com as variáveis Owner_12, Owner_13 e Owner_14, respectivamente a fração do capital da empresa que dá direito a voto possuída pelos dois, três e quatro maiores acionistas, superior a 0,60, razão pela qual essas variáveis serão excluídas dos modelos, a fim de evitar-se problemas de multicolinearidade.

Quanto ao conselho de administração, esperava-se uma correlação negativa, indicando que conselhos com maior número de integrantes estivessem associados a medidas de performance menores, porém, a variável que denota o número de 
conselheiros (CA_NUM) mostra-se positivamente correlacionada com MVA (Market Value Added), RENT_ATI (Rentabilidade do Ativo) e RENT_PL (Rentabilidade do PL). Por outro lado, os coeficientes de correlação com P_VPA (quociente entre o preço da ação da empresa na Bolsa de Valores de São Paulo e o valor patrimonial no último dia do ano) e TOBIN'S Q (quociente entre o FV (firm value) e o valor dos ativos totais da empresa relativos ao final do ano) são negativos, conforme esperado, e constituem os maiores coeficientes, respectivamente 0,05 e 0,13. Também a variável que representa a proporção de membros do conselho de administração que são internos à empresa (CA_DIR), mostra-se positivamente correlacionada às medidas de performance, exceto à rentabilidade do ativo (RENT_ATI), contrariamente à hipótese de que quanto maior o número de membros externos à empresa maior seria a performance econômica.

O percentual de ações do capital que dá direito a voto (PERT_AO) apresenta coeficientes de correlação negativos em relação às medidas de performance, exceto com relação à medida $\mathrm{P}_{-} \mathrm{VPA}$, quando esperava-se que quanto maior fosse $\mathrm{o}$ percentual de ações com direito a voto, maior seria a performance econômica. Nesse caso, os coeficientes são mais significativos - $(0,25)$ com MVA e $(0,10)$ com RENT_PL -, o que sugere que as regressões poderão surpreender contrariando a hipótese. Novamente é importante lembrar que esta análise restringe-se a correlação simples, enquanto o efeito nas regressões será num contexto de correlações múltiplas.

A remuneração total da diretoria executiva (REMUN_A), contrariamente à hipótese, é negativamente correlacionada com as medidas de performance P_VPA e TOBIN'S Q, porém, com coeficientes muito baixos, cerca de $(0,02)$ para as duas medidas de performance.

Para o uso de capital de terceiros, representado pela variável DEB_ASST, esperava-se uma correlação positiva com as medidas de performance econômica. Os coeficientes de correlação de 0,09 com MVA, 0,22 com P_VPA, 0,20 com TOBIN'S 
Q, $(0,28)$ com RENT_ATI e $(0,28)$ com RENT_PL são os mais expressivos da matriz, dentre as variáveis independentes, e em que pese dois dos coeficientes serem negativos (com RENT_ATI e com RENT_PL), pode-se esperar que esta variável venha a confirmar a hipótese de que o endividamento é um mecanismo de Governança Corporativa que pode estar associado a melhor performance da empresa.

O segundo melhor conjunto de coeficientes de correlação com as variáveis de medidas de performance é do dividend yield (variável DIV_PRIC) com correlação de $(0,11)$ com MVA, $(0,14)$ com P_VPA, $(0,17)$ com TOBIN'S Q, 0,17 com RENT_ATI e 0,17 com RENT_PL. À exceção dos dois últimos (RENT_ATI e RENT_PL), os demais coeficientes não correspondem à expectativa expressa na hipótese, pois previa-se que quando a razão dividendos pagos e preços das ações crescesse, também cresceria a medida de performance, isto é, haveria uma correlação positiva. É possível que os resultados das regressões também corroborem essa variável como um resultado inusitado. A outra variável também relacionada à política de dividendos (DIV_EARN), que representa o pay out das empresas, apresenta resultados análogos à variável DIV_PRIC, porém com coeficientes de menor magnitude.

A última das variáveis, incluída nos modelos como variável de controle representando o tamanho da empresa, tem coeficientes de correlação simples com as variáveis de performance instáveis, com valores oscilando entre $(0,18)$ e 0,12 . Dessa forma, é possível que se tenha resultados das regressões desde significativos e contrários a hipótese de que o tamanho está positivamente correlacionado com a performance, passando por resultados não significativos e indo até resultados significativos e confirmatórios de relacionamentos positivo entre tamanho e performance.

Por fim, a alternância dos sinais dos coeficientes de correlações simples, quando se examina cada uma das variáveis independentes em relação às cinco variáveis dependentes (em linha), sugere que o tipo de medida de performance 
econômica faz diferença nos estudos de Governança Corporativa.

TABELA 3 - MATRIZ DE CORRELAÇÕES DE TODAS AS VARIÁVEIS DO ESTUDO

\begin{tabular}{|c|c|c|c|c|c|c|}
\hline & MVA & P_VPA & TOBIN'S Q & RENT_ATI & RENT_PL & OWNER_1 \\
\hline MVA & 1,0000 & 0,2072 & 0,2967 & 0,1020 & 0,0176 & $(0,0427)$ \\
\hline P_VPA & 0,2072 & 1,0000 & 0,7333 & $(0,2969)$ & $(0,1888)$ & $(0,1029)$ \\
\hline TOBIN'S Q & 0,2967 & 0,7333 & 1,0000 & $(0,2352)$ & $(0,1531)$ & $(0,1147)$ \\
\hline RENT_ATI & 0,1020 & $(0,2969)$ & $(0,2352)$ & 1,0000 & 0,5283 & 0,0234 \\
\hline RENT_PL & 0,0176 & $(0,1888)$ & $(0,1531)$ & 0,5283 & 1,0000 & $(0,0869)$ \\
\hline OWNER_1 & $(0,0427)$ & $(0,1029)$ & $(0,1147)$ & 0,0234 & $(0,0869)$ & 1,0000 \\
\hline OWNER_12 & $(0,0928)$ & $(0,0722)$ & $(0,0638)$ & 0,0132 & $(0,0787)$ & 0,8287 \\
\hline OWNER_13 & $(0,1170)$ & $(0,0770)$ & $(0,0547)$ & $(0,0181)$ & $(0,0750)$ & 0,6789 \\
\hline OWNER_14 & $(0,1213)$ & $(0,0630)$ & $(0,0523)$ & $(0,0411)$ & $(0,0865)$ & 0,6070 \\
\hline OWNER_15 & $(0,1176)$ & $(0,0212)$ & $(0,0276)$ & $(0,0680)$ & $(0,1049)$ & 0,5749 \\
\hline $\mathrm{CA} \_\mathrm{NUM}$ & 0,0226 & $(0,0493)$ & $(0,1278)$ & 0,0451 & 0,0280 & $(0,0056)$ \\
\hline CA_DIR & 0,0069 & 0,0128 & 0,0618 & $(0,0531)$ & 0,0056 & $(0,0022)$ \\
\hline PERT_AO & $(0,2533)$ & 0,0686 & $(0,0107)$ & $(0,0240)$ & $(0,1018)$ & 0,1626 \\
\hline REMUN_A & 0,1258 & $(0,0166)$ & $(0,0241)$ & 0,1265 & 0,0116 & $(0,1377)$ \\
\hline DEB_ASST & 0,0905 & 0,2188 & 0,2019 & $(0,2788)$ & $(0,2811)$ & $(0,0545)$ \\
\hline DIV_PRIC & $(0,1063)$ & $(0,1448)$ & $(0,1742)$ & 0,1736 & 0,1531 & $(0,0150)$ \\
\hline DIV_EARN & $(0,0463)$ & $(0,0795)$ & $(0,0493)$ & 0,1174 & 0,1018 & $(0,1583)$ \\
\hline \multirow[t]{2}{*}{ LG_TAM } & $(0,1798)$ & 0,0007 & $(0,0173)$ & 0,1220 & 0,0468 & $(0,2635)$ \\
\hline & OWNER_12 & OWNER_13 & OWNER_14 & OWNER_15 & CA_NUM & CA_DIR \\
\hline MVA & $(0,0928)$ & $(0,1170)$ & $(0,1213)$ & $(0,1176)$ & 0,0226 & 0,0069 \\
\hline P_VPA & $(0,0722)$ & $(0,0770)$ & $(0,0630)$ & $(0,0212)$ & $(0,0493)$ & 0,0128 \\
\hline TOBIN'S Q & $(0,0638)$ & $(0,0547)$ & $(0,0523)$ & $(0,0276)$ & $(0,1278)$ & 0,0618 \\
\hline RENT_ATI & 0,0132 & $(0,0181)$ & $(0,0411)$ & $(0,0680)$ & 0,0451 & $(0,0531)$ \\
\hline RENT_PL & $(0,0787)$ & $(0,0750)$ & $(0,0865)$ & $(0,1049)$ & 0,0280 & 0,0056 \\
\hline OWNER_1 & 0,8287 & 0,6789 & 0,6070 & 0,5749 & $(0,0056)$ & $(0,0022)$ \\
\hline OWNER_12 & 1,0000 & 0,9097 & 0,8370 & 0,7981 & $(0,0042)$ & $(0,0194)$ \\
\hline OWNER_13 & 0,9097 & 1,0000 & 0,9686 & 0,9392 & $(0,0315)$ & $(0,0096)$ \\
\hline OWNER_14 & 0,8370 & 0,9686 & 1,0000 & 0,9857 & $(0,0648)$ & 0,0021 \\
\hline OWNER_15 & 0,7981 & 0,9392 & 0,9857 & 1,0000 & $(0,0788)$ & 0,0145 \\
\hline $\mathrm{CA} \_\mathrm{NUM}$ & $(0,0042)$ & $(0,0315)$ & $(0,0648)$ & $(0,0788)$ & 1,0000 & $(0,2580)$ \\
\hline CA_DIR & $(0,0194)$ & $(0,0096)$ & 0,0021 & 0,0145 & $(0,2580)$ & 1,0000 \\
\hline PERT_AO & 0,1100 & 0,0700 & 0,0872 & 0,0890 & $(0,0787)$ & $(0,0179)$ \\
\hline REMUN_A & $(0,1894)$ & $(0,1562)$ & $(0,1382)$ & $(0,1245)$ & $(0,0189)$ & 0,0141 \\
\hline DEB_ASST & $(0,0372)$ & 0,0077 & 0,0427 & 0,0693 & $(0,0520)$ & 0,0702 \\
\hline DIV_PRIC & $(0,0234)$ & $(0,0217)$ & $(0,0073)$ & 0,0010 & $(0,0180)$ & 0,0494 \\
\hline DIV_EARN & $(0,1044)$ & $(0,0972)$ & $(0,0908)$ & $(0,0966)$ & $(0,0711)$ & $(0,0093)$ \\
\hline \multirow[t]{2}{*}{ LG_TAM } & $(0,2574)$ & $(0,2670)$ & $(0,2559)$ & $(0,2732)$ & $(0,0174)$ & 0,0717 \\
\hline & PERT_AO & REMUN_A & DEB_ASST & DIV_PRIC & DIV_EARN & LG_TAM \\
\hline MVA & $(0,2533)$ & 0,1258 & 0,0905 & $(0,1063)$ & $(0,0463)$ & $(0,1798)$ \\
\hline P_VPA & 0,0686 & $(0,0166)$ & 0,2188 & $(0,1448)$ & $(0,0795)$ & 0,0007 \\
\hline TOBIN'S Q & $(0,0107)$ & $(0,0241)$ & 0,2019 & $(0,1742)$ & $(0,0493)$ & $(0,0173)$ \\
\hline RENT_ATI & $(0,0240)$ & 0,1265 & $(0,2788)$ & 0,1736 & 0,1174 & 0,1220 \\
\hline RENT_PL & $(0,1018)$ & 0,0116 & $(0,2811)$ & 0,1531 & 0,1018 & 0,0468 \\
\hline
\end{tabular}




\begin{tabular}{l|c|c|c|c|c|c}
\hline & PERT_AO & REMUN_A & DEB_ASST & DIV_PRIC & DIV_EARN & LG_TAM \\
\hline OWNER_1 & 0,1626 & $(0,1377)$ & $(0,0545)$ & $(0,0150)$ & $(0,1583)$ & $(0,2635)$ \\
\hline OWNER_12 & 0,1100 & $(0,1894)$ & $(0,0372)$ & $(0,0234)$ & $(0,1044)$ & $(0,2574)$ \\
\hline OWNER_13 & 0,0700 & $(0,1562)$ & 0,0077 & $(0,0217)$ & $(0,0972)$ & $(0,2670)$ \\
\hline OWNER_14 & 0,0872 & $(0,1382)$ & 0,0427 & $(0,0073)$ & $(0,0908)$ & $(0,2559)$ \\
\hline OWNER_15 & 0,0890 & $(0,1245)$ & 0,0693 & 0,0010 & $(0,0966)$ & $(0,2732)$ \\
\hline CA_NUM & $(0,0787)$ & $(0,0189)$ & $(0,0520)$ & $(0,0180)$ & $(0,0711)$ & $(0,0174)$ \\
\hline CA_DIR & $(0,0179)$ & 0,0141 & 0,0702 & 0,0494 & $(0,0093)$ & 0,0717 \\
\hline PERT_AO & 1,0000 & $(0,0762)$ & 0,0696 & 0,0667 & $(0,0132)$ & 0,2613 \\
\hline REMUN_A & $(0,0762)$ & 1,0000 & $(0,0089)$ & 0,0089 & 0,0870 & 0,2306 \\
\hline DEB_ASST & 0,0696 & $(0,0089)$ & 1,0000 & $(0,1538)$ & $(0,1308)$ & $(0,0145)$ \\
\hline DIV_PRIC & 0,0667 & 0,0089 & $(0,1538)$ & 1,0000 & 0,1985 & 0,0642 \\
\hline DIV_EARN & $(0,0132)$ & 0,0870 & $(0,1308)$ & 0,1985 & 1,0000 & 0,2251 \\
\hline LG_TAM & 0,2613 & 0,2306 & $(0,0145)$ & 0,0642 & 0,2251 & 1,0000 \\
\hline
\end{tabular}

NOTA:

MVA $=$ Market Value Added

P_VPA = quociente entre o preço da ação da empresa na Bolsa de Valores de São Paulo e o valor patrimonial no último dia do ano.

TOBIN'S Q = quociente entre o FV (firm value) e o valor dos ativos totais da empresa relativos ao final do ano.

RENT_ATI = lucro líquido (LL) do exercício considerado e o ativo total do fim do exercício anterior.

RENT_PL = razão entre o lucro líquido (LL) do exercício considerado e o PL do fim do exercício anterior.

OWNER_1 = fração do capital da empresa, que dá direito a voto, possuída pelo maior acionista controlador, expressa em percentual.

OWNER_12 = representa a fração do capital da empresa, que dá direito a voto, possuída pelos dois maiores acionistas controladores, expressa em percentual.

OWNER_13 = representa a fração do capital da empresa, que dá direito a voto, possuída pelos três maiores acionistas controladores, expressa em percentual.

OWNER_14 = representa a fração do capital da empresa, que dá direito a voto, possuída pelos quatro maiores acionistas controladores, expressa em percentual.

OWNER_15 = representa a fração do capital da empresa, que dá direito a voto, possuída pelos cinco maiores acionistas controladores, expressa em percentual.

$\mathrm{CA} \_\mathrm{NUM}=$ número de integrantes do conselho de administração.

CA_DIR = percentual de integrantes do conselho de administração que também fazem parte da diretoria executiva.

PERT_AO = percentual do capital da empresa lastreado em ações ordinárias nominativas.

REMUN_A = remuneração anual total dos administradores expressa em milhares de reais.

DEB_ASST = razão entre 0 total de recursos de terceiros e o total de ativos da empresa ao final do exercício anterior.

DIV_PRIC = razão entre os dividendos pagos e o preço da ação mais líquida da empresa na Bolsa de Valores de São Paulo. Os dividendos pagos referem-se ao período anterior ao considerado e o preço da ação é do último dia de negociação do período anterior ao considerado.

DIV_EARN = razão entre os dividendos propostos na DOAR e o lucro líquido do período anterior ao considerado.

LG_TAM = logaritmo do total de ativos ao final do período anterior ao período considerado. 


\subsection{REGRESSÕES COM DADOS EM PAINEL}

Os resultados das regressões com modelo de componentes de erros de uma e duas direções, consideram uma empresa como base em relação a qual os efeitos fixos, peculiares a cada empresa, e os efeitos fixos relativos a passagem do tempo, capturados pelos componentes do erro, são comparados. O programa utilizado para realizar as regressões considera a última empresa do conjunto de observações como a empresa base, no presente estudo a empresa é a Varig. Assim, em se tomando, por exemplo, os resultados da empresa Ambev, terceira empresa na Tabela 5, cujo componente de erro é em duas direções, observa-se que o parâmetro estimado CS3 $($ Cross Section $)=2194993$, estatisticamente significativo ao nível de significância de $1 \%$, capta o efeito fixo, peculiar a essa empresa, de variáveis não inclusas no modelo. A empresa também tem efeitos relativos às variáveis não inclusas no modelo, mas que são comuns a todas as empresas, representados pelo intercepto, ou seja, a empresa base Varig, no valor de 13472763, porém não estatisticamente significativo. O terceiro efeito fixo, capturado pelo terceiro componente do erro, é relativo ao tempo. As estimativas para esses parâmetros aparecem nas tabelas identificadas por TS1, 2, 3 e 4 (primeira coluna) representando, respectivamente, a passagem do tempo (Time Serie) do ano 1997 para 1998, de 1998 para 1999, de 1999 para 2000 e de 2000 para 2001. Pode-se observar que o efeito fixo relativo a passagem de período é estatisticamente significativo, ao nível de 1\%, TS3 = 1092722, na passagem de 1999 para 2000, exatamente no ano da maxidesvalorização do real em janeiro de 1999. Portanto, os efeitos fixos totais, decorrentes de variáveis não incorporadas ao modelo, para a empresa Ambev, foram capturados pelo intercepto (CS da empresa Varig), pelo CS3 = 2194993 e pelos TS1, 2, 3 e 4, respectivamente 728246.8, -493415, 1092722 e 371016.3 .

A técnica utilizada, permitindo que os efeitos de variáveis não integrantes do modelo possam ser capturados, considerando-se a heterogeneidade das empresas e os 
efeitos de correlação serial, ao invés de deixar que tais efeitos fossem capturados apenas pelo intercepto comum a todas as empresas ou mesmo não incluir nem mesmo o intercepto, resulta em estimativas de parâmetros mais confiáveis, como observa Hsiao (2003, p. 3).

As análises das tabelas, constantes dos tópicos 3.1 a 3.5, serão procedidas como no exemplo anterior, identificando empresas que possuem parâmetros estimados que representem peculiaridades das empresas ou da passagem de período, estatisticamente significativos, aos níveis de $1 \%, 5 \%$ e $10 \%$.

Os testes de Durbin_Watson, para verificação de autocorrelação dos resíduos, ao nível de significância de 5\%, indicaram a existência de autocorrelação negativa nas regressões com MVA, P_VPA, RENT_ATI e RENT_PL como variável dependente e autocorrelação positiva com a variável TOBIN'S Q como variável dependente. O problema foi tratado utilizando-se o estimador aproximado de White para a variância assintótica, conforme orienta Wooldridge (2002, p. 57 e 175).

O teste de especificação de Hausman rejeitou, em todas as regressões, o uso de efeitos randômicos. Os resultados são consistentes com nossa expectativa de não ser possível utilizar efeitos randômicos, devido a não se trabalhar com amostra representativa da população. Dessa forma, os resultados das regressões apresentados são de efeitos fixos e, como consequiência, não se pode fazer inferências sobre a população, mas somente sobre o grupo de empresas analisado.

O teste de especificação "F", para efeitos não fixos, rejeitou a hipótese nula, em todas as regressões, indicando que os parâmetros estimados dos componentes de erro e do intercepto não são iguais a zero. Da mesma forma, o teste de especificação "F" rejeitou a hipótese nula, também em todas as regressões, indicando que os parâmetros estimados, conjuntamente, não são iguais a zero.

Além das regressões reportadas neste capítulo, efetuou-se regressões com cada uma das variáveis dependentes, testando-se, separadamente, cada uma das 
hipóteses do estudo (as hipóteses e as respectivas variáveis independentes constam da FIGURA 3). Os resultados encontrados não diferem das regressões, reportadas no estudo, com todas as variáveis de todos os mecanismos de Governança Corporativa.

\subsubsection{Variável dependente MVA - Market Value Added}

\subsubsection{Modelo de efeitos fixos - uma direção}

$\mathrm{Na}$ TABELA 4 são apresentados os resultados da regressão com MVA (Market Value Added) como variável dependente e com modelo de efeitos fixos e uma direção.

As empresas a seguir apresentaram parâmetros estimados do componente de erro secção transversal estatisticamente significante, denotando serem afetadas, de forma particular, por variáveis não incluídas no modelo:

- Ao nível de 1\% - Ambev, Cim Itaú, Eletropaulo Metro, Petrobrás e Vale Rio Doce;

- Ao nível de 5\% - Copel, Cosipa, Duratex, Embratel Part., F Cataguazes, Globo Cabo - Net, Inepar Construcoe, Iochp-Maxion, Ipiranga Pet., Kuala, Magnesita, Telemar Norte Lês, Unipar e Varig;

- Ao nível de 10\% - Bardella, Lojas Americanas, Plascar, Ripasa, Sid Tubarão, Tele Norte Célula, Telemig Celular Part. e Telesp Cel. Part.

Os resultados também mostram que a hipótese referente à política de remuneração da diretoria executiva (H4 na FIGURA 3) não pode ser rejeitada, ao nível de significância de 5\%. Dessa forma, não se pode negar que quando há participação dos administradores nos lucros da empresa, a performance econômica, medida pelo valor de mercado adicionado (variável MVA) é superior a de empresas 
que não oferecem participação nos lucros a seus executivos.

Também se constata nos resultados, que o tamanho da empresa, medido pelo total de seus ativos, pode estar relacionado à performance econômica da empresa medida pelo valor de mercado adicionado.O parâmetro estimado foi estatisticamente significativo ao nível de 5\%. O que surpreende, no entanto, é que essa relação é inversa, isto é, à medida que os ativos são maiores os resultados são menores. O resultado esperado seria uma relação direta, uma vez que a economia de escala proporcionaria melhores resultados em empresas maiores. Possíveis explicações para esse fato poderiam estar embasadas no cenário econômico do período analisado que apresentou taxas de juros médias muito elevadas (25\% a.a. em 1997, com pico de mais de $43 \%$ a.a.; 28,99\% a.a. em 1998, com pico de 36,55\% a.a.; 25,85\% a.a. em 1999, com pico de 32,61\% a.a.; 17,43\% a.a. em 2000, com pico de 19,42\% a.a. e 17,34\% a.a. em 2001, com pico de 20,98\% a.a.) e taxa cambial com forte desvalorização do real, devido à liberação da banda cambial vigente até 1999 (as taxas médias anuais de câmbio no período foram: R\$ 1,08 em 1997, R \$ 1,16 em 1998, R\$ 1,82 em 1999, R\$ 1,83 em 2000 e R $\$ 2,35$ em 2001). Note-se que ou as taxas de juros eram muito altas (anos 1997 a 1999), ou a taxa cambial estava muito alta (1999 a 2001), sendo que em 1999 ambos estavam elevados. Esses fatores podem ter dificultado o desempenho das empresas com maiores ativos, em especial. Outra possível explicação seria a imprecisão da medida de tamanho das empresas, expressa pelo total de ativos. Por fim, poder-se-ia considerar uma possível deseconomia de escala das empresa, isto é, as empresas estariam com ativos superestimados para o nível de atividade da economia e o mercado onde atuam.

$\mathrm{O}$ coeficiente de correlação múltipla resultante, $\mathrm{R}^{2}=95,61 \%$, denota que a especificação do modelo, incluindo o componente de erro de uma direção, culminou em expressiva explicação das variações da performance econômica pelas variáveis independentes modeladas. 
TABELA 4 - RESULTADOS DA REGRESSÃO COM MVA COMO VARIÁVEL DEPENDENTE - MODELO DE EFEITOS FIXOS E UMA DIREÇÃO

\begin{tabular}{|c|c|c|c|c|c|c|}
\hline Variável & $\mathrm{GL}$ & Estimativa & Erro Pad. & Valor $\mathrm{t}$ & $\operatorname{Pr}>|t|$ & Empresa \\
\hline CS1 & 1 & 300898.2 & 1777610 & 0.17 & 0.8658 & Acesita \\
\hline CS2 & 1 & -2005492 & 1724321 & -1.16 & 0.2463 & AES Tiete \\
\hline CS3 & 1 & 15306115 & 2247269 & 6.81 & $<.0001$ & Ambev \\
\hline CS4 & 1 & 430533.4 & 1784050 & 0.24 & 0.8096 & Aracruz \\
\hline CS5 & 1 & -2298619 & 1473019 & -1.56 & 0.1204 & Bahia sul \\
\hline CS6 & 1 & -4278654 & 2369682 & -1.81 & 0.0726 & Bardella \\
\hline CS7 & 1 & -1795465 & 1655384 & -1.08 & 0.2795 & Belgo Mineira \\
\hline CS8 & 1 & -2126803 & 1382949 & -1.54 & 0.1258 & Bombril \\
\hline CS9 & 1 & 3032304 & 2111966 & 1.44 & 0.1528 & Brasil T Par \\
\hline CS10 & 1 & 1706342 & 1676842 & 1.02 & 0.3102 & Brasil Telecom \\
\hline CS11 & 1 & -975923 & 2101991 & -0.46 & 0.6430 & Caemi Metal \\
\hline CS12 & 1 & -1061402 & 1794976 & -0.59 & 0.5550 & Celesc \\
\hline CS13 & 1 & -3032741 & 1848935 & -1.64 & 0.1027 & Cemig \\
\hline CS14 & 1 & -2539702 & 2140653 & -1.19 & 0.2370 & Cesp \\
\hline CS15 & 1 & -7716389 & 2133858 & -3.62 & 0.0004 & Cim Itau \\
\hline CS16 & 1 & -1400472 & 1529593 & -0.92 & 0.3611 & Coelce \\
\hline CS17 & 1 & -2249799 & 1591393 & -1.41 & 0.1592 & Comgas \\
\hline CS18 & 1 & -851262 & 1640442 & -0.52 & 0.6044 & Confab \\
\hline CS19 & 1 & -3615590 & 1791847 & -2.02 & 0.0451 & Copel \\
\hline CS20 & 1 & -794716 & 1845713 & -0.43 & 0.6673 & Copene \\
\hline CS21 & 1 & -3549406 & 1705829 & -2.08 & 0.0389 & Cosipa \\
\hline CS22 & 1 & -1446848 & 1752405 & -0.83 & 0.4101 & Coteminas \\
\hline CS23 & 1 & -3173156 & 2156638 & -1.47 & 0.1429 & CRT Celular \\
\hline CS24 & 1 & -3703965 & 1678162 & -2.21 & 0.0286 & Duratex \\
\hline CS25 & 1 & -2455262 & 2277212 & -1.08 & 0.2824 & Eletrobras \\
\hline CS26 & 1 & $-3,57 \mathrm{E}+10$ & 2934992 & -12.15 & $<.0001$ & Eletropaulo Metro \\
\hline CS27 & 1 & 2030457 & 1819164 & 1.12 & 0.2658 & EMAE \\
\hline CS28 & 1 & 2975655 & 2333799 & 1.28 & 0.2039 & Embraer \\
\hline CS29 & 1 & 4344992 & 2100367 & 2.07 & 0.0400 & Embratel Part \\
\hline CS30 & 1 & -3435159 & 1696043 & -2.03 & 0.0443 & F Cataguazes \\
\hline CS31 & 1 & -2136685 & 1574164 & -1.36 & 0.1764 & Fosfertil \\
\hline CS32 & 1 & -1035869 & 1749084 & -0.59 & 0.5544 & Gerasul - Tracteb \\
\hline CS33 & 1 & -1622257 & 1880594 & -0.86 & 0.3895 & Gerdau Met \\
\hline CS34 & 1 & -1902564 & 1555027 & -1.22 & 0.2227 & Gerdau \\
\hline CS35 & 1 & 3197520 & 1597750 & 2.00 & 0.0469 & Globo Cabo - Net \\
\hline CS36 & 1 & -3396145 & 1662103 & -2.04 & 0.0425 & Inepar Construcoe \\
\hline CS37 & 1 & -4241337 & 1794244 & -2.36 & 0.0191 & Iochp-Maxion \\
\hline CS38 & 1 & -3471503 & 1718510 & -2.02 & 0.0449 & Ipiranga Pet \\
\hline CS39 & 1 & 3554242 & 3145049 & 1.13 & 0.2599 & Itausa \\
\hline CS40 & 1 & -1644647 & 1497665 & -1.10 & 0.2736 & Klabin \\
\hline CS41 & 1 & -5560405 & 2471406 & -2.25 & 0.0257 & Kuala \\
\hline CS42 & 1 & 3492409 & 2252800 & 1.55 & 0.1228 & Light \\
\hline CS43 & 1 & -3651331 & 1946294 & -1.88 & 0.0623 & Lojas Americanas \\
\hline CS44 & 1 & -4646967 & 2054447 & -2.26 & 0.0249 & Magnesita \\
\hline CS45 & 1 & -1390780 & 1657541 & -0.84 & 0.4025 & Petrobras BR \\
\hline CS46 & 1 & 33173570 & 2625871 & 12.63 & $<.0001$ & Petrobras \\
\hline
\end{tabular}




\begin{tabular}{|c|c|c|c|c|c|c|}
\hline Variável & $\mathrm{GL}$ & Estimativa & Erro Pad. & Valor $\mathrm{t}$ & $\operatorname{Pr}>|t|$ & Empresa \\
\hline CS47 & 1 & -3476775 & 1991509 & -1.75 & 0.0825 & Plascar \\
\hline CS48 & 1 & -2307887 & 1386075 & -1.67 & 0.0976 & Ripasa \\
\hline CS49 & 1 & 203623.7 & 2054533 & 0.10 & 0.9212 & Sabesp \\
\hline CS50 & 1 & 1113381 & 2181181 & 0.51 & 0.6104 & Sid Nacional \\
\hline CS51 & 1 & -3758686 & 2069461 & -1.82 & 0.0710 & Sid Tubarao \\
\hline CS52 & 1 & -1840797 & 1715327 & -1.07 & 0.2846 & Suzano \\
\hline CS53 & 1 & -1597325 & 1839590 & -0.87 & 0.3864 & Tele Celular Sul \\
\hline CS54 & 1 & -833046 & 1878591 & -0.44 & 0.6580 & Tele Centroeste C \\
\hline CS55 & 1 & -2604460 & 1855778 & -1.40 & 0.1622 & Tele Leste Celula \\
\hline CS56 & 1 & -1485717 & 1740095 & -0.85 & 0.3943 & Tele Nordeste Cel \\
\hline CS57 & 1 & -4148503 & 2281261 & -1.82 & 0.0706 & Tele Norte Celula \\
\hline CS58 & 1 & 522641.1 & 1743993 & 0.30 & 0.7648 & Tele Sudeste Celu \\
\hline CS59 & 1 & 3597202 & 1683844 & 2.14 & 0.0340 & Telemar Norte Les \\
\hline CS60 & 1 & 4129061 & 2635753 & 1.57 & 0.1190 & Telemar \\
\hline CS61 & 1 & -2160116 & 2296243 & -0.94 & 0.3481 & Telemig Celul Par \\
\hline CS62 & 1 & -2752825 & 1648780 & -1.67 & 0.0967 & Telemig Celular $\mathrm{P}$ \\
\hline CS63 & 1 & -2528625 & 1618046 & -1.56 & 0.1199 & Telepar Celular P \\
\hline$\overline{C S 64}$ & 1 & 3680418 & 2017352 & 1.82 & 0.0697 & Telesp Cel Part P \\
\hline CS65 & 1 & 2716200 & 2481516 & 1.09 & 0.2752 & Telesp Operac \\
\hline CS66 & 1 & -928482 & 2010909 & -0.46 & 0.6448 & Transmissao Pauli \\
\hline CS67 & 1 & -2341217 & 1461902 & -1.60 & 0.1110 & Trikem \\
\hline CS68 & 1 & -1109559 & 2249437 & -0.49 & 0.6224 & Ultrapar \\
\hline CS69 & 1 & -4403239 & 1798855 & -2.45 & 0.0153 & Unipar \\
\hline CS70 & 1 & -1063322 & 1926203 & -0.55 & 0.5816 & Usiminas \\
\hline CS71 & 1 & -270084 & 1303815 & -0.21 & 0.8361 & $\begin{array}{lll}\mathrm{V} & \mathrm{C} & \mathrm{P} \\
\end{array}$ \\
\hline CS72 & 1 & 11306092 & 2183980 & 5.18 & $<.0001$ & Vale Rio Doce \\
\hline Intercept & 1 & 22157225 & 9122418 & 2.43 & 0.0161 & Varig \\
\hline OWNER_1 & 1 & -215.159 & 19106.4 & -0.01 & 0.9910 & OWNER_1 \\
\hline OWNER_15 & 1 & -2345.6 & 22685.9 & -0.10 & 0.9178 & OWNER_15 \\
\hline CA_NUM & 1 & 14934.01 & 31479.4 & 0.47 & 0.6358 & $\mathrm{CA} \quad \mathrm{NUM}$ \\
\hline CA_DIR & 1 & -790.203 & 9067.1 & -0.09 & 0.9306 & CA_DIR \\
\hline D1_CHAIR & 1 & -390078 & 574452 & -0.68 & 0.4980 & D1_CHAIR \\
\hline PERT_AO & 1 & -32679.8 & 20925.4 & -1.56 & 0.1201 & PERT AO \\
\hline D2_LUCRO & 1 & 1253432 & 545852 & 2.30 & 0.0228 & D2_LUCRO \\
\hline REMUN_A & 1 & 493.161 & 827.228 & 0.60 & 0.5518 & REMUN_A \\
\hline DEB_ASST & 1 & -2774.77 & 18180.1 & -0.15 & 0.8789 & DEB_ASST \\
\hline DIV_PRIC & 1 & 8229.81 & 27291.3 & 0.30 & 0.7633 & DIV_PRIC \\
\hline DIV_EARN & 1 & -1061.13 & 2267.4 & -0.47 & 0.6404 & DIV_EARN \\
\hline D3_AUDIT & 1 & 355505.5 & 1227036 & 0.29 & 0.7724 & D3_AUDIT \\
\hline LG_TAM & 1 & -3142473 & 1426161 & -2.20 & 0.0288 & LG_TAM \\
\hline \multicolumn{3}{|c|}{ Método de estimação } & FixOne & \multicolumn{2}{|c|}{$R^{2}$} & 0.9561 \\
\hline \multicolumn{3}{|c|}{ Teste $\mathrm{F}$ para efeitos não fixos } & Valor de F & 46.82 & Prob $>F$ & $<.0001$ \\
\hline \multicolumn{3}{|c|}{ Teste F para todos os coeficientes } & Valor de F & 3286502 & Prob $>\mathrm{F}$ & $<.0001$ \\
\hline \multicolumn{3}{|c|}{ Teste de Hausman $\mathrm{p} /$ efeitos randôm } & Valor de $\mathrm{m}$ & 6.96 & Prob $>m$ & 0.9043 \\
\hline \multicolumn{3}{|c|}{ Durbin-Watson } & 2,62 & & & \\
\hline
\end{tabular}

NOTA:

MVA = Market Value Added.

CS = parâmetro do componente de erro singular a cada empresa - secção transversal.

OWNER_1 = fração do capital da empresa, que dá direito a voto, possuída pelo maior acionista 
controlador, expressa em percentual.

OWNER_15 = representa a fração do capital da empresa, que dá direito a voto, possuída pelos cinco maiores acionistas controladores, expressa em percentual.

$\mathrm{CA} \_\mathrm{NUM}=$ número de integrantes do conselho de administração.

CA_DIR = percentual de integrantes do conselho de administração que também fazem parte da diretoria executiva.

D1_CHAIR = variável dummy utilizada para indicar quando a presidência do conselho de administração e da diretoria executiva são exercidas pela mesma pessoa. A variável assume valor 1 quando a presidência do conselho de administração e a presidência da diretoria executiva são exercidas pela mesma pessoa e 0 quando as duas presidências forem exercidas por pessoas distintas.

PERT_AO = percentual do capital da empresa lastreado em ações ordinárias nominativas.

D2_LUCRO = variável dummy utilizada para indicar quando há participação dos administradores nos lucros da empresa. A variável assume valor 1 quando os administradores têm participação nos lucros auferidos e valor 0 quando não possuem participação nos lucros, isto é, quando a remuneração dos executivos independe dos lucros gerados pela companhia.

REMUN_A = remuneração anual total dos administradores expressa em milhares de reais.

DEB_ASST $=$ razão entre o total de recursos de terceiros e o total de ativos da empresa ao final do exercício anterior.

DIV_PRIC = razão entre os dividendos pagos e o preço da ação mais líquida da empresa na Bolsa de Valores de São Paulo. Os dividendos pagos referem-se ao período anterior ao considerado e o preço da ação é do último dia de negociação do período anterior ao considerado.

DIV_EARN = razão entre os dividendos propostos na DOAR e o lucro líquido do período anterior ao considerado.

D3_AUDIT = variável dummy utilizada para indicar quando a empresa de auditoria externa que presta serviços a companhia for Arthur Andersen, Deloitte Touche Tohmatsu, Ernst \& Young, KPMG, Price Waterhouse ou Coopers \& Lybrand. A variável assume valor 1 quando a companhia foi auditada por uma dessas empresas e 0 quando a empresa de auditoria externa foi outra.

LG_TAM = logaritmo do total de ativos ao final do período anterior ao período considerado.

\subsubsection{Modelo de efeitos fixos - duas direções}

Na TABELA 5 são apresentados os resultados da regressão com MVA (Market Value Added) como variável dependente e com modelo de efeitos fixos e duas direções.

As empresas a seguir apresentaram parâmetros estimados do componente de erro secção transversal estatisticamente significante, denotando serem afetadas, de forma particular, por variáveis não incluídas no modelo:

- Ao nível de 1\% - Ambev, Cim Itaú, Eletropaulo Metro, Petrobrás e Vale Rio Doce;

- Ao nível de 5\% - Cosipa, Embratel Part., Inepar Construções, IochpMaxion, Sid. Tubarão e Telemar Norte Leste; 
- Ao nível de 10\% - Duratex, F. Cataguazes, Globo Cabo - Net, Telesp Cel e Part. e Unipar.

O modelo de componentes de erro em duas direções capta os efeitos do tempo em um dos componentes de erro. Os resultados, neste caso, apresentam o parâmetro estimado do componente de erro relativo ao período entre 1999 e 2000 (TS3) estatisticamente significativo ao nível de $1 \%$. Possivelmente tenha sido devido ao efeito conjunto da queda das taxas médias de juros e da forte desvalorização do real ocorridos nesse período (juros médios passaram de 25,85\%, em 1999, com pico de $32,61 \%$, para $17,43 \%$, com pico de $19,42 \%$, em 2000 ; enquanto a taxa cambial passou de $\mathrm{R} \$ 1,16$ em 1998 para $\mathrm{R} \$ 1,82$ em 1999 e $\mathrm{R} \$ 1,83$ em 2000).

No que concerne às variáveis relativas aos mecanismos de Governança Corporativa, nota-se que os resultados são similares aos da regressão com a mesma variável dependente (MVA) com componentes de erro em uma direção, isto é, a hipótese referente ao mecanismo política de remuneração dos executivos não pode ser rejeitada, ao nível de significância de 5\%, sugerindo que existe relação direta entre programas de remuneração de executivos baseados em resultados e performance econômica medida pelo valor de mercado adicionado.

No entanto, o parâmetro estimado para a variável tamanho da empresa, tamanho medido pelos ativos totais, não se mostrou estatisticamente significante, nem mesmo ao nível de $10 \%$. Pode-se atribuir isso à melhoria da especificação do modelo, refletida, também, no coeficiente de determinação $\mathrm{R}^{2}$ que atingiu $96 \%$. 
TABELA 5 - RESULTADOS DA REGRESSÃO COM MVA COMO VARIÁVEL DEPENDENTE - MODELO DE EFEITOS FIXOS E DUAS DIREÇÕES

\begin{tabular}{|c|c|c|c|c|c|c|}
\hline Variável & $G L$ & Estimativa & Erro Pad. & Valor $\mathrm{t}$ & $\operatorname{Pr}>|t|$ & Empresas \\
\hline CS1 & 1 & 1009259 & 1772962 & 0.57 & 0.5699 & Acesita \\
\hline CS2 & 1 & -2176856 & 1673449 & -1.30 & 0.1950 & AES Tiete \\
\hline CS3 & 1 & 15215981 & 2194993 & 6.93 & $<.0001$ & Ambev \\
\hline CS4 & 1 & -103863 & 1737801 & -0.06 & 0.9524 & Aracruz \\
\hline CS5 & 1 & -2330928 & 1429966 & -1.63 & 0.1049 & Bahia Sul \\
\hline CS6 & 1 & -2607558 & 2463910 & -1.06 & 0.2914 & Bardella \\
\hline CS7 & 1 & -1531607 & 1617425 & -0.95 & 0.3450 & Belgo Mineira \\
\hline CS8 & 1 & -1472139 & 1353715 & -1.09 & 0.2783 & Bombril \\
\hline CS9 & 1 & 2816643 & 2087300 & 1.35 & 0.1789 & Brasil T Par \\
\hline CS10 & 1 & 1569046 & 1655414 & 0.95 & 0.3445 & Brasil Telecom \\
\hline CS11 & 1 & -610653 & 2124240 & -0.29 & 0.7741 & Caemi Metal \\
\hline CS12 & 1 & -1065606 & 1765812 & -0.60 & 0.5470 & Celesc \\
\hline CS13 & 1 & -2980896 & 1803313 & -1.65 & 0.1001 & Cemig \\
\hline CS14 & 1 & -3043381 & 2107516 & -1.44 & 0.1505 & Cesp \\
\hline CS15 & 1 & -7854396 & 2132021 & -3.68 & 0.0003 & Cim Itau \\
\hline CS16 & 1 & -676151 & 1541510 & -0.44 & 0.6615 & Coelce \\
\hline CS17 & 1 & -1588250 & 1576031 & -1.01 & 0.3149 & Comgas \\
\hline CS18 & 1 & -412596 & 1676499 & -0.25 & 0.8059 & Confab \\
\hline CS19 & 1 & -2654496 & 1808197 & -1.47 & 0.1439 & Copel \\
\hline CS20 & 1 & -937147 & 1816063 & -0.52 & 0.6065 & Copene \\
\hline CS21 & 1 & -3629757 & 1661283 & -2.18 & 0.0302 & Cosipa \\
\hline CS22 & 1 & -1251025 & 1697531 & -0.74 & 0.4621 & Coteminas \\
\hline CS23 & 1 & -2682017 & 2124730 & -1.26 & 0.2085 & CRT Celular \\
\hline CS24 & 1 & -3143946 & 1644192 & -1.91 & 0.0575 & Duratex \\
\hline CS25 & 1 & -937655 & 2328584 & -0.40 & 0.6877 & Eletrobras \\
\hline CS26 & 1 & $-3,68 \mathrm{E}+10$ & 2980489 & -12.33 & $<.0001$ & Eletropaulo Metro \\
\hline CS27 & 1 & 2000419 & 1775540 & 1.13 & 0.2614 & EMAE \\
\hline CS28 & 1 & 2223344 & 2283503 & 0.97 & 0.3316 & Embraer \\
\hline CS29 & 1 & 4292552 & 2051102 & 2.09 & 0.0378 & Embratel Part \\
\hline CS30 & 1 & -2940091 & 1671771 & -1.76 & 0.0804 & F Cataguazes \\
\hline CS31 & 1 & -784772 & 1603107 & -0.49 & 0.6251 & Fosfertil \\
\hline CS32 & 1 & -945751 & 1702071 & -0.56 & 0.5792 & Gerasul - Tracteb \\
\hline CS33 & 1 & -1515740 & 1829781 & -0.83 & 0.4086 & Gerdau Met \\
\hline CS34 & 1 & -1757632 & 1510079 & -1.16 & 0.2460 & Gerdau \\
\hline CS35 & 1 & 3058927 & 1578113 & 1.94 & 0.0542 & Globo Cabo - Net \\
\hline CS36 & 1 & -3230696 & 1618341 & -2.00 & 0.0474 & Inepar Construcoe \\
\hline CS37 & 1 & -3587665 & 1790536 & -2.00 & 0.0466 & Iochp-Maxion \\
\hline CS38 & 1 & -2700746 & 1692247 & -1.60 & 0.1123 & Ipiranga Pet \\
\hline CS39 & 1 & 2877338 & 3166393 & 0.91 & 0.3647 & Itausa \\
\hline CS40 & 1 & -1812680 & 1452041 & -1.25 & 0.2135 & Klabin \\
\hline CS41 & 1 & -3952935 & 2648585 & -1.49 & 0.1374 & Kuala \\
\hline CS42 & 1 & 2540940 & 2214852 & 1.15 & 0.2528 & Light \\
\hline CS43 & 1 & -2169665 & 1956815 & -1.11 & 0.2690 & Lojas Americanas \\
\hline CS44 & 1 & -3104840 & 2128445 & -1.46 & 0.1464 & Magnesita \\
\hline CS45 & 1 & -723163 & 1619898 & -0.45 & 0.6558 & PETROBRAS BR \\
\hline CS46 & 1 & 32411229 & 2641288 & 12.27 & $<.0001$ & Petrobras \\
\hline
\end{tabular}




\begin{tabular}{|c|c|c|c|c|c|c|}
\hline Variável & $G L$ & Estimativa & Erro Pad. & Valor $\mathrm{t}$ & $\operatorname{Pr}>|t|$ & Empresas \\
\hline CS47 & 1 & -2232148 & 2099478 & -1.06 & 0.2891 & Plascar \\
\hline CS48 & 1 & -1395657 & 1390294 & -1.00 & 0.3168 & Ripasa \\
\hline CS49 & 1 & -46971 & 2021109 & -0.02 & 0.9815 & Sabesp \\
\hline CS50 & 1 & 911033.1 & 2139484 & 0.43 & 0.6708 & Sid Nacional \\
\hline CS51 & 1 & -4035760 & 2027615 & -1.99 & 0.0481 & Sid Tubarao \\
\hline CS52 & 1 & -1634768 & 1665975 & -0.98 & 0.3278 & Suzano \\
\hline CS53 & 1 & -796700 & 1839796 & -0.43 & 0.6655 & Tele Celular Sul \\
\hline CS54 & 1 & -152044 & 1873223 & -0.08 & 0.9354 & Tele Centroeste C \\
\hline CS55 & 1 & -1490954 & 1906062 & -0.78 & 0.4351 & Tele Leste Celula \\
\hline CS56 & 1 & -696360 & 1762854 & -0.40 & 0.6933 & Tele Nordeste Cel \\
\hline CS57 & 1 & -3451454 & 2311829 & -1.49 & 0.1372 & Tele Norte Celula \\
\hline CS58 & 1 & 674523 & 1715097 & 0.39 & 0.6946 & Tele Sudeste Celu \\
\hline CS59 & 1 & 3703463 & 1652404 & 2.24 & 0.0263 & Telemar Norte Les \\
\hline CS60 & 1 & 3593128 & 2645076 & 1.36 & 0.1761 & Telemar \\
\hline CS61 & 1 & -1995784 & 2287782 & -0.87 & 0.3842 & Telemig Celul Par \\
\hline CS62 & 1 & -2016715 & 1644493 & -1.23 & 0.2217 & Telemig Celular $\mathrm{P}$ \\
\hline CS63 & 1 & -1531966 & 1660630 & -0.92 & 0.3575 & Telepar Celular P \\
\hline CS64 & 1 & 3726763 & 1962196 & 1.90 & 0.0592 & Telesp Cel Part $\mathrm{P}$ \\
\hline CS65 & 1 & 1790241 & 2494612 & 0.72 & 0.4739 & Telesp Operac \\
\hline CS66 & 1 & -707694 & 1975901 & -0.36 & 0.7206 & Transmissao Pauli \\
\hline CS67 & 1 & -1962374 & 1419529 & -1.38 & 0.1686 & Trikem \\
\hline CS68 & 1 & -1514325 & 2220504 & -0.68 & 0.4961 & Ultrapar \\
\hline CS69 & 1 & -3309545 & 1808027 & -1.83 & 0.0689 & Unipar \\
\hline CS70 & 1 & -1352076 & 1901679 & -0.71 & 0.4780 & Usiminas \\
\hline CS71 & 1 & -270795 & 1265832 & -0.21 & 0.8309 & $\mathrm{~V} \quad \mathrm{C} \quad \mathrm{P}$ \\
\hline CS72 & 1 & 10702046 & 2177891 & 4.91 & $<.0001$ & Vale Rio Doce \\
\hline TS1 & 1 & 728246.8 & 464241 & 1.57 & 0.1185 & Série temporal 1 \\
\hline TS2 & 1 & -493415 & 433223 & -1.14 & 0.2563 & Série temporal 2 \\
\hline TS3 & 1 & 1092722 & 415247 & 2.63 & 0.0093 & Série temporal 3 \\
\hline TS4 & 1 & 371016.3 & 330313 & 1.12 & 0.2629 & Série temporal 4 \\
\hline Intercept & 1 & 13472763 & 10215446 & 1.32 & 0.1889 & Varig \\
\hline OWNER_1 & 1 & -8799.61 & 18911,3 & -0.47 & 0.6423 & OWNER_1 \\
\hline OWNER_15 & 1 & 15216.71 & 22324,2 & 0.68 & 0.4964 & OWNER_15 \\
\hline CA_NUM & 1 & 8.742 .992 & 30972,6 & 0.28 & 0.7781 & CA NUM \\
\hline CA_DIR & 1 & -7517.41 & 9087 & -0.83 & 0.4092 & CA_DIR \\
\hline D1_CHAIR & 1 & -141625 & 569728 & -0.25 & 0.8040 & D1_CHAIR \\
\hline PERT_AO & 1 & -28299.3 & 20453,6 & -1.38 & 0.1682 & PERT_AO \\
\hline D2_LUCRO & 1 & 1351041 & 535885 & 2.52 & 0.0126 & D2_LUCRO \\
\hline REMUN_A & 1 & 8.862 .164 & 825.366 & 1.07 & 0.2844 & REMUN_A \\
\hline DEB_ASST & 1 & -1017.44 & 17914,4 & -0.06 & 0.9548 & DEB_ASST \\
\hline DIV_PRIC & 1 & -28496.2 & 30432,7 & -0.94 & 0.3504 & DIV_PRIC \\
\hline DIV_EARN & 1 & -731.62 & 2234,3 & -0.33 & 0.7437 & DIV_EARN \\
\hline D3_AUDIT & 1 & 903270 & 1232248 & 0.73 & 0.4645 & D3_AUDIT \\
\hline LG_TAM & 1 & -2130740 & 1548535 & -1.38 & 0.1706 & LG_TAM \\
\hline \multicolumn{3}{|c|}{ Método de estimação } & FixTwo & \multicolumn{2}{|c|}{$\mathrm{R}^{2}$} & 0.9600 \\
\hline \multicolumn{3}{|c|}{ Teste $\mathrm{F}$ para efeitos não fixos } & Valor de F & 47.83 & Prob $>\mathrm{F}$ & $<.0001$ \\
\hline \multicolumn{3}{|c|}{ Teste de Hausman $\mathrm{p}$ / efeitos randôm. } & Valor de m & 4.75 & Prob > m & 0.9803 \\
\hline \multicolumn{3}{|c|}{ Durbin-Watson } & 2,62 & & & \\
\hline
\end{tabular}

NOTA: 
$\mathrm{CS}$ = parâmetro do componente de erro singular a cada empresa - secção transversal.

TS = parâmetro do componente de erro que capta os efeitos das diferenças intertemporais das secções transversais. TS1, por exemplo, capta as diferenças intertemporais entre os anos 1997 e 1998 . É igual para todas as empresas de uma mesma secção transversal.

OWNER_1 = fração do capital da empresa, que dá direito a voto, possuída pelo maior acionista controlador, expressa em percentual.

OWNER_15 = representa a fração do capital da empresa, que dá direito a voto, possuída pelos cinco maiores acionistas controladores, expressa em percentual.

CA_NUM = número de integrantes do conselho de administração.

CA_DIR = percentual de integrantes do conselho de administração que também fazem parte da diretoria executiva.

D1_CHAIR = variável dummy utilizada para indicar quando a presidência do conselho de administração e da diretoria executiva são exercidas pela mesma pessoa. A variável assume valor 1 quando a presidência do conselho de administração e a presidência da diretoria executiva são exercidas pela mesma pessoa e 0 quando as duas presidências forem exercidas por pessoas distintas.

PERT_AO = percentual do capital da empresa lastreado em ações ordinárias nominativas.

D2_LUCRO = variável dummy utilizada para indicar quando há participação dos administradores nos lucros da empresa. A variável assume valor 1 quando os administradores têm participação nos lucros auferidos e valor 0 quando não possuem participação nos lucros, isto é, quando a remuneração dos executivos independe dos lucros gerados pela companhia.

REMUN_A = remuneração anual total dos administradores expressa em milhares de reais.

DEB_ASST = razão entre o total de recursos de terceiros e o total de ativos da empresa ao final do exercício anterior.

DIV_PRIC = razão entre os dividendos pagos e o preço da ação mais líquida da empresa na Bolsa de Valores de São Paulo. Os dividendos pagos referem-se ao período anterior ao considerado e o preço da ação é do último dia de negociação do período anterior ao considerado.

DIV_EARN = razão entre os dividendos propostos na DOAR e o lucro líquido do período anterior ao considerado.

D3_AUDIT = variável dummy utilizada para indicar quando a empresa de auditoria externa que presta serviços a companhia for Arthur Andersen, Deloitte Touche Tohmatsu, Ernst \& Young, KPMG, Price Waterhouse ou Coopers \& Lybrand. A variável assume valor 1 quando a companhia foi auditada por uma dessas empresas e 0 quando a empresa de auditoria externa foi outra.

LG_TAM = logaritmo do total de ativos ao final do período anterior ao período considerado.

\subsubsection{Variável dependente P_VPA - preço sobre o valor patrimonial das ações.}

\subsubsection{Modelo de efeitos fixos - uma direção}

Os resultados da regressão com modelo de efeitos fixos e uma direção para a

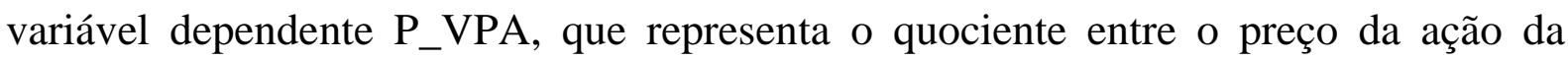
empresa na Bolsa de Valores de São Paulo e o valor patrimonial da ação no último dia do ano, são apresentados na TABELA 6.

As empresas a seguir apresentaram parâmetros estimados do componente de erro secção transversal estatisticamente significante, denotando serem afetadas, de 
forma particular, por variáveis não incluídas no modelo:

- Ao nível de 1\% - Ambev, Eletrobrás, Embraer, Globo Cabo - Net, Light, Ripasa, Trikem e Unipar;

- Ao nível de 5\% - Bardella, Bombril, Copel, Coteminas, Duratex, F Cataguazes, Fosfertil, Gerdau, Iochp-Maxion, Ipiranga Pet., Lojas Americanas, Magnesita, Petrobras BR, Plascar, Suzano, Telepar Celular Part. e Varig;

- Ao nível de 10\% - Bahia Sul, Comgas, Kuala, Sid Nacional, Telemig Celular Part. e Vale Rio Doce.

Os resultados relativos às variáveis representativas dos mecanismos de Governança não permitem rejeitar as hipóteses referentes ao percentual de ações do capital da empresa que dá direito a voto, à concentração de propriedade, representada pelo maior proprietário, à remuneração total da diretoria executiva, à remuneração da diretoria executiva com componente baseado em lucros e ao tamanho da empresa.

O percentual de ações de capital da empresa que dá direito a voto foi estatisticamente significativo ao nível de $1 \%$. O sinal do coeficiente estimado, contudo, é contrário ao sinal esperado. Esperava-se que maiores proporções de ações com direito a voto, como preconizam os códigos de boas práticas de Governança Corporativa, contribuíssem para melhoria da performance econômica das empresas e não que produzissem o efeito contrário. Esse resultado, contudo, é análogo aos achados de Bohren; Odegaard (2001).

A concentração de propriedade, representada pelo maior proprietário, e a remuneração total da diretoria executiva foram estatisticamente significante ao nível de $5 \%$. No que diz respeito à concentração de propriedade, os resultados são aderentes à hipótese formulada de que a concentração de propriedade das empresas está positivamente relacionada com a performance econômica. Quanto à remuneração total da diretoria executiva, porém, esperava-se que a remuneração dos executivos em 
maior monta estivesse associada a melhoria da performance econômica e não que melhores remunerações estivessem associadas a resultados piores, como constatado. Explicações possíveis para esse resultado podem estar na forma de remunerar. Programas de incentivos são difíceis de serem implementados pois é preciso assegurar-se de que as medidas de desempenho utilizadas para incentivar os executivos estejam diretamente relacionadas à performance da empresa no curto e longo prazos e que os executivos não possam manipulá-las. Devido à inexistência de dados publicados mais precisos sobre os programas de remuneração de executivos, devemos considerar os resultados encontrados neste estudo com reserva.

A remuneração da diretoria executiva com componente baseado em lucros e o tamanho da empresa foram estatisticamente significativos ao nível de $10 \%$. O resultado concernente a relação entre a remuneração baseada em programas de participação nos lucros e a performance é condizente com a hipótese formulada. $\mathrm{O}$ tamanho da empresa, no entanto, apresentou resultado oposto à hipótese de que a performance econômica das empresas está relacionada ao tamanho destas, medido pelo total de ativos. No item 3.1.1 foram mencionadas possíveis explicações desse resultado.

O resultado do coeficiente de correlação múltipla de 0,7813 é bastante satisfatório, denota que cerca de $78 \%$ das variações da razão entre os preços das ações das empresas na Bolsa de Valores de São Paulo e seus respectivos valores patrimoniais no último dia do ano são explicados pelas variáveis incluídas no modelo estatístico. Registra-se, no entanto, que esse resultado é inferior aos coeficientes obtidos para a variável dependente MVA (Market Value Aded) de cerca de $96 \%$ para os dois modelos - uma e duas direções -. 
TABELA 6 - RESULTADOS DA REGRESSÃO COM P_VPA COMO VARIÁVEL DEPENDENTE - MODELO DE EFEITOS FIXOS E UMA DIREÇÃO

\begin{tabular}{|c|c|c|c|c|c|c|}
\hline Variável & $G L$ & Estimativa & Erro Pad. & Valor $\mathrm{t}$ & $\operatorname{Pr}>|t|$ & Empresas \\
\hline $\mathrm{CS} 1$ & 1 & -0.64417 & 13.984 & -0.46 & 0.6456 & Acesita \\
\hline $\mathrm{CS} 2$ & 1 & -10.578 & 13.564 & -0.78 & 0.4365 & AES Tiete \\
\hline CS3 & 1 & 460.406 & 17.678 & 2.60 & 0.0100 & Ambev \\
\hline$\overline{C S 4}$ & 1 & 1.448 .151 & 14.034 & 1.03 & 0.3035 & Aracruz \\
\hline CS5 & 1 & -217.365 & 11.588 & -1.88 & 0.0623 & Bahia sul \\
\hline CS6 & 1 & -467.756 & 18.641 & -2.51 & 0.0130 & Bardella \\
\hline CS7 & 1 & -11.857 & 13.022 & -0.91 & 0.3638 & Belgo Mineira \\
\hline CS8 & 1 & -27.823 & 10.879 & -2.56 & 0.0114 & Bombril \\
\hline CS9 & 1 & 1.095 .954 & 16.614 & 0.66 & 0.5103 & Brasil T Par \\
\hline CS10 & 1 & 0.075639 & 13.191 & 0.06 & 0.9543 & Brasil Telecom \\
\hline CS11 & 1 & 0.951698 & 16.535 & 0.58 & 0.5656 & Caemi Metal \\
\hline CS12 & 1 & -0.60659 & 14.120 & -0.43 & 0.6680 & Celesc \\
\hline CS13 & 1 & -196.077 & 14.545 & -1.35 & 0.1793 & Cemig \\
\hline CS14 & 1 & -0.16724 & 16.839 & -0.10 & 0.9210 & Cesp \\
\hline CS15 & 1 & 0.791081 & 16.786 & 0.47 & 0.6380 & Cim Itau \\
\hline CS16 & 1 & -174.438 & 12.033 & -1.45 & 0.1489 & Coelce \\
\hline CS17 & 1 & -222.396 & 12.519 & -1.78 & 0.0773 & Comgas \\
\hline CS18 & 1 & -0.02813 & 12.905 & -0.02 & 0.9826 & Confab \\
\hline CS19 & 1 & -331.686 & 14.096 & -2.35 & 0.0197 & Copel \\
\hline CS20 & 1 & -0.0106 & 14.519 & -0.01 & 0.9942 & Copene \\
\hline CS21 & 1 & -210.534 & 13.419 & -1.57 & 0.1184 & Cosipa \\
\hline CS22 & 1 & -319.175 & 13.785 & -2.32 & 0.0217 & Coteminas \\
\hline CS23 & 1 & -180.277 & 16.965 & -1.06 & 0.2894 & CRT Celular \\
\hline CS24 & 1 & -27.161 & 13.201 & -2.06 & 0.0411 & Duratex \\
\hline CS25 & 1 & -494.207 & 17.914 & -2.76 & 0.0064 & Eletrobras \\
\hline CS26 & 1 & 3.205 .498 & 23.088 & 1.39 & 0.1667 & Eletropaulo Metro \\
\hline CS27 & 1 & 0.003254 & 14.310 & 0.00 & 0.9982 & EMAE \\
\hline CS28 & 1 & 5.429 .048 & 18.359 & 2.96 & 0.0035 & Embraer \\
\hline CS29 & 1 & 0.351747 & 16.523 & 0.21 & 0.8317 & Embratel Part \\
\hline CS30 & 1 & -292.198 & 13.342 & -2.19 & 0.0298 & F Cataguazes \\
\hline CS31 & 1 & -30.174 & 12.383 & -2.44 & 0.0158 & Fosfertil \\
\hline CS32 & 1 & -114.799 & 13.759 & -0.83 & 0.4052 & Gerasul - Tracteb \\
\hline CS33 & 1 & -171.778 & 14.794 & -1.16 & 0.2471 & Gerdau Met \\
\hline CS34 & 1 & -305.934 & 12.233 & -2.50 & 0.0133 & Gerdau \\
\hline CS35 & 1 & 1.620 .917 & 12.569 & 12.90 & $<.0001$ & Globo Cabo - Net \\
\hline CS36 & 1 & -195.825 & 13.075 & -1.50 & 0.1359 & Inepar Construcoe \\
\hline CS37 & 1 & -333.991 & 14.114 & -2.37 & 0.0190 & Iochp-Maxion \\
\hline CS38 & 1 & -295.386 & 13.519 & -2.19 & 0.0302 & Ipiranga Pet \\
\hline CS39 & 1 & 2.930 .693 & 24.741 & 1.18 & 0.2377 & Itausa \\
\hline CS40 & 1 & -117.446 & 11.781 & -1.00 & 0.3202 & Klabin \\
\hline CS41 & 1 & -367.564 & 19.441 & -1.89 & 0.0603 & Kuala \\
\hline CS42 & 1 & 1.323 .761 & 17.722 & 7.47 & $<.0001$ & Light \\
\hline CS43 & 1 & -338.002 & 15.311 & -2.21 & 0.0285 & Lojas Americanas \\
\hline CS44 & 1 & -363.574 & 16.161 & -2.25 & 0.0257 & Magnesita \\
\hline CS45 & 1 & -261.297 & 13.039 & -2.00 & 0.0466 & PETROBRAS BR \\
\hline CS46 & 1 & 2.620 .699 & 20.656 & 1.27 & 0.2062 & Petrobras \\
\hline
\end{tabular}




\begin{tabular}{|c|c|c|c|c|c|c|}
\hline Variável & $G L$ & Estimativa & Erro Pad. & Valor $\mathrm{t}$ & $\operatorname{Pr}>|t|$ & Empresas \\
\hline CS47 & 1 & -407.121 & 15.666 & -2.60 & 0.0101 & Plascar \\
\hline CS48 & 1 & -329.115 & 10.904 & -3.02 & 0.0029 & Ripasa \\
\hline CS49 & 1 & 14.467 & 16.162 & 0.90 & 0.3719 & Sabesp \\
\hline CS50 & 1 & 3.367 .237 & 17.158 & 1.96 & 0.0512 & Sid Nacional \\
\hline CS51 & 1 & -0.46117 & 16.279 & -0.28 & 0.7773 & Sid Tubarao \\
\hline CS52 & 1 & -275.846 & 13.494 & -2.04 & 0.0424 & Suzano \\
\hline CS53 & 1 & -0.7662 & 14.471 & -0.53 & 0.5971 & Tele Celular Sul \\
\hline CS54 & 1 & -0.13669 & 14.778 & -0.09 & 0.9264 & Tele Centroeste $\mathrm{C}$ \\
\hline CS55 & 1 & -215.604 & 14.599 & -1.48 & 0.1414 & Tele Leste Celula \\
\hline CS56 & 1 & -0.31242 & 13.688 & -0.23 & 0.8197 & Tele Nordeste Cel \\
\hline CS57 & 1 & -175.224 & 17.946 & -0.98 & 0.3302 & Tele Norte Celula \\
\hline CS58 & 1 & 0.924675 & 13.719 & 0.67 & 0.5012 & Tele Sudeste Celu \\
\hline CS59 & 1 & -0.74858 & 13.246 & -0.57 & 0.5727 & Telemar Norte Les \\
\hline CS60 & 1 & 2.641 .183 & 20.734 & 1.27 & 0.2044 & Telemar \\
\hline CS61 & 1 & 0.564163 & 18.063 & 0.31 & 0.7552 & Telemig Celul Par \\
\hline CS62 & 1 & -252.905 & 12.970 & -1.95 & 0.0527 & Telemig Celular $\mathrm{P}$ \\
\hline CS63 & 1 & -263.534 & 12.728 & -2.07 & 0.0398 & Telepar Celular P \\
\hline CS64 & 1 & 1.077 .505 & 15.870 & 0.68 & 0.4980 & Telesp Cel Part $\mathrm{P}$ \\
\hline CS65 & 1 & 1.611 .366 & 19.521 & 0.83 & 0.4102 & Telesp Operac \\
\hline CS66 & 1 & -0.75611 & 15.819 & -0.48 & 0.6332 & Transmissao Pauli \\
\hline CS67 & 1 & -326.741 & 11.500 & -2.84 & 0.0050 & Trikem \\
\hline CS68 & 1 & 0.946543 & 17.695 & 0.53 & 0.5934 & Ultrapar \\
\hline CS69 & 1 & -391.201 & 14.151 & -2.76 & 0.0063 & Unipar \\
\hline CS70 & 1 & 0.849074 & 15.153 & 0.56 & 0.5759 & Usiminas \\
\hline CS71 & 1 & -0.86542 & 10.256 & -0.84 & 0.3999 & $\begin{array}{llll}V & C & P \\
\end{array}$ \\
\hline CS72 & 1 & 3.356 .777 & 17.180 & 1.95 & 0.0523 & Vale Rio Doce \\
\hline Intercept & 1 & 1.733 .836 & 71.762 & 2.42 & 0.0167 & Varig \\
\hline OWNER_1 & 1 & 0.036601 & 0.0150 & 2.44 & 0.0159 & OWNER_1 \\
\hline OWNER_15 & 1 & -0.02031 & 0.0178 & -1.14 & 0.2566 & OWNER_15 \\
\hline CA_NUM & 1 & 0.025547 & 0.0248 & 1.03 & 0.3036 & CA N NUM \\
\hline CA_DIR & 1 & 0.000226 & 0.00713 & 0.03 & 0.9748 & CA_DIR \\
\hline D1_CHAIR & 1 & -0.14928 & 0.4519 & -0.33 & 0.7415 & D1_CHAIR \\
\hline PERT_AO & 1 & -0.04409 & 0.0165 & -2.68 & 0.0081 & PERT_AO \\
\hline D2_LUCRO & 1 & 0.794369 & 0.4294 & 1.85 & 0.0659 & D2_LUCRO \\
\hline REMUN_A & 1 & -0.00017 & 0.000065 & -2.57 & 0.0109 & REMUN_A \\
\hline DEB_ASST & 1 & 0.009204 & 0.0143 & 0.64 & 0.5207 & DEB ASST \\
\hline DIV_PRIC & 1 & 0.021808 & 0.0215 & 1.02 & 0.3111 & DIV_PRIC \\
\hline DIV_EARN & 1 & -0.00073 & 0.00178 & -0.41 & 0.6829 & DIV_EARN \\
\hline D3_AUDIT & 1 & -124.547 & 0.9653 & -1.29 & 0.1986 & D3_AUDIT \\
\hline LG_TAM & 1 & -202.832 & 11.219 & -1.81 & 0.0723 & LG_TAM \\
\hline \multicolumn{3}{|c|}{ Método de estimação } & FixOne & \multicolumn{2}{|c|}{$\mathrm{R}^{2}$} & 0.7813 \\
\hline \multicolumn{3}{|c|}{ Teste F para efeitos não fixos } & Valor de F & 8.02 & Prob > F & $<.0001$ \\
\hline \multicolumn{3}{|c|}{ Teste F para todos os coeficientes } & Valor de F & $5,4 \mathrm{E}+11$ & Prob > F & $<.0001$ \\
\hline \multicolumn{3}{|c|}{ Teste de Hausman $\mathrm{p} /$ efeitos randôm. } & Valor de $\mathrm{m}$ & 26.68 & Prob > m & 0.0138 \\
\hline \multicolumn{3}{|c|}{ Durbin-Watson } & 2,69 & & & \\
\hline
\end{tabular}

NOTA:

P_VPA = quociente entre o preço da ação da empresa na Bolsa de Valores de São Paulo e o valor patrimonial no último dia do ano.

$\mathrm{CS}$ = parâmetro do componente de erro singular a cada empresa - secção transversal. 
OWNER_1 = fração do capital da empresa, que dá direito a voto, possuída pelo maior acionista controlador, expressa em percentual.

OWNER_15 = representa a fração do capital da empresa, que dá direito a voto, possuída pelos cinco maiores acionistas controladores, expressa em percentual.

CA $\quad$ NUM = número de integrantes do conselho de administração.

CA_DIR = percentual de integrantes do conselho de administração que também fazem parte da diretoria executiva.

D1_CHAIR = variável dummy utilizada para indicar quando a presidência do conselho de administração e da diretoria executiva são exercidas pela mesma pessoa. A variável assume valor 1 quando a presidência do conselho de administração e a presidência da diretoria executiva são exercidas pela mesma pessoa e 0 quando as duas presidências forem exercidas por pessoas distintas.

PERT_AO = percentual do capital da empresa lastreado em ações ordinárias nominativas.

D2_LUCRO = variável dummy utilizada para indicar quando há participação dos administradores nos lucros da empresa. A variável assume valor 1 quando os administradores têm participação nos lucros auferidos e valor 0 quando não possuem participação nos lucros, isto é, quando a remuneração dos executivos independe dos lucros gerados pela companhia.

REMUN_A = remuneração anual total dos administradores expressa em milhares de reais.

DEB_ASST $=$ razão entre o total de recursos de terceiros e o total de ativos da empresa ao final do exercício anterior.

DIV_PRIC = razão entre os dividendos pagos e o preço da ação mais líquida da empresa na Bolsa de Valores de São Paulo. Os dividendos pagos referem-se ao período anterior ao considerado e o preço da ação é do último dia de negociação do período anterior ao considerado.

DIV_EARN = razão entre os dividendos propostos na DOAR e o lucro líquido do período anterior ao considerado.

D3_AUDIT = variável dummy utilizada para indicar quando a empresa de auditoria externa que presta serviços a companhia for Arthur Andersen, Deloitte Touche Tohmatsu, Ernst \& Young, KPMG, Price Waterhouse ou Coopers \& Lybrand. A variável assume valor 1 quando a companhia foi auditada por uma dessas empresas e 0 quando a empresa de auditoria externa foi outra.

LG_TAM = logaritmo do total de ativos ao final do período anterior ao período considerado.

\subsubsection{Modelo de efeitos fixos - duas direções}

Os resultados da regressão com modelo de efeitos fixos e duas direções para a variável dependente P_VPA, que representa o quociente entre o preço da ação da empresa na Bolsa de Valores de São Paulo e o valor patrimonial da ação no último dia do ano, são apresentados na TABELA 7.

As empresas a seguir apresentaram parâmetros estimados do componente de erro secção transversal estatisticamente significante, denotando serem afetadas, de forma particular, por variáveis não incluídas no modelo:

- Ao nível de 1\% - Embraer, Globo Cabo - Net, Light e Trikem;

- Ao nível de 5\% - Ambev, Bardella, Bombril, Copel, Coteminas, Eletrobrás, F Cataguazes, Gerdau, Iochp-Maxion, Plascar, Ripasa, 


\section{Suzano e Unipar;}

- Ao nível de 10\% - Bahia Sul, Duratex, Fosfertil, Ipiranga Pet, Lojas Americanas, Magnesita, Petrobras BR, Sid Nacional, Telemig Celular Part., Telepar Celular Part., Vale Rio Doce e Varig.

Das variáveis que denotam os mecanismos de Governança Corporativa, quatro apresentaram resultados das estimativas dos parâmetros estatisticamente significante ao nível de 5\%. Essas variáveis representam a concentração de propriedade do maior acionista (OWNER_1), o percentual de ações do capital total da empresa que dá direito a voto (PERT_AO), a existência de remuneração da diretoria executiva baseada em programas de participação nos lucros (D2_LUCRO) e a remuneração total da diretoria executiva (REMUN_A). Os resultados da concentração de propriedade e da existência de programas de remuneração dos executivos baseada em resultados são conforme as hipóteses formuladas, isto é, esperava-se que essas duas variáveis estivessem relacionadas de forma direta com a medida de performance econômica, de forma que quanto maior fosse a concentração de propriedade maior seria a performance; e a existência de programas de remuneração baseada em resultado implicasse, também, a elevação da medida de performance. Sobre as outras duas variáveis, relativas ao percentual de ações do capital total da empresa que dá direito a voto (PERT_AO) e a remuneração total da diretoria executiva (REMUN_A), as hipóteses formuladas preconizaram sinais opostos. Isto é, esperava-se que uma proporção maior do capital constituída de ações com direito a voto estivesse relacionada positivamente com a medida de performance. Da mesma forma, havia expectativa de que a remuneração dos executivos estivesse relacionada de forma direta com a performance. Sobre os resultados adversos aos esperados valem os mesmos comentários formulados no item 3.2.1.

Nesta regressão, à semelhança do que ocorreu com MVA, o modelo de componentes de erro em duas direções captou os efeitos do tempo, peculiares ao 
período entre 1999 e 2000, na variável TS3. O parâmetro estimado foi estatisticamente significativo ao nível de 10\%. Como já mencionado, isso possivelmente tenha ocorrido devido ao efeito conjunto da queda das taxas médias de juros e da forte desvalorização do real ocorridos nesse período (os juros médios passaram de 25,85\% a.a., em 1999, com pico de 32,61\% a.a., para 17,43\% a.a., com pico de 19,42\% a.a., em 2000, enquanto a taxa cambial passou de $\mathrm{R} \$ 1,16$ em 1998 para $\mathrm{R} \$ 1,82$ em 1999 e $\mathrm{R} \$ 1,83$ em 2000).

Também como ocorrido na regressão com MVA como variável dependente componentes de erros em duas direções, o parâmetro estimado para a variável tamanho da empresa, tamanho medido pelos ativos totais, não se mostrou estatisticamente significante, nem mesmo ao nível de 10\%. A explicação pode ser atribuída à ligeira melhoria da especificação do modelo, refletida, também, no coeficiente de correlação múltipla $\mathrm{R}^{2}$, que passou de $78 \%$ com um componente de erro para cerca de $79 \%$ com dois componentes.

TABELA 7 - RESULTADOS DA REGRESSÃO COM P_VPA COMO VARIÁVEL DEPENDENTE - MODELO DE EFEITOS FIXOS E DUAS DIREÇÕES

\begin{tabular}{l|r|r|r|r|r|l}
\hline Variável & GL & Estimativa & Erro Pad. & \multicolumn{1}{l|}{ Valor $t$} & Pr $>|t|$ & Empresas \\
\hline CS1 & 1 & -0.26393 & 14.360 & -0.18 & 0.8544 & Acesita \\
\hline CS2 & 1 & -111.554 & 13.554 & -0.82 & 0.4116 & AES Tiete \\
\hline CS3 & 1 & 4.621 .626 & 17.778 & 2.60 & 0.0101 & Ambev \\
\hline CS4 & 1 & 1.411 .563 & 14.075 & 1.00 & 0.3173 & Aracruz \\
\hline CS5 & 1 & -227.371 & 11.582 & -1.96 & 0.0512 & Bahia Sul \\
\hline CS6 & 1 & -410.623 & 19.956 & -2.06 & 0.0411 & Bardella \\
\hline CS7 & 1 & -106.734 & 13.100 & -0.81 & 0.4163 & Belgo Mineira \\
\hline CS8 & 1 & -240.504 & 10.964 & -2.19 & 0.0296 & Bombril \\
\hline CS9 & 1 & 1.033 .678 & 16.905 & 0.61 & 0.5417 & Brasil T Par \\
\hline CS10 & 1 & 0.077418 & 13.408 & 0.06 & 0.9540 & Brasil Telecom \\
\hline CS11 & 1 & 1.257 .258 & 17.205 & 0.73 & 0.4659 & Caemi Metal \\
\hline CS12 & 1 & -0.47821 & 14.302 & -0.33 & 0.7385 & Celesc \\
\hline CS13 & 1 & -191.634 & 14.605 & -1.31 & 0.1912 & Cemig \\
\hline CS14 & 1 & -0.30232 & 17.069 & -0.18 & 0.8596 & Cesp \\
\hline CS15 & 1 & 0.88324 & 17.268 & 0.51 & 0.6096 & Cim Itau \\
\hline CS16 & 1 & -140.961 & 12.485 & -1.13 & 0.2604 & Coelce \\
\hline CS17 & 1 & -206.557 & 12.765 & -1.62 & 0.1074 & Comgas \\
\hline CS18 & 1 & 0.177619 & 13.578 & 0.13 & 0.8961 & Confab \\
\hline CS19 & 1 & -289.238 & 14.645 & -1.98 & 0.0498 & Copel \\
\hline & & & & & \\
\hline
\end{tabular}




\begin{tabular}{|c|c|c|c|c|c|c|}
\hline Variável & $\mathrm{GL}$ & Estimativa & Erro Pad. & Valor $\mathrm{t}$ & $\operatorname{Pr}>|t|$ & Empresas \\
\hline CS20 & 1 & 0.105831 & 14.709 & 0.07 & 0.9427 & Copene \\
\hline CS21 & 1 & -213.491 & 13.455 & -1.59 & 0.1144 & Cosipa \\
\hline CS22 & 1 & -320.047 & 13.749 & -2.33 & 0.0211 & Coteminas \\
\hline CS23 & 1 & -155.061 & 17.209 & -0.90 & 0.3688 & CRT Celular \\
\hline CS24 & 1 & -249.419 & 13.317 & -1.87 & 0.0627 & Duratex \\
\hline CS25 & 1 & -460.486 & 18.860 & -2.44 & 0.0156 & Eletrobras \\
\hline CS26 & 1 & 2.964 .999 & 24.140 & 1.23 & 0.2210 & Eletropaulo Metro \\
\hline CS27 & 1 & 0.020614 & 14.380 & 0.01 & 0.9886 & EMAE \\
\hline CS28 & 1 & 5.143 .848 & 18.495 & 2.78 & 0.0060 & Embraer \\
\hline CS29 & 1 & 0.348698 & 16.612 & 0.21 & 0.8340 & Embratel Part \\
\hline CS30 & 1 & -277.157 & 13.540 & -2.05 & 0.0421 & F Cataguazes \\
\hline CS31 & 1 & -229.772 & 12.984 & -1.77 & 0.0785 & Fosfertil \\
\hline CS32 & 1 & -120.049 & 13.785 & -0.87 & 0.3850 & Gerasul - Tracteb \\
\hline CS33 & 1 & -145.642 & 14.820 & -0.98 & 0.3271 & Gerdau Met \\
\hline CS34 & 1 & -294.437 & 12.230 & -2.41 & 0.0171 & Gerdau \\
\hline CS35 & 1 & 1.606 .768 & 12.781 & 12.57 & $<.0001$ & Globo Cabo - Net \\
\hline CS36 & 1 & -19.088 & 13.107 & -1.46 & 0.1471 & Inepar Construcoe \\
\hline CS37 & 1 & -310.877 & 14.502 & -2.14 & 0.0334 & Iochp-Maxion \\
\hline CS38 & 1 & -256.991 & 13.706 & -1.88 & 0.0624 & Ipiranga Pet \\
\hline CS39 & 1 & 2.763 .752 & 25.645 & 1.08 & 0.2826 & Itausa \\
\hline CS40 & 1 & -111.778 & 11.760 & -0.95 & 0.3432 & Klabin \\
\hline CS41 & 1 & -308.404 & 21.451 & -1.44 & 0.1523 & Kuala \\
\hline CS42 & 1 & 1.297 .248 & 17.938 & 7.23 & $<.0001$ & Light \\
\hline CS43 & 1 & -286.418 & 15.849 & -1.81 & 0.0724 & Lojas Americanas \\
\hline CS44 & 1 & -292.778 & 17.239 & -1.70 & 0.0912 & Magnesita \\
\hline CS45 & 1 & -234.057 & 13.120 & -1.78 & 0.0761 & PETROBRAS BR \\
\hline CS46 & 1 & 2.259 .188 & 21.392 & 1.06 & 0.2924 & Petrobras \\
\hline CS47 & 1 & -353.455 & 17.004 & -2.08 & 0.0391 & Plascar \\
\hline CS48 & 1 & -284.552 & 11.260 & -2.53 & 0.0124 & Ripasa \\
\hline CS49 & 1 & 1.323 .447 & 16.369 & 0.81 & 0.4199 & Sabesp \\
\hline CS50 & 1 & 3.390 .216 & 17.328 & 1.96 & 0.0520 & Sid Nacional \\
\hline CS51 & 1 & -0.36178 & 16.422 & -0.22 & 0.8259 & Sid Tubarao \\
\hline CS52 & 1 & -2.756 & 13.493 & -2.04 & 0.0426 & Suzano \\
\hline CS53 & 1 & -0.50728 & 14.901 & -0.34 & 0.7339 & Tele Celular Sul \\
\hline CS54 & 1 & 0.182657 & 15.172 & 0.12 & 0.9043 & Tele Centroeste C \\
\hline CS55 & 1 & -172.296 & 15.438 & \begin{tabular}{l|l|}
-1.12 \\
\end{tabular} & 0.2659 & Tele Leste Celula \\
\hline CS56 & 1 & -0.00509 & 14.278 & -0.00 & 0.9972 & Tele Nordeste Cel \\
\hline CS57 & 1 & -154.733 & 18.724 & -0.83 & 0.4097 & Tele Norte Celula \\
\hline CS58 & 1 & 1.025 .017 & 13.891 & 0.74 & 0.4615 & Tele Sudeste Celu \\
\hline CS59 & 1 & -0.6841 & 13.383 & -0.51 & 0.6099 & Telemar Norte Les \\
\hline CS60 & 1 & 2.442 .592 & 21.423 & 1.14 & 0.2558 & Telemar \\
\hline CS61 & 1 & 0.649587 & 18.529 & 0.35 & 0.7263 & Telemig Celul Par \\
\hline CS62 & 1 & -238.588 & 13.319 & -1.79 & 0.0749 & Telemig Celular $\mathrm{P}$ \\
\hline CS63 & 1 & -236.302 & 13.450 & -1.76 & 0.0807 & Telepar Celular $\mathrm{P}$ \\
\hline CS64 & 1 & 1.205 .871 & 15.892 & 0.76 & 0.4490 & Telesp Cel Part $P$ \\
\hline CS65 & 1 & 135.549 & 20.204 & 0.67 & 0.5032 & Telesp Operac \\
\hline CS66 & 1 & -0.56797 & 16.003 & -0.35 & 0.7231 & Transmissao Pauli \\
\hline CS67 & 1 & -309.938 & 11.497 & -2.70 & 0.0077 & Trikem \\
\hline CS68 & 1 & 0.883654 & 17.984 & 0.49 & 0.6238 & Ultrapar \\
\hline CS69 & 1 & -339.282 & 14.644 & -2.32 & 0.0217 & Unipar \\
\hline
\end{tabular}




\begin{tabular}{|c|c|c|c|c|c|c|c|}
\hline Variável & $\mathrm{GL}$ & Estimativa & Erro Pad. & Valor $\mathrm{t}$ & $\operatorname{Pr}>|t|$ & Empresas & \\
\hline CS70 & 1 & 0.96779 & 15.402 & 0.63 & 0.5306 & Usiminas & \\
\hline CS71 & 1 & -0.79913 & 10.252 & -0.78 & 0.4367 & $\mathrm{VCC}$ & \\
\hline CS72 & 1 & 3.258 .719 & 17.639 & 1.85 & 0.0664 & Vale Rio Doce & \\
\hline$\overline{T S 1}$ & 1 & -0.14605 & 0.3760 & -0.39 & 0.6982 & Série Temporal & \\
\hline TS2 & 1 & -0.20256 & 0.3509 & -0.58 & 0.5645 & Série Temporal & 2 \\
\hline TS3 & 1 & 0.571547 & 0.3363 & 1.70 & 0.0910 & Série Temporal & 3 \\
\hline TS4 & 1 & -0.03458 & 0.2675 & -0.13 & 0.8973 & Série Temporal & 4 \\
\hline Intercept & 1 & 1.439 .708 & 82.737 & 1.74 & 0.0836 & Varig & \\
\hline OWNER_1 & 1 & 0.035539 & 0.0153 & 2.32 & 0.0215 & OWNER_1 & \\
\hline OWNER_15 & 1 & -0.01512 & 0.0181 & -0.84 & 0.4041 & OWNER_15 & \\
\hline CA_NUM & 1 & 0.020538 & 0.0251 & 0.82 & 0.4140 & CA NUM & \\
\hline CA_DIR & 1 & -0.00181 & 0.00736 & -0.25 & 0.8064 & CA_DIR & \\
\hline D1_CHAIR & 1. & -0.10896 & 0.4614 & -0.24 & 0.8136 & D1_CHAIR & \\
\hline PERT_AO & 1 & -0.04177 & 0.0166 & -2.52 & 0.0126 & PERT_AO & \\
\hline D2_LUCRO & 1 & 0.937023 & 0.4340 & 2.16 & 0.0322 & D2_LUCRO & \\
\hline REMUN_A & 1 & -0.00015 & 0.000067 & -2.29 & 0.0230 & REMUN_A & \\
\hline DEB_ASST & 1 & 0.010455 & 0.0145 & 0.72 & 0.4721 & DEB_ASST & \\
\hline DIV_PRIC & 1 & -0.00592 & 0.0246 & -0.24 & 0.8104 & DIV PRIC & \\
\hline DIV_EARN & 1 & -0.00032 & 0.00181 & -0.17 & 0.8615 & DIV_EARN & \\
\hline D3_AUDIT & 1 & -131.573 & 0.9980 & -1.32 & 0.1891 & D3_AUDIT & \\
\hline LG_TAM & 1 & -166.005 & 12.542 & -1.32 & 0.1873 & LG_TAM & \\
\hline \multicolumn{3}{|c|}{ Método de estimação } & Fixtwo & \multicolumn{2}{|c|}{$R^{2}$} & & 0.7887 \\
\hline \multicolumn{3}{|c|}{ Teste $F$ para efeitos não fixos } & Valor de $\mathrm{F}$ & 7.77 & Prob $>F$ & & $<.0001$ \\
\hline \multicolumn{3}{|c|}{ Teste de Hausman $\mathrm{p} /$ efeitos randôm. } & Valor de $\mathrm{m}$ & 24.06 & Prob $>m$ & & 0.0306 \\
\hline \multicolumn{3}{|c|}{ Durbin-Watson } & 2,69 & & & & \\
\hline
\end{tabular}

NOTA:

P_VPA = quociente entre o preço da ação da empresa na Bolsa de Valores de São Paulo e o valor patrimonial no último dia do ano.

CS = parâmetro do componente de erro singular a cada empresa - secção transversal.

TS = parâmetro do componente de erro que capta os efeitos das diferenças intertemporais das secções transversais. TS1, por exemplo, capta as diferenças intertemporais entre os anos 1997 e 1998. É igual para todas as empresas de uma mesma secção transversal.

OWNER_1 = fração do capital da empresa, que dá direito a voto, possuída pelo maior acionista controlador, expressa em percentual.

OWNER_15 = representa a fração do capital da empresa, que dá direito a voto, possuída pelos cinco maiores acionistas controladores, expressa em percentual.

CA_NUM = número de integrantes do conselho de administração.

CA_DIR = percentual de integrantes do conselho de administração que também fazem parte da diretoria executiva.

D1_CHAIR = variável dummy utilizada para indicar quando a presidência do conselho de administração e da diretoria executiva são exercidas pela mesma pessoa. A variável assume valor 1 quando a presidência do conselho de administração e a presidência da diretoria executiva são exercidas pela mesma pessoa e 0 quando as duas presidências forem exercidas por pessoas distintas.

PERT_AO = percentual do capital da empresa lastreado em ações ordinárias nominativas.

D2_LUCRO = variável dummy utilizada para indicar quando há participação dos administradores nos lucros da empresa. A variável assume valor 1 quando os administradores têm participação nos lucros auferidos e valor 0 quando não possuem participação nos lucros, isto é, quando a remuneração dos executivos independe dos lucros gerados pela companhia.

REMUN_A = remuneração anual total dos administradores expressa em milhares de reais.

DEB_ASST $=$ razão entre o total de recursos de terceiros e o total de ativos da empresa ao final do exercício anterior. 
DIV_PRIC = razão entre os dividendos pagos e o preço da ação mais líquida da empresa na Bolsa de Valores de São Paulo. Os dividendos pagos referem-se ao período anterior ao considerado e o preço da ação é do último dia de negociação do período anterior ao considerado.

DIV_EARN = razão entre os dividendos propostos na DOAR e o lucro líquido do período anterior ao considerado.

D3_AUDIT = variável dummy utilizada para indicar quando a empresa de auditoria externa que presta serviços a companhia for Arthur Andersen, Deloitte Touche Tohmatsu, Ernst \& Young, KPMG, Price Waterhouse ou Coopers \& Lybrand. A variável assume valor 1 quando a companhia foi auditada por uma dessas empresas e 0 quando a empresa de auditoria externa foi outra.

LG_TAM = logaritmo do total de ativos ao final do período anterior ao período considerado.

\subsubsection{Variável dependente TOBIN'S Q - valor da empresa sobre o valor total dos ativos}

\subsubsection{Modelo de efeitos fixos - uma direção}

Os resultados da regressão com TOBIN'S Q (quociente entre o firm value e o valor dos ativos totais da empresa relativos ao final do ano) como variável dependente e com modelo de efeitos fixos e uma direção são apresentados na TABELA 8.

As empresas a seguir apresentaram parâmetros estimados do componente de erro secção transversal estatisticamente significante, denotando serem afetadas, de forma particular, por variáveis não incluídas no modelo:

- Ao nível de 1\% - Ambev, Aracruz, Bardella, Copel, Eletrobrás, Embraer, Globo Cabo - Net, Light, Lojas Americanas, Magnesita, Petrobras BR, Plascar, Ripasa, Tele Sudeste Cel., Telesp Cel Part., Unipar, Vale Rio Doce e Varig;

- Ao nível de 5\% - Bombril, Caemi Metal, Duratex, Fosfertil, Kuala e Sid Nacional;

- Ao nível de 10\% - Cemig, Confab, Iochp-Maxion, Ipiranga Pet., 
Petrobrás, Sabesp, Tele Nordeste Cel., Telemar, Telesp Operac. e Trikem.

Quanto às variáveis referentes aos mecanismos de Governança Corporativa, os resultados mostraram-se estatisticamente significativos ao nível de 5\% para a concentração de propriedade (OWNER_1), percentual de ações do capital com direito a voto (PERT_AO), remuneração da diretoria executiva (REMUN_A) e tamanho da empresa representado pelo total de ativos (LG_TAM). Os coeficientes estimados dessas variáveis possuem os mesmos sinais apresentados na regressão com P_VPA como variável dependente e efeitos fixos em duas direções (item 3.2.2). Ou seja, a concentração de propriedade está diretamente relacionada à medida de performance, coerente com a hipótese formulada; enquanto o percentual de ações do capital com direito a voto, a remuneração da diretoria executiva e o tamanho da empresa estão inversamente relacionados à medida de performance, contrariando as hipóteses formuladas.

Observa ainda, com relação às variáveis representativas dos mecanismos de Governança, que a variável D2_LUCRO (dummy utilizada para indicar quando há participação dos administradores nos lucros da empresa) que foi estatisticamente significativa ao nível de $10 \%$ na regressão com P_VPA como variável dependente efeitos fixos de duas direções, é substituída, nesta regressão, pela variável do mecanismo de política financeira dividend yield que mostrou-se estatisticamente significativa também ao nível de $10 \%$. Isso sugere que os mecanismos de Governança Corporativa podem ser substitutivos, o que permite um número infinito de combinações e tem como consequiência a provável inexistência de uma estrutura ótima de Governança que seja única. Em outras palavras, a estrutura ótima de Governança, se existe, não é única, pois diversas combinações de mecanismos poderiam produzir uma estrutura ótima.

Por fim, o coeficiente de correlação múltipla resultante, $\mathrm{R}^{2}=80,61 \%$, denota 
que a especificação do modelo, incluindo o componente de erro de uma direção, culminou em expressiva explicação das variações da performance econômica pelas variáveis independentes modeladas.

TABELA 8 - RESULTADOS DA REGRESSÃO COM TOBINS'Q COMO VARIÁVEL DEPENDENTE - MODELO DE EFEITOS FIXOS E UMA DIREÇÃO

\begin{tabular}{|c|c|c|c|c|c|c|}
\hline Variável & $G L$ & Estimativa & Erro Pad. & Valor t & $\operatorname{Pr}>|t|$ & Empresas \\
\hline CS1 & 1 & 0.315828 & 0.2703 & 1.17 & 0.2442 & Acesita \\
\hline CS2 & 1 & -0.01394 & 0.2622 & -0.05 & 0.9577 & AES Tiete \\
\hline CS3 & 1 & 1.752 .221 & 0.3417 & 5.13 & $<.0001$ & Ambev \\
\hline CS4 & 1 & 0.751989 & 0.2713 & 2.77 & 0.0062 & Aracruz \\
\hline CS5 & 1 & -0.11869 & 0.2240 & -0.53 & 0.5968 & Bahia Sul \\
\hline CS6 & 1 & -119.199 & 0.3603 & -3.31 & 0.0011 & Bardella \\
\hline CS7 & 1 & -0.18141 & 0.2517 & -0.72 & 0.4720 & Belgo Mineira \\
\hline CS8 & 1 & -0.46444 & 0.2103 & -2.21 & 0.0285 & Bombril \\
\hline CS9 & 1 & 0.386647 & 0.3211 & 1.20 & 0.2302 & Brasil T Par \\
\hline CS10 & 1 & 0.309146 & 0.2550 & 1.21 & 0.2269 & Brasil Telecom \\
\hline CS11 & 1 & 0.773413 & 0.3196 & 2.42 & 0.0165 & Caemi Metal \\
\hline CS12 & 1 & 0.110892 & 0.2729 & 0.41 & 0.6850 & Celesc \\
\hline CS13 & 1 & -0.46999 & 0.2811 & -1.67 & 0.0963 & Cemig \\
\hline CS14 & 1 & 0.134696 & 0.3255 & 0.41 & 0.6795 & Cesp \\
\hline CS15 & 1 & 0.248442 & 0.3245 & 0.77 & 0.4449 & Cim Itau \\
\hline CS16 & 1 & -0.35321 & 0.2326 & -1.52 & 0.1306 & Coelce \\
\hline CS17 & 1 & -0.38194 & 0.2420 & -1.58 & 0.1162 & Comgas \\
\hline CS18 & 1 & 0.434286 & 0.2494 & 1.74 & 0.0834 & Confab \\
\hline CS19 & 1 & -0.84757 & 0.2725 & -3.11 & 0.0022 & Copel \\
\hline CS20 & 1 & 0.16097 & 0.2807 & 0.57 & 0.5670 & Copene \\
\hline CS21 & 1 & -0.24014 & 0.2594 & -0.93 & 0.3558 & Cosipa \\
\hline CS22 & 1 & -0.22866 & 0.2665 & -0.86 & 0.3920 & Coteminas \\
\hline CS23 & 1 & -0.33368 & 0.3279 & -1.02 & 0.3103 & CRT Celular \\
\hline CS24 & 1 & -0.54474 & 0.2552 & -2.13 & 0.0341 & Duratex \\
\hline CS25 & 1 & -113.463 & 0.3463 & -3.28 & 0.0013 & Eletrobras \\
\hline CS26 & 1 & 0.621019 & 0.4463 & 1.39 & 0.1658 & Eletropaulo Metro \\
\hline CS27 & 1 & 0.145064 & 0.2766 & 0.52 & 0.6006 & EMAE \\
\hline CS28 & 1 & 0.982105 & 0.3549 & 2.77 & 0.0062 & Embraer \\
\hline CS29 & 1 & 0.52662 & 0.3194 & 1.65 & 0.1009 & Embratel Part \\
\hline CS30 & 1 & -0.36689 & 0.2579 & -1.42 & 0.1566 & F Cataguazes \\
\hline CS31 & 1 & -0.49993 & 0.2394 & -2.09 & 0.0381 & Fosfertil \\
\hline CS32 & 1 & 0.105492 & 0.2660 & 0.40 & 0.6921 & Gerasul - Tracteb \\
\hline CS33 & 1 & -0.24994 & 0.2860 & -0.87 & 0.3833 & Gerdau Met \\
\hline CS34 & 1 & -0.35869 & 0.2365 & -1.52 & 0.1310 & Gerdau \\
\hline CS35 & 1 & 2.780 .881 & 0.2430 & 11.45 & $<.0001$ & Globo Cabo - Net \\
\hline CS36 & 1 & -0.36675 & 0.2527 & -1.45 & 0.1485 & Inepar Construcoe \\
\hline CS37 & 1 & -0.53762 & 0.2728 & -1.97 & 0.0503 & Iochp-Maxion \\
\hline CS38 & 1 & -0.48099 & 0.2613 & -1.84 & 0.0673 & Ipiranga Pet \\
\hline CS39 & 1 & 0.122569 & 0.4782 & 0.26 & 0.7980 & Itausa \\
\hline CS40 & 1 & 0.01296 & 0.2277 & 0.06 & 0.9547 & Klabin \\
\hline CS41 & 1 & -0.80426 & 0.3758 & -2.14 & 0.0337 & Kuala \\
\hline
\end{tabular}




\begin{tabular}{|c|c|c|c|c|c|c|}
\hline Variável & GL & Estimativa & Erro Pad. & Valor $\mathrm{t}$ & $|\operatorname{Pr}>| t \mid$ & Empresas \\
\hline CS42 & 1 & 0.963177 & 0.3426 & 2.81 & 0.0055 & Light \\
\hline $\operatorname{cS43}$ & 1 & -0.95411 & 0.2960 & -3.22 & 0.0015 & Lojas Americanas \\
\hline CS44 & 1 & -115.539 & 0.3124 & -3.70 & 0.0003 & Magnesita \\
\hline CS45 & 1 & -0.6581 & 0.2520 & -2.61 & 0.0098 & PETROBRAS BR \\
\hline CS46 & 1 & 0.779896 & 0.3993 & 1.95 & 0.0523 & Petrobras \\
\hline$\overline{C S 47}$ & 1 & -0.82692 & 0.3028 & -2.73 & 0.0069 & Plascar \\
\hline CS48 & 1 & -0.68043 & 0.2108 & -3.23 & 0.0015 & Ripasa \\
\hline CS49 & 1 & 0.553546 & 0.3124 & 1.77 & 0.0781 & Sabesp \\
\hline $\operatorname{cs50}$ & 1 & 0.739844 & 0.3317 & 2.23 & 0.0269 & Sid Nacional \\
\hline CS51 & 1 & -0.02418 & 0.3147 & -0.08 & 0.9388 & Sid Tubarao \\
\hline CS52 & 1 & -0.39073 & 0.2608 & -1.50 & 0.1359 & Suzano \\
\hline CS53 & 1 & 0.403317 & 0.2797 & 1.44 & 0.1511 & Tele Celular sul \\
\hline CS54 & 1 & 0.335473 & 0.2857 & 1.17 & 0.2418 & Tele Centroeste $\mathrm{C}$ \\
\hline CS55 & 1 & -0.11526 & 0.2822 & -0.41 & 0.6834 & Tele Leste Celula \\
\hline CS56 & 1 & 0.452928 & 0.2646 & 1.71 & 0.0887 & Tele Nordeste Cel \\
\hline CS57 & 1 & -0.22017 & 0.3469 & -0.63 & 0.5264 & Tele Norte Celula \\
\hline CS58 & 1 & 0.842809 & 0.2652 & 3.18 & 0.0017 & Tele Sudeste Celu \\
\hline CS59 & 1 & 0.08294 & 0.2560 & 0.32 & 0.7464 & Telemar Norte Les \\
\hline CS60 & 1 & 0.733604 & 0.4008 & 1.83 & 0.0688 & Telemar \\
\hline CS61 & 1 & 0.455861 & 0.3492 & 1.31 & 0.1934 & Telemig Celul Par \\
\hline CS62 & 1 & -0.11044 & 0.2507 & -0.44 & 0.6601 & Telemig Celular P \\
\hline CS63 & 1 & -0.26833 & 0.2460 & -1.09 & 0.2769 & Telepar Celular P \\
\hline CS64 & 1 & 0.81652 & 0.3068 & 2.66 & 0.0085 & Telesp Cel Part P \\
\hline CS65 & 1 & 0.694594 & 0.3773 & 1.84 & 0.0673 & Telesp Operac \\
\hline CS66 & 1 & -0.43778 & 0.3058 & -1.43 & 0.1540 & Transmissao Pauli \\
\hline$\overline{C S 67}$ & 1 & -0.38651 & 0.2223 & -1.74 & 0.0838 & Trikem \\
\hline CS68 & 1 & -0.06749 & 0.3421 & -0.20 & 0.8438 & Ultrapar \\
\hline CS69 & 1 & -0.79573 & 0.2735 & -2.91 & 0.0041 & Unipar \\
\hline CS70 & 1 & 0.242873 & 0.2929 & 0.83 & 0.4081 & Usiminas \\
\hline CS71 & 1 & 0.008442 & 0.1983 & 0.04 & 0.9661 & $\begin{array}{llll}V & C & P \\
\end{array}$ \\
\hline CS72 & 1 & 1.036 .431 & 0.3321 & 3.12 & 0.0021 & Vale Rio Doce \\
\hline Intercept & 1 & 4.428 .775 & 13.872 & 3.19 & 0.0017 & Varig \\
\hline OWNER_1 & 1 & 0.005971 & 0.00291 & 2.06 & 0.0413 & OWNER_1 \\
\hline OWNER_15 & 1 & -0.00434 & 0.00345 & -1.26 & 0.2102 & OWNER_15 \\
\hline CA_NUM & 1 & 0.004229 & 0.00479 & 0.88 & 0.3782 & CA $\quad$ NUM \\
\hline CA_DIR & 1 & 0.001337 & 0.00138 & 0.97 & 0.3335 & CA_DIR \\
\hline D1_CHAIR & 1 & -0.03649 & 0.0874 & -0.42 & 0.6767 & D1_CHAIR \\
\hline PERT_AO & 1 & -0.00696 & 0.00318 & -2.19 & 0.0300 & PERT_AO \\
\hline D2_LUCRO & 1 & 0.096686 & 0.0830 & 1.16 & 0.2456 & D2_LUCRO \\
\hline REMUN_A & 1 & -0.00003 & 0.000013 & -2.14 & 0.0333 & REMUN_A \\
\hline DEB_ASST & 1 & -0.0009 & 0.00276 & -0.33 & 0.7446 & DEB_ASST \\
\hline DIV_PRIC & 1 & 0.007546 & 0.00415 & 1.82 & 0.0707 & DIV_PRIC \\
\hline DIV_EARN & 1 & -0.00025 & 0.000345 & -0.71 & 0.4776 & DIV_EARN \\
\hline D3_AUDIT & 1 & -0.20769 & 0.1866 & -1.11 & 0.2671 & D3_AUDIT \\
\hline LG_TAM & 1 & -0.50091 & 0.2169 & -2.31 & 0.0220 & LG_TAM \\
\hline \multicolumn{3}{|c|}{ Método de estimação } & FixOne & \multicolumn{2}{|c|}{$\mathrm{R}^{2}$} & 0.8061 \\
\hline \multicolumn{3}{|c|}{ Teste $F$ para efeitos não fixos } & Valor de F & 8.76 & Prob > F & $<.0001$ \\
\hline \multicolumn{3}{|c|}{ Teste $\mathrm{F}$ para todos os coeficientes } & Valor de F & $6,3 \mathrm{E}+11$ & Prob > F & $<.0001$ \\
\hline \multicolumn{3}{|c|}{ Teste de Hausman p/ efeitos randôm. } & Valor de $\mathrm{m}$ & 24.65 & Prob $>m$ & 0.0256 \\
\hline \multicolumn{3}{|c|}{ Durbin-Watson } & 1,83 & & & \\
\hline
\end{tabular}


NOTA:

TOBIN'S Q = quociente entre o FV (firm value) e o valor dos ativos totais da empresa relativos ao final do ano.

CS = parâmetro do componente de erro singular a cada empresa - secção transversal.

OWNER_1 = fração do capital da empresa, que dá direito a voto, possuída pelo maior acionista controlador, expressa em percentual.

OWNER_15 = representa a fração do capital da empresa, que dá direito a voto, possuída pelos cinco maiores acionistas controladores, expressa em percentual.

CA_NUM = número de integrantes do conselho de administração.

CA_DIR = percentual de integrantes do conselho de administração que também fazem parte da diretoria executiva.

D1_CHAIR = variável dummy utilizada para indicar quando a presidência do conselho de administração e da diretoria executiva são exercidas pela mesma pessoa. A variável assume valor 1 quando a presidência do conselho de administração e a presidência da diretoria executiva são exercidas pela mesma pessoa e 0 quando as duas presidências forem exercidas por pessoas distintas.

PERT_AO = percentual do capital da empresa lastreado em ações ordinárias nominativas.

D2_LUCRO = variável dummy utilizada para indicar quando há participação dos administradores nos lucros da empresa. A variável assume valor 1 quando os administradores têm participação nos lucros auferidos e valor 0 quando não possuem participação nos lucros, isto é, quando a remuneração dos executivos independe dos lucros gerados pela companhia.

REMUN_A = remuneração anual total dos administradores expressa em milhares de reais.

DEB_ASST = razão entre o total de recursos de terceiros e o total de ativos da empresa ao final do exercício anterior.

DIV_PRIC = razão entre os dividendos pagos e o preço da ação mais líquida da empresa na Bolsa de Valores de São Paulo. Os dividendos pagos referem-se ao período anterior ao considerado e o preço da ação é do último dia de negociação do período anterior ao considerado.

DIV_EARN = razão entre os dividendos propostos na DOAR e o lucro líquido do período anterior ao considerado.

D3_AUDIT = variável dummy utilizada para indicar quando a empresa de auditoria externa que presta serviços a companhia for Arthur Andersen, Deloitte Touche Tohmatsu, Ernst \& Young, KPMG, Price Waterhouse ou Coopers \& Lybrand. A variável assume valor 1 quando a companhia foi auditada por uma dessas empresas e 0 quando a empresa de auditoria externa foi outra.

LG_TAM = logaritmo do total de ativos ao final do período anterior ao período considerado.

\subsubsection{Modelo de efeitos fixos - duas direções}

Os resultados da regressão com TOBIN'S Q (quociente entre o firm value e o valor dos ativos totais da empresa relativos ao final do ano) como variável dependente e com modelo de efeitos fixos e duas direções são apresentados na TABELA 9.

As empresas a seguir apresentaram parâmetros estimados do componente de erro secção transversal estatisticamente significante, denotando serem afetadas, de forma particular, por variáveis não incluídas no modelo: 
- Ao nível de 1\% - Ambev, Aracruz, Caemi Metal, Eletrobrás, Globo Cabo - Net, Magnesita, Tele Sudeste Cel., Telesp Cel Part. e Vale Rio Doce;

- Ao nível de 5\% - Bardella, Confab, Copel, Embraer, Light, Lojas Americanas, Petrobras BR, Ripasa, Sid Nacional, Tele Celular Sul, Tele Nordeste Cel. e Unipar;

- Ao nível de 10\% - Acesita, Cemig, Duratex, Plascar, Tele Centroeste Cel. e Varig.

O parâmetro TS3 mostrou-se novamente estatisticamente significante ao nível de $1 \%$. Sua presença em todas as regressões até aqui analisadas, com efeitos fixos de duas direções, parece confirmar que o período de 1999 a 2000 de fato apresentou características distintas dos demais períodos estudados e as razões prováveis podem estar associadas às variáveis macroeconômicas juro e câmbio conforme exposto nos itens 3.2.1 e 3.2.2.

Quanto aos mecanismos de Governança Corporativa propriamente ditos, a proporção do capital constituída de ações com direito a voto (PERT_AO) foi estatisticamente significativa ao nível de 5\%, enquanto a concentração de propriedade (OWNER_1) e a existência de programa de remuneração da diretoria executiva baseado em lucro (D2_LUCRO) foram estatisticamente significante ao nível de $10 \%$. Todas as variáveis conservam os sinais dos parâmetros estimados iguais aos que apresentaram nas análises anteriores. Ou seja, concentração de propriedade diretamente relacionada à media de performance e proporção do capital constituída de ações com direito a voto e remuneração de executivos baseada em lucros inversamente relacionadas à medida de performance econômica.

O tamanho, medido pelo total de ativos da empresa, parece novamente ter cedido lugar ao componente de erro TS3 quando se compara com a regressão de TOBIN'S Q com um componente de erro, imediatamente anterior. A melhoria na especificação do modelo é, outra vez, a causa provável dessa substituição, dado que o 
coeficiente de correlação múltipla evoluiu de $80,61 \%$ para $83,68 \%$, com melhoria de três pontos percentuais na explicação das variações de TOBIN'S Q pelas variáveis independentes.

TABELA 9 - RESULTADOS DA REGRESSÃO COM TOBINS'Q COMO VARIÁVEL DEPENDENTE - MODELO DE EFEITOS FIXOS E DUAS DIREÇÕES

\begin{tabular}{|c|c|c|c|c|c|c|}
\hline Variável & $\mathrm{GL}$ & Estimativa & Erro Pad. & Valor $\mathrm{t}$ & $\operatorname{Pr}>|t|$ & Empresas \\
\hline CS1 & 1 & 0.510359 & 0.2592 & 1.97 & 0.0505 & Acesita \\
\hline CS2 & 1 & -0.06504 & 0.2446 & -0.27 & 0.7906 & AES Tiete \\
\hline CS3 & 1 & 1.715 .843 & 0.3209 & 5.35 & $<.0001$ & Ambev \\
\hline CS4 & 1 & 0.687185 & 0.2540 & 2.71 & 0.0075 & Aracruz \\
\hline CS5 & 1 & -0.16111 & 0.2090 & -0.77 & 0.4419 & Bahia Sul \\
\hline CS6 & 1 & -0.89545 & 0.3602 & -2.49 & 0.0138 & Bardella \\
\hline CS7 & 1 & -0.15793 & 0.2364 & -0.67 & 0.5050 & Belgo Mineira \\
\hline CS8 & 1 & -0.3101 & 0.1979 & -1.57 & 0.1189 & Bombril \\
\hline CS9 & 1 & 0.295809 & 0.3051 & 0.97 & 0.3336 & Brasil T Par \\
\hline CS10 & 1 & 0.2552 & 0.2420 & 1.05 & 0.2930 & Brasil Telecom \\
\hline CS11 & 1 & 0.903034 & 0.3105 & 2.91 & 0.0041 & Caemi Metal \\
\hline CS12 & 1 & 0.144893 & 0.2581 & 0.56 & 0.5753 & Celesc \\
\hline CS13 & 1 & -0.47168 & 0.2636 & -1.79 & 0.0753 & Cemig \\
\hline CS14 & 1 & 0.014853 & 0.3081 & 0.05 & 0.9616 & Cesp \\
\hline CS15 & 1 & 0.202791 & 0.3116 & 0.65 & 0.5161 & Cim Itau \\
\hline CS16 & 1 & -0.20093 & 0.2253 & -0.89 & 0.3737 & Coelce \\
\hline CS17 & 1 & -0.30075 & 0.2304 & -1.31 & 0.1934 & Comgas \\
\hline CS18 & 1 & 0.544889 & 0.2451 & 2.22 & 0.0274 & Confab \\
\hline CS19 & 1 & -0.63994 & 0.2643 & -2.42 & 0.0165 & Copel \\
\hline CS20 & 1 & 0.14263 & 0.2655 & 0.54 & 0.5917 & Copene \\
\hline CS21 & 1 & -0.28305 & 0.2428 & -1.17 & 0.2453 & Cosipa \\
\hline CS22 & 1 & -0.23387 & 0.2481 & -0.94 & 0.3472 & Coteminas \\
\hline CS23 & 1 & -0.21932 & 0.3106 & -0.71 & 0.4810 & CRT Celular \\
\hline CS24 & 1 & -0.44042 & 0.2403 & -1.83 & 0.0686 & Duratex \\
\hline CS25 & 1 & -0.93852 & 0.3404 & -2.76 & 0.0064 & Eletrobras \\
\hline CS26 & 1 & 0.376608 & 0.4357 & 0.86 & 0.3885 & Eletropaulo Metro \\
\hline CS27 & 1 & 0.113742 & 0.2595 & 0.44 & 0.6617 & EMAE \\
\hline CS28 & 1 & 0.805366 & 0.3338 & 2.41 & 0.0169 & Embraer \\
\hline CS29 & 1 & 0.480912 & 0.2998 & 1.60 & 0.1105 & Embratel Part \\
\hline CS30 & 1 & -0.28157 & 0.2444 & -1.15 & 0.2508 & F Cataguazes \\
\hline CS31 & 1 & -0.18707 & 0.2343 & -0.80 & 0.4258 & Fosfertil \\
\hline CS32 & 1 & 0.071728 & 0.2488 & 0.29 & 0.7735 & Gerasul - Tracteb \\
\hline CS33 & 1 & -0.18074 & 0.2675 & -0.68 & 0.5001 & Gerdau Met \\
\hline CS34 & 1 & -0.33341 & 0.2207 & -1.51 & 0.1327 & Gerdau \\
\hline CS35 & 1 & 2.740 .173 & 0.2307 & 11.88 & $<.0001$ & Globo Cabo - Net \\
\hline CS36 & 1 & -0.35904 & 0.2366 & -1.52 & 0.1309 & Inepar Construcoe \\
\hline CS37 & 1 & -0.40047 & 0.2617 & -1.53 & 0.1278 & Iochp-Maxion \\
\hline CS38 & 1 & -0.32111 & 0.2474 & -1.30 & 0.1959 & Ipiranga Pet \\
\hline CS39 & 1 & -0.07223 & 0.4628 & -0.16 & 0.8762 & Itausa \\
\hline
\end{tabular}




\begin{tabular}{|c|c|c|c|c|c|c|}
\hline Variável & $G L$ & Estimativa & Erro Pad. & Valor $\mathrm{t}$ & $\operatorname{Pr}>|t|$ & Empresas \\
\hline CS40 & 1 & 0.005042 & 0.2123 & 0.02 & 0.9811 & Klabin \\
\hline CS41 & 1 & -0.45176 & 0.3872 & -1.17 & 0.2448 & Kuala \\
\hline CS42 & 1 & 0.777897 & 0.3238 & 2.40 & 0.0173 & Light \\
\hline CS43 & 1 & -0.68839 & 0.2860 & -2.41 & 0.0171 & Lojas Americanas \\
\hline CS44 & 1 & -0.82113 & 0.3111 & -2.64 & 0.0091 & Magnesita \\
\hline CS45 & 1 & -0.55583 & 0.2368 & -2.35 & 0.0200 & PETROBRAS BR \\
\hline CS46 & 1 & 0.543001 & 0.3861 & 1.41 & 0.1614 & Petrobras \\
\hline CS47 & 1 & -0.5127 & 0.3069 & -1.67 & 0.0966 & Plascar \\
\hline CS48 & 1 & -0.47482 & 0.2032 & -2.34 & 0.0206 & Ripasa \\
\hline CS49 & 1 & 0.449 & 0.2954 & 1.52 & 0.1303 & Sabesp \\
\hline CS50 & 1 & 0.684348 & 0.3127 & 2.19 & 0.0300 & Sid Nacional \\
\hline CS51 & 1 & -0.05354 & 0.2964 & -0.18 & 0.8569 & Sid Tubarao \\
\hline CS52 & 1 & -0.39605 & 0.2435 & -1.63 & 0.1057 & Suzano \\
\hline CS53 & 1 & 0.537283 & 0.2689 & 2.00 & 0.0473 & Tele Celular Sul \\
\hline CS54 & 1 & 0.471255 & 0.2738 & 1.72 & 0.0870 & Tele Centroeste C \\
\hline CS55 & 1 & 0.121267 & 0.2786 & 0.44 & 0.6639 & Tele Leste Celula \\
\hline CS56 & 1 & 0.612955 & 0.2577 & 2.38 & 0.0184 & Tele Nordeste Cel \\
\hline CS57 & 1 & -0.09159 & 0.3379 & -0.27 & 0.7867 & Tele Norte Celula \\
\hline CS58 & 1 & 0.872637 & 0.2507 & 3.48 & 0.0006 & Tele Sudeste Celu \\
\hline CS59 & 1 & 0.070667 & 0.2415 & 0.29 & 0.7702 & Telemar Norte Les \\
\hline CS60 & 1 & 0.555123 & 0.3866 & 1.44 & 0.1528 & Telemar \\
\hline CS61 & 1 & 0.491682 & 0.3344 & 1.47 & 0.1433 & Telemig Celul Par \\
\hline CS62 & 1 & -0.0025 & 0.2404 & -0.01 & 0.9917 & Telemig Celular $\mathrm{P}$ \\
\hline CS63 & 1 & -0.08952 & 0.2427 & -0.37 & 0.7127 & Telepar Celular P \\
\hline CS64 & 1 & 0.834559 & 0.2868 & 2.91 & 0.0041 & Telesp Cel Part $\mathrm{P}$ \\
\hline CS65 & 1 & 0.473929 & 0.3646 & 1.30 & 0.1954 & Telesp Operac \\
\hline CS66 & 1 & -0.39667 & 0.2888 & -1.37 & 0.1714 & Transmissao Pauli \\
\hline CS67 & 1 & -0.29939 & 0.2075 & -1.44 & 0.1508 & Trikem \\
\hline CS68 & 1 & -0.11495 & 0.3246 & -0.35 & 0.7236 & Ultrapar \\
\hline CS69 & 1 & -0.55559 & 0.2643 & -2.10 & 0.0369 & Unipar \\
\hline CS70 & 1 & 0.211527 & 0.2780 & 0.76 & 0.4477 & Usiminas \\
\hline CS71 & 1 & 0.011709 & 0.1850 & 0.06 & 0.9496 & $\mathrm{~V} \quad \mathrm{C} \quad \mathrm{P}$ \\
\hline CS72 & 1 & 0.899114 & 0.3184 & 2.82 & 0.0053 & Vale Rio Doce \\
\hline TS1 & 1 & 0.007344 & 0.0679 & 0.11 & 0.9139 & Série Temporal 1 \\
\hline TS2 & 1 & -0.06345 & 0.0633 & -1.00 & 0.3177 & Série Temporal 2 \\
\hline TS3 & 1 & 0.266238 & 0.0607 & 4.39 & $<.0001$ & Série Temporal 3 \\
\hline TS4 & 1 & 0.054224 & 0.0483 & 1.12 & 0.2629 & Série Temporal 4 \\
\hline Intercept & 1 & 2.627 .466 & 14.932 & 1.76 & 0.0802 & Varig \\
\hline OWNER_1 & 1 & 0.005032 & 0.00276 & 1.82 & 0.0704 & OWNER_1 \\
\hline OWNER_15 & 1 & -0.00152 & 0.00326 & -0.47 & 0.6417 & OWNER_15 \\
\hline $\mathrm{CA} \_\mathrm{NUM}$ & 1 & 0.001633 & 0.00453 & 0.36 & 0.7187 & CA_NUM \\
\hline CA_DIR & 1 & 0.000074 & 0.00133 & 0.06 & 0.9557 & CA_DIR \\
\hline D1_CHAIR & 1 & -0.02119 & 0.0833 & -0.25 & 0.7995 & D1_CHAIR \\
\hline PERT_AO & 1 & -0.00601 & 0.00299 & -2.01 & 0.0458 & PERT_AO \\
\hline D2_LUCRO & 1 & 0.151583 & 0.0783 & 1.94 & 0.0546 & D2_LUCRO \\
\hline REMUN_A & 1 & -0.00002 & 0.000012 & -1.53 & 0.1289 & REMUN_A \\
\hline DEB_ASST & 1 & -0.00085 & 0.00262 & -0.32 & 0.7468 & DEB_ASST \\
\hline DIV_PRIC & 1 & -0.00249 & 0.00445 & -0.56 & 0.5766 & DIV_PRIC \\
\hline DIV_EARN & 1 & -0.00014 & 0.000327 & -0.43 & 0.6645 & DIV_EARN \\
\hline D3_AUDIT & 1 & -0.20543 & 0.1801 & -1.14 & 0.2556 & D3_AUDIT \\
\hline
\end{tabular}




\begin{tabular}{|c|c|c|c|c|c|c|}
\hline Variável & $G L$ & Estimativa & Erro Pad. & Valor $\mathrm{t}$ & $\operatorname{Pr}>|t|$ & Empresas \\
\hline LG_TAM & 1 & -0.26725 & 0.2264 & -1.18 & 0.2393 & LG_TAM \\
\hline \multicolumn{3}{|c|}{ Método de estimação } & FixTwo & \multicolumn{2}{|c|}{$\mathrm{R}^{2}$} & 0.8368 \\
\hline \multicolumn{3}{|c|}{ Teste $\mathrm{F}$ para efeitos não fixos } & Valor de F & 10.08 & Prob > F & $<.0001$ \\
\hline \multicolumn{3}{|c|}{ Teste de Hausman $\mathrm{p} /$ efeitos randôm. } & Valor de $\mathrm{m}$ & 24.78 & Prob $>m$ & 0.0247 \\
\hline \multicolumn{3}{|c|}{ Durbin-Watson } & 1,83 & & & \\
\hline
\end{tabular}

NOTA:

TOBIN'S Q = quociente entre o FV (firm value) e o valor dos ativos totais da empresa relativos ao final do ano.

$\mathrm{CS}$ = parâmetro do componente de erro singular a cada empresa - secção transversal.

TS = parâmetro do componente de erro que capta os efeitos das diferenças intertemporais das secções transversais. TS1, por exemplo, capta as diferenças intertemporais entre os anos 1997 e 1998. É igual para todas as empresas de uma mesma secção transversal.

OWNER_1 = fração do capital da empresa, que dá direito a voto, possuída pelo maior acionista controlador, expressa em percentual.

OWNER_15 = representa a fração do capital da empresa, que dá direito a voto, possuída pelos cinco maiores acionistas controladores, expressa em percentual.

$\mathrm{CA} \_\mathrm{NUM}=$ número de integrantes do conselho de administração.

CA_DIR = percentual de integrantes do conselho de administração que também fazem parte da diretoria executiva.

D1_CHAIR = variável dummy utilizada para indicar quando a presidência do conselho de administração e da diretoria executiva são exercidas pela mesma pessoa. A variável assume valor 1 quando a presidência do conselho de administração e a presidência da diretoria executiva são exercidas pela mesma pessoa e 0 quando as duas presidências forem exercidas por pessoas distintas.

PERT_AO = percentual do capital da empresa lastreado em ações ordinárias nominativas.

D2_LUCRO = variável dummy utilizada para indicar quando há participação dos administradores nos lucros da empresa. A variável assume valor 1 quando os administradores têm participação nos lucros auferidos e valor 0 quando não possuem participação nos lucros, isto é, quando a remuneração dos executivos independe dos lucros gerados pela companhia.

REMUN_A = remuneração anual total dos administradores expressa em milhares de reais.

DEB_ASST = razão entre o total de recursos de terceiros e o total de ativos da empresa ao final do exercício anterior.

DIV_PRIC = razão entre os dividendos pagos e o preço da ação mais líquida da empresa na Bolsa de Valores de São Paulo. Os dividendos pagos referem-se ao período anterior ao considerado e o preço da ação é do último dia de negociação do período anterior ao considerado.

DIV_EARN = razão entre os dividendos propostos na DOAR e o lucro líquido do período anterior ao considerado.

D3_AUDIT = variável dummy utilizada para indicar quando a empresa de auditoria externa que presta serviços a companhia for Arthur Andersen, Deloitte Touche Tohmatsu, Ernst \& Young, KPMG, Price Waterhouse ou Coopers \& Lybrand. A variável assume valor 1 quando a companhia foi auditada por uma dessas empresas e 0 quando a empresa de auditoria externa foi outra.

LG_TAM = logaritmo do total de ativos ao final do período anterior ao período considerado. 


\subsubsection{Variável dependente RENT_ATI - rentabilidade do ativo.}

\subsubsection{Modelo de efeitos fixos - uma direção}

Na TABELA 10 são apresentados os resultados da regressão com RENT_ATI como variável dependente e com modelo de efeitos fixos e uma direção.

As empresas a seguir apresentaram parâmetros estimados do componente de erro secção transversal estatisticamente significante, denotando serem afetadas, de forma particular, por variáveis não incluídas no modelo:

- Ao nível de $1 \%$ Ambev, Bombril, Caemi Metal, Coelce, Embraer, Fosfertil, Gerdau Met, Gerdau, Globo Cabo - Net, Petrobrás,Tele Centroeste Cel., Unipar, V C P e Vale Rio Doce;

- Ao nível de 5\% - Acesita, Aracruz, Belgo Mineira, Brasil Telecom, Celesc, Copene, EMAE, Gerasul - Tracteb, Ipiranga Pet, Lojas Americanas, Petrobras BR, Ripasa, Sid Nacional, Suzano, Tele Nordeste Cel, Tele Sudeste Cel. e Usiminas;

- Ao nível de 10\% - Bahia Sul, Brasil T Part., CRT Celular, Embratel Part., Magnesita, Plascar, Sabesp, Tele Celular Sul, Telemig Celul Par., Telesp Operac. e Ultrapar.

Observa, também, que todas as hipóteses formuladas sobre os mecanismos de Governança Corporativa foram rejeitadas, mesmo ao nível de significância de 10\%.

Quanto a porção das variações da variável rentabilidade do ativo explicadas pelas variáveis independentes, obteve-se um coeficiente de correlação múltipla de $69,63 \%$, o menor das regressões até aqui analisadas. 
TABELA 10 - RESULTADOS DA REGRESSÃO COM RENT_ATI COMO VARIÁVEL DEPENDENTE - MODELO DE EFEITOS FIXOS E UMA DIREÇÃO

\begin{tabular}{|c|c|c|c|c|c|c|}
\hline Variável & $G L$ & Estimativa & Erro Pad. & Valor $\mathrm{t}$ & $\operatorname{Pr}>|t|$ & Empresas \\
\hline CS1 & 1 & 125.305 & 53.543 & 2.34 & 0.0204 & Acesita \\
\hline CS2 & 1 & 1.342 .325 & 51.938 & 0.26 & 0.7964 & AES Tiete \\
\hline CS3 & 1 & 1.796 .552 & 67.689 & 2.65 & 0.0087 & Ambev \\
\hline CS4 & 1 & 1.295 .479 & 53.737 & 2.41 & 0.0169 & Aracruz \\
\hline CS5 & 1 & 8.163 .848 & 44.368 & 1.84 & 0.0674 & Bahia Sul \\
\hline CS6 & 1 & 1.077 .216 & 71.377 & 1.51 & 0.1330 & Bardella \\
\hline CS7 & 1 & 1.051 .343 & 49.861 & 2.11 & 0.0364 & Belgo Mineira \\
\hline CS8 & 1 & 1.231 .287 & 41.655 & 2.96 & 0.0035 & Bombril \\
\hline CS9 & 1 & 1.140 .447 & 63.614 & 1.79 & 0.0747 & Brasil T Par \\
\hline CS10 & 1 & 1.057 .776 & 50.508 & 2.09 & 0.0376 & Brasil Telecom \\
\hline CS11 & 1 & 1.651 .239 & 63.314 & 2.61 & 0.0099 & Caemi Metal \\
\hline CS12 & 1 & 1.217 .938 & 54.066 & 2.25 & 0.0255 & Celesc \\
\hline CS13 & 1 & 4.763 .501 & 55.691 & 0.86 & 0.3935 & Cemig \\
\hline CS14 & 1 & 1.009 .718 & 64.478 & 1.57 & 0.1191 & Cesp \\
\hline CS15 & 1 & 9.419 .434 & 64.273 & 1.47 & 0.1445 & Cim Itau \\
\hline CS16 & 1 & 1.782 .481 & 46.072 & 3.87 & 0.0002 & Coelce \\
\hline CS17 & 1 & 722.712 & 47.934 & 1.51 & 0.1334 & Comgas \\
\hline CS18 & 1 & 2.967 .708 & 49.411 & 0.60 & 0.5488 & Confab \\
\hline CS19 & 1 & 8.256 .904 & 53.972 & 1.53 & 0.1278 & Copel \\
\hline CS20 & 1 & 1.180 .645 & 55.594 & 2.12 & 0.0351 & Copene \\
\hline CS21 & 1 & 6.778 .395 & 51.381 & 1.32 & 0.1888 & Cosipa \\
\hline CS22 & 1 & 1.341 .582 & 52.784 & 0.25 & 0.7997 & Coteminas \\
\hline CS23 & 1 & 1.087 .949 & 64.960 & 1.67 & 0.0957 & CRT Celular \\
\hline CS24 & 1 & 6.748 .793 & 50.547 & 1.34 & 0.1835 & Duratex \\
\hline CS25 & 1 & 5.943 .581 & 68.591 & 0.87 & 0.3874 & Eletrobras \\
\hline CS26 & 1 & 1.313 .232 & 88.404 & 1.49 & 0.1392 & Eletropaulo Metro \\
\hline CS27 & 1 & 1.355 .496 & 54.795 & 2.47 & 0.0143 & EMAE \\
\hline CS28 & 1 & 2.632 .388 & 70.296 & 3.74 & 0.0002 & Embraer \\
\hline CS29 & 1 & 1.230 .716 & 63.265 & 1.95 & 0.0533 & Embratel Part \\
\hline CS30 & 1 & 6.069 .523 & 51.086 & 1.19 & 0.2364 & F Cataguazes \\
\hline CS31 & 1 & 1.807 .678 & 47.415 & 3.81 & 0.0002 & Fosfertil \\
\hline CS32 & 1 & 1.113 .198 & 52.684 & 2.11 & 0.0360 & Gerasul - Tracteb \\
\hline CS33 & 1 & 151.274 & 56.645 & 2.67 & 0.0083 & Gerdau Met \\
\hline CS34 & 1 & 1.251 .116 & 46.839 & 2.67 & 0.0082 & Gerdau \\
\hline CS35 & 1 & -249.451 & 48.125 & -5.18 & $<.0001$ & Globo Cabo - Net \\
\hline CS36 & 1 & -29.068 & 50.064 & -0.58 & 0.5622 & Inepar Construcoe \\
\hline CS37 & 1 & -0.17522 & 54.044 & -0.03 & 0.9742 & Iochp-Maxion \\
\hline CS38 & 1 & 1.032 .678 & 51.763 & 2.00 & 0.0475 & Ipiranga Pet \\
\hline CS39 & 1 & 1.356 .042 & 94.731 & 1.43 & 0.1540 & Itausa \\
\hline CS40 & 1 & 5.802 .633 & 45.111 & 1.29 & 0.2000 & Klabin \\
\hline CS41 & 1 & -884.932 & 74.441 & -1.19 & 0.2361 & Kuala \\
\hline CS42 & 1 & 688.731 & 67.856 & 1.01 & 0.3115 & Light \\
\hline CS43 & 1 & 1.265 .216 & 58.624 & 2.16 & 0.0322 & Lojas Americanas \\
\hline CS44 & 1 & 1.182 .619 & 61.881 & 1.91 & 0.0576 & Magnesita \\
\hline CS45 & 1 & 113.424 & 49.926 & 2.27 & 0.0243 & PETROBRAS BR \\
\hline
\end{tabular}




\begin{tabular}{|c|c|c|c|c|c|c|}
\hline Variável & $G L$ & Estimativa & Erro Pad. & Valor $\mathrm{t}$ & $\operatorname{Pr}>|t|$ & Empresas \\
\hline$\overline{C S 46}$ & 1 & 2.177 .091 & 79.093 & 2.75 & 0.0065 & Petrobras \\
\hline CS47 & 1 & -100.902 & 59.986 & -1.68 & 0.0943 & Plascar \\
\hline CS48 & 1 & 9.148 .331 & 41.750 & 2.19 & 0.0297 & Ripasa \\
\hline CS49 & 1 & 1.045 .836 & 61.884 & 1.69 & 0.0928 & Sabesp \\
\hline CS50 & 1 & 1.708 .056 & 65.699 & 2.60 & 0.0101 & Sid Nacional \\
\hline CS51 & 1 & 8.514 .522 & 62.334 & 1.37 & 0.1736 & Sid Tubarao \\
\hline$\overline{C S 52}$ & 1 & 1.341 .181 & 51.667 & 2.60 & 0.0102 & Suzano \\
\hline CS53 & 1 & 9.394 .521 & 55.410 & 1.70 & 0.0917 & Tele Celular Sul \\
\hline CS54 & 1 & 1.553 .357 & 56.585 & 2.75 & 0.0067 & Tele Centroeste $\mathrm{C}$ \\
\hline CS55 & 1 & 1.519 .337 & 55.897 & 0.27 & 0.7861 & Tele Leste Celula \\
\hline CS56 & 1 & 1.059 .083 & 52.413 & 2.02 & 0.0448 & Tele Nordeste Cel \\
\hline CS57 & 1 & 872.597 & 68.713 & 1.27 & 0.2057 & Tele Norte Celula \\
\hline CS58 & 1 & 1.226 .706 & 52.530 & 2.34 & 0.0206 & Tele Sudeste Celu \\
\hline CS59 & 1 & 1.805 .407 & 50.719 & 0.36 & 0.7223 & Telemar Norte Les \\
\hline CS60 & 1 & 842.833 & 79.391 & 1.06 & 0.2898 & Telemar \\
\hline$\overline{C S 61}$ & 1 & 1.220 .696 & 69.165 & 1.76 & 0.0793 & Telemig Celul Par \\
\hline CS62 & 1 & 7.919 .832 & 49.662 & 1.59 & 0.1125 & Telemig Celular $\mathrm{P}$ \\
\hline CS63 & 1 & -354.301 & 48.737 & -0.73 & 0.4682 & Telepar Celular P \\
\hline CS64 & 1 & 127.804 & 60.764 & 0.21 & 0.8336 & Telesp Cel Part P \\
\hline$\overline{C S 65}$ & 1 & 1.451 .267 & 74.745 & 1.94 & 0.0537 & Telesp Operac \\
\hline CS66 & 1 & 8.201 .352 & 60.570 & 1.35 & 0.1774 & Transmissao Pauli \\
\hline CS67 & 1 & 6.095 .031 & 44.034 & 1.38 & 0.1680 & Trikem \\
\hline$\overline{C S 68}$ & 1 & 1.281 .317 & 67.755 & 1.89 & 0.0602 & Ultrapar \\
\hline CS69 & 1 & 1.689 .086 & 54.183 & 3.12 & 0.0021 & Unipar \\
\hline CS70 & 1 & 1.364 .078 & 58.019 & 2.35 & 0.0198 & Usiminas \\
\hline CS71 & 1 & 1.159 .384 & 39.272 & 2.95 & 0.0036 & $\begin{array}{lll}\mathrm{V} & \mathrm{C} & \mathrm{P} \\
\end{array}$ \\
\hline$\overline{C S 72}$ & 1 & 2.166 .372 & 65.783 & 3.29 & 0.0012 & Vale Rio Doce \\
\hline Intercept & 1 & 2.595 .117 & 274.774 & 0.09 & 0.9249 & Varig \\
\hline OWNER_1 & 1 & 0.073696 & 0.0575 & 1.28 & 0.2020 & OWNER_1 \\
\hline OWNER_15 & 1 & 0.014541 & 0.0683 & 0.21 & 0.8317 & OWNER_15 \\
\hline CA_NUM & 1 & -0.10151 & 0.0948 & -1.07 & 0.2858 & CA NUM \\
\hline CA_DIR & 1 & 0.029137 & 0.0273 & 1.07 & 0.2875 & CA_DIR \\
\hline D1_CHAIR & 1 & -101.968 & 17.303 & -0.59 & 0.5564 & D1_CHAIR \\
\hline PERT_AO & 1 & 0.014918 & 0.0630 & 0.24 & 0.8132 & PERT_AO \\
\hline D2_LUCRO & 1 & 2.657 .349 & 16.441 & 1.62 & 0.1078 & D2_LUCRO \\
\hline REMUN_A & 1 & 0.000173 & 0.000249 & 0.69 & 0.4887 & REMUN_A \\
\hline DEB_ASST & 1 & -0.04134 & 0.0548 & -0.75 & 0.4512 & DEB_ASST \\
\hline DIV_PRIC & 1 & -0.13457 & 0.0822 & -1.64 & 0.1034 & DIV_PRIC \\
\hline DIV_EARN & 1 & 0.000105 & 0.00683 & 0.02 & 0.9877 & DIV_EARN \\
\hline D3_AUDIT & 1 & 14.805 & 36.959 & 0.40 & 0.6892 & D3_AUDIT \\
\hline LG_TAM & 1 & -252.085 & 42.957 & -0.59 & 0.5580 & LG_TAM \\
\hline \multicolumn{3}{|c|}{ Método de estimação } & FixOne & \multicolumn{2}{|c|}{$\mathrm{R}^{2}$} & 0.6963 \\
\hline \multicolumn{3}{|c|}{ Teste $F$ para efeitos não fixos } & Valor de $\mathrm{F}$ & 4.56 & Prob > F & $\overline{<.0001}$ \\
\hline \multicolumn{3}{|c|}{ Teste $\mathrm{F}$ para todos os coeficientes } & Valor de F & $3,5 \mathrm{E}+11$ & Prob > F & $<.0001$ \\
\hline \multicolumn{3}{|c|}{ Teste de Hausman p/ efeitos randôm. } & Valor de $\mathrm{m}$ & 17.74 & Prob $>m$ & 0.1678 \\
\hline \multicolumn{3}{|l|}{ Durbin-Watson } & 2,42 & & & \\
\hline
\end{tabular}

NOTA:

RENT_ATI = lucro líquido (LL) do exercício considerado e o ativo total do fim do exercício anterior. CS = parâmetro do componente de erro singular a cada empresa - secção transversal. 
OWNER_1 = fração do capital da empresa, que dá direito a voto, possuída pelo maior acionista controlador, expressa em percentual.

OWNER_15 = representa a fração do capital da empresa, que dá direito a voto, possuída pelos cinco maiores acionistas controladores, expressa em percentual.

CA_NUM = número de integrantes do conselho de administração.

CA_DIR = percentual de integrantes do conselho de administração que também fazem parte da diretoria executiva.

D1_CHAIR = variável dummy utilizada para indicar quando a presidência do conselho de administração e da diretoria executiva são exercidas pela mesma pessoa. A variável assume valor 1 quando a presidência do conselho de administração e a presidência da diretoria executiva são exercidas pela mesma pessoa e 0 quando as duas presidências forem exercidas por pessoas distintas.

PERT_AO = percentual do capital da empresa lastreado em ações ordinárias nominativas.

D2_LUCRO = variável dummy utilizada para indicar quando há participação dos administradores nos lucros da empresa. A variável assume valor 1 quando os administradores têm participação nos lucros auferidos e valor 0 quando não possuem participação nos lucros, isto é, quando a remuneração dos executivos independe dos lucros gerados pela companhia.

REMUN_A = remuneração anual total dos administradores expressa em milhares de reais.

DEB_ASST $=$ razão entre o total de recursos de terceiros e o total de ativos da empresa ao final do exercício anterior.

DIV_PRIC = razão entre os dividendos pagos e o preço da ação mais líquida da empresa na Bolsa de Valores de São Paulo. Os dividendos pagos referem-se ao período anterior ao considerado e o preço da ação é do último dia de negociação do período anterior ao considerado.

DIV_EARN = razão entre os dividendos propostos na DOAR e o lucro líquido do período anterior ao considerado.

D3_AUDIT = variável dummy utilizada para indicar quando a empresa de auditoria externa que presta serviços a companhia for Arthur Andersen, Deloitte Touche Tohmatsu, Ernst \& Young, KPMG, Price Waterhouse ou Coopers \& Lybrand. A variável assume valor 1 quando a companhia foi auditada por uma dessas empresas e 0 quando a empresa de auditoria externa foi outra.

LG_TAM = logaritmo do total de ativos ao final do período anterior ao período considerado.

\subsubsection{Modelo de efeitos fixos - duas direções}

$\mathrm{Na}$ TABELA 11 são apresentados os resultados da regressão com

RENT_ATI como variável dependente e com modelo de efeitos fixos e duas direções.

As empresas a seguir apresentaram parâmetros estimados do componente de erro secção transversal estatisticamente significante, denotando serem afetadas, de forma particular, por variáveis não incluídas no modelo:

- Ao nível de 1\% - Coelce, Embraer, Gerdau, Globo Cabo - Net, Kuala, Petrobrás, Plascar, V C P e Vale Rio Doce;

- Ao nível de 5\% - Ambev, Aracruz, Bombril, Brasil Telecom, Copene, Eletropaulo Metro, EMAE, Fosfertil, Gerdau Met, Sid Nacional, Suzano, Telesp Operac. e Usiminas; 
- Ao nível de 10\% - Belgo Mineira, Brasil T Part, Cesp, Cim Itaú, Embratel Part., Gerasul - Tractebel, Itausa, Petrobras BR, Sabesp, Tele Centroeste Cel., Telepar Celular Part., Unipar e Varig.

Este modelo estatístico com componentes de erro em duas direções mantém a presença do parâmetro estimado TS3, relativo ao período 1999 a 2000, estatisticamente significativo ao nível de $1 \%$ e, diferentemente dos demais, também apresenta o parâmetro estimado TS1, relativo ao período 1997 a 1998, estatisticamente significativo ao nível de 1\%. Nota-se, porém, que o sinal de TS3 que nas regressões foi positivo agora é negativo. Também o sinal do parâmetro estimado de TS1 é negativo. Sob o ponto de vista de fatores macroeconômicos o surgimento de TS1, referente ao período 1997 a 1998 poderia ser explicado pela brusca queda do crescimento do PIB (Produto Interno Bruto) que teve aí seu vale mais expressivo na última década, passando de 3,3\% em 1997 para apenas 0,2\% em 1998.

A presença do parâmetro estimado para o tamanho da empresa, representado pelo total de ativos, estatisticamente significativo ao nível de $10 \%$, juntamente com TS1 e TS3, melhorou o poder explicativo do modelo em relação à regressão da mesma variável dependente (RENT_ATI) conforme pode ser constatado pelo crescimento do coeficiente de correlação múltipla de $69,63 \%$ para $72,80 \%$.

É importante registrar, também, que esta regressão, à semelhança da regressão com efeitos fixos e uma direção da mesma variável dependente, não revelou nenhuma variável dos mecanismos de Governança Corporativa estudados estatisticamente significativos. Ademais, vale notar que também é a primeira regressão com efeitos fixos e duas direções em que o tamanho surge estatisticamente significativo. Por fim, o aparecimento de TS1 pela primeira vez em todas as regressões analisadas e o fato de TS3 ter tido o sinal invertido parece sugerir que a medida de performance rentabilidade do ativo difere de MVA, P_VPA e TOBIN'S Q, cujos resultados foram mais consistentes no que se refere a manter os sinais dos parâmetros 
que foram estatisticamente significativos e a registrar pelo menos uma variável relativa aos mecanismos de Governança estudados estatisticamente significante.

TABELA 11 - RESULTADOS DA REGRESSÃO COM RENT_ATI COMO VARIÁVEL DEPENDENTE - MODELO DE EFEITOS FIXOS E DUAS DIREÇÕES

\begin{tabular}{|c|c|c|c|c|c|c|}
\hline Variável & $\mathrm{GL}$ & Estimativa & Erro Pad. & Valor $\mathrm{t}$ & $\operatorname{Pr}>|t|$ & Empresas \\
\hline CS1 & 1 & 8.282 .036 & 52.946 & 1.56 & 0.1195 & Acesita \\
\hline CS2 & 1 & 1.060 .133 & 49.974 & 0.21 & 0.8322 & AES Tiete \\
\hline CS3 & 1 & 1.532 .157 & 65.549 & 2.34 & 0.0205 & Ambev \\
\hline CS4 & 1 & 1.244 .984 & 51.896 & 2.40 & 0.0175 & Aracruz \\
\hline CS5 & 1 & 7.005 .595 & 42.703 & 1.64 & 0.1027 & Bahia sul \\
\hline CS6 & 1 & -0.72925 & 73.580 & -0.10 & 0.9212 & Bardella \\
\hline CS7 & 1 & 8.460 .188 & 48.301 & 1.75 & 0.0816 & Belgo Mineira \\
\hline CS8 & 1 & 9.513 .249 & 40.426 & 2.35 & 0.0197 & Bombril \\
\hline CS9 & 1 & 1.180 .339 & 62.333 & 1.89 & 0.0599 & Brasil T Par \\
\hline CS10 & 1 & 1.054 .398 & 49.436 & 2.13 & 0.0343 & Brasil Telecom \\
\hline CS11 & 1 & 9.472 .086 & 63.436 & 1.49 & 0.1372 & Caemi Metal \\
\hline CS12 & 1 & 8.477 .464 & 52.732 & 1.61 & 0.1097 & Celesc \\
\hline CS13 & 1 & 2.009 .297 & 53.852 & 0.37 & 0.7095 & Cemig \\
\hline CS14 & 1 & 1.227 .843 & 62.937 & 1.95 & 0.0526 & Cesp \\
\hline CS15 & 1 & 1.097 .899 & 63.669 & 1.72 & 0.0864 & Cim Itau \\
\hline CS16 & 1 & 1.214 .834 & 46.034 & 2.64 & 0.0091 & Coelce \\
\hline CS17 & 1 & 2.769 .671 & 47.065 & 0.59 & 0.5570 & Comgas \\
\hline CS18 & 1 & -305.263 & 50.065 & -0.61 & 0.5428 & Confab \\
\hline CS19 & 1 & 1.804 .304 & 53.998 & 0.33 & 0.7387 & Copel \\
\hline CS20 & 1 & 1.168 .506 & 54.233 & 2.15 & 0.0325 & Copene \\
\hline CS21 & 1 & 5.981 .847 & 49.611 & 1.21 & 0.2295 & Cosipa \\
\hline CS22 & 1 & 0.838902 & 50.693 & 0.17 & 0.8688 & Coteminas \\
\hline CS23 & 1 & 5.695 .735 & 63.451 & 0.90 & 0.3706 & CRT Celular \\
\hline CS24 & 1 & 3.052 .337 & 49.101 & 0.62 & 0.5350 & Duratex \\
\hline CS25 & 1 & -364.849 & 69.539 & -0.52 & 0.6005 & Eletrobras \\
\hline CS26 & 1 & 1.833 .254 & 89.006 & 2.06 & 0.0409 & Eletropaulo Metro \\
\hline CS27 & 1 & 1.338 .042 & 53.023 & 2.52 & 0.0125 & EMAE \\
\hline CS28 & 1 & 2.587 .555 & 68.192 & 3.79 & 0.0002 & Embraer \\
\hline CS29 & 1 & 1.175 .253 & 61.252 & 1.92 & 0.0566 & Embratel Part \\
\hline CS30 & 1 & 2.008 .712 & 49.924 & 0.40 & 0.6879 & F Cataguazes \\
\hline CS31 & 1 & 1.155 .625 & 47.874 & 2.41 & 0.0168 & Fosfertil \\
\hline CS32 & 1 & 9.709 .666 & 50.829 & 1.91 & 0.0577 & Gerasul - Tracteb \\
\hline CS33 & 1 & 1.310 .051 & 54.643 & 2.40 & 0.0175 & Gerdau Met \\
\hline CS34 & 1 & 1.249 .906 & 45.095 & 2.77 & 0.0062 & Gerdau \\
\hline CS35 & 1 & -276.702 & 47.127 & -5.87 & $<.0001$ & Globo Cabo - Net \\
\hline CS36 & 1 & -517.711 & 48.329 & -1.07 & 0.2855 & Inepar Construcoe \\
\hline CS37 & 1 & -505.388 & 53.471 & -0.95 & 0.3459 & Iochp-Maxion \\
\hline CS38 & 1 & 579.809 & 50.536 & 1.15 & 0.2528 & Ipiranga Pet \\
\hline CS39 & 1 & 1.795 .545 & 94.558 & 1.90 & 0.0592 & Itausa \\
\hline CS40 & 1 & 5.640 .016 & 43.362 & 1.30 & 0.1951 & Klabin \\
\hline CS41 & 1 & -208.171 & 79.095 & -2.63 & 0.0092 & Kuala \\
\hline
\end{tabular}




\begin{tabular}{|c|c|c|c|c|c|c|}
\hline Variável & $G \mathrm{GL}$ & Estimativa & Erro Pad. & Valor $\mathrm{t}$ & $\operatorname{Pr}>|t|$ & Empresas \\
\hline CS42 & 1 & 6.208 .585 & 66.142 & 0.94 & 0.3492 & Light \\
\hline CS43 & 1 & 5.786 .371 & 58.436 & 0.99 & 0.3234 & Lojas Americanas \\
\hline CS44 & 1 & 2.104 .683 & 63.562 & 0.33 & 0.7409 & Magnesita \\
\hline$\overline{C S 45}$ & 1 & 8.852 .161 & 48.375 & 1.83 & 0.0689 & $\begin{array}{l}\text { PETROBRAS BR } \\
\end{array}$ \\
\hline CS46 & 1 & 2.633 .415 & 78.877 & 3.34 & 0.0010 & Petrobras \\
\hline CS47 & 1 & -174.844 & 62.697 & -2.79 & 0.0059 & $\begin{array}{l}\text { Plascar } \\
\end{array}$ \\
\hline CS48 & 1 & 4.440 .106 & 41.518 & 1.07 & 0.2863 & Ripasa \\
\hline CS49 & 1 & 1.032 .164 & 60.356 & 1.71 & 0.0890 & Sabesp \\
\hline CS50 & 1 & 1.570 .377 & 63.891 & 2.46 & 0.0149 & Sid Nacional \\
\hline CS51 & 1 & 7.146 .901 & 60.551 & 1.18 & 0.2395 & Sid Tubarao \\
\hline$\overline{C S 52}$ & 1 & 119.938 & 49.751 & 2.41 & 0.0169 & Suzano \\
\hline CS53 & 1 & 3.326 .209 & 54.942 & 0.61 & 0.5457 & Tele Celular Sul \\
\hline CS54 & 1 & 9.439 .159 & 55.940 & 1.69 & 0.0933 & Tele Centroeste C \\
\hline CS55 & 1 & -578.679 & 56.921 & -1.02 & 0.3107 & Tele Leste Celula \\
\hline CS56 & 1 & 4.188 .697 & 52.644 & 0.80 & 0.4273 & Tele Nordeste Cel \\
\hline CS57 & 1 & 0.823615 & 69.038 & 0.12 & 0.9052 & Tele Norte Celula \\
\hline CS58 & 1 & 8.403 .524 & 51.218 & 1.64 & 0.1026 & Tele Sudeste Celu \\
\hline CS59 & 1 & 0.292101 & 49.346 & 0.06 & 0.9529 & Telemar Norte Les \\
\hline CS60 & 1 & 1.156 .486 & 78.990 & 1.46 & 0.1449 & Telemar \\
\hline CS61 & 1 & 5.892 .665 & 68.320 & 0.86 & 0.3896 & Telemig Celul Par \\
\hline CS62 & 1 & 3.345 .381 & 49.109 & 0.68 & 0.4966 & Telemig Celular $\mathrm{P}$ \\
\hline CS63 & 1 & -955.252 & 49.591 & -1.93 & 0.0557 & Telepar Celular P \\
\hline CS64 & 1 & -0.95212 & 58.597 & -0.16 & 0.8711 & Telesp Cel Part P \\
\hline CS65 & 1 & 1.721 .508 & 74.497 & 2.31 & 0.0220 & Telesp Operac \\
\hline CS66 & 1 & 4.140 .558 & 59.006 & 0.70 & 0.4838 & Transmissao Pauli \\
\hline CS67 & 1 & 4.608 .257 & 42.391 & 1.09 & 0.2785 & Trikem \\
\hline CS68 & 1 & 8.689 .961 & 66.311 & 1.31 & 0.1917 & Ultrapar \\
\hline CS69 & 1 & 1.048 .616 & 53.993 & 1.94 & 0.0537 & Unipar \\
\hline CS70 & 1 & 1.381 .163 & 56.790 & 2.43 & 0.0160 & Usiminas \\
\hline CS71 & 1 & 1.083 .287 & 37.802 & 2.87 & 0.0047 & $\mathrm{~V} \quad \mathrm{C} \quad \mathrm{P}$ \\
\hline CS72 & 1 & 2.282 .651 & 65.038 & 3.51 & 0.0006 & Vale Rio Doce \\
\hline TS1 & 1 & -396.935 & 13.864 & -2.86 & 0.0047 & Série Temporal 1 \\
\hline TS2 & 1 & -213.878 & 12.937 & -1.65 & 0.1001 & Série Temporal 2 \\
\hline TS3 & 1 & -450.873 & 12.401 & -3.64 & 0.0004 & Série Temporal 3 \\
\hline TS4 & 1 & 0.017042 & 0.9864 & 0.02 & 0.9862 & Série Temporal 4 \\
\hline Intercept & 1 & 5.503 .293 & 305.064 & 1.80 & 0.0729 & Varig \\
\hline OWNER_1 & 1 & 0.051255 & 0.0565 & 0.91 & 0.3653 & BOWNER_1 \\
\hline OWNER_15 & 1 & -0.0155 & 0.0667 & -0.23 & 0.8164 & OWNER_15 \\
\hline CA_NUM & 1 & -0.081 & 0.0925 & -0.88 & 0.3824 & CA N NUM \\
\hline$\overline{\text { CA_DIR }}$ & 1 & 0.027204 & 0.0271 & 1.00 & 0.3175 & CA_DIR \\
\hline D1_CHAIR & 1 & -207.032 & 17.014 & -1.22 & 0.2253 & D1_CHAIR \\
\hline PERT_AO & 1 & 0.036021 & 0.0611 & 0.59 & 0.5561 & PERT_AO \\
\hline D2_LUCRO & 1 & 2.122 .696 & 16.003 & 1.33 & 0.1864 & D2_LUCRO \\
\hline REMUN_A & 1 & -0.00001 & 0.000246 & -0.06 & 0.9533 & \begin{tabular}{l|l} 
REMUN_A \\
\end{tabular} \\
\hline DEB_ASST & 1 & -0.06783 & 0.0535 & -1.27 & 0.2065 & DEB_ASST \\
\hline DIV_PRIC & 1 & 0.013334 & 0.0909 & 0.15 & 0.8835 & DIV_PRIC \\
\hline DIV_EARN & 1 & -0.00416 & 0.00667 & -0.62 & 0.5336 & DIV_EARN \\
\hline D3_AUDIT & 1 & -168.024 & 36.799 & -0.46 & 0.6485 & D3_AUDIT \\
\hline LG_TAM & 1 & -893.757 & 46.244 & \begin{tabular}{|l|}
-1.93 \\
\end{tabular} & 0.0549 & LG_TAM \\
\hline \multicolumn{3}{|c|}{ Método de estimação } & FixTwo & \multicolumn{2}{|c|}{$R^{2}$} & 0.7280 \\
\hline
\end{tabular}




\begin{tabular}{|c|c|c|c|c|c|c|}
\hline Variável & $\mathrm{GL}$ & Estimativa & Erro Pad. & Valor $\mathrm{t}$ & $\operatorname{Pr}>|t|$ & Empresas \\
\hline \multicolumn{3}{|c|}{ Teste $F$ para efeitos não fixos } & Valor de F & 4.99 & Prob $>$ F & $<.0001$ \\
\hline \multicolumn{3}{|c|}{ Teste de Hausman $\mathrm{p} /$ efeitos randôm. } & Valor de $\mathrm{m}$ & 8.73 & Prob $>m$ & 0.7932 \\
\hline \multicolumn{3}{|c|}{ Durbin-Watson } & 2,42 & & & \\
\hline
\end{tabular}

NOTA:

RENT_ATI = lucro líquido (LL) do exercício considerado e o ativo total do fim do exercício anterior.

$\mathrm{CS}$ = parâmetro do componente de erro singular a cada empresa - secção transversal.

TS = parâmetro do componente de erro que capta os efeitos das diferenças intertemporais das secções transversais. TS1, por exemplo, capta as diferenças intertemporais entre os anos 1997 e 1998. É igual para todas as empresas de uma mesma secção transversal.

OWNER_1 = fração do capital da empresa, que dá direito a voto, possuída pelo maior acionista controlador, expressa em percentual.

OWNER_15 = representa a fração do capital da empresa, que dá direito a voto, possuída pelos cinco maiores acionistas controladores, expressa em percentual.

CA_NUM = número de integrantes do conselho de administração.

CA_DIR = percentual de integrantes do conselho de administração que também fazem parte da diretoria executiva.

D1_CHAIR = variável dummy utilizada para indicar quando a presidência do conselho de administração e da diretoria executiva são exercidas pela mesma pessoa. A variável assume valor 1 quando a presidência do conselho de administração e a presidência da diretoria executiva são exercidas pela mesma pessoa e 0 quando as duas presidências forem exercidas por pessoas distintas.

PERT_AO = percentual do capital da empresa lastreado em ações ordinárias nominativas.

D2_LUCRO = variável dummy utilizada para indicar quando há participação dos administradores nos lucros da empresa. A variável assume valor 1 quando os administradores têm participação nos lucros auferidos e valor 0 quando não possuem participação nos lucros, isto é, quando a remuneração dos executivos independe dos lucros gerados pela companhia.

REMUN_A = remuneração anual total dos administradores expressa em milhares de reais.

DEB_ASST $=$ razão entre o total de recursos de terceiros e o total de ativos da empresa ao final do exercício anterior.

DIV_PRIC = razão entre os dividendos pagos e o preço da ação mais líquida da empresa na Bolsa de Valores de São Paulo. Os dividendos pagos referem-se ao período anterior ao considerado e o preço da ação é do último dia de negociação do período anterior ao considerado.

DIV_EARN = razão entre os dividendos propostos na DOAR e o lucro líquido do período anterior ao considerado.

D3_AUDIT = variável dummy utilizada para indicar quando a empresa de auditoria externa que presta serviços a companhia for Arthur Andersen, Deloitte Touche Tohmatsu, Ernst \& Young, KPMG, Price Waterhouse ou Coopers \& Lybrand. A variável assume valor 1 quando a companhia foi auditada por uma dessas empresas e 0 quando a empresa de auditoria externa foi outra.

LG_TAM = logaritmo do total de ativos ao final do período anterior ao período considerado.

\subsubsection{Variável dependente RENT_PL - rentabilidade do patrimônio líquido.}

\subsubsection{Modelo de efeitos fixos - uma direção}

$\mathrm{Na}$ TABELA 12 são apresentados os resultados da regressão com rentabilidade sobre o patrimônio líquido (RENT_PL) como variável dependente e com 
modelo de efeitos fixos e uma direção.

Os resultados obtidos nesta regressão são sensivelmente diferentes dos resultados das demais regressões analisadas até este ponto do estudo. Em todas as regressões analisadas anteriormente os componentes de erros de uma direção captavam os efeitos de variáveis não incluídas no modelo, e peculiares a cada empresa, de um conjunto de empresas, não de sua maioria, ao nível de significância de $1 \%, 5 \%$ ou $10 \%$. Aqui, os resultados revelam que a quase totalidade das empresas teve o componente de erro CS (secção transversal) estatisticamente significante ao nível de 1\%. As únicas exceções ficaram por conta das empresas Globo Cabo - Net e Varig. Como se verificou nas regressões com rentabilidade do ativo como variável dependente, efeitos fixos de uma e duas direções, também nesta regressão não se registrou nenhuma variável, representativa dos mecanismos de Governança Corporativa, estatisticamente significante, o que implica rejeitar todas as hipóteses formuladas sobre os mecanismos de Governança Corporativa, mesmo ao nível de significância de $10 \%$.

Alie-se aos resultados registrados a obtenção do menor coeficiente de correlação múltipla $(54,18 \%)$ de todas as regressões estudadas e tem-se outra vez indícios de que, da mesma forma que a medida rentabilidade do ativo, as medidas de performance econômica fazem diferença quando se estuda mecanismos de Governança.

TABELA 12 - RESULTADOS DA REGRESSÃO COM RENT_PL COMO VARIÁVEL DEPENDENTE - MODELO DE EFEITOS FIXOS E UMA DIREÇÃO

\begin{tabular}{l|r|r|r|r|r|l}
\hline Variável & GL & \multicolumn{1}{l|}{ Estimativa } & Erro Pad. & \multicolumn{1}{l|}{ Valor $t$} & Pr $>|t|$ & Empresas \\
\hline CS1 & 1 & 207.615 & 405.622 & 5.12 & $<.0001$ & Acesita \\
\hline CS2 & 1 & 1.927 .738 & 393.462 & 4.90 & $<.0001$ & AES Tiete \\
\hline CS3 & 1 & 244.028 & 512.791 & 4.76 & $<.0001$ & Ambev \\
\hline CS4 & 1 & 2.417 .138 & 407.092 & 5.94 & $<.0001$ & Aracruz \\
\hline CS5 & 1 & 2.030 .321 & 336.119 & 6.04 & $<.0001$ & Bahia Sul \\
\hline CS6 & 1 & 1.931 .525 & 540.724 & 3.57 & 0.0005 & Bardella \\
\hline CS7 & 1 & 2.256 .998 & 377.732 & 5.98 & $<.0001$ & Belgo Mineira \\
\hline CS8 & 1 & 222.331 & 315.567 & 7.05 & $<.0001$ & Bombril \\
\hline
\end{tabular}




\begin{tabular}{|c|c|c|c|c|c|c|}
\hline Variável & $\mathrm{GL}$ & Estimativa & Erro Pad. & Valor $\mathrm{t}$ & $\operatorname{Pr}>|t|$ & Empresas \\
\hline CS9 & 1 & 2.675 .412 & 481.917 & 5.55 & $<.0001$ & Brasil T Par \\
\hline CS10 & 1 & 2.493 .773 & 382.628 & 6.52 & $<.0001$ & Brasil Telecom \\
\hline CS11 & 1 & 232.907 & 479.641 & 4.86 & $<.0001$ & Caemi Metal \\
\hline CS12 & 1 & 2.195 .794 & 409.585 & 5.36 & $<.0001$ & Celesc \\
\hline CS13 & 1 & 2.166 .291 & 421.897 & 5.13 & $<.0001$ & Cemig \\
\hline CS14 & 1 & 2.460 .857 & 488.463 & 5.04 & $<.0001$ & Cesp \\
\hline CS15 & 1 & 2.533 .821 & 486.912 & 5.20 & $<.0001$ & Cim Itau \\
\hline CS16 & 1 & 2.400 .327 & 349.029 & 6.88 & $<.0001$ & Coelce \\
\hline CS17 & 1 & 2.202 .593 & 363.130 & 6.07 & $<.0001$ & Comgas \\
\hline CS18 & 1 & 2.176 .096 & 374.323 & 5.81 & $<.0001$ & Confab \\
\hline CS19 & 1 & 2.123 .566 & 408.871 & 5.19 & $<.0001$ & Copel \\
\hline CS20 & 1 & 251.086 & 421.162 & 5.96 & $<.0001$ & Copene \\
\hline CS21 & 1 & 2.216 .296 & 389.243 & 5.69 & $<.0001$ & Cosipa \\
\hline CS22 & 1 & 1.778 .617 & 399.871 & 4.45 & $<.0001$ & Coteminas \\
\hline CS23 & 1 & 2.318 .271 & 492.110 & 4.71 & $<.0001$ & CRT Celular \\
\hline CS24 & 1 & 2.068 .098 & 382.930 & 5.40 & $<.0001$ & Duratex \\
\hline CS25 & 1 & 2.053 .968 & 519.623 & 3.95 & 0.0001 & Eletrobras \\
\hline CS26 & 1 & 2.996 .624 & 669.718 & 4.47 & $<.0001$ & Eletropaulo Metro \\
\hline CS27 & 1 & 2.487 .241 & 415.104 & 5.99 & $<.0001$ & EMAE \\
\hline CS28 & 1 & 3.121 .216 & 532.535 & 5.86 & $<.0001$ & Embraer \\
\hline CS29 & 1 & 2.585 .535 & 479.270 & 5.39 & $<.0001$ & Embratel Part \\
\hline CS30 & 1 & 1.952 .388 & 387.010 & 5.04 & $<.0001$ & F Cataguazes \\
\hline CS31 & 1 & 2.251 .016 & 359.199 & 6.27 & $<.0001$ & Fosfertil \\
\hline CS32 & 1 & 2.343 .847 & 399.113 & 5.87 & $<.0001$ & Gerasul - Tracteb \\
\hline CS33 & 1 & 2.364 .229 & 429.122 & 5.51 & $<.0001$ & Gerdau Met \\
\hline CS34 & 1 & 2.116 .786 & 354.832 & 5.97 & $<.0001$ & Gerdau \\
\hline CS35 & 1 & 2.336 .928 & 364.581 & 0.64 & 0.5223 & Globo Cabo - Net \\
\hline CS36 & 1 & 1.848 .199 & 379.265 & 4.87 & $<.0001$ & Inepar Construcoe \\
\hline CS37 & 1 & 1.667 .437 & 409.418 & 4.07 & $<.0001$ & Iochp-Maxion \\
\hline CS38 & 1 & 2.125 .149 & 392.137 & 5.42 & $<.0001$ & Ipiranga Pet \\
\hline CS39 & 1 & 3.176 .621 & 717.650 & 4.43 & $<.0001$ & Itausa \\
\hline CS40 & 1 & 2.080 .927 & 341.743 & 6.09 & $<.0001$ & Klabin \\
\hline CS41 & 1 & 1.560 .344 & 563.935 & 2.77 & 0.0062 & Kuala \\
\hline CS42 & 1 & 246.278 & 514.053 & 4.79 & $<.0001$ & Light \\
\hline CS43 & 1 & 2.207 .903 & 444.113 & 4.97 & $<.0001$ & Lojas Americanas \\
\hline CS44 & 1 & 2.140 .545 & 468.792 & 4.57 & $<.0001$ & Magnesita \\
\hline CS45 & 1 & 2.319 .429 & 378.224 & 6.13 & $<.0001$ & PETROBRAS BR \\
\hline CS46 & 1 & 2.863 .752 & 599.182 & 4.78 & $<.0001$ & Petrobras \\
\hline CS47 & 1 & 1.692 .605 & 454.430 & 3.72 & 0.0003 & \begin{tabular}{|l|l|} 
Plascar \\
\end{tabular} \\
\hline CS48 & 1 & 2.121 .942 & 316.280 & 6.71 & $<.0001$ & Ripasa \\
\hline CS49 & 1 & 259.003 & 468.812 & 5.52 & $<.0001$ & Sabesp \\
\hline CS50 & 1 & 2.882 .908 & 497.710 & 5.79 & $<.0001$ & Sid Nacional \\
\hline CS51 & 1 & 2.301 .475 & 472.218 & 4.87 & $<.0001$ & Sid Tubarao \\
\hline CS52 & 1 & 2.080 .702 & 391.410 & 5.32 & $<.0001$ & Suzano \\
\hline CS53 & 1 & 2.236 .462 & 419.765 & 5.33 & $<.0001$ & Tele Celular Sul \\
\hline CS54 & 1 & 2.349 .949 & 428.664 & 5.48 & $<.0001$ & Tele Centroeste C \\
\hline CS55 & 1 & 1.896 .322 & 423.459 & 4.48 & $<.0001$ & Tele Leste Celula \\
\hline CS56 & 1 & 2.186 .593 & 397.062 & 5.51 & $<.0001$ & Tele Nordeste Cel \\
\hline CS57 & 1 & 2.076 .495 & 520.547 & 3.99 & $<.0001$ & Tele Norte Celula \\
\hline CS58 & 1 & 2.363 .741 & 397.951 & 5.94 & $<.0001$ & Tele Sudeste Celu \\
\hline
\end{tabular}




\begin{tabular}{|c|c|c|c|c|c|c|}
\hline Variável & $\mathrm{GL}$ & Estimativa & Erro Pad. & Valor $\mathrm{t}$ & $\operatorname{Pr}>|t|$ & Empresas \\
\hline CS59 & 1 & 2.264 .152 & 384.226 & 5.89 & $<.0001$ & Telemar Norte Les \\
\hline CS60 & 1 & 2.849 .723 & 601.437 & 4.74 & $<.0001$ & Telemar \\
\hline CS61 & 1 & 233.443 & 523.966 & 4.46 & $<.0001$ & Telemig Celul Par \\
\hline CS62 & 1 & 1.971 .135 & 376.225 & 5.24 & $<.0001$ & Telemig Celular $\mathrm{P}$ \\
\hline CS63 & 1 & 173.888 & 369.212 & 4.71 & $<.0001$ & Telepar Celular P \\
\hline CS64 & 1 & 2.214 .141 & 460.327 & 4.81 & $<.0001$ & Telesp Cel Part $P$ \\
\hline CS65 & 1 & 2.680 .454 & 566.242 & 4.73 & $<.0001$ & Telesp Operac \\
\hline CS66 & 1 & 2.469 .323 & 458.857 & 5.38 & $<.0001$ & Transmissao Pauli \\
\hline CS67 & 1 & 2.011 .317 & 333.583 & 6.03 & $<.0001$ & Trikem \\
\hline CS68 & 1 & 2.451 .765 & 513.285 & 4.78 & $<.0001$ & Ultrapar \\
\hline CS69 & 1 & 2.095 .951 & 410.470 & 5.11 & $<.0001$ & Unipar \\
\hline CS70 & 1 & 256.746 & 439.529 & 5.84 & $<.0001$ & Usiminas \\
\hline CS71 & 1 & 2.323 .064 & 297.510 & 7.81 & $<.0001$ & $\begin{array}{llll}V & C & P \\
\end{array}$ \\
\hline CS72 & 1 & 2.896 .872 & 498.349 & 5.81 & $<.0001$ & Vale Rio Doce \\
\hline Intercept & 1 & -40.456 & 208.2 & -0.19 & 0.8461 & Varig \\
\hline OWNER_1 & 1 & 0.329286 & 0.4360 & 0.76 & 0.4511 & OWNER_1 \\
\hline OWNER_15 & 1 & 0.097691 & 0.5177 & 0.19 & 0.8505 & OWNER_15 \\
\hline CA_NUM & 1 & -0.87465 & 0.7183 & -1.22 & 0.2249 & CA NUM \\
\hline CA_DIR & 1 & 0.064336 & 0.2069 & 0.31 & 0.7562 & CA_DIR \\
\hline D1_CHAIR & 1 & -258.389 & 131.081 & -0.20 & 0.8440 & D1_CHAIR \\
\hline PERT_AO & 1 & -0.44928 & 0.4775 & -0.94 & 0.3480 & PERT_AO \\
\hline D2_LUCRO & 1 & 1.699 .702 & 124.555 & 1.36 & 0.1741 & D2_LUCRO \\
\hline REMUN_A & 1 & -0.00209 & 0.00189 & -1.11 & 0.2704 & REMUN_A \\
\hline DEB_ASST & 1 & 0.585531 & 0.4148 & 1.41 & 0.1598 & DEB_ASST \\
\hline DIV_PRIC & 1 & 0.013691 & 0.6227 & 0.02 & 0.9825 & DIV_PRIC \\
\hline DIV_EARN & 1 & -0.01618 & 0.0517 & -0.31 & 0.7549 & DIV_EARN \\
\hline D3_AUDIT & 1 & -140.102 & 279.990 & -0.50 & 0.6174 & D3_AUDIT \\
\hline LG_TAM & 1 & -288.943 & 325.427 & -0.89 & 0.3758 & LG_TAM \\
\hline \multicolumn{3}{|c|}{ Método de estimação } & FixOne & \multicolumn{2}{|c|}{$\mathrm{R}^{2}$} & 0.5418 \\
\hline \multicolumn{3}{|c|}{ Teste $F$ para efeitos não fixos } & Valor de $\mathrm{F}$ & 2.34 & Prob $>F$ & $<.0001$ \\
\hline \multicolumn{3}{|c|}{ Teste F para todos os coeficientes } & Valor de $\mathrm{F}$ & 1783429 & Prob $>$ F & $<.0001$ \\
\hline \multicolumn{3}{|c|}{ Teste de Hausman p/ efeitos randôm. } & Valor de $\mathrm{m}$ & 12.93 & Prob > m & 0.4529 \\
\hline \multicolumn{3}{|c|}{ Durbin-Watson } & 2,29 & & & \\
\hline
\end{tabular}

NOTA:

RENT_PL = razão entre o lucro líquido (LL) do exercício considerado e o PL do fim do exercício anterior. $\mathrm{CS}$ = parâmetro do componente de erro singular a cada empresa - secção transversal.

OWNER_1 = fração do capital da empresa, que dá direito a voto, possuída pelo maior acionista controlador, expressa em percentual.

OWNER_15 = representa a fração do capital da empresa, que dá direito a voto, possuída pelos cinco maiores acionistas controladores, expressa em percentual.

CA_NUM = número de integrantes do conselho de administração.

CA_DIR = percentual de integrantes do conselho de administração que também fazem parte da diretoria executiva.

D1_CHAIR = variável dummy utilizada para indicar quando a presidência do conselho de administração e da diretoria executiva são exercidas pela mesma pessoa. A variável assume valor 1 quando a presidência do conselho de administração e a presidência da diretoria executiva são exercidas pela mesma pessoa e 0 quando as duas presidências forem exercidas por pessoas distintas.

PERT_AO = percentual do capital da empresa lastreado em ações ordinárias nominativas.

D2_LUCRO = variável dummy utilizada para indicar quando há participação dos administradores nos lucros da empresa. A variável assume valor 1 quando os administradores têm participação nos lucros auferidos e valor 0 quando não possuem participação nos lucros, isto é, quando a remuneração dos 
executivos independe dos lucros gerados pela companhia.

REMUN_A = remuneração anual total dos administradores expressa em milhares de reais.

DEB_ASST $=$ razão entre o total de recursos de terceiros e o total de ativos da empresa ao final do exercício anterior.

DIV_PRIC = razão entre os dividendos pagos e o preço da ação mais líquida da empresa na Bolsa de Valores de São Paulo. Os dividendos pagos referem-se ao período anterior ao considerado e o preço da ação é do último dia de negociação do período anterior ao considerado.

DIV_EARN = razão entre os dividendos propostos na DOAR e o lucro líquido do período anterior ao considerado.

D3_AUDIT = variável dummy utilizada para indicar quando a empresa de auditoria externa que presta serviços a companhia for Arthur Andersen, Deloitte Touche Tohmatsu, Ernst \& Young, KPMG, Price Waterhouse ou Coopers \& Lybrand. A variável assume valor 1 quando a companhia foi auditada por uma dessas empresas e 0 quando a empresa de auditoria externa foi outra.

LG_TAM = logaritmo do total de ativos ao final do período anterior ao período considerado.

\subsubsection{Modelo de efeitos fixos - duas direções}

$\mathrm{Na}$ regressão com modelo de efeitos fixos e duas direções, com a variável dependente rentabilidade sobre o patrimônio líquido (RENT_PL) foram obtidos os resultados conforme a TABELA 13.

Da mesma forma que a regressão com a mesma variável dependente com efeitos fixos de uma direção, comentada no item anterior, esta regressão é bastante distinta. A captura de efeitos particulares das empresas pelo componente de erro CS (secção transversal) é aqui ainda mais abrangente, excetuando apenas a empresa Varig ao nível de significância de $1 \%$.

Rejeitam-se todas as hipóteses formuladas sobre os mecanismos de Governança Corporativa. Também não se obtém resultado estatisticamente significativo, nem ao nível de $10 \%$, para os parâmetros do componente de erro que capturam os efeitos das passagens de períodos (TS).

A captura de efeitos específicos na empresa Globo Cabo - Net, a segunda exceção do modelo do item anterior, melhorou ligeiramente o coeficiente de correlação múltipla, que passou de 54,18\% para 55,03\%. Esse coeficiente é o segundo menor registrado no estudo. 
TABELA 13 - RESULTADOS DA REGRESSÃO COM RENT_PL COMO VARIÁVEL DEPENDENTE - MODELO DE EFEITOS FIXOS E DUAS DIREÇÕES

\begin{tabular}{|c|c|c|c|c|c|c|}
\hline Variável & $G L$ & Estimativa & Erro Pad. & Valor $\mathrm{t}$ & $\operatorname{Pr}>|t|$ & Empresas \\
\hline$\overline{c S 1}$ & 1 & 2.116 .325 & 419.880 & 5.04 & $<.0001$ & Acesita \\
\hline CS2 & 1 & 1.975 .224 & 396.313 & 4.98 & $<.0001$ & AES Tiete \\
\hline CS3 & 1 & 257.089 & 519.827 & 4.95 & $<.0001$ & Ambev \\
\hline$\overline{c S 4}$ & 1 & 2.502 .285 & 411.553 & 6.08 & $<.0001$ & Aracruz \\
\hline CS5 & 1 & 2.081 .519 & 338.650 & 6.15 & $<.0001$ & Bahia Sul \\
\hline CS6 & 1 & 2.138 .397 & 583.513 & 3.66 & 0.0003 & Bardella \\
\hline CS7 & 1 & 2.328 .759 & 383.045 & 6.08 & $<.0001$ & Belgo Mineira \\
\hline CS8 & 1 & 2.256 .039 & 320.592 & 7.04 & $<.0001$ & Bombril \\
\hline CS9 & 1 & 2.739 .532 & 494.323 & 5.54 & $<.0001$ & Brasil T Par \\
\hline $\mathrm{CS} 10$ & 1 & 255.249 & 392.042 & 6.51 & $<.0001$ & Brasil Telecom \\
\hline$\overline{C S 11}$ & 1 & 2.512 .895 & 503.071 & 5.00 & $<.0001$ & Caemi Metal \\
\hline $\mathrm{CS} 12$ & 1 & 2.322 .239 & 418.186 & 5.55 & $<.0001$ & Celesc \\
\hline $\mathrm{CS} 13$ & 1 & 227.02 & 427.068 & 5.32 & $<.0001$ & Cemig \\
\hline $\mathrm{CS} 14$ & 1 & 2.481 .745 & 499.110 & 4.97 & $<.0001$ & Cesp \\
\hline$\overline{C S 15}$ & 1 & 2.558 .697 & 504.914 & 5.07 & $<.0001$ & Cim Itau \\
\hline CS16 & 1 & 2.515 .147 & 365.066 & 6.89 & $<.0001$ & Coelce \\
\hline $\mathrm{CS} 17$ & 1 & 229.691 & 373.242 & 6.15 & $<.0001$ & Comgas \\
\hline$\overline{C S 18}$ & 1 & 2.313 .414 & 397.035 & 5.83 & $<.0001$ & Confab \\
\hline CS19 & 1 & 2.229 .078 & 428.224 & 5.21 & $<.0001$ & Copel \\
\hline $\mathrm{CS} 20$ & 1 & 2.571 .485 & 430.087 & 5.98 & $<.0001$ & Copene \\
\hline CS21 & 1 & 227.832 & 393.431 & 5.79 & $<.0001$ & Cosipa \\
\hline$\overline{C S 22}$ & 1 & 1.791 .989 & 402.016 & 4.46 & $<.0001$ & Coteminas \\
\hline CS23 & 1 & 2.436 .561 & 503.187 & 4.84 & $<.0001$ & CRT Celular \\
\hline CS24 & 1 & 213.637 & 389.384 & 5.49 & $<.0001$ & Duratex \\
\hline $\mathrm{CS} 25$ & 1 & 2.232 .068 & 551.464 & 4.05 & $<.0001$ & Eletrobras \\
\hline$\overline{\mathrm{CS} 26}$ & 1 & 3.027 .012 & 705.851 & \begin{tabular}{ll|}
4.29 \\
\end{tabular} & $<.0001$ & Eletropaulo Metro \\
\hline CS27 & 1 & 2.529 .809 & 420.490 & 6.02 & $<.0001$ & EMAE \\
\hline CS28 & 1 & 3.247 .468 & 540.788 & 6.01 & $<.0001$ & Embraer \\
\hline $\operatorname{CS} 29$ & 1 & 2.649 .382 & 485.750 & 5.45 & $<.0001$ & Embratel Part \\
\hline CS30 & 1 & 2.032 .093 & 395.915 & 5.13 & $<.0001$ & F Cataguazes \\
\hline CS31 & 1 & 2.331 .134 & 379.654 & 6.14 & $<.0001$ & Fosfertil \\
\hline $\mathrm{CS} 32$ & 1 & 2.405 .709 & 403.091 & 5.97 & $<.0001$ & Gerasul - Tracteb \\
\hline$\overline{C S 33}$ & 1 & 2.437 .023 & 433.336 & 5.62 & $<.0001$ & Gerdau Met \\
\hline CS34 & 1 & 2.122 .073 & 357.623 & 5.93 & $<.0001$ & Gerdau \\
\hline$\overline{C S 35}$ & 1 & 3.256 .113 & 373.735 & 0.87 & 0.3848 & Globo Cabo - Net \\
\hline CS36 & 1 & 1.925 .116 & 383.262 & 5.02 & $<.0001$ & Inepar Construcoe \\
\hline CS37 & 1 & 1.742 .303 & 424.042 & 4.11 & $<.0001$ & Iochp-Maxion \\
\hline CS38 & 1 & 2.207 .908 & 400.765 & 5.51 & $<.0001$ & Ipiranga Pet \\
\hline CS39 & 1 & 3.194 .044 & 749.878 & 4.26 & $<.0001$ & Itausa \\
\hline $\mathrm{CS} 40$ & 1 & 2.115 .731 & 343.878 & 6.15 & $<.0001$ & Klabin \\
\hline $\mathrm{CS} 41$ & 1 & 1.735 .355 & 627.248 & 2.77 & 0.0063 & Kuala \\
\hline $\mathrm{CS42}$ & 1 & 2.616 .761 & 524.530 & 4.99 & $<.0001$ & Light \\
\hline $\mathrm{CS} 43$ & 1 & 2.281 .686 & 463.420 & 4.92 & $<.0001$ & Lojas Americanas \\
\hline$\overline{C S 44}$ & 1 & 2.295 .916 & 504.067 & 4.55 & $<.0001$ & Magnesita \\
\hline CS45 & 1 & 2.361 .825 & 383.631 & 6.16 & $<.0001$ & PETROBRAS BR \\
\hline CS46 & 1 & 2.862 .013 & 625.520 & 4.58 & $<.0001$ & Petrobras \\
\hline $\mathrm{CS} 47$ & 1 & 1.749 .132 & 497.206 & 3.52 & 0.0006 & Plascar \\
\hline
\end{tabular}




\begin{tabular}{|c|c|c|c|c|c|c|}
\hline Variável & $\mathrm{GL}$ & Estimativa & Erro Pad. & Valor $\mathrm{t}$ & $\operatorname{Pr}>|\mathrm{t}|$ & Empresas \\
\hline CS48 & 1 & 2.179 .732 & 329.255 & 6.62 & $<.0001$ & Ripasa \\
\hline CS49 & 1 & 266.825 & 478.647 & 5.57 & $<.0001$ & Sabesp \\
\hline CS50 & 1 & 2.995 .509 & 506.681 & 5.91 & $<.0001$ & Sid Nacional \\
\hline CS51 & 1 & 2.412 .836 & 480.188 & 5.02 & $<.0001$ & Sid Tubarao \\
\hline CS52 & 1 & 2.127 .305 & 394.543 & 5.39 & $<.0001$ & Suzano \\
\hline CS53 & 1 & 2.357 .531 & 435.708 & 5.41 & $<.0001$ & Tele Celular Sul \\
\hline CS54 & 1 & 2.491 .451 & 443.624 & 5.62 & $<.0001$ & Tele Centroeste $\mathrm{C}$ \\
\hline CS55 & 1 & 1.999 .586 & 451.401 & 4.43 & $<.0001$ & Tele Leste Celula \\
\hline CS56 & 1 & 2.307 .654 & 417.486 & 5.53 & $<.0001$ & Tele Nordeste Cel \\
\hline CS57 & 1 & 2.250 .259 & 547.496 & 4.11 & $<.0001$ & Tele Norte Celula \\
\hline CS58 & 1 & 248.676 & 406.176 & 6.12 & $<.0001$ & Tele Sudeste Celu \\
\hline CS59 & 1 & 2.341 .984 & 391.329 & 5.98 & $<.0001$ & Telemar Norte Les \\
\hline CS60 & 1 & 2.879 .027 & 626.417 & 4.60 & $<.0001$ & Telemar \\
\hline CS61 & 1 & 2.527 .418 & 541.802 & 4.66 & $<.0001$ & Telemig Celul Par \\
\hline CS62 & 1 & 2.036 .312 & 389.455 & 5.23 & $<.0001$ & Telemig Celular P \\
\hline CS63 & 1 & 1.812 .144 & 393.277 & 4.61 & $<.0001$ & Telepar Celular P \\
\hline CS64 & 1 & 2.306 .381 & 464.695 & 4.96 & $<.0001$ & Telesp Cel Part $\mathrm{P}$ \\
\hline CS65 & 1 & 2.759 .989 & 590.784 & 4.67 & $<.0001$ & Telesp Operac \\
\hline CS66 & 1 & 2.611 .688 & 467.940 & 5.58 & $<.0001$ & Transmissao Pauli \\
\hline CS67 & 1 & 2.013 .162 & 336.178 & 5.99 & $<.0001$ & Trikem \\
\hline CS68 & 1 & 2.627 .343 & 525.868 & 5.00 & $<.0001$ & Ultrapar \\
\hline CS69 & 1 & 2.192 .039 & 428.184 & 5.12 & $<.0001$ & Unipar \\
\hline CS70 & 1 & 263.621 & 450.363 & 5.85 & $<.0001$ & Usiminas \\
\hline CS71 & 1 & 2.364 .511 & 299.779 & 7.89 & $<.0001$ & $\begin{array}{llll} & C & P \\
\end{array}$ \\
\hline CS72 & 1 & 2.982 .339 & 515.777 & 5.78 & $<.0001$ & Vale Rio Doce \\
\hline TS1 & 1 & 5.893 .688 & 109.943 & 0.54 & 0.5926 & Série Temporal 1 \\
\hline TS2 & 1 & 8.730 .049 & 102.597 & 0.85 & 0.3960 & Série Temporal 2 \\
\hline TS3 & 1 & 2.354 .283 & 98.340 & 0.24 & 0.8111 & Série Temporal 3 \\
\hline TS4 & 1 & -749.619 & 78.226 & -0.96 & 0.3392 & Série Temporal 4 \\
\hline Intercept & 1 & -974.097 & 241.9 & -0.40 & 0.6877 & Varig \\
\hline OWNER_1 & 1 & 0.489117 & 0.4479 & 1.09 & 0.2763 & OWNER_1 \\
\hline OWNER_15 & 1 & 0.021577 & 0.5287 & 0.04 & 0.9675 & OWNER_15 \\
\hline $\mathrm{CA} \_\mathrm{NUM}$ & 1 & -0.81681 & 0.7335 & -1.11 & 0.2670 & $\mathrm{CA} \quad \mathrm{NUM}$ \\
\hline CA_DIR & 1 & 0.154516 & 0.2152 & 0.72 & 0.4737 & CA_DIR \\
\hline D1_CHAIR & 1 & -0.16524 & 134.925 & -0.01 & 0.9902 & D1_CHAIR \\
\hline PERT_AO & 1 & -0.55606 & 0.4844 & -1.15 & 0.2525 & PERT_AO \\
\hline D2_LUCRO & 1 & 1.728 .893 & 126.910 & 1.36 & 0.1748 & D2 LUCRO \\
\hline REMUN_A & 1 & -0.00201 & 0.00195 & -1.03 & 0.3050 & REMUN_A \\
\hline DEB_ASST & 1 & 0.699088 & 0.4243 & 1.65 & 0.1012 & DEB_ASST \\
\hline DIV_PRIC & 1 & -0.19861 & 0.7207 & -0.28 & 0.7832 & DIV_PRIC \\
\hline DIV_EARN & 1 & -0.00105 & 0.0529 & -0.02 & 0.9842 & DIV_EARN \\
\hline D3_AUDIT & 1 & -750.967 & 291.826 & -0.26 & 0.7972 & D3_AUDIT \\
\hline LG_TAM & 1 & -22.831 & 366.730 & -0.62 & 0.5344 & LG TAM \\
\hline \multicolumn{3}{|c|}{ Método de estimação } & FixTwo & \multicolumn{2}{|c|}{$\mathrm{R}^{2}$} & 0.5503 \\
\hline \multicolumn{3}{|c|}{ Teste F para efeitos não fixos } & Valor de F & 2.25 & Prob > F & $<.0001$ \\
\hline \multicolumn{3}{|c|}{ Teste de Hausman $\mathrm{p} /$ efeitos randôm. } & Valor de $\mathrm{m}$ & 14.72 & Prob > m & 0.3254 \\
\hline \multicolumn{3}{|c|}{ Durbin-Watson } & 2,29 & & & \\
\hline
\end{tabular}

NOTA:

RENT_PL = razão entre o lucro líquido $(\mathrm{LL})$ do exercício considerado e o PL do fim do exercício anterior. 
CS = parâmetro do componente de erro singular a cada empresa - secção transversal.

TS = parâmetro do componente de erro que capta os efeitos das diferenças intertemporais das secções transversais. TS1, por exemplo, capta as diferenças intertemporais entre os anos 1997 e 1998. É igual para todas as empresas de uma mesma secção transversal.

OWNER_1 = fração do capital da empresa, que dá direito a voto, possuída pelo maior acionista controlador, expressa em percentual.

OWNER_15 = representa a fração do capital da empresa, que dá direito a voto, possuída pelos cinco maiores acionistas controladores, expressa em percentual.

CA_NUM = número de integrantes do conselho de administração.

CA_DIR = percentual de integrantes do conselho de administração que também fazem parte da diretoria executiva.

D1_CHAIR = variável dummy utilizada para indicar quando a presidência do conselho de administração e da diretoria executiva são exercidas pela mesma pessoa. A variável assume valor 1 quando a presidência do conselho de administração e a presidência da diretoria executiva são exercidas pela mesma pessoa e 0 quando as duas presidências forem exercidas por pessoas distintas.

PERT_AO = percentual do capital da empresa lastreado em ações ordinárias nominativas.

D2_LUCRO = variável dummy utilizada para indicar quando há participação dos administradores nos lucros da empresa. A variável assume valor 1 quando os administradores têm participação nos lucros auferidos e valor 0 quando não possuem participação nos lucros, isto é, quando a remuneração dos executivos independe dos lucros gerados pela companhia.

REMUN_A = remuneração anual total dos administradores expressa em milhares de reais.

DEB_ASST $=$ razão entre o total de recursos de terceiros e o total de ativos da empresa ao final do exercício anterior.

DIV_PRIC = razão entre os dividendos pagos e o preço da ação mais líquida da empresa na Bolsa de Valores de São Paulo. Os dividendos pagos referem-se ao período anterior ao considerado e o preço da ação é do último dia de negociação do período anterior ao considerado.

DIV_EARN = razão entre os dividendos propostos na DOAR e o lucro líquido do período anterior ao considerado.

D3_AUDIT = variável dummy utilizada para indicar quando a empresa de auditoria externa que presta serviços a companhia for Arthur Andersen, Deloitte Touche Tohmatsu, Ernst \& Young, KPMG, Price Waterhouse ou Coopers \& Lybrand. A variável assume valor 1 quando a companhia foi auditada por uma dessas empresas e 0 quando a empresa de auditoria externa foi outra.

LG_TAM = logaritmo do total de ativos ao final do período anterior ao período considerado. 


\section{Capítulo V}

\section{CONCLUSÕES E SUGESTÕES PARA NOVOS ESTUDOS}

\subsection{CONCLUSÕES}

Com uma amostra de 73 empresas integrantes do Índice Brasil - IBX da Bolsa de Valores de São Paulo - BOVESPA e dados coletados dos demonstrativos financeiros e informações anuais enviados pelas empresas à Comissão de Valores Mobiliários e dados do provedor de informações ECONOMATICA, objetivou-se neste trabalho identificar possíveis relações entre variáveis independentes representativas de mecanismos de Governança Corporativa e medidas de performance econômica. Foram estudadas 16 variáveis independentes representando os mecanismos de Governança concentração de propriedade (5 variáveis), características do conselho de administração (3 variáveis), capital votante (1 variável), remuneração da diretoria executiva (2 variáveis), política financeira (3 variáveis), controle interno (1 variável) e mais uma variável de controle representando o tamanho das empresas. Essas variáveis foram regredidas, com a técnica estatística de dados em painel modelo de componentes de erros, contra cada uma das cinco variáveis de medidas de performance econômica estudadas. Tais variáveis mediram o Market Value Added, a razão preço de mercado e valor patrimonial da ação, TOBIN'S Q, rentabilidade sobre o ativo e rentabilidade sobre o patrimônio líquido. 
Todas as hipóteses formuladas implicavam relacionamento positivo das variáveis independentes com as medidas de performance econômica, exceção feita apenas às variáveis independentes que representaram o mecanismo de Governança Corporativa características do conselho de administração, cujo relacionamento suposto foi negativo.

A primeira hipótese, concernente à concentração de propriedade, não pôde ser rejeitada ao nível de significância de 5\%, para as medidas de performance razão entre o preço de mercado e valor patrimonial da ação e TOBIN'S Q. Dessa forma não se pode afirmar que a concentração de propriedade, expressa pela posse de ações com direito a voto do maior acionista, não influencia positivamente a performance econômica das empresas.

As variáveis representativas do mecanismo de Governança características do conselho de administração não apresentaram relacionamento estatisticamente significativo com nenhuma das medidas de performance estudadas, culminando com a rejeição da segunda hipótese do estudo que preconizava que o número de integrantes do conselho de administração, o exercício duplo da presidência do conselhos de administração e da presidência da diretoria executiva e o percentual de integrantes do conselho de administração que também exercem funções na diretoria executiva estariam inversamente relacionados às medidas de performance.

O percentual de ações do capital das empresas que dá direito a voto, objeto da terceira hipótese do trabalho, resultou estatisticamente significativo ao nível de pelo menos $5 \%$ quando regredido contra as medidas de performance razão entre o preço de mercado e valor patrimonial da ação e TOBIN'S Q. Surpreendeu, no entanto, o fato de o relacionamento ser negativo e não positivo como descrito na hipótese. Esperava-se que aumentos no percentual de ações do capital que dá direito a voto implicasse também aumentos nas medidas de performance econômica abordadas. Contudo, os resultados indicam que não se pode rejeitar a hipótese de que aumentos no percentual 
de ações do capital que dá direito a voto estão relacionados a decréscimos de performance, quando esta é medida pela razão entre o preço de mercado e valor patrimonial da ação ou TOBIN'S Q.

A quarta hipótese do trabalho expressava que a remuneração total da diretoria executiva e a existência de programas de remuneração baseados em lucro deveriam estar positivamente relacionadas às medidas de performance econômica. Os resultados evidenciaram que a existência de programas de remuneração baseados em lucro foi a variável que mostrou-se estatisticamente significante, ao nível de $10 \%$ pelo menos, no maior número de testes, relacionando-se positivamente com Market Value Added, com a razão entre o preço de mercado e valor patrimonial da ação e com TOBIN'S Q. A variável representativa da remuneração total da diretoria executiva resultou estatisticamente relacionada com a razão entre o preço de mercado e valor patrimonial da ação e com TOBIN'S Q, ao nível de significância de 5\%. Esse é mais um resultado que surpreendeu porque não se esperava que remunerações mais altas dos executivos estivessem associadas às medidas de performance declinantes.

Das variáveis referentes ao mecanismo de Governança política financeira, objeto da quinta hipótese, apenas a variável dividend yield foi estatisticamente significativa ao nível de $10 \%$ e somente quando regredida contra a medida de performance TOBIN'S Q. A hipótese expressava que o endividamento das empresas, o dividend yield e o pay out estariam positivamente relacionados com as medidas de performance econômica mas foi rejeitada em todas as regressões, com exceção do resultado relatado no início deste parágrafo.

Por fim, a sexta hipótese do trabalho preconizava que empresas auditadas por grandes companhias de auditoria, que presumivelmente teriam mais competência para detectar irregularidades nas demonstrações financeiras e maior independência para reportar esses achados, tenderiam a ter melhor performance. A hipótese foi rejeitada para todas as medidas de performance econômica testadas. 
Se abordarmos os resultados do trabalho por outra ótica, podemos constatar que:

- para a medida de performance Market Value Added somente a variável que representava a presença de programas de remuneração de executivos baseada em lucros foi estatisticamente significativa, ao nível de 5\%;

- para a medida de performance dada pela razão entre o preço de mercado e valor patrimonial da ação (P_VPA) obteve-se quatro variáveis estatisticamente significantes. A concentração de propriedade, ao nível de $5 \%$, o percentual de ações do capital das empresas que dá direito a voto, ao nível de pelo menos $5 \%$ e surpreendendo com o sinal do relacionamento, a existência de programas de remuneração dos executivos baseada em lucros, ao nível de pelo menos $10 \%$ e a remuneração total da diretoria executiva, ao nível de 5\%, também surpreendendo com o sinal do relacionamento.

- para a medida de performance TOBIN'S Q os resultados são muito similares aos obtidos para a medida dada pela razão entre o preço de mercado e valor patrimonial da ação (P_VPA). A matriz de correlações das variáveis analisadas no item 2 do capítulo IV já oferecia essa indicação. Os resultados diferem apenas porque a existência de programas de remuneração de executivos baseada em lucros dá lugar à variável dividend yield, estatisticamente significativa ao nível de $10 \%$.

- para as medidas de performance econômica rentabilidade sobre o ativo e rentabilidade sobre o patrimônio líquido nenhuma variável, de nenhum mecanismo de Governança, resultou estatisticamente significativa até o nível de $10 \%$.

A análise dos resultados do trabalho permitiu também observar que a medida de performance econômica utilizada faz diferença no estudo dos mecanismos de 
Governança Corporativa, haja vista não se ter encontrado nenhuma variável estatisticamente significativa para as medidas rentabilidade sobre o ativo e rentabilidade sobre o patrimônio líquido, ao passo que para as demais, pelo menos uma variável foi estatisticamente significante. De se notar, também, que as medidas que não apresentaram nenhum resultado significativo são puramente contábeis, enquanto as demais são híbridas, isto é possuem componentes contábeis e componentes de mercado. Mais especificamente, a medida Market Value Added possui um componente de mercado, preços das ações, e um componente contábil que é o

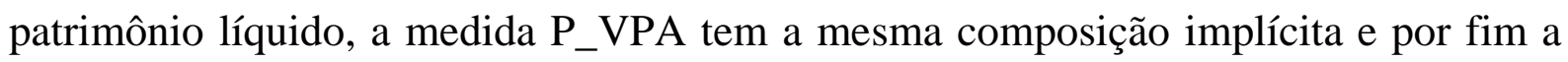
medida TOBIN'S Q possui o componente de mercado preço das ações e o componente contábil do total de ativos. Dentre as conclusões de Lopes (2001, p. 216-217) encontra-se a que evidencia que o lucro contábil no Brasil não reconhece significativamente o comportamento do resultado econômico e que o conteúdo informativo oferecido ao mercado pela contabilidade financeira brasileira está contido, quase que exclusivamente, nos números do patrimônio. Talvez estejam aqui as razões que justificam não se ter encontrado resultados estatisticamente significativos para as medidas de performance econômica rentabilidade sobre o ativo e rentabilidade sobre o patrimônio líquido, pois são exatamente as duas medidas que contém o lucro líquido em sua composição. As medidas que contém o patrimônio líquido em suas composições e não contém o lucro líquido, produziram resultados estatisticamente significativos.

Outro ponto relevante que se registra nestas conclusões é que os mecanismos de Governança Corporativa podem ser substitutivos uns dos outros e/ou serem combinados em proporções distintas. Por conseguinte, é improvável que exista uma estrutura ótima de Governança que seja única. Isto é, a estrutura ótima de Governança, se existe, não é única, pois diversas combinações de mecanismos e em diferentes proporções podem produzir uma estrutura ótima 
Este estudo, com esta abrangência de mecanismos, variáveis e período tratado, está dentre os estudos empíricos de Governança Corporativa pioneiros no Brasil. Sob o ponto de vista teórico, contribui com a reunião de diversas facetas que vai além da clássica teoria da agência, abordando também a assimetria da informação, a teoria da firma e a contextualização do estudo de Governança Corporativa no âmbito da Contabilidade. Sob o ponto de vista prático, oferece a acionistas, gestores, analistas de mercado, consultores, administradores de Bolsa de Valores, órgãos reguladores e associações de classe, evidências empíricas sobre a relação entre os mecanismos de Governança Corporativa e performance que poderão ser consideradas nos seus processos decisórios

\subsection{SUGESTÕES PARA NOVOS ESTUDOS}

O tema Governança Corporativa está em sua infância no mundo e no Brasil é embrionário. Este estudo integra as primeiras pesquisas empíricas com empresas brasileiras, porém há muito a ser feito no campo acadêmico.

Sugere-se, em estudos subseqüentes:

- testar hipóteses relacionadas à concentração de propriedade em investidores institucionais como por exemplo: H: Empresas que possuem dentre os maiores acionistas fundos de pensões de funcionários de empresas estatais, tendem a ter performance econômica menor do que as que possuem fundos de pensões de empresas privadas ou não possuem investidores institucionais;

- testar hipóteses relacionadas a investidores caracterizados como instituições financeiras. Empresas com participações acionárias de instituições financeiras tendem a ter melhores performances econômicas do que as empresas que não possuem acionistas dessa natureza; 
- elaborar modelos tratáveis com equações simultâneas;

- averiguar influência de proprietários internos;

- testar práticas de remuneração do diretor presidente e da diretoria executiva;

- testar a eficácia das práticas de Governança estabelecidas pela Bolsa de Valores de São Paulo para empresas que integram os níveis 1 e 2 de Governança Corporativa e o Novo Mercado;

- testar a influência dos conselhos fiscais instalados;

- aprofundar estudos com as variáveis de mecanismos de Governança com as variáveis percentual de ações do capital das empresas que dá direito a voto e remuneração da diretoria executiva, em especial por terem apresentado resultados surpreendentes no presente trabalho. 


\section{BIBLIOGRAFIA}

AGGARWAL, R. Using economic profit to assess performance: a metric for modern firms. Business Horizons, v. 44, n. 1, Jan./Feb. 2001.

AGRAWAL, A.; KNOEBER, C. R. Firm performance and mechanisms to control agency problems between managers and shareholders. The Journal of Financial and Quantitative Analysis, v. 31, n. 3, p. 377-397, Sept. 1996.

AGRAWAL, A.; MANDELKER, G. N. Large shareholders and the monitoring of managers: the case of antitakeover charter amendments. The Journal of Financial and Quantitative Analysis, v. 25, n. 2, p. 143-161, June 1990

AKERLOF G. The market for lemons: quality uncertainty and the market mechanism., Quarterly Journal of Economics, v.84, p. 485-500, 1970.

ALCHIAN, A. A.; DEMSETZ, H.. Production, information costs, and economic organization. American Economic Review, v. 62, n. 5, p. 777-795, Dec. 1972.

ALCHIAN, A. A.; DEMSETZ, H. The property right paradigm., The Journal of Economic History, v. 33, n. 1, p. 16-27, Mar. 1973.

ALI, A.; HWANG, Lee-Seok. Country-specific factors related to financial reporting and the value relevance of accounting data. Journal of Accounting research, v. 38, n. 1, p. 1-21, Spring, 2000.

ALLAN, P.; WIDMAN, A.. A comparison of the views of CEOs and public pension funds on the corporate governance issues of chairman-CEO duality and election of lead directors. American Business Review, v. 18, p. 49-54, Jan. 2000.

ALMEIDA, F. G.; ALMEIDA, L. C. de; NESS Jr., W. L.. A Governança Corporativa no setor de telecomunicações brasileiro. In: II Encontro Brasileiro de Finanças, Rio de Janeiro, 22 e 23 jul. 2002.

ANUATTI NETO, F.; BAROSSI FILHO , M.; CARVALHO, A. G. de; MACEDO, R.. Financial and operational performances of newly privatized firms in brazil: a panel data analysis. In: II Encontro Brasileiro de Finanças, Rio de Janeiro, 22 e 23 jul. 2002.

BAKER, G. P.; GIBBONS, R. S.; MURPHY, K. J. Contracts and the theory of the firm. Harvard Business School. National Bureau of Economic Research (NBER), Dec. 1997.

BAKER, G. P.; GIBBONS, R. S.; MURPHY, K. J. Implicit contracts and the theory of the firm. University of Southern California, Working Paper, Sept. 1997.

BALIGA, B. R.; MOYER, R. C.; RAO, R. S. CEO duality and firm performance; what's the fuss? Strategic Management Journal, v. 17, n. 1. p. 41-53, Jan. 1996.

BALTAGI, B. H. Econometric analysis of panel data. England: John Wiley, 1995.

BARKEMA, H. G.; GOMEZ-MEJIA, L R. Managerial compensation and firm performance: 
a general research framework. Academy of Management Journal, v. 41, n. 2, p. 135-146, Apr 1998.

BARNHART, S. W. Board composition, managerial ownership, and firm performance: an empirical analysis. The Financial Review, Tallahassee, lv. 33, n. 4, p. 1-16, Nov. 1998.

BARNHART, S. W.; ROSENSTEIN, S. Board composition, managerial ownership, and firm performance: an empirical analysis. The Financial Review, v.33. p. 1-16, Nov. 1998.

BARNHART, S. W.; MARR, M. W.; ROSENSTEIN, S. Firm performance and board composition: some new evidence. Managerial and decision economics, v. 15, n. 4, Special Issue: Aspects of Corporate Governance, p. 329-340, Jul-Aug., 1994.

BAYESINGER, B. D.; HOSKISSON, R. E. The composition of boards of directors and strategic control: effects on corporate strategy. Academy of Management Review, v. 15, n. 1, p.72-87, Jan. 1990.

BAYSINGER, B. D.; HOSKISSON, R. E. The composition of boards of directors and strategic control: effects on corporate strategy. Academy of Management Review, v. 15, n. 1, p. 72-87, 1990.

BAYSINGER, B. D.; KOSNIK, R. D.; TURK, T. A. Effects of board and ownership structure on corporate R\&D strategy. Academy of Management Journal, 34, 205-214, 1991.

BEATTY, R. P.; ZAJAC, E. J. Managerial incentives, monitoring and risk bearing: a study of executive compensation, ownership, and board structure in initial public offerings. Administrative Science Quarterly, v. 39, p. 313-335, 1994.

BECK, N.; KATZ, J. N. Random coefficient models for time-series-Cross-Section. Annual Meeting of the Societyfor Political Methodology, Emory University, Draft of July 2001.

BERLE, A. A.; MEANS, G. C. The modern corporation \& private property. 4. ed. New Brunswick, NJ: Transaction Publishers, 2002. Original publicado em 1932 por Harcourt, Brace \& World.

BHAGAT, S.; BLACK, B. S. The uncertain relationship between board composition and firm performance. Business Lawyer, v. 54, p. 921-963, 1999.

BHARGAVA, A.; FRANZINI, L. NARENDRANATHAN, W. Serial correlation and the fixed effects model. The Review of Economic Studies, v. 49, n. 4, p. 533-549, Oct. 1982.

BIDDLE, G. C.; BOWEN, R. M.; WALLACE, J. Evidence on EVA? Journal of Applied Corporate Finance, v. 12, n. 2, Summer, 1999.

BLACK, B. The corporate governance behavior and market value of russian firms. Stanford Law School draft Mar. 2001 Emerging Markets Review, vol. 2, Working Paper 212, forthcoming 2001.

BLAIR, M. M. Ownership and control: rethinking coporate governance for the twenty-first century. Washington: Brookings, 1995.

BLOCK , S. The role of nonaffiliated outside directors in monitoring the firm and the effect on shareholder wealth. Journal of Financial and Strategic Decisions, v. 12, n. 1, Spring 1999.

BOHREN, O.; ODEGAARD, B. A. Corporate governance and economic performance in Norwegian listed firms. Nov. 26, 2001. Disponível em: 
http://finance.bi.no/ governance/perf-report.pdf . Acesso em: dez., 2001.

BOLSA DE VAlORES DE SÃO PAUlO. Novo Mercado. Disponível em: <http://www.novomercadobovespa.com.br/>. Acesso em: jan. 2001.

BOLSA DE VALORES DE SÃO PAULO. Novo mercado: BOVESPA - Brasil. Disponível em: <http://www.bovespa.com.br/> Acesso em: maio 2002.

BOROKHOVICH, K. A. Outside directors and CEO selection. Journal of Financial and Quantitative Analysis, Seattle, v. 31, n. 3; p. 337-355, Sept. 1996.

BOWEN, R. M.; RAJGOPAL, S; VENKATACHALAM, M.. Accounting choice, corporate governance and firm performance. Disponível em: <http://papers. ssrn.com/sol3/papers.cfm?abstract_id=367940\#Paper\%20Download>Acesso em: abr. 2003, Jan. 2002

BOYD, B. K. Board control and CEO compensation. Strategic Management Journal, v. 15, n. 5, p.335-344, Jun, 1994.

BOYD, B. K. CEO duality and firm performance: a contingency model. Strategic Management Journal, v. 16, n. 4. p. 301-312, May 1995.

BRADLEY, M.; JARRELL, G. A.; KIM, E. H. On the existence of optimal capital structure: theory and evidence. Papers and Proceedings of the Forty-Second Annual Meeting,American Finance Association, São Francisco, CA, Dec. 28-30. The Journal of Finance. v. 39, n. 3, p. 857-878, July 1984.

BRATTON, W. W. Berle and Means reconsidered at the century's turn. Journal of Corporation Law, Iowa City, v. 26, n. 3; p. 737-770, Spring, 2001.

BRICKLEY, J. A.; COLES, J. L.; JARRELL, G. Leadership structure: separating the CEO and chairman of the board. Journal of Corporate Finance, v. 3, p. 189-220, 1997.

BRICKLEY, J. A.; COLES, J. L.; TERRY, R. L. The board of directors and the enactment of poison pills. Journal of Financial Economics, v. 35, p. 371-390, 1994.

BURKART, M. Large shareholders, monitoring, and the value of the firm. The Quarterly Journal of Economics, Cambridge, v. 112, n. 3, p. 693-728, Aug. 1997.

BUSHMAN, R. M.; SMITH, A. J.. Financial accounting information and corporate governance. Journal of Accounting \& Economics, v. 32, n. 1-3, Dec. 2001.

CAHAN, S. F.; WILKINSON, B. R. Board composition and regulatory change: evidence from the enactment of new companies' legislation in New Zealand. Financial Management, v. 28, n. 1, Spring 1999.

CAPON, N.; FARLEY, J. U.; HOENIG, S.. Determinantws of financial performance: a metaanalysis. Management Science, v. 36, n. 10, p. 1143-1159, Oct., 1990.

CARVAlHO, A. G. de. Ascensão e declínio do mercado de capitais no brasil: a experiência dos anos 90. Universidade de Brasília. Seminário no 25/00 - 05/10/00. Disponível em: <www.unb.br/ih/eco/seminarios/sem2500.pdf> Acesso em: Out. 2002.

CARVALHO, A. G. de. Efeittos da migração para os níveis de governança da BOVESPA. Trabalho preparado para a BOVESPA. Disponível em: <http://www.econ.fea.usp.br/gledson/artigo.asp>. Acesso em: jan. 2003. 
CARVAlHO, A. G. de. Governança Corporativa no brasil em perspectiva. Revista de Administração da USP, v.37, n. 3, 2002.

CARVALHOSA, M.; EIZIRIK, N. A nova lei das S/A. São Paulo: Saraiva, 2002.

CHAKRAVARTHY, B. S. Measuring strategic performance. Strategic Management Journal, v. 7, n. 5, p. 437-458, Sept.-Oct., 1986.

COASE, R. H. The firm, the market and the law. 2. ed. USA: The University of Chicago Press, 1990.

COASE, R. H. The nature of the firm. Economica. New Series, v. IV, p.386-405, 1937.

COCHRAN, P. L.; WOOD, R. A. Corporate social responsibility and financial performance. The Academy of Managemente Journal, v. 27, p. 42-56, Mar. 1984.

COHEN, K. J.; CYERT, R. M. Theory of the firm: resource allocation in a market economy. New Jersey: Prentice Hall, 1975.

COLES, J. W.; HESTERLY, W. S. Independence of the chairman and board composition: firm choices and shareholder value. Journal of Management, v. 26, n. 2, p. 195-215, 1999.

COLES, J. W.; MCWILLIAMS, V. B.; SEN, N. An examination of the relationship of governance mechanisms to performance. Journal of Management, v. 27, n. 1, p. 23-50. Jan. 2001.

COMISSÃO DE VALORES MOBILIÁRIOS. Recomendações da CVM sobre governança corporativa. Disponível em: <cvm.gov.br>. Acesso em: ago. 2002.

DAILY, C. M . On the measurements of board composition: poor consistency and a serious mismatch of theory and operationalization. Decision Sciences, Atlanta, v. 30, n. 1, p. 83-106, Winter, 1999.

DAILY, C. M. Board of directors leadership and structure: control and performance implications. Entrepreneurship Theory and Practice, v. 17, n. 3; p. 65-81, Spring, 1993.

DAILY, C. M. CEO and board chair roles held jointly or separately: much ado about nothing? The Academy of Management Executive, Briarcliff Manor, v. 11, n. 3; p. 11-20, Aug. 1997.

DALTON, D. R. Composition and CEO duality in boards of directors: an international perspective. Journal of International Business Studies, Washington, v. 18, n. 3, p. 33-43, Fall, 1987.

DALTON, D. R. et. al Meta-analytical reviews of board composition, leadership structure, and financial performance, Strategic Management Journal, v. 9, p. 269-290, 1998.

DALTON, D. R. Number of directors and financial performance: a meta-analysis. Academy of Management Journal, v. 42, n. 6; p. 674-686, Dec. 1999.

DAVIS, J. H.; SCHOORMAN, F. D.; DONALDSON, L. Toward a stewardship theory of management. Academy of Management Review, v. 22, p. 20-47, 1997.

DEMSETZ, H. Property rights and behavior: toward a theory of property rights. Papers and Proceedings of the Seventy-Ninth Annual Meeting of the American Economic Association.The American Economic Review, v. 57, n. 2, p. 347-359, May 1967. 
DEMSETZ, H. The cost of transacting. The Quarterly Journal of Economics, v. 82, n. 1, p. 33-53, Feb. 1968.

DEMSETZ, H. The firm in economic theory: a quiet revolution. The American Economic Review, v. 87, n. 2, p. 426-429, May 1997.

DEMSETZ, H.; LEHN, K. The structure of corporate ownership: causes and consequences. The Journal of Political Economy, v. 93, n. 6. p. 1155-1177, Dec. 1985.

DEMSETZ, H.; VILLALONGA, B. Ownership structure and corporate performance. Journal of Corporate Finance, v. 7, p. 209-233, 2001.

DEMSETZ, H. The Structure of Ownership and The Theory of the Firm. The Journal of Law and Economics. Vol 26(pp.375-390). University of Chicago. Estados Unidos. June 1983.

DENIS, D. K.; MCCONNELL, J. J. International corporate governance: a servey. Krannert Graduate School of Management Purdue University. Working Paper, June 2002.

DONALDSON, L.; DAVIS, J. H. stewardship theory or agency theory: ceo governance and shareholder returns. Journal of Management, Australian, v.16, n. 1, June 1991.

DRAPER, N. R.; SMITH, H. Applied regression analysis. New York, London, Sydney: John Wiley, 1966.

DROBETZ, W. Corporate governance - legal fiction or economic reality? University of Basel, WWZ/Department of Finance, Working Paper n. 1/03, Jan. 2003

DUTRA, M. G. L.; SAITO, R. Conselhos de administração: análise de sua composição em um conjunto de companhias abertas brasileiras. In: Primeiro Encontro Brasileiro de Finanças, jul. 2001.

EES, H. van; POSTMA, Theo J. B. M.; STERKEN, E.. Board compositions and firm performance in the Netherlands. University of Groningen, Netherlands, Working Paper. Jan. 2002.

EISENBERG, T. SUNDGREN, S.; WELLS, M.T. Larger board size and decreasing firm value in small firms. Journal of Financial Economics, v. 48, p.35-54, 1998.

ELHORST, J. P. Panel data models extended to spacial error correlation or a spacially lagged dependent variable. Faculty of Economics, University of Groningen, TheNetherlands, Working Paper. June 2002.

EQUIPE ATLAS. Lei das S.A.:Lei n. 6.404, de 15 de dezembro de 1976, Lei n. 10.303, de 31.10.2001. 8. ed. São Paulo: Atlas, 2002.

FAMA, E. F.; JENSEN, M. C. Separation of ownership and control. Journal of Law and Economics, v. 26, p. 301-326, June 1983a.

FAMA, E. F.; JENSEN, M. C. Agency problems and residual claims. Journal of Law and Economics, v. 26, p. 327-349, June 1983b.

FAMA, E. F. Agency problems and the theory of the firm. Journal of Politicial Economy, v. 88, p. 288-307, 1980.

FAMA, E. F.; JENSEN, M. C. Organizational forms and investment decisions. Journal of Financial Economics, v. 14, p. 101-119, 1985. 
FAMA, E. F.; FRENCH, K. R.. Taxes, financing decisions, and firm value. http://papers.ssrn.com/sol3/delivery.cfm/9701204.pdf? abstractid=1871. Acesso em: maio 2002.

FERGUSON, C. E. Microeconomia. Tradução: Almir Guilherme Barbassa; Antonio Pessoa Brandão. 18. ed. Rio de Janeiro: Forense, 1994. Tradução de: Microeconomic theory.

FINKELSTEIN, S.; D'AVENI, R. A. CEO duality as a double-edged sword: how boards of directors balance entrenchment avoidance and unity of command. Academy of Management Journal, v. 37, p. 1079-1108, 1994.

FOSS, N. J. Incomplete Contracts and Economic organization: Brian Loasby and the theory of the firm. Danish Research Unit For Industrial Dynamics. Working Paper n.. 97-11 Oct. 1997.

FOSS, N. J. Real options and the theory of the firm. Department of Industrial Economics and Strategy. Copenhagen Business School, Copenhagen, Denmark. Paper prepared for Ron Sanchez, ed., February, 1998. Disponível em: <http://www.cbs.dk/departments/ivs/wp/wp983.pdf >. Acesso em: 07 de outrubro de 2002.

FOSS, N. J.; LANDO, H.; The theory of the firm. Steen Thomsen Copenhagen Business School. Working Paper, Aug. 1998.

GEDDES, R.; VINOD, H. CEO tenure, board composition and regulation. Social Science Research Network, Working paper, 1998.

GIBBONS, R. Incentives in organizations. The Journal of Economic Perspectives, v. 12, n. 4, p. 115-132, Autumn, 1998.

GOETZMANN, W. N.; GARSTKA, S. J. The development of corporate performance measures: benchmarks before $\mathbf{E V A}^{\mathbf{T M}}$. Yale School of Management, Working Paper, July 1999.

GOMES, A.; NOVAES, W.. Sharing of control as a corporate governance mechanism. The Rodney L. White Center for Financial Research, The Wharton School, University of Pennsylvania, Working Paper, Dec. 2000.

GOMPERS, P. A.; ISHII, J. L.; METRICK, A.. Corporate governance and equity prices. University of Pennsylvania, National Bureau of Economic Research (NBER), Working Paper, July 2001.

GREGORY, H. J. The globalisation of corporate governance. Global Counsel, 2000. Disponível em: <http://rru.worldbank.org/documents/globalisation_of_corporate_governan ce.pdf >. Acesso em: 10 maio 2003.

GREENE, W. H. Econometric analysis. 4.ed. New Jersey: Prentice Hall, 2000.

Greenwald, B. C.; STIGLITZ, J. E. Asymmetric information and the new theory of the firm: financial constraints and risk behavior. Papers and Proceedings of the Hundred and Second Annual Meeting of the American Economic Association. The American Economic Review, v.80, n. 2, p. 160-165, May 1990.

GUGLER, K. Corporate governance and economic performance. Oxford, UK: Oxford University Press, 2001.

GUJARATI, D. N. Econometria básica. 3. ed. São Paulo: Makron Books, 2000. 
HAIR, J. F. , ANDERSON, R. E., TATHAM, R. L. et. al. Multivariate data analysis. 5.ed. New Jersey: Prentice-Hall, 1998.

HARM, C.. The limits of corporate governance: an examination of the managershareholder conflict. University of Münster, Working Paper, Sept. 2000. Disponível em: < www.wiwi.uni-muenster.de/iw/forschung/ Manager-Shareholder\%20Conflict.pdf>. Acesso em: jan. 2003.

HARM, C.The board of director. University of Münster, Working Paper, Sept. 2000.

HART, O. Corporate Governance: Some theory and implications. The Economic Journal, v. 105, p. 678-689, May, 1995.

HART, O. Firms, contracts and financial structure. Oxford: Oxford University Press, 1995.

HART, O.; MOORE, J. Foundations of incomplete contracts. The Review of Economics Studies, v. 66, n. 1, Special Issue: Contracts, p. 115-138, Jan. 1999.

HART, O.; MOORE, J. Property rights and nature of the firm. The Journal of Political Economy, v. 98, n. 6, p. 1119-1158, Dec. 1990.

HARVEY, K. D.; SHRIEVES, R. E. Executive compensation structure and corporate governance choices. The University of Tennessee, Working Paper, Jan. 2000.

HAUSMANN, J. A. Specification tests in econometrics. Econometrica. v. 46, n. 6, p. 12511271, Nov. 1978.

HAWLEY, J. P.; WILLIAMS, A. T. Corporate governance in the united states: the rise of fiduciary capitalism a review of the literature. Prepared for the Organization for Economic Cooperation and Development, Paris, France., Jan. 1996.

HEFLIN, F. Blockholder ownership and market liquidity. Journal of Financial and Quantitative Analysis, Seattle,; v. 35, n. 4, p. 621-633, Dec. 2000.

HENDRIKSEN, E. S.; BREDA, M. F. Van. Accounting theory. 5. ed. USA: Irwin, 1992.

HERMALIN, B. E.; WEISBACH, M. S. The effects of board composition and direct incentives on firm performance. Financial Management , v. 20, n. 4, p. 101-112, Winter, 1991.

HERMALIN, B. E.; WEISBACH, M.S. Endogenously chosen boards of directors and their monitoring of the CEO. American Economic Review, v. 88, p. 96-118, Mar. 1998.

HERMALIN, B. E.; WEISBACH, M. S. Boards of directors as an endogenously determined institution: a survey of the economic literature. Harvard Business School. National Bureau of Economic Research (NBER), Working Paper, n. W8161, Mar. 2001.

HERZBERG, F.; MAUSNER, B.; SNYDERMAN, B. B. The Motivation to Work . New York: John Wiley, 1959.

HILL, C. A.; SNELL, S. A. Effects of ownership structure and control on corporate productivity. Academy of Management Journal, v. 32, p. 25-46, 1989.

HILL, R. C.; GRIFFITHS, W. E.; JUDGE, G. G. Econometria. Tradução: Alfredo Alves de Farias. 2. ed. São Paulo: Saraiva, 2003. Tradução de: Undergraduate econometrics. 
HOBBS, R. Stakeholding and corporate governance: theory and evidence on economic performance. ESRC Centre for Business Research, University of Cambridge, Working Paper, Nov. 2000.

HOLDERNESS, C. G.. A survey of blockholders and corporate control. Boston College Carroll School of Management. Economic Policy Review ( Forthcoming). Sept. 2001.

HOLDERNESS, C. G.; SHEEHAN, Dennis. The role of majority shareholders in publicly held corporations: an exploratory analysis. Journal of Financial Economics, v. 20, p. 317346, 1988.

HSIAO, C.. Analysis of panel data. Cambridge: Cambridge University Press, 2003.

HUNT, E. K.. História do pensamento econômico. 14. ed. Rio De Janeiro: Editora Campos, 1981.

IMHOFF, G. Accounting quality, auditing and corporate governance. University of Michigan Business School. Jan. 2003. Disponível em: http://papers.ssrn.com /sol3/papers.cfm?abstract_id=374380 Acesso em: abr. 2003

INSTEFJORD, N. The market for corporate control and the agency paradigm ? European Finance Review, Netherlands, v. 3, p. 1-22, 1999.

INSTITUTO BRASILEIRO DE GEOGRAFIA E ESTATÍSTICA. Disponível em : <http://www.ibge.gov.br>. Acesso em: ago. 2002.

INSTITUTO BRASILEIRO DE GOVERNANÇA CORPORATIVA. Disponível em: <http://www.ibgc.org.br/ibConteudo.asp?IDArea=1>. Acesso em: abr. 2001.

INSTITUTO BRASILEIRO DE GOVERNÇA CORPORATIVA. Código das melhores práticas. Disponível em: <http://www.ibgc.org.br/ibConteudo.asp?IDArea=230\&IDp=3 >. Acesso em: maio 2002.

ITURRIAGA, F. J. L.; SANZ, J. A. R. Ownership structure, corporate value and firm investment: a Spanish firms simultaneous equations analysis. Universidad de Valladolid Facultad de Ciencias Económicas y Empresariales, Valladolid. España, Working Paper, jul., 2002.

JAGANNATHAN, M. Internal control mechanisms and forced ceo turnover: an empirical investigation. Virginia, 1996. 83 f. Dissertation (PH.D. in Finance) - Virginia Polytechnic Institute and State University.

JENSEN, M. C. Agency costs of free cash flow, corporate finance, and takeovers. American Economic Review, v. 76, n. 2, p. 323-329, May 1986.

JENSEN, M. C. Foundations of organizational strategy. Journal Of Applied Corporate Finance, v. 7, n. 2, p. 4-19, Summer, 1994.

JENSEN, M. C. Self-interest, altruism, incentives, \& agency theory Journal Of Applied Corporate Finance, v. 7, n. 2, Summer 1994

JENSEN, M. C. The modern industrial revolution, exit, and the failure of internal control systems. Journal of Finance, v. 48 n. 3, p. 831-880, 1993.

JENSEN, M. C. Value maximization, stakeholder theory, and the corporate objective function. Business Ethics Quarterly, v. 12, n..1, Jan. 2001. 
JENSEN, M. C.; MECKLIG, W. H. Divisional performance measurement In: Foundations of organizational strategy. Cap. 12. Harvard University Press, 1998.

JENSEN, M. C.; MECKLING, W. H. A theory of the firm: governance, residual claims and organizational forms. Journal Of Financial Economics, v. 3, n. 4, p. 305-360, Oct. 1976.

JENSEN, M. C.; MURPHY, K. J. CEO incentives--it's not how much you pay but how. Harvard Business Review, n. 3, p. 138-153, May/June 1990.

JENSEN, M. C.; MURPHY, K. J. Performance pay and top management incentives. Journal of Polical Economy, v. 98, p. 225-265, 1990.

JOHN, K.; WILLIAMS, J. dividends, dilution, and taxes: a signalling equilibrium. The Journal of Finance, v. 40, n. 4. p. 1053-1070, Sept. 1985.

JOHN, K.; SENBET, L. Corporate governance and board effectiveness. Journal of Banking and Finance, Inglaterra, v. 22, p.371-403, 1998.

JUDGE, W. Q.; ZEITHAML, C. P. Institutional and strategic choice perspectives on board involvement in the strategic decision process. Academy of Management Journal, v. 31, $\mathrm{n}$. 4, 766-784, 1992

KASSAI, J. R., KASSAI, S.; NOSSA, V. A teoria do agenciamento e a contabilidade. In: $\mathbf{2 4}^{\mathbf{0}}$ ENCONTRO DA ANPAD, 2000. Anais em CD-ROM. Florianópolis (SC).

KERR, S. On the folly of rewarding A, while hoping for B. The Academy of Management Journal, v. 18, n. 4, , p. 769-783, Dec. 1975.

KLEIN, B.; CRAWFORD, R. G.; ALCHIAN, A. A. Vertical integration, appropriable rents, and the competitive contracting process. Journal of Law and Economics. V. 21, n. 2, p. 297326, Oct. 1978.

KLEIN, P. G. New institutional economics. University of Georgia, Department of Economics, Working Paper, 1999.

KMENTA, J.. Elementos de econometria: teoria econométrica básica. Tradução: Carlos Roberto Vieira de Araújo. 2. ed. São Paulo: Atlas, 1994. Tradução de: Elements of econometrics.

KOLE, S. R.; SIMON, W. E. The complexity of compensation contracts. Journal of. Financial Economics, v. 43, n. 1, p. 79-104, jan. 1997.

LA PORTA, R.; LOPES-De-SILANEZ, F.; SHLEIFER, A.; VISHNY, R. Legal determinants of external finance. The Journal of Finance, v. 52, n. 3, p. 1131-1150, July 1997.

LA PORTA, R.; LOPEZ-DE-SILANES, F., SHLEIFER, A.; VISHNY, R. W. Law and Finance. Journal of Political Economy, v.106, n.6, p. 1113-1155, 1998.

LA PORTA, R.; LOPEZ-DE-SILANES, F.; SHLEIFER, A.; VISHNY, R., 1999, Corporate ownership around the world. Journal of Finance, v. 54, n. 2. p. 717-738, 1998.

LA PORTA, R.; LOPEZ-De-SILANES, F., SHLEIFER, a; VISHNY, R.. Investor protection and corporate governance. Journal Of Financial Economics, v. 58, n. 1-2, p. 3-27, Jan. 2000 .

LANGLOIS, R. N. Transaction costs, production costs, and the passage of time. The University of Connecticut, Department of Economics, Working Paper, Aug. 1995. 
LAWRENCE, J.; STAPLEDON, G. .P. Is board composition important? a study of listed Australian companies. University of Melbourne, Austrália. Working Paper, 1999.

LEAL, R. P. C.; FERREIRA, V. A. de C.. SILVA, A. L. C. da. (Organizadores) Governança Corporativa no brasil. Rio de Janeiro: e-papers, 2002.

LEE, C. F.; CHANG, Hui-shyong. Using pooled time-series and cross-section data to test the firm an time effects in financial analysis. The Journal of Financial and Quantitative Analysis. v. 12, n. 3, p. 457-471, Sept. 1977.

LEE, D. E.; TOMPKINS, J. G. A modified version of the Lewellen and Badrinath measure of Tobin's Q. Financial Management, v. 28, n. 1, p. 20-31, Apr. 2000.

LOPES, A. B. A relevância da informação contábil para o mercado de capitais: o modelo de Ohlson aplicado à BOVESPA. São Paulo, 2001. 307 f. Tese (Doutorado em Controladoria e Contabilidade) - Faculdade de Economia, Administração e Contabilidade, Universidade de São Paulo.

LOPES, A.B. The value relevance of brazilian accounting numbers: an empirical investigation. In: ENANPAD 2002. Anais em CD-ROM. Salvador (BA). 22 a 25 set. 2002.

MADDALA, G. S. Limited dependent variable: models using panel data. The Journal of Human Resources, v. 22, n. 3, p. 307-338, Summer, 1987.

MALLETTE, P.; FOWLER, K. L. Effects of board composition and stock ownership on the adoption of poison pills. Academy of Management Journal, v. 35, n. 5, p. 1010-1035, 1992.

MANNE, H. Mergers and the market for corporate control. Journal of Political Economy, v. 73, p. 110-120, 1965.

MARQUES, L. D.. Modelos Dinâmicos com Dados em Painel: revisão de literatura. out. 2000. Disponível em: www.fep.up.pt/investigacao/workingpapers/wp100.PDF. Acesso em: set. 2002.

MARSHAL, A. The principles of economics. 1890. Disponível em: <http://www.socsci.mcmaster.ca/ econ/ugcm/31l3/marshall/prin/>. Acesso em: abr. 2002.

MARTINS, E.. Avaliação de empresas: da mensuração contábil à econômica. São Paulo: Editora Atlas, 2001.

MARTINS, G. de A. Manual para elaboração de monografias e dissertações. 2 ed.. São Paulo: Editora Atlas, 1994.

MARTINS, G. de A. Divulgação de trabalho: considerações sobre os doze anos do Caderno de Estudos. Revista Contabilidade \& Finanças - USP, n. 30, set./dez., 2002.

MAS-COLELl, A.; WHInStON, M. D.; GREEN, J. R. Microeconomic Theory. New York: Oxford University Press, 1995.

MATHIESEN, H. Managerial ownership and financial performance. Denmark, 2002. 328 f. Thesis (PH.D.) Department of International Economics and Management, Copenhagen Business School.

MCCONOMY, B.; BUJAKI, M. Corporate governance: enhancing shareholder value. Management Trends, Oct. 2000. 
MELO, A. A. O.; CUNHA , G. R.. A influência da estrutura de propriedade no retorno de mercado das empresas. In: Primeiro Encontro Brasileiro de Finanças. jul. 2001.

MÉNDEZ, C. F.; ANSÓN, S. G. Does ownership structure affect firm performance? evidence from a continental-type governance system.University of Oviedo, Fac. de CC. Económicas y Empresariales, Oviedo Asturias. Working Paper, June. 2002.

MITTON, T.. A cross-firm analysis of the impact of corporate governance on the East Asian financial crisis. Journal of Financial Economics, May 2001.

MONKS, R. A. G.; MINOW, N. Corporate Governance. 2. ed. Oxford: Blackwell Publishers Ltd, 2001.

MORCK, R.; SHLEIFER, A., VISHNY, R.. Management ownership and market valuation: an empirical analysis. Journal of Financial Economics. v. 20, p. 293-315, 1988.

MURPHY, K. J. Executive compensation. University of Southern California, Apr. 1998.

MURPHY, K. J. Performance standards in incentive contracts. University of Southern California, Working Paper, Oct. 1999.

NEW YORK STOCK EXCHANGE. Corporate Accountability and Listing Standards Committee. <Disponível em: http://www.nyse.com/pdfs/corp_govreport.pdf>. Acesso em: june 2002.

NICITA, A.. Endogenous outside options, incomplete contracts, and the nature of the firm. University of Siena and Italian Competition Authority, Working Paper, Mar. 1999.

NODOUSHANI, O.; NODOUSHANI, P. A. The debate on corporate governance: an historical analysis of Berle and Means contributions. The Journal of Behavioral and Applied Management, v. 1, n. 1, p. 55-67, Summer/Fall, 1999.

OHLSON, J. A.; BUCKMAN, A. Gregory.Toward a theory of financial accounting. Papers and Proceedings of the Thirty- Eighth Annual Meeting of the American Economic Association, Atlanta, Georgia, Dec. 28-30, 1979. The Journal of Finance, v. 35, n. 2, p. 537547, May 1980.

OTTOSSON, E.; WEISSENRIEDER, F.. CVA - Cash Value Added - a new method for measuring financial performance. Department of Economics, Gothenburg University. Göteborg. Sweden. Study n. 1996:1.

PADILLA, A. Property economics of agency problems. Proceedings of the Austrian Scholars Conference 8, 2001, Auburn, AL. Mar. 15-16. Disponível em: <http://www.mises.org/journals/scholar/Padilla5.pdf> Acesso em: set. 2002.

PATTERSON, J. The Patterson report: corporate governance and corporate performance research. Disponível em: <http://www.thecorporatelibrary.com/study/ patterson.asp> Acesso em: maio 2002.

PETRA, S. T. The effects of governance strucuture and ownership strucuture on the informativeness of earnings. New Jersey, Jan. 2002. 129 f. Dissertation (PH.D.) - Graduate School-Newark Rutgers, The State University of New Jersey.

PFEFFER, J. Size and composition of corporate boards of directors: the organization and its environment. Administrative Science Quarterly, v. 15, 1972.

PINDYCK, R. S.; RUBINFELD, D. L. Microeconomia. Tradução: Pedro Catunda. 2. ed. São 
Paulo: Makron Books, 1994. Tradução de: Microeconomic, second edition.

PINTO, W. J.; SILVA, O. M. Econometric views: guia do usuário. Disponível em: www.ufv.br/dee/ApostilaEviews.pdf. Acesso em: jan. 2003.

PODESTA, F. Recent developments in quantitative comparative methodology the case of pooled time series cross-section analysis. McDonough School of Business, Georgetown University, Working Paper, Nov. 2000.

PRAAG, M. van.; COOLS, K. Performance measure selection: aligning the principal's objective and the agent's effort. 4th Annual EUNIP Conference, Tilburg University, 7-9 Dec. 2000.

QUANTITATIVE MICRO SOFTWARE. Eviews. Versão 3.0. Copywrite 1994-1998.

RADNER, R. Hierarchy: the economics of managing. Journal of Economic Literature, v. 30, n 3, p. 1382-1415, Sept. 1992.

RADNER, R. Bounded rationality, indeterminacy, and the theory of the firm. The Economic Journal, v. 106, n. 438, p. 1360-1373, Sept. 1996.

RECHNER, P. L.; DALTON, D. R..CEO duality and organizational performance: a longitudinal analysis. Strategic Management Journal, v. 12, n. 2, p. 155-160, Feb. 1991.

REED, H. Corporate Governance, Board Structure and Accountability. ESRC Centre for Business Research, University of Cambridge, Working Paper, May 2000.

RHOADES, D. L.; RECHNER, P. L.; SUNDARAMURTHY, C. Board composition and financial performance: a meta-analysis of the influence of outside directors. Journal of Managerial Issues, Pittsburg, v. 12, n. 1, p. 76-91, Spring 2000.

RIBEIRO NETO, R. M.; FAMA, R. As perspectivas para o mercado brasileiro: a governança tem valor? porque migrar para o novo mercado. In: Primeiro Encontro Brasileiro de Finanças, jul. 2001.

ROMANO, R. Less is more: making institutional investor activism a valuable mechanism of corporate governance. Yale Journal on Regulation, New Haven, v. 18, n. 2, p. 174-252, Summer, 2001.

ROSS, S. A. The economic theory of agency: the principal's problem. Papers and Proceedings of the Eighty-fifth Annual Meeting of the American Economic Association. The American Economic Review, v. 63, n. 2, May 1973.

SANTOS et al. Manual para elaboração de citação e nota de rodapé: padrão AEUDF. Disponível em: <http://www.aeudf.br/portal/>. Acesso em: abr. 2003.

SANTOS et al. Manual para elaboração de referências: padrão AEUDF. Disponível em: <http://www.aeudf.br/portal/>. Acesso em: abr. 2003.

SAS INSTITUTE INC. Enterprise guide®. Version 2, 2002.

SCHMITZ, P. W. The hold-up problem and incomplete contracts: a survey of recent topics in contract theory. Bulletin Of Economic Research, v. 53, n. 1, Jan. 2001.

SCHNORRENBERGER A.; PROCIANOY, J. L. A Influência da Estrutura de Controle nas Decisões de Estrutura de Capital das Companhias Brasileiras. In: II Encontro Brasileiro de Finanças, Rio de Janeiro, 22 e 23 jul. 2002 
SHLEIFER, A.; VISHNY, R. A survey of corporate governance. Journal of Finance, v. 52, p. 737-783, 1997.

SHLEIFER, A.; VISHNY, R. W.. Large Shareholders and Corporate Control. The Journal of Political Economy, v. 94, n. 3, Part 1. p. 461-488, June 1986.

SIFFERT Filho, N.. Corporate Governance: international standards and empirical evidence in Brazil during the 1990s. Revista BNDES, n. 10, dez. 1998.

SILVEIRA, A. Di M. da Governança corporativa, desempenho e valor da empresa no Brasil. São Paulo, 2002. 138 f. Dissertação (Mestrado em Administração) - Universidade de São Paulo.

SIMON, H. Human nature in politics: a dialogue of psychology with political science. Amercian Political Science Review, v. 79, p. 293-304, 1985

SLOAN, R. Financial accounting and corporate governance: a discussion. Journal of Accounting and Economics, v.32, p. 335-347, 2001.

SMITH, A. An inquiry into the nature and causes of the wealth of nations. Edinburgh: 1776. Disponível em: http://www.adamsmith.org/smith/won-intro.htm. Acesso em: 11 set. 2002.

SPENCE, M. Job market signaling. The Quarterly Journal of Economics, v. 87, n. 3, 355374, Aug. 1973.

SPSS Inc. SPSS for Windows. Release 11.0.0. Chicago, IL. c1989-2001. Structure. Oxford University Press.

SROUR, G. Práticas diferenciadas de Governança Corporativa: um estudo sobre a conduta e a performance das firmas brasileiras. In: II Encontro Brasileiro de Finanças, Rio de Janeiro, 22 e 23 jul. 2002.

STERN STEWART \& Co. Learn how Stern Stewart's EVA helps companies create more wealth. Disponível em: <http://www.sternstewart.com>. Acesso em: jul. 2001.

STUDENMUND, A. H. Using econometrics: a practical guide. 4. ed. USA: Addison Wesley Longman, 2000.

TEXAS UNIVERSITY. Transformations. Disponível em: <http://www.utexas.edu/ courses/schwab/w388r7/Tutorials/Further_Look_at_Transformations_doc_html/Contents_A_ Further_Look_at_Transformations.html>. Acesso em: 18 ago. 2002.

TIROLE, J. Corporate Governance. Econometrica, v. 69, n. 1, p. 1-35, Jan. 2001.

TURNBULL, S.Corporate governance: theories, challenges and paradigms. Revue Internationale, v. 1, n. 1, 2000.

TURNBULL, S. Grounding the theory of a firm in the natural sciences. Society for the Advancement of Socio-Economics, 13th Annual Meeting on Socio-Economics, University of Amsterdam, Amsterdam, The Netherlands, June 28/July 12001.

UNIVERSIDADE ESTADUAL DE CAMPINAS. Definição operacional. Diponível em: <http://www.ime.unicamp.br/ hildete/oper.pdf>. Acesso em: abr. 2001.

UNIVERSIDADE FEDERAL DO PARANÁ, Sistema de Bibliotecas. Normas para apresentação de documentos científicos. Curitiba: Ed. da UFPR, 2002. 
VAFEAS, N. Board meeting frequency and firm performance. Journal of Financial Economics, v. 53, p.113-142, 1999.

VIVES, X. Corporate governance: theoretical and empirical perspectives. Cambridge University Press, 2000. 248p.

VOIGT, S.; ENGERER, H. Institutions and transition - possible policy implications of the new institutional economics. University of Kassel - Department of Economics and DIW Berlin, German Institute for Economic Research, Working Papers, Dec. 2001.

WATTS, R. L.; ZIMMERMAN, J. L. Positive accounting theory. New Jersey: Prentice Hall, 1986.

WEIGAND, J.; LEHMANN, E. Does ownership structure matter? governance structures and the market for corporate control in germany. July 1999. Disponível em: <www.whukoblenz.de/banking/sgf/Papers00/ lehmann.pdf. Acesso em: 06 set. 2002.

WEINER, N.; MAHONEY, T. A. A model of corporate performance as a function of environmental, organizational, and leadership influences. The Academy of management journal, v. 24, n. 3, p. 453-470, Sept., 1981.

WEISSENRIEDER, F. .Value based management: economic value added or cash value added? Department of Economics, Gothenburg University. Göteborg, Sweden, Working paper, Dec. 1997.

WERNERFELT, B.; MONTGOMERY, C. Tobin's Q and the importance of focus in firm performance. American Economic Review, v.78, p. 246-251, 1988.

WILLIAMSON, O. E. The economics of organization: the transaction cost approach. American Journal of Sociology, v. 87, p. 548-77, Nov. 1981.

WILLIAMSON, O. E. Corporate finance and corporate governance. Papers and Proceedings of the Forty-Seventh Annual Meeting of the American Finance Association. The Journal of finance, Chicago, Illinois, v. 43, n. 3, p. 567-591, 1987.

WILLIAMSON, O. E. Markets and hierarchies: some elementary considerations. Papers and Proceedings of the Eighty-fifth Annual Meeting of the American Finance Association. The American Economic Review, v. 63. n. 2, p. 316-325, May 1973.

WILLIAMSON, O. E. Markets and hierarchies: some elementary considerations. Papers and Proceedings of the Eighty-fifth Annual Meeting of the American Economic Association. The American Economic Review, v. 63, n. 2, p. 316-325, May 1973.

WILlIAMSON, O. E. The Economic Institutions of Capitalism. New York: Free Press, 1987.

WILLIAMSON, O. E. The theory of the firm as governance structure: from choice to contract. University of California Berkeley. Working Paper, Jan. 2002.

WILLIAMSON, O. E. The vertical integration of production; market failure considerations. Papers and Proceedings of the Eighty-Third Annual Meeting of the American Economic Association. The American Economic Review, v. 61, n. 2, p. 112-123, May 1971

WILLIAMSON, O. E. Why law, economics, and organization? UC Berkeley School of Law, Public Law and Legal Theory, Working Paper n.. 37, 2000.

WILLIAMSON, O. E.The institutions of governance. Papers and proceedings of the Hundred 
and Tenth Annual Meeting of the Anmerican Economic Association. The American Economic Review, v. 88, issue 2, p. 75-79, May 1998.

WILLIAMSON, O. E.The modern corporation: origins, evolution and attributes. Journal of Economic Literature, v. 19, n. 4, p. 1537-1568, Dec. 1981.

WOIDTKE, T. Agents watching agents? evidence from pension fund ownership and firm value. Journal of Financial Economics, v. 63, n. 1, p. 99-131, 2002.

WOOLDRIDGE, J. M. Econometric Analysis of cross section and panel data. USA: The MIT Press, 2002.

WRIGHT, P.; KROLL, M. J.; PARNELL, J. Administração estratégica: conceitos. Tradução: Celso A. Rimoli; Lenita R. Esteves. São Paulo: Atlas, 2000. Tradução de: Strategic managemente: concepts.

ZINGALES, L. Corporate governance. Harvard Business School. National Bureau of Economic Research (NBER), Working Paper n. W6309, Dec. 1997. 
APÊNDICE 1 - DADOS UTILIZADOS NO ESTUDO 


\begin{tabular}{|c|c|c|c|c|c|c|c|}
\hline Empresas & Ano & MVA & P_VPA & TOBIN'S Q & RENT_ATI & RENT_PL & OWNER_1 \\
\hline AES Tiete PN & 2000 & 677.674 & 1,50 & 1,06 & 3,05 & 3,05 & 61,65 \\
\hline AES Tiete PN & 2001 & 801.158 & 2,20 & 1,11 & 3,68 & 11,02 & 61,65 \\
\hline Acesita PN & 1997 & -1.015 .617 & 0,10 & 0,51 & $-1,18$ & $-3,82$ & 23,94 \\
\hline Acesita PN & 1998 & -879.422 & 0,30 & 0,46 & $-14,24$ & $-52,80$ & 38,94 \\
\hline Acesita PN & 1999 & -278.465 & 0,60 & 0,54 & $-10,00$ & $-34,79$ & 38,94 \\
\hline Acesita PN & 2000 & -692.234 & 0,60 & 0,50 & $-0,25$ & $-0,25$ & 38,94 \\
\hline Acesita PN & 2001 & -735.080 & 0,40 & 0,49 & $-6,25$ & $-26,12$ & 38,94 \\
\hline Ambev PN & 2000 & 16.557 .283 & 5,90 & 2,35 & 8,67 & 8,67 & 22,67 \\
\hline Ambev PN & 2001 & 15.626 .081 & 5,60 & 2,11 & 9,08 & 25,50 & 22,50 \\
\hline Aracruz PNB & 1997 & -645.003 & 0,70 & 0,80 & $-2,08$ & $-3,46$ & 28,00 \\
\hline Aracruz PNB & 1998 & -1.315 .141 & 0,40 & 0,64 & $-1,78$ & $-3,11$ & 28,00 \\
\hline Aracruz PNB & 1999 & 2.551 .607 & 2,20 & 1,45 & 1,63 & 3,14 & 28,00 \\
\hline Aracruz PNB & 2000 & 912.972 & 1,30 & 1,05 & 11,56 & 11,56 & 28,00 \\
\hline Aracruz PNB & 2001 & 1.807 .429 & 1,70 & 1,22 & 5,35 & 8,75 & 28,00 \\
\hline Bahia Sul PNA & 1999 & -159.213 & 0,80 & 0,80 & 0,95 & 1,86 & 50,00 \\
\hline Bahia Sul PNA & 2000 & -464.323 & 0,50 & 0,62 & 9,16 & 9,16 & 100,00 \\
\hline Bahia Sul PNA & 2001 & -620.582 & 0,50 & 0,60 & 4,44 & 7,61 & 100,00 \\
\hline Bardella PN & 1997 & -21.861 & 0,90 & 0,13 & 0,52 & 1,13 & 36,96 \\
\hline Bardella PN & 1998 & -148.618 & 0,30 & 0,05 & 4,11 & 8,91 & 37,00 \\
\hline Bardella PN & 1999 & -124.425 & 0,40 & 0,33 & 4,39 & 8,50 & 45,00 \\
\hline Bardella PN & 2000 & -138.686 & 0,40 & 0,28 & 5,73 & 5,73 & 45,00 \\
\hline Bardella PN & 2001 & -161.985 & 0,40 & 0,25 & 1,52 & 2,39 & 45,01 \\
\hline Belgo Mineira ON & 1998 & -785.210 & 0,40 & 0,43 & 1,90 & 5,07 & 50,59 \\
\hline Belgo Mineira ON & 1999 & -761.229 & 0,50 & 0,52 & $-1,03$ & $-3,01$ & 59,26 \\
\hline Belgo Mineira ON & 2000 & -648.988 & 0,50 & 0,37 & 11,03 & 11,03 & 59,26 \\
\hline Belgo Mineira ON & 2001 & -1.001 .451 & 0,40 & 0,41 & 4,89 & 10,29 & 59,26 \\
\hline Bombril PN & 1997 & -27.947 & 0,40 & 0,42 & 2,93 & 5,84 & 100,00 \\
\hline Bombril PN & 1998 & -472.492 & 0,30 & 0,37 & 1,07 & 3,31 & 75,00 \\
\hline Bombril PN & 1999 & -54.037 & 0,70 & 0,65 & 16,95 & 30,86 & 100,00 \\
\hline Bombril PN & 2000 & -66.306 & 0,80 & 0,72 & 6,80 & 6,80 & 100,00 \\
\hline Bombril PN & 2001 & -511.029 & 0,30 & 0,35 & 11,13 & 19,07 & 100,00 \\
\hline Brasil T Par PN & 1999 & 5.761 .858 & 1,70 & 1,08 & 2,81 & 4,26 & 51,79 \\
\hline Brasil T Par PN & 2000 & 1.468 .082 & 1,30 & 0,65 & 4,30 & 4,30 & 52,26 \\
\hline Brasil T Par PN & 2001 & 230.521 & 1,10 & 0,61 & 1,84 & 4,27 & 53,45 \\
\hline Brasil Telecom PN & 1999 & 199.037 & 1,20 & 0,95 & $-1,77$ & $-2,54$ & 81,98 \\
\hline Brasil Telecom PN & 2000 & 6.686 .692 & 1,20 & 0,86 & 17,46 & 17,46 & 98,66 \\
\hline Brasil Telecom PN & 2001 & -115.941 & 1,00 & 0,76 & 2,25 & 3,93 & 97,71 \\
\hline CRT Celular PNA & 2000 & 1.436 .733 & 2,90 & 1,64 & 5,51 & 5,51 & 20,30 \\
\hline CRT Celular PNA & 2001 & 804.752 & 2,00 & 1,24 & 7,69 & 15,97 & 18,63 \\
\hline Caemi Metal PN & 2000 & 188.849 & 1,10 & 0,70 & 3,84 & 3,84 & 50,00 \\
\hline Caemi Metal PN & 2001 & 269.141 & 1,20 & 0,74 & 3,51 & 10,40 & 50,00 \\
\hline Celesc PNB & 1997 & -379.456 & 0,70 & 0,56 & 2,59 & 3,43 & 50,18 \\
\hline Celesc PNB & 1998 & -1.080 .788 & 0,30 & 0,25 & $-2,72$ & $-3,75$ & 50,18 \\
\hline Celesc PNB & 1999 & -674.659 & 0,60 & 0,37 & 0,06 & 0,11 & 50,18 \\
\hline Celesc PNB & 2000 & -698.373 & 0,40 & 0,25 & 0,17 & 0,17 & 50,18 \\
\hline Celesc PNB & 2001 & -791.327 & 0,30 & 0,20 & 1,78 & 3,95 & 50,18 \\
\hline Cemig PN & 1997 & -2.452 .924 & 0,80 & 0,64 & 1,79 & 2,51 & 50,96 \\
\hline Cemig PN & 1998 & -4.294 .370 & 0,50 & 0,42 & 4,31 & 6,07 & 50,96 \\
\hline Cemig PN & 1999 & -1.572 .971 & 0,80 & 0,68 & 0,30 & 0,42 & 50,96 \\
\hline Cemig PN & 2000 & -3.105 .197 & 0,60 & 0,49 & 3,62 & 3,62 & 50,96 \\
\hline
\end{tabular}




\begin{tabular}{|c|c|c|c|c|c|c|c|}
\hline Empresas & Ano & MVA & P_VPA & TOBIN'S Q & RENT_ATI & RENT_PL & OWNER_1 \\
\hline Cemig PN & 2001 & -2.570 .550 & 0,80 & 0,52 & 4,00 & 6,11 & 50,96 \\
\hline Cesp PN & 1998 & -11.922 .577 & 0,20 & 0,28 & 3,22 & 6,00 & 40,67 \\
\hline Cesp PN & 2000 & -9.238 .721 & 0,20 & 0,43 & $-2,09$ & $-2,09$ & 60,52 \\
\hline Cesp PN & 2001 & -9.287 .167 & 0,10 & 0,47 & $-4,16$ & $-7,61$ & 60,52 \\
\hline Cim Itau PN & 1997 & -69.112 & 0,90 & 0,48 & 9,63 & 14,32 & 70,90 \\
\hline Cim Itau PN & 1998 & -279.034 & 0,50 & 0,23 & 6,50 & 9,79 & 70,92 \\
\hline Cim Itau PN & 1999 & -50.920 & 0,90 & 0,66 & 7,90 & 12,43 & 70,91 \\
\hline Cim Itau PN & 2000 & 42.348 & 0,90 & 0,67 & 17,18 & 17,18 & 98,53 \\
\hline Cim Itau PN & 2001 & 159.246 & 0,90 & 0,73 & 23,87 & 34,18 & 98,53 \\
\hline Coelce PNA & 1998 & 27.588 & 1,00 & 0,57 & 3,22 & 6,31 & 82,69 \\
\hline Coelce PNA & 1999 & 355.652 & 0,60 & 0,53 & 7,77 & 16,78 & 91,66 \\
\hline Coelce PNA & 2000 & -286.722 & 0,80 & 0,61 & 4,74 & 4,74 & 91,66 \\
\hline Coelce PNA & 2001 & -508.008 & 0,60 & 0,48 & 6,12 & 9,44 & 91,66 \\
\hline Comgas PNA & 1997 & 561.455 & 2,20 & 1,53 & 1,65 & 3,16 & 75,08 \\
\hline Comgas PNA & 1998 & 239.589 & 1,50 & 1,13 & $-0,24$ & $-0,37$ & 75,08 \\
\hline Comgas PNA & 1999 & 166.537 & 2,10 & 1,24 & $-18,20$ & $-27,77$ & 76,10 \\
\hline Comgas PNA & 2000 & 1.091 .930 & 1,60 & 1,20 & 7,41 & 7,41 & 76,10 \\
\hline Comgas PNA & 2001 & 255.217 & 1,30 & 0,88 & 4,88 & 7,64 & 76,10 \\
\hline Confab PN & 1997 & -5.526 & 0,90 & 0,33 & 4,67 & 7,93 & 64,03 \\
\hline Confab PN & 1998 & -138.455 & 0,40 & 0,13 & 10,42 & 24,17 & 99,22 \\
\hline Confab PN & 1999 & -95.562 & 0,60 & 0,40 & 6,42 & 12,79 & 99,22 \\
\hline Confab PN & 2000 & -183.113 & 0,40 & 0,31 & 0,05 & 0,05 & 99,00 \\
\hline Confab PN & 2001 & -62.624 & 0,70 & 0,37 & 14,39 & 24,60 & 99,00 \\
\hline Copel PNB & 1997 & 89.457 & 0,90 & 0,62 & 2,27 & 3,50 & 60,00 \\
\hline Copel PNB & 1998 & -2.479 .642 & 0,50 & 0,46 & 5,42 & 8,30 & 58,63 \\
\hline Copel PNB & 2000 & -303.796 & 0,90 & 0,69 & 5,59 & 5,59 & 58,63 \\
\hline Copel PNB & 2001 & -300.744 & 0,90 & 0,67 & 5,97 & 9,70 & 58,63 \\
\hline Copene PNA & 1997 & -2.180 .078 & 0,20 & 0,31 & $-0,73$ & $-1,64$ & 58,41 \\
\hline Copene PNA & 1998 & -2.526 .291 & 0,10 & 0,35 & $-0,11$ & $-0,16$ & 58,41 \\
\hline Copene PNA & 1999 & -877.179 & 0,50 & 0,65 & 5,28 & 8,51 & 58,41 \\
\hline Copene PNA & 2000 & -1.009 .826 & 0,50 & 0,60 & 6,41 & 6,41 & 58,41 \\
\hline Copene PNA & 2001 & -1.437 .008 & 0,40 & 0,61 & $-0,75$ & $-1,25$ & 58,41 \\
\hline Cosipa PN & 2000 & -698.569 & 0,20 & 0,46 & 0,79 & 0,79 & 94,57 \\
\hline Cosipa PN & 2001 & 1.054 .206 & 1,20 & 0,90 & $-4,38$ & $-23,65$ & 94,57 \\
\hline Coteminas PN & 2000 & -168.657 & 0,70 & 0,50 & 5,62 & 5,62 & 51,36 \\
\hline Coteminas PN & 2001 & -149.009 & 0,70 & 0,54 & 6,35 & 9,35 & 51,36 \\
\hline Duratex PN & 1997 & -184.950 & 0,70 & 0,41 & 1,30 & 2,03 & 59,99 \\
\hline Duratex PN & 1998 & -325.117 & 0,50 & 0,33 & 3,93 & 6,96 & 59,99 \\
\hline Duratex PN & 1999 & -149.815 & 0,80 & 0,55 & 0,88 & 1,60 & 60,09 \\
\hline Duratex PN & 2000 & 55.407 & 0,80 & 0,46 & 6,00 & 6,00 & 62,41 \\
\hline Duratex PN & 2001 & -272.464 & 0,70 & 0,45 & 3,59 & 6,13 & 62,41 \\
\hline EMAE PN & 2000 & -701.673 & 0,20 & 0,16 & 1,39 & 1,39 & 97,44 \\
\hline EMAE PN & 2001 & -559.973 & 0,40 & 0,29 & 1,58 & 1,90 & 97,44 \\
\hline Eletrobras PNB & 1997 & -29.006 .940 & 0,50 & 0,39 & 0,32 & 0,50 & 53,61 \\
\hline Eletrobras PNB & 1998 & -49.176 .817 & 0,20 & 0,27 & 2,05 & 3,23 & 58,41 \\
\hline Eletrobras PNB & 1999 & -38.284 .277 & 0,40 & 0,37 & 0,66 & 0,97 & 58,41 \\
\hline Eletrobras PNB & 2000 & -41.536 .586 & 0,30 & 0,35 & 2,89 & 2,89 & 58,41 \\
\hline Eletrobras PNB & 2001 & -46.821 .231 & 0,20 & 0,37 & 3,57 & 5,23 & 58,41 \\
\hline Eletropaulo Metro & 1999 & 2.571 .216 & 1,80 & 0,83 & 5,40 & 17,40 & 30,97 \\
\hline Eletropaulo Metro & 2000 & 987.199 & 1,50 & 0,73 & 2,95 & 2,95 & 77,81 \\
\hline Eletropaulo Metro & 2001 & 705.406 & 1,10 & 0,59 & 6,58 & 22,18 & 77,81 \\
\hline Embraer ON & 1999 & 3.913 .087 & 6,20 & 1,47 & 20,05 & 98,63 & 20,00 \\
\hline Embraer ON & 2000 & 6.014 .007 & 4,40 & 1,07 & 18,64 & 18,64 & 20,00 \\
\hline
\end{tabular}




\begin{tabular}{|c|c|c|c|c|c|c|c|}
\hline Empresas & Ano & MVA & P_VPA & TOBIN'S Q & RENT_ATI & RENT_PL & OWNER_1 \\
\hline Embraer ON & 2001 & 6.246 .033 & 3,20 & 1,01 & 21,59 & 71,55 & 20,00 \\
\hline Embratel Part PN & 1999 & 9.887 .637 & 2,70 & 1,71 & 5,08 & 7,47 & 51,79 \\
\hline Embratel Part PN & 2000 & 4.015 .823 & 1,60 & 0,98 & 5,98 & 5,98 & 49,90 \\
\hline Embratel Part PN & 2001 & -2.771 .620 & 0,60 & 0,51 & $-4,71$ & $-9,10$ & 49,90 \\
\hline F Cataguazes PNA & 1998 & -235.699 & 0,40 & 0,61 & $-1,23$ & $-2,94$ & 51,00 \\
\hline F Cataguazes PNA & 1999 & -175.244 & 0,60 & 0,68 & $-3,15$ & $-8,59$ & 51,00 \\
\hline F Cataguazes PNA & 2000 & -163.666 & 0,60 & 0,46 & 2,65 & 2,65 & 51,00 \\
\hline F Cataguazes PNA & 2001 & -161.059 & 0,60 & 0,47 & $-0,03$ & $-0,20$ & 51,00 \\
\hline Fosfertil PN & 1998 & -86.590 & 0,80 & 0,55 & 6,13 & 15,88 & 69,88 \\
\hline Fosfertil PN & 1999 & 439.916 & 1,90 & 0,81 & 12,13 & 29,66 & 69,88 \\
\hline Fosfertil PN & 2000 & 91.546 & 1,10 & 0,57 & 7,78 & 7,78 & 81,54 \\
\hline Fosfertil PN & 2001 & 158.714 & 1,20 & 0,69 & 9,87 & 27,96 & 81,54 \\
\hline Gerasul - Tracteb & 2000 & -437.188 & 0,70 & 0,71 & 3,86 & 3,86 & 80,42 \\
\hline Gerasul - Tracteb & 2001 & 92.062 & 0,90 & 0,73 & 11,24 & 23,94 & 80,42 \\
\hline Gerdau Met PN & 1997 & -118.790 & 0,40 & 0,28 & 2,43 & 14,21 & 30,74 \\
\hline Gerdau Met PN & 1998 & -590.212 & 0,20 & 0,27 & 4,17 & 15,33 & 30,59 \\
\hline Gerdau Met PN & 1999 & 18.096 & 0,90 & 0,60 & 6,01 & 23,33 & 30,59 \\
\hline Gerdau Met PN & 2000 & -317.302 & 0,60 & 0,55 & 3,37 & 3,37 & 32,30 \\
\hline Gerdau Met PN & 2001 & -493.724 & 0,50 & 0,49 & 3,62 & 21,87 & 32,30 \\
\hline Gerdau ON & 1997 & -277.450 & 0,60 & 0,42 & 5,29 & 9,16 & 82,71 \\
\hline Gerdau ON & 1998 & -1.072 .307 & 0,30 & 0,29 & 6,73 & 11,45 & 82,71 \\
\hline Gerdau ON & 1999 & 60.354 & 0,90 & 0,75 & 10,53 & 19,46 & 82,97 \\
\hline Gerdau ON & 2000 & -662.837 & 0,60 & 0,66 & 6,18 & 6,18 & 82,98 \\
\hline Gerdau ON & 2001 & -374.562 & 0,70 & 0,63 & 6,72 & 19,62 & 82,54 \\
\hline Globo Cabo - Net & 1999 & 7.127.405 & 21,60 & 5,53 & $-36,57$ & $-173,18$ & 62,02 \\
\hline Globo Cabo - Net & 2000 & 5.601 .241 & 25,90 & 3,27 & $-24,89$ & $-24,89$ & 56,71 \\
\hline Globo Cabo - Net & 2001 & 2.047 .626 & 7,30 & 1,49 & $-31,05$ & $-304,98$ & 40,70 \\
\hline Inepar Construcoe & 1997 & 192.328 & 0,80 & 0,55 & $-6,23$ & $-17,65$ & 70,25 \\
\hline Inepar Construcoes & 1998 & -241.626 & 0,50 & 0,33 & 2,82 & 7,08 & 60,68 \\
\hline Inepar Construcoes & 1999 & -69.111 & 0,70 & 0,45 & $-6,20$ & $-39,27$ & 60,68 \\
\hline Inepar Construcoes & 2000 & -369.963 & 0,40 & 0,42 & $-13,24$ & $-13,24$ & 60,68 \\
\hline Inepar Construcoes & 2001 & -269.338 & 0,30 & 0,39 & $-8,43$ & $-35,09$ & 60,68 \\
\hline lochp-Maxion PN & 1997 & -143.988 & 0,50 & 0,54 & $-0,89$ & $-3,08$ & 74,27 \\
\hline lochp-Maxion PN & 1998 & -179.433 & 0,10 & 0,39 & $-18,55$ & $-67,99$ & 45,64 \\
\hline lochp-Maxion PN & 1999 & -39.382 & 1,10 & 0,75 & $-8,26$ & $-22,45$ & 45,64 \\
\hline lochp-Maxion PN & 2000 & -84.963 & 0,60 & 0,58 & 2,09 & 2,09 & 45,64 \\
\hline lochp-Maxion PN & 2001 & -86.089 & 0,40 & 0,30 & 3,78 & 14,77 & 45,64 \\
\hline Ipiranga Pet PN & 1997 & 225.715 & 1,10 & 0,77 & 2,22 & 3,59 & 62,87 \\
\hline Ipiranga Pet PN & 1998 & -430.781 & 0,40 & 0,30 & 16,87 & 25,26 & 62,87 \\
\hline Ipiranga Pet PN & 1999 & 113.759 & 1,10 & 0,75 & 6,92 & 10,64 & 62,87 \\
\hline Ipiranga Pet PN & 2000 & -118.349 & 0,90 & 0,64 & 2,96 & 2,96 & 62,87 \\
\hline Ipiranga Pet PN & 2001 & -327.108 & 0,70 & 0,55 & 1,50 & 2,46 & 62,87 \\
\hline Itausa PN & 1998 & -677.248 & 0,70 & 0,21 & 0,96 & 16,93 & 16,07 \\
\hline Itausa PN & 1999 & 2.827 .343 & 1,70 & 0,09 & 1,86 & 31,87 & 16,10 \\
\hline Itausa PN & 2000 & 2.261 .519 & 1,40 & 0,07 & 1,63 & 1,63 & 16,05 \\
\hline Itausa PN & 2001 & 2.422 .230 & 1,30 & 0,06 & 1,64 & 28,75 & 16,05 \\
\hline Klabin PN & 1997 & -839.658 & 0,30 & 0,50 & 0,28 & 0,61 & 57,66 \\
\hline Klabin PN & 1998 & -1.049 .073 & 0,20 & 0,43 & $-1,20$ & $-2,79$ & 57,66 \\
\hline Klabin PN & 1999 & -63.950 & 1,10 & 0,78 & $-4,19$ & $-9,83$ & 57,66 \\
\hline Klabin PN & 2000 & 324.327 & 1,10 & 0,88 & 0,43 & 0,43 & 57,67 \\
\hline Kuala PN & 1999 & -26.617 & 2,00 & 0,76 & $-29,87$ & $-70,71$ & 53,86 \\
\hline Kuala PN & 2000 & -6.724 & 1,60 & 0,63 & $-9,87$ & $-9,87$ & 53,86 \\
\hline Kuala PN & 2001 & 148 & 0,80 & 0,59 & $-0,27$ & $-2,30$ & 53,86 \\
\hline
\end{tabular}




\begin{tabular}{|c|c|c|c|c|c|c|c|}
\hline Empresas & Ano & MVA & P_VPA & TOBIN'S Q & RENT_ATI & RENT_PL & OWNER_1 \\
\hline Light ON & 2000 & 660.955 & 1,40 & 0,67 & $-1,92$ & $-1,92$ & 33,99 \\
\hline Light ON & 2001 & -467.359 & 19,90 & 0,82 & $-6,29$ & $-43,53$ & 48,40 \\
\hline Lojas Americanas & 1998 & -128.819 & 0,50 & 0,08 & 15,87 & 39,62 & 48,11 \\
\hline Lojas Americanas & 2000 & 36.462 & 1,40 & 0,33 & $-1,97$ & $-1,97$ & 48,20 \\
\hline Lojas Americanas & 2001 & 111.725 & 1,30 & 0,17 & 5,46 & 32,00 & 56,31 \\
\hline Magnesita PNA & 1997 & -175.265 & 0,30 & 0,09 & 1,74 & 2,69 & 51,00 \\
\hline Magnesita PNA & 1998 & -208.036 & 0,20 & 0,02 & 7,77 & 11,33 & 50,39 \\
\hline Magnesita PNA & 1999 & -155.869 & 0,40 & 0,08 & 9,12 & 12,82 & 50,75 \\
\hline Magnesita PNA & 2000 & -169.080 & 0,40 & 0,07 & 11,34 & 11,34 & 50,02 \\
\hline Magnesita PNA & 2001 & -214.387 & 0,40 & 0,16 & 7,92 & 11,06 & 50,02 \\
\hline PETROBRAS BR & 1998 & -806.854 & 0,30 & 0,17 & 11,56 & 19,16 & 99,86 \\
\hline PETROBRAS BR & 1999 & -157.430 & 1,00 & 0,45 & $-2,95$ & $-5,74$ & 99,86 \\
\hline PETROBRAS BR & 2000 & -63.519 & 0,80 & 0,34 & 10,12 & 10,12 & 99,86 \\
\hline PETROBRAS BR & 2001 & -15.803 & 0,90 & 0,37 & 11,25 & 25,42 & 99,86 \\
\hline Petrobras PN & 1999 & 28.226 .169 & 2,80 & 1,12 & 4,42 & 8,11 & 55,70 \\
\hline Petrobras PN & 2000 & 32.157 .718 & 2,00 & 0,83 & 17,55 & 17,55 & 55,70 \\
\hline Petrobras PN & 2001 & 30.608 .582 & 1,90 & 0,76 & 14,73 & 39,55 & 55,71 \\
\hline Plascar PN & 1997 & -107.362 & 0,30 & 0,36 & $-3,53$ & $-4,76$ & 99,99 \\
\hline Plascar PN & 1998 & -122.225 & 0,30 & 0,42 & $-4,61$ & $-6,23$ & 99,99 \\
\hline Plascar PN & 1999 & -63.755 & 0,90 & 0,77 & $-22,76$ & $-36,22$ & 99,99 \\
\hline Plascar PN & 2000 & -54.687 & 0,90 & 0,55 & $-23,60$ & $-23,60$ & 99,99 \\
\hline Plascar PN & 2001 & -28.752 & 0,50 & 0,42 & $-6,25$ & $-24,89$ & 99,99 \\
\hline Ripasa PN & 1997 & -557.478 & 0,10 & 0,31 & 2,02 & 3,03 & 97,00 \\
\hline Ripasa PN & 1998 & -581.790 & 0,00 & 0,26 & $-4,99$ & $-8,13$ & 97,00 \\
\hline Ripasa PN & 1999 & -244.962 & 0,50 & 0,50 & 8,42 & 14,24 & 98,00 \\
\hline Ripasa PN & 2000 & -249.110 & 0,50 & 0,40 & 10,39 & 10,39 & 98,00 \\
\hline Ripasa PN & 2001 & -334.484 & 0,50 & 0,42 & 10,16 & 14,14 & 97,66 \\
\hline Sabesp ON & 1997 & -792.476 & 0,90 & 0,83 & 0,86 & 1,36 & 65,91 \\
\hline Sabesp ON & 1998 & -5.790 .278 & 0,30 & 0,51 & 3,92 & 6,49 & 64,52 \\
\hline Sabesp ON & 1999 & -2.393 .003 & 0,70 & 0,77 & $-1,61$ & $-2,79$ & 85,39 \\
\hline Sabesp ON & 2000 & -3.316 .097 & 0,60 & 0,71 & 3,45 & 3,45 & 85,30 \\
\hline Sabesp ON & 2001 & -4.509 .169 & 0,50 & 0,61 & 1,42 & 2,62 & 71,55 \\
\hline Sid Nacional ON & 1998 & -2.452 .243 & 0,40 & 0,49 & 4,98 & 9,91 & 17,89 \\
\hline Sid Nacional ON & 1999 & 466.021 & 0,90 & 0,76 & 2,32 & 4,33 & 17,89 \\
\hline Sid Nacional ON & 2000 & -1.727 .969 & 0,70 & 0,60 & 14,21 & 14,21 & 46,48 \\
\hline Sid Nacional ON & 2001 & -3.085 .583 & 0,50 & 0,61 & 1,96 & 5,26 & 46,48 \\
\hline Sid Tubarao PN & 1997 & -2.286 .127 & 0,20 & 0,36 & $-0,62$ & $-0,87$ & 20,51 \\
\hline Sid Tubarao PN & 1998 & -2.843 .630 & 0,10 & 0,30 & 1,21 & 1,88 & 20,51 \\
\hline Sid Tubarao PN & 1999 & -1.597 .013 & 0,40 & 0,51 & $-7,50$ & $-11,76$ & 20,51 \\
\hline Sid Tubarao PN & 2000 & -2.662 .558 & 0,30 & 0,43 & 2,48 & 2,48 & 20,51 \\
\hline Sid Tubarao PN & 2001 & -2.653 .860 & 0,30 & 0,48 & $-1,07$ & $-1,85$ & 20,51 \\
\hline Suzano PN & 2000 & -67.510 & 0,70 & 0,42 & 14,44 & 14,44 & 99,99 \\
\hline Suzano PN & 2001 & -588.476 & 1,00 & 0,56 & 7,75 & 16,51 & 99,99 \\
\hline Tele Celular Sul & 1999 & 1.451 .307 & 3,60 & 1,92 & 3,79 & 6,35 & 51,80 \\
\hline Tele Celular Sul & 2000 & 1.158 .674 & 2,20 & 1,35 & 1,33 & 1,33 & 51,35 \\
\hline Tele Celular Sul & 2001 & 426.496 & 1,50 & 0,93 & 4,10 & 7,78 & 52,06 \\
\hline Tele Centroeste C & 2000 & 1.452 .489 & 2,80 & 1,32 & 8,78 & 8,78 & 53,80 \\
\hline Tele Centroeste C & 2001 & 1.057 .430 & 1,90 & 1,04 & 10,86 & 23,22 & 53,23 \\
\hline Tele Leste Celula & 1999 & 246.353 & 3,00 & 1,27 & $-18,09$ & $-32,85$ & 54,62 \\
\hline Tele Leste Celula & 2000 & 456.104 & 1,40 & 0,94 & $-1,42$ & $-1,42$ & 53,81 \\
\hline Tele Leste Celula & 2001 & 13.099 & 1,00 & 0,84 & 0,66 & 1,33 & 53,81 \\
\hline Tele Nordeste Cel & 1999 & 1.207.225 & 4,40 & 1,94 & 1,35 & 2,66 & 51,79 \\
\hline Tele Nordeste Cel & 2000 & 979.158 & 2,30 & 1,36 & 2,75 & 2,75 & 51,24 \\
\hline
\end{tabular}




\begin{tabular}{|c|c|c|c|c|c|c|c|}
\hline Empresas & Ano & MVA & P_VPA & TOBIN'S Q & RENT_ATI & RENT_PL & OWNER_1 \\
\hline Tele Nordeste Cel & 2001 & 503.726 & 1,70 & 0,99 & 5,29 & 11,38 & 51,24 \\
\hline Tele Norte Celula & 1999 & 329.670 & 1,50 & 0,86 & 6,59 & 13,50 & 51,79 \\
\hline Tele Norte Celula & 2000 & 82.285 & 1,70 & 0,74 & 1,74 & 1,74 & 5,40 \\
\hline Tele Norte Celula & 2001 & 90.164 & 1,40 & 0,80 & $-0,79$ & $-2,55$ & 5,40 \\
\hline Tele Sudeste Celu & 1999 & 3.569.795 & 4,90 & 2,49 & 3,15 & 4,81 & 49,97 \\
\hline Tele Sudeste Celu & 2000 & 1.777.978 & 1,70 & 1,16 & 6,18 & 6,18 & 47,15 \\
\hline Tele Sudeste Celu & 2001 & 729.081 & 1,40 & 1,02 & 6,04 & 10,04 & 51,62 \\
\hline Telemar Norte Les & 1999 & 361.811 & 0,80 & 0,68 & $-8,11$ & $-14,27$ & 95,79 \\
\hline Telemar Norte Les & 2000 & 87.016 & 1,00 & 0,79 & $-0,45$ & $-0,45$ & 95,79 \\
\hline Telemar Norte Les & 2001 & 9.626 .365 & 1,20 & 0,80 & 0,85 & 1,31 & 97,24 \\
\hline Telemar PN & 2000 & 4.216.371 & 1,50 & 0,84 & 3,93 & 3,93 & 52,26 \\
\hline Telemar PN & 2001 & 3.474 .685 & 1,40 & 0,80 & 0,72 & 1,36 & 52,96 \\
\hline Telemig Celul Par & 1999 & 907.155 & 1,30 & 0,90 & 2,00 & 3,74 & 5,39 \\
\hline Telemig Celul Par & 2000 & 934.828 & 3,00 & 1,55 & 2,48 & 2,48 & 5,40 \\
\hline Telemig Celul Par & 2001 & 760.901 & 2,00 & 1,01 & 6,40 & 13,86 & 5,40 \\
\hline Telemig Celular P & 1999 & 383.725 & 2,00 & 1,12 & 0,94 & 1,68 & 89,18 \\
\hline Telemig Celular P & 2000 & 696.785 & 2,60 & 1,25 & 6,60 & 6,60 & 89,18 \\
\hline Telemig Celular P & 2001 & 422.207 & 1,70 & 0,89 & 10,21 & 26,71 & 89,18 \\
\hline Telepar Celular P & 1999 & 164.565 & 2,10 & 1,08 & $-11,29$ & $-21,89$ & 81,98 \\
\hline Telepar Celular P & 2000 & 228.712 & 1,30 & 0,79 & $-5,63$ & $-5,63$ & 87,43 \\
\hline Telepar Celular P & 2001 & -20.873 & 1,00 & 0,77 & $-2,10$ & $-5,54$ & 87,43 \\
\hline Telesp Cel Part P & 2000 & 7.091.574 & 2,40 & 1,67 & 2,79 & 2,79 & 40,22 \\
\hline Telesp Cel Part P & 2001 & 39.001 & 1,40 & 0,93 & $-17,95$ & $-28,87$ & 40,22 \\
\hline Telesp Operac PN & 1999 & 9.134 .525 & 1,50 & 1,20 & 5,04 & 6,55 & 46,20 \\
\hline Telesp Operac PN & 2000 & -952.784 & 0,90 & 0,73 & 8,23 & 8,23 & 46,20 \\
\hline Telesp Operac PN & 2001 & 71.805 & 1,00 & 0,80 & 7,89 & 10,90 & 30,30 \\
\hline Transmissao Pauli & 2000 & -1.051 .487 & 0,40 & 0,11 & 0,83 & 0,83 & 60,52 \\
\hline Transmissao Pauli & 2001 & -725.551 & 0,30 & 0,20 & 1,69 & 4,18 & 52,97 \\
\hline Trikem PN & 1997 & -704.216 & 0,10 & 0,45 & $-0,50$ & $-1,41$ & 69,43 \\
\hline Trikem PN & 1998 & -777.200 & 0,00 & 0,45 & $-1,40$ & $-4,00$ & 69,43 \\
\hline Trikem PN & 1999 & -570.253 & 0,40 & 0,57 & $-11,84$ & $-32,91$ & 69,43 \\
\hline Trikem PN & 2000 & -73.298 & 0,80 & 0,63 & $-1,33$ & $-1,33$ & 64,43 \\
\hline Trikem PN & 2001 & -237.232 & 0,40 & 0,60 & 10,88 & 45,59 & 64,43 \\
\hline Ultrapar PN & 2000 & 145.271 & 1,10 & 0,26 & 6,68 & 6,68 & 39,64 \\
\hline Ultrapar PN & 2001 & 93.396 & 1,20 & 0,38 & 6,56 & 14,73 & 39,64 \\
\hline Unipar PNB & 1997 & -360.002 & 0,10 & 0,42 & 2,12 & 3,99 & 52,01 \\
\hline Unipar PNB & 1998 & -300.904 & 0,10 & 0,35 & 5,81 & 11,43 & 52,01 \\
\hline Unipar PNB & 1999 & -124.544 & 0,50 & 0,32 & 24,47 & 44,69 & 52,01 \\
\hline Unipar PNB & 2000 & -169.683 & 0,60 & 0,41 & 13,04 & 13,04 & 52,01 \\
\hline Unipar PNB & 2001 & -221.828 & 0,60 & 0,39 & 11,92 & 19,06 & 57,31 \\
\hline Usiminas ON & 1997 & -829.319 & 0,70 & 0,41 & 0,37 & 1,09 & 49,79 \\
\hline Usiminas ON & 1998 & -2.113 .073 & 0,30 & 0,40 & 3,56 & 10,60 & 22,99 \\
\hline Usiminas ON & 1999 & -1.808 .903 & 0,40 & 0,48 & 3,17 & 9,35 & 22,99 \\
\hline Usiminas ON & 2000 & -2.058 .367 & 0,40 & 0,52 & 1,80 & 1,80 & 22,99 \\
\hline Usiminas ON & 2001 & -2.301 .536 & 0,30 & 0,57 & 1,90 & 7,04 & 22,99 \\
\hline V C P & 1997 & -1.065 .200 & 0,40 & 0,40 & 4,14 & 6,00 & 88,95 \\
\hline V C P & 1998 & -1.396 .117 & 0,30 & 0,28 & $-0,24$ & $-0,37$ & 88,95 \\
\hline VCP & 1999 & 1.325 .388 & 1,60 & 1,07 & 5,29 & 8,70 & 88,95 \\
\hline V C P & 2000 & 122.333 & 0,90 & 0,56 & 11,97 & 11,97 & 88,95 \\
\hline V C P & 2001 & 777.645 & 1,20 & 0,90 & 10,77 & 16,20 & 88,95 \\
\hline Vale Rio Doce PNA & 1999 & 9.715 .667 & 1,80 & 1,16 & 7,43 & 12,88 & 42,18 \\
\hline Vale Rio Doce PNA & 2000 & 6.652 .878 & 1,60 & 0,94 & 10,79 & 10,79 & 42,18 \\
\hline Vale Rio Doce PNA & 2001 & 10.300 .029 & 1,80 & 1,05 & 12,80 & 28,87 & 42,20 \\
\hline
\end{tabular}




\begin{tabular}{l|l|r|r|r|r|r|r}
\hline \multicolumn{1}{c|}{ Empresas } & Ano & \multicolumn{1}{c|}{ MVA } & P_VPA & TOBIN'S Q & RENT_ATI & RENT_PL & OWNER_1 \\
\hline Varig PN & 1997 & -35.674 & 0,70 & 0,67 & $-4,24$ & $-55,87$ & 87,24 \\
Varig PN & 1998 & -223.961 & 0,70 & 0,60 & $-0,74$ & $-8,84$ & 87,27 \\
Varig PN & 1999 & 73.280 & 5,60 & 0,48 & $-2,18$ & $-52,99$ & 87,28 \\
Varig PN & 2000 & 221.850 & 1,70 & 0,66 & $-6,37$ & $-597,38$ & 87,29 \\
Varig PN & 2001 & 259.836 & 0,20 & 0,47 & $-15,62$ & $-323,49$ & 87,31
\end{tabular}

CONTINUA 


\begin{tabular}{|c|c|c|c|c|c|c|}
\hline Empresas & Ano & OWNER_12 & OWNER_13 & OWNER_14 & OWNER_15 & $\mathrm{CA} \_\mathrm{NUM}$ \\
\hline AES Tiete PN & 2000 & 71,27 & 71,27 & 71,27 & 71,27 & 3 \\
\hline AES Tiete PN & 2001 & 71,27 & 71,27 & 71,27 & 71,27 & 10 \\
\hline Acesita PN & 1997 & 40,10 & 48,29 & 48,29 & 48,29 & 7 \\
\hline Acesita PN & 1998 & 57,88 & 70,01 & 75,74 & 75,74 & 5 \\
\hline Acesita PN & 1999 & 57,88 & 70,01 & 75,74 & 75,74 & 8 \\
\hline Acesita PN & 2000 & 57,88 & 70,01 & 75,74 & 75,74 & 4 \\
\hline Acesita PN & 2001 & 57,88 & 70,01 & 75,74 & 75,74 & 9 \\
\hline Ambev PN & 2000 & 47,95 & 68,75 & 68,75 & 68,75 & 6 \\
\hline Ambev PN & 2001 & 47,43 & 67,94 & 67,94 & 67,94 & 8 \\
\hline Aracruz PNB & 1997 & 56,00 & 84,00 & 96,49 & 96,49 & 9 \\
\hline Aracruz PNB & 1998 & 56,00 & 84,00 & 96,49 & 96,49 & 8 \\
\hline Aracruz PNB & 1999 & 56,00 & 84,00 & 96,49 & 96,49 & 8 \\
\hline Aracruz PNB & 2000 & 56,00 & 84,00 & 96,49 & 96,49 & 4 \\
\hline Aracruz PNB & 2001 & 56,00 & 84,00 & 96,49 & 96,49 & 8 \\
\hline Bahia Sul PNA & 1999 & 93,65 & 100,00 & 100,00 & 100,00 & 6 \\
\hline Bahia Sul PNA & 2000 & 100,00 & 100,00 & 100,00 & 100,00 & 4 \\
\hline Bahia Sul PNA & 2001 & 100,00 & 100,00 & 100,00 & 100,00 & 8 \\
\hline Bardella PN & 1997 & 51,96 & 59,66 & 67,36 & 75,06 & 9 \\
\hline Bardella PN & 1998 & 52,00 & 59,70 & 67,40 & 75,10 & 8 \\
\hline Bardella PN & 1999 & 60,00 & 67,70 & 75,40 & 83,10 & 7 \\
\hline Bardella PN & 2000 & 60,00 & 67,70 & 75,40 & 83,10 & 12 \\
\hline Bardella PN & 2001 & 60,01 & 67,71 & 75,41 & 83,11 & 8 \\
\hline Belgo Mineira ON & 1998 & 62,09 & 71,46 & 78,78 & 84,61 & 8 \\
\hline Belgo Mineira ON & 1999 & 70,77 & 80,14 & 87,46 & 87,46 & 8 \\
\hline Belgo Mineira ON & 2000 & 70,75 & 80,12 & 87,44 & 87,44 & 13 \\
\hline Belgo Mineira ON & 2001 & 70,76 & 80,18 & 87,50 & 87,50 & 11 \\
\hline Bombril PN & 1997 & 100,00 & 100,00 & 100,00 & 100,00 & 10 \\
\hline Bombril PN & 1998 & 100,00 & 100,00 & 100,00 & 100,00 & 9 \\
\hline Bombril PN & 1999 & 100,00 & 100,00 & 100,00 & 100,00 & 7 \\
\hline Bombril PN & 2000 & 100,00 & 100,00 & 100,00 & 100,00 & 15 \\
\hline Bombril PN & 2001 & 100,00 & 100,00 & 100,00 & 100,00 & 7 \\
\hline Brasil T Par PN & 1999 & 57,18 & 57,18 & 57,18 & 57,18 & 9 \\
\hline Brasil T Par PN & 2000 & 57,63 & 57,63 & 57,63 & 57,63 & 8 \\
\hline Brasil T Par PN & 2001 & 58,66 & 58,66 & 58,66 & 58,66 & 3 \\
\hline Brasil Telecom PN & 1999 & 81,98 & 81,98 & 81,98 & 81,98 & 9 \\
\hline Brasil Telecom PN & 2000 & 98,66 & 98,66 & 98,66 & 98,66 & 8 \\
\hline Brasil Telecom PN & 2001 & 97,71 & 97,71 & 97,71 & 97,71 & 8 \\
\hline CRT Celular PNA & 2000 & 80,23 & 86,14 & 91,78 & 91,78 & 14 \\
\hline CRT Celular PNA & 2001 & 79,99 & 79,99 & 79,99 & 79,99 & 8 \\
\hline Caemi Metal PN & 2000 & 100,00 & 100,00 & 100,00 & 100,00 & 8 \\
\hline Caemi Metal PN & 2001 & 100,00 & 100,00 & 100,00 & 100,00 & 8 \\
\hline Celesc PNB & 1997 & 79,23 & 91,82 & 91,82 & 91,82 & 7 \\
\hline Celesc PNB & 1998 & 79,50 & 92,09 & 92,09 & 92,09 & 7 \\
\hline Celesc PNB & 1999 & 79,50 & 92,09 & 92,09 & 92,09 & 11 \\
\hline Celesc PNB & 2000 & 79,50 & 92,09 & 92,09 & 92,09 & 8 \\
\hline Celesc PNB & 2001 & 79,50 & 92,09 & 97,24 & 97,24 & 4 \\
\hline Cemig PN & 1997 & 83,92 & 83,92 & 83,92 & 83,92 & 10 \\
\hline Cemig PN & 1998 & 83,92 & 83,92 & 83,92 & 83,92 & 8 \\
\hline Cemig PN & 1999 & 83,92 & 83,92 & 83,92 & 83,92 & 11 \\
\hline Cemig PN & 2000 & 83,92 & 83,92 & 83,92 & 83,92 & 8 \\
\hline
\end{tabular}




\begin{tabular}{|c|c|c|c|c|c|c|}
\hline Empresas & Ano & OWNER_12 & OWNER_13 & OWNER_14 & OWNER_15 & CA_NUM \\
\hline Cemig PN & 2001 & 83,92 & 83,92 & 83,92 & 83,92 & 4 \\
\hline Cesp PN & 1998 & 53,28 & 63,86 & 83,70 & 83,78 & 7 \\
\hline Cesp PN & 2000 & 73,13 & 83,71 & 83,71 & 83,71 & 5 \\
\hline Cesp PN & 2001 & 73,13 & 83,71 & 83,71 & 83,71 & 4 \\
\hline Cim Itau PN & 1997 & 90,63 & 90,63 & 90,63 & 90,63 & 10 \\
\hline Cim Itau PN & 1998 & 90,65 & 90,65 & 90,65 & 90,65 & 11 \\
\hline Cim Itau PN & 1999 & 98,53 & 98,53 & 98,53 & 98,53 & 11 \\
\hline Cim Itau PN & 2000 & 98,53 & 98,53 & 98,53 & 98,53 & 5 \\
\hline Cim Itau PN & 2001 & 98,53 & 98,53 & 98,53 & 98,53 & 3 \\
\hline Coelce PNA & 1998 & 89,78 & 89,78 & 89,78 & 89,78 & 6 \\
\hline Coelce PNA & 1999 & 91,66 & 91,66 & 91,66 & 91,66 & 11 \\
\hline Coelce PNA & 2000 & 91,66 & 91,66 & 91,66 & 91,66 & 5 \\
\hline Coelce PNA & 2001 & 91,66 & 91,66 & 91,66 & 91,66 & 3 \\
\hline Comgas PNA & 1997 & 94,94 & 98,87 & 98,87 & 98,87 & 10 \\
\hline Comgas PNA & 1998 & 94,94 & 98,87 & 99,89 & 99,97 & 6 \\
\hline Comgas PNA & 1999 & 95,96 & 99,89 & 99,97 & 99,97 & 11 \\
\hline Comgas PNA & 2000 & 95,96 & 99,89 & 99,97 & 99,97 & 5 \\
\hline Comgas PNA & 2001 & 95,96 & 99,89 & 99,97 & 99,97 & 3 \\
\hline Confab PN & 1997 & 72,97 & 79,43 & 82,85 & 86,26 & 10 \\
\hline Confab PN & 1998 & 99,69 & 99,87 & 99,92 & 99,96 & 11 \\
\hline Confab PN & 1999 & 99,22 & 99,22 & 99,22 & 99,22 & 7 \\
\hline Confab PN & 2000 & 99,00 & 99,00 & 99,00 & 99,00 & 5 \\
\hline Confab PN & 2001 & 99,00 & 99,00 & 99,00 & 99,00 & 11 \\
\hline Copel PNB & 1997 & 85,00 & 85,00 & 85,00 & 85,00 & 10 \\
\hline Copel PNB & 1998 & 85,00 & 85,00 & 85,00 & 85,00 & 6 \\
\hline Copel PNB & 2000 & 85,04 & 85,04 & 85,04 & 85,04 & 17 \\
\hline Copel PNB & 2001 & 85,04 & 85,04 & 85,04 & 85,04 & 11 \\
\hline Copene PNA & 1997 & 73,81 & 79,63 & 85,35 & 85,35 & 10 \\
\hline Copene PNA & 1998 & 73,81 & 79,63 & 85,35 & 85,35 & 6 \\
\hline Copene PNA & 1999 & 73,81 & 79,63 & 85,35 & 85,35 & 7 \\
\hline Copene PNA & 2000 & 73,81 & 79,63 & 85,35 & 85,35 & 16 \\
\hline Copene PNA & 2001 & 73,81 & 79,63 & 85,35 & 85,35 & 11 \\
\hline Cosipa PN & 2000 & 95,92 & 97,04 & 97,61 & 97,61 & 15 \\
\hline Cosipa PN & 2001 & 95,92 & 97,04 & 97,61 & 97,61 & 8 \\
\hline Coteminas PN & 2000 & 59,94 & 59,94 & 59,94 & 59,94 & 13 \\
\hline Coteminas PN & 2001 & 59,94 & 70,05 & 76,02 & 81,99 & 9 \\
\hline Duratex PN & 1997 & 82,07 & 82,07 & 82,07 & 82,07 & 7 \\
\hline Duratex PN & 1998 & 82,07 & 82,07 & 82,07 & 82,07 & 10 \\
\hline Duratex PN & 1999 & 82,17 & 82,17 & 82,17 & 82,17 & 18 \\
\hline Duratex PN & 2000 & 84,49 & 84,49 & 84,49 & 84,49 & 6 \\
\hline Duratex PN & 2001 & 84,49 & 84,60 & 84,60 & 84,60 & 4 \\
\hline EMAE PN & 2000 & 97,44 & 97,44 & 97,44 & 97,44 & 6 \\
\hline EMAE PN & 2001 & 97,44 & 97,44 & 97,44 & 97,44 & 23 \\
\hline Eletrobras PNB & 1997 & 72,19 & 80,86 & 80,86 & 80,86 & 7 \\
\hline Eletrobras PNB & 1998 & 73,42 & 78,46 & 78,46 & 78,46 & 12 \\
\hline Eletrobras PNB & 1999 & 72,30 & 77,34 & 77,34 & 77,34 & 19 \\
\hline Eletrobras PNB & 2000 & 73,62 & 78,66 & 78,66 & 78,66 & 5 \\
\hline Eletrobras PNB & 2001 & 72,84 & 77,88 & 77,88 & 77,88 & 5 \\
\hline Eletropaulo Metro & 1999 & 38,94 & 38,94 & 38,94 & 38,94 & 5 \\
\hline Eletropaulo Metro & 2000 & 97,84 & 97,84 & 97,84 & 97,84 & 6 \\
\hline Eletropaulo Metro & 2001 & 97,84 & 97,84 & 97,84 & 97,84 & 10 \\
\hline Embraer ON & 1999 & 44,43 & 64,43 & 70,10 & 75,77 & 5 \\
\hline Embraer ON & 2000 & 44,43 & 64,43 & 70,10 & 75,77 & 6 \\
\hline
\end{tabular}




\begin{tabular}{|c|c|c|c|c|c|c|}
\hline Empresas & Ano & OWNER_12 & OWNER_13 & OWNER_14 & OWNER_15 & $\mathrm{CA} \quad \mathrm{NUM}$ \\
\hline Embraer ON & 2001 & 43,75 & 63,75 & 69,42 & 75,09 & 17 \\
\hline Embratel Part PN & 1999 & 57,19 & 57,19 & 57,19 & 57,19 & 11 \\
\hline Embratel Part PN & 2000 & 51,79 & 57,19 & 57,19 & 57,19 & 24 \\
\hline Embratel Part PN & 2001 & 51,79 & 57,19 & 57,19 & 57,19 & 7 \\
\hline F Cataguazes PNA & 1998 & 72,60 & 81,80 & 81,80 & 81,80 & 11 \\
\hline F Cataguazes PNA & 1999 & 72,60 & 81,80 & 81,80 & 81,80 & 11 \\
\hline F Cataguazes PNA & 2000 & 72,60 & 81,80 & 81,80 & 81,80 & 28 \\
\hline F Cataguazes PNA & 2001 & 72,60 & 81,80 & 87,80 & 94,30 & 11 \\
\hline Fosfertil PN & 1998 & 80,84 & 88,07 & 88,07 & 88,07 & 11 \\
\hline Fosfertil PN & 1999 & 80,84 & 88,08 & 88,08 & 88,08 & 11 \\
\hline Fosfertil PN & 2000 & 92,50 & 92,50 & 92,50 & 92,50 & 28 \\
\hline Fosfertil PN & 2001 & 92,50 & 92,50 & 92,50 & 92,50 & 11 \\
\hline Gerasul - Tracteb & 2000 & 80,42 & 80,42 & 80,42 & 80,42 & 20 \\
\hline Gerasul - Tracteb & 2001 & 80,42 & 80,42 & 80,42 & 80,42 & 3 \\
\hline Gerdau Met PN & 1997 & 59,34 & 64,54 & 69,58 & 69,58 & 6 \\
\hline Gerdau Met PN & 1998 & 57,65 & 69,61 & 74,82 & 79,86 & 11 \\
\hline Gerdau Met PN & 1999 & 56,16 & 69,62 & 69,62 & 69,62 & 11 \\
\hline Gerdau Met PN & 2000 & 57,87 & 71,79 & 71,79 & 71,79 & 26 \\
\hline Gerdau Met PN & 2001 & 57,87 & 71,79 & 71,79 & 71,79 & 6 \\
\hline Gerdau ON & 1997 & 87,71 & 87,71 & 87,71 & 87,71 & 9 \\
\hline Gerdau ON & 1998 & 87,71 & 87,71 & 87,71 & 87,71 & 11 \\
\hline Gerdau ON & 1999 & 87,97 & 87,97 & 87,97 & 87,97 & 9 \\
\hline Gerdau ON & 2000 & 89,87 & 89,87 & 89,87 & 89,87 & 3 \\
\hline Gerdau ON & 2001 & 89,93 & 89,93 & 89,93 & 89,93 & 5 \\
\hline Globo Cabo - Net & 1999 & 77,57 & 77,58 & 81,49 & 91,14 & 8 \\
\hline Globo Cabo - Net & 2000 & 70,67 & 79,33 & 87,29 & 96,49 & 3 \\
\hline Globo Cabo - Net & 2001 & 64,30 & 72,96 & 85,56 & 95,76 & 5 \\
\hline Inepar Construcoe & 1997 & 80,25 & 91,01 & 96,39 & 96,39 & 10 \\
\hline Inepar Construcoes & 1998 & 70,68 & 90,68 & 96,06 & 96,06 & 11 \\
\hline Inepar Construcoes & 1999 & 70,68 & 90,68 & 96,06 & 96,06 & 7 \\
\hline Inepar Construcoes & 2000 & 70,68 & 90,68 & 96,06 & 96,06 & 3 \\
\hline Inepar Construcoes & 2001 & 70,68 & 90,68 & 96,06 & 96,06 & 5 \\
\hline lochp-Maxion PN & 1997 & 74,27 & 74,27 & 74,27 & 74,27 & 10 \\
\hline lochp-Maxion PN & 1998 & 64,47 & 83,91 & 83,91 & 83,91 & 11 \\
\hline lochp-Maxion PN & 1999 & 51,04 & 64,47 & 66,80 & 86,24 & 10 \\
\hline lochp-Maxion PN & 2000 & 51,04 & 64,47 & 66,80 & 86,24 & 3 \\
\hline lochp-Maxion PN & 2001 & 64,47 & 66,80 & 86,24 & 86,24 & 5 \\
\hline Ipiranga Pet PN & 1997 & 87,33 & 87,33 & 87,33 & 87,33 & 10 \\
\hline Ipiranga Pet PN & 1998 & 87,56 & 87,56 & 87,56 & 87,56 & 11 \\
\hline Ipiranga Pet PN & 1999 & 87,66 & 87,66 & 87,66 & 87,66 & 8 \\
\hline Ipiranga Pet PN & 2000 & 87,68 & 87,68 & 87,68 & 87,68 & 3 \\
\hline Ipiranga Pet PN & 2001 & 87,68 & 87,68 & 87,68 & 87,68 & 19 \\
\hline Itausa PN & 1998 & 24,18 & 32,29 & 38,02 & 45,20 & 11 \\
\hline Itausa PN & 1999 & 21,96 & 27,75 & 37,83 & 37,83 & 11 \\
\hline Itausa PN & 2000 & 22,84 & 32,89 & 32,89 & 32,89 & 14 \\
\hline Itausa PN & 2001 & 22,92 & 32,97 & 32,97 & 32,97 & 15 \\
\hline Klabin PN & 1997 & 82,66 & 99,42 & 99,42 & 99,42 & 5 \\
\hline Klabin PN & 1998 & 82,66 & 99,42 & 99,42 & 99,42 & 13 \\
\hline Klabin PN & 1999 & 82,66 & 99,42 & 99,42 & 99,42 & 9 \\
\hline Klabin PN & 2000 & 99,77 & 99,77 & 99,77 & 99,77 & 5 \\
\hline Kuala PN & 1999 & 64,20 & 73,46 & 73,46 & 73,46 & 9 \\
\hline Kuala PN & 2000 & 64,20 & 73,46 & 73,46 & 73,46 & 5 \\
\hline Kuala PN & 2001 & 66,03 & 77,19 & 77,19 & 77,19 & 13 \\
\hline
\end{tabular}




\begin{tabular}{|c|c|c|c|c|c|c|}
\hline Empresas & Ano & OWNER_12 & OWNER_13 & OWNER_14 & OWNER_15 & $\mathrm{CA} \quad \mathrm{NUM}$ \\
\hline Light ON & 2000 & 45,45 & 50,93 & 79,96 & 83,16 & 5 \\
\hline Light ON & 2001 & 88,21 & 88,21 & 88,21 & 88,21 & 16 \\
\hline Lojas Americanas & 1998 & 48,11 & 48,11 & 48,11 & 48,11 & 16 \\
\hline Lojas Americanas & 2000 & 48,20 & 48,20 & 48,20 & 48,20 & 8 \\
\hline Lojas Americanas & 2001 & 56,31 & 56,31 & 56,31 & 56,31 & 16 \\
\hline Magnesita PNA & 1997 & 62,00 & 70,00 & 70,00 & 70,00 & 5 \\
\hline Magnesita PNA & 1998 & 58,46 & 65,50 & 65,50 & 65,50 & 15 \\
\hline Magnesita PNA & 1999 & 58,88 & 65,97 & 72,43 & 72,43 & 16 \\
\hline Magnesita PNA & 2000 & 58,03 & 65,02 & 65,02 & 65,02 & 6 \\
\hline Magnesita PNA & 2001 & 58,03 & 65,02 & 70,71 & 70,71 & 7 \\
\hline PETROBRAS BR & 1998 & 99,86 & 99,86 & 99,86 & 99,86 & 10 \\
\hline PETROBRAS BR & 1999 & 99,86 & 99,86 & 99,86 & 99,86 & 13 \\
\hline PETROBRAS BR & 2000 & 99,86 & 99,86 & 99,86 & 99,86 & 6 \\
\hline PETROBRAS BR & 2001 & 99,86 & 99,86 & 99,86 & 99,86 & 6 \\
\hline Petrobras PN & 1999 & 55,70 & 55,70 & 55,70 & 55,70 & 13 \\
\hline Petrobras PN & 2000 & 55,70 & 55,70 & 55,70 & 55,70 & 18 \\
\hline Petrobras PN & 2001 & 55,71 & 55,71 & 55,71 & 55,71 & 6 \\
\hline Plascar PN & 1997 & 99,99 & 99,99 & 99,99 & 99,99 & 5 \\
\hline Plascar PN & 1998 & 99,99 & 99,99 & 99,99 & 99,99 & 9 \\
\hline Plascar PN & 1999 & 99,99 & 99,99 & 99,99 & 99,99 & 14 \\
\hline Plascar PN & 2000 & 99,99 & 99,99 & 99,99 & 99,99 & 19 \\
\hline Plascar PN & 2001 & 99,99 & 99,99 & 99,99 & 99,99 & 6 \\
\hline Ripasa PN & 1997 & 97,00 & 97,00 & 97,00 & 97,00 & 9 \\
\hline Ripasa PN & 1998 & 97,00 & 97,00 & 97,00 & 97,00 & 8 \\
\hline Ripasa PN & 1999 & 98,00 & 98,00 & 98,00 & 98,00 & 14 \\
\hline Ripasa PN & 2000 & 98,00 & 98,00 & 98,00 & 98,00 & 12 \\
\hline Ripasa PN & 2001 & 97,66 & 97,66 & 97,66 & 97,66 & 6 \\
\hline Sabesp ON & 1997 & 87,77 & 87,77 & 87,77 & 87,77 & 9 \\
\hline Sabesp ON & 1998 & 86,38 & 86,38 & 86,38 & 86,38 & 9 \\
\hline Sabesp ON & 1999 & 85,39 & 85,39 & 85,39 & 85,39 & 5 \\
\hline Sabesp ON & 2000 & 85,30 & 85,30 & 85,30 & 85,30 & 12 \\
\hline Sabesp ON & 2001 & 71,55 & 71,55 & 71,55 & 71,55 & 4 \\
\hline Sid Nacional ON & 1998 & 34,44 & 48,28 & 58,61 & 66,39 & 7 \\
\hline Sid Nacional ON & 1999 & 32,02 & 42,35 & 56,20 & 61,41 & 7 \\
\hline Sid Nacional ON & 2000 & 56,81 & 56,81 & 56,81 & 56,81 & 9 \\
\hline Sid Nacional ON & 2001 & 56,81 & 56,81 & 56,81 & 56,81 & 4 \\
\hline Sid Tubarao PN & 1997 & 59,67 & 84,93 & 84,93 & 84,93 & 9 \\
\hline Sid Tubarao PN & 1998 & 64,42 & 84,93 & 88,93 & 88,93 & 20 \\
\hline Sid Tubarao PN & 1999 & 64,42 & 84,93 & 84,93 & 84,93 & 7 \\
\hline Sid Tubarao PN & 2000 & 64,42 & 84,93 & 84,93 & 84,93 & 8 \\
\hline Sid Tubarao PN & 2001 & 64,42 & 84,93 & 84,93 & 84,93 & 4 \\
\hline Suzano PN & 2000 & 99,99 & 99,99 & 99,99 & 99,99 & 8 \\
\hline Suzano PN & 2001 & 99,99 & 99,99 & 99,99 & 99,99 & 8 \\
\hline Tele Celular Sul & 1999 & 57,20 & 57,20 & 57,20 & 57,20 & 7 \\
\hline Tele Celular Sul & 2000 & 56,72 & 56,72 & 56,72 & 56,72 & 8 \\
\hline Tele Celular Sul & 2001 & 57,43 & 57,43 & 57,43 & 57,43 & 6 \\
\hline Tele Centroeste C & 2000 & 65,56 & 73,38 & 78,70 & 78,70 & 8 \\
\hline Tele Centroeste C & 2001 & 64,80 & 73,37 & 78,58 & 78,58 & 8 \\
\hline Tele Leste Celula & 1999 & 54,62 & 54,62 & 54,62 & 54,62 & 7 \\
\hline Tele Leste Celula & 2000 & 56,89 & 58,33 & 58,42 & 58,42 & 7 \\
\hline Tele Leste Celula & 2001 & 56,98 & 58,42 & 58,42 & 58,42 & 6 \\
\hline Tele Nordeste Cel & 1999 & 57,18 & 65,44 & 65,44 & 65,44 & 7 \\
\hline Tele Nordeste Cel & 2000 & 56,65 & 64,00 & 69,61 & 69,61 & 9 \\
\hline
\end{tabular}




\begin{tabular}{|c|c|c|c|c|c|c|}
\hline Empresas & Ano & OWNER_12 & OWNER_13 & OWNER_14 & OWNER_15 & CA_NUM \\
\hline Tele Nordeste Cel & 2001 & 56,61 & 63,21 & 69,15 & 69,15 & 6 \\
\hline Tele Norte Celula & 1999 & 57,18 & 57,18 & 57,18 & 57,18 & 7 \\
\hline Tele Norte Celula & 2000 & 57,22 & 68,25 & 68,25 & 68,25 & 6 \\
\hline Tele Norte Celula & 2001 & 57,26 & 64,56 & 64,56 & 64,56 & 13 \\
\hline Tele Sudeste Celu & 1999 & 84,90 & 84,90 & 84,90 & 84,90 & 8 \\
\hline Tele Sudeste Celu & 2000 & 78,95 & 83,98 & 83,98 & 83,98 & 6 \\
\hline Tele Sudeste Celu & 2001 & 79,76 & 85,92 & 85,92 & 85,92 & 7 \\
\hline Telemar Norte Les & 1999 & 95,79 & 95,79 & 95,79 & 95,79 & 9 \\
\hline Telemar Norte Les & 2000 & 95,79 & 95,79 & 95,79 & 95,79 & 6 \\
\hline Telemar Norte Les & 2001 & 97,24 & 97,24 & 97,24 & 97,24 & 10 \\
\hline Telemar PN & 2000 & 52,26 & 52,26 & 52,26 & 52,26 & 5 \\
\hline Telemar PN & 2001 & 52,96 & 52,96 & 52,96 & 52,96 & 10 \\
\hline Telemig Celul Par & 1999 & 57,18 & 57,18 & 57,18 & 57,18 & 9 \\
\hline Telemig Celul Par & 2000 & 12,86 & 64,75 & 71,35 & 71,35 & 5 \\
\hline Telemig Celul Par & 2001 & 12,70 & 64,59 & 70,83 & 70,83 & 10 \\
\hline Telemig Celular P & 1999 & 89,18 & 89,18 & 89,18 & 89,18 & 9 \\
\hline Telemig Celular P & 2000 & 89,18 & 89,18 & 89,18 & 89,18 & 6 \\
\hline Telemig Celular P & 2001 & 89,18 & 89,18 & 89,18 & 89,18 & 7 \\
\hline Telepar Celular P & 1999 & 81,98 & 81,98 & 81,98 & 81,98 & 7 \\
\hline Telepar Celular P & 2000 & 87,43 & 87,43 & 87,43 & 87,43 & 3 \\
\hline Telepar Celular P & 2001 & 87,43 & 87,43 & 87,43 & 87,43 & 7 \\
\hline Telesp Cel Part P & 2000 & 85,06 & 85,06 & 85,06 & 85,06 & 6 \\
\hline Telesp Cel Part P & 2001 & 85,06 & 85,06 & 85,06 & 85,06 & 7 \\
\hline Telesp Operac PN & 1999 & 76,50 & 84,34 & 84,34 & 84,34 & 7 \\
\hline Telesp Operac PN & 2000 & 76,50 & 84,34 & 84,34 & 84,34 & 6 \\
\hline Telesp Operac PN & 2001 & 76,50 & 84,34 & 84,34 & 84,34 & 7 \\
\hline Transmissao Pauli & 2000 & 71,10 & 83,79 & 83,79 & 83,79 & 7 \\
\hline Transmissao Pauli & 2001 & 61,18 & 71,03 & 86,31 & 86,31 & 6 \\
\hline Trikem PN & 1997 & 69,43 & 69,43 & 69,43 & 69,43 & 9 \\
\hline Trikem PN & 1998 & 69,43 & 69,43 & 69,43 & 69,43 & 21 \\
\hline Trikem PN & 1999 & 69,43 & 69,43 & 69,43 & 69,43 & 3 \\
\hline Trikem PN & 2000 & 64,43 & 64,43 & 64,43 & 64,43 & 13 \\
\hline Trikem PN & 2001 & 74,49 & 87,91 & 87,91 & 87,91 & 9 \\
\hline Ultrapar PN & 2000 & 69,48 & 93,99 & 93,99 & 93,99 & 9 \\
\hline Ultrapar PN & 2001 & 69,48 & 93,99 & 93,99 & 93,99 & 9 \\
\hline Unipar PNB & 1997 & 90,77 & 90,77 & 90,77 & 90,77 & 8 \\
\hline Unipar PNB & 1998 & 90,77 & 90,77 & 90,77 & 90,77 & 21 \\
\hline Unipar PNB & 1999 & 90,77 & 90,77 & 90,77 & 90,77 & 3 \\
\hline Unipar PNB & 2000 & 52,01 & 52,01 & 52,01 & 52,01 & 7 \\
\hline Unipar PNB & 2001 & 57,31 & 57,31 & 57,31 & 57,31 & 9 \\
\hline Usiminas ON & 1997 & 62,21 & 72,49 & 77,70 & 77,70 & 7 \\
\hline Usiminas ON & 1998 & 41,38 & 56,28 & 66,22 & 73,47 & 11 \\
\hline Usiminas ON & 1999 & 37,89 & 56,28 & 66,22 & 73,47 & 3 \\
\hline Usiminas ON & 2000 & 37,89 & 56,28 & 66,22 & 73,47 & 7 \\
\hline Usiminas ON & 2001 & 37,89 & 56,28 & 66,22 & 73,47 & 9 \\
\hline VCP & 1997 & 100,00 & 100,00 & 100,00 & 100,00 & 7 \\
\hline V C P & 1998 & 100,00 & 100,00 & 100,00 & 100,00 & 6 \\
\hline V C P & 1999 & 100,00 & 100,00 & 100,00 & 100,00 & 8 \\
\hline VCP & 2000 & 100,00 & 100,00 & 100,00 & 100,00 & 11 \\
\hline V C P & 2001 & 100,00 & 100,00 & 100,00 & 100,00 & 9 \\
\hline Vale Rio Doce PNA & 1999 & 57,94 & 73,70 & 83,81 & 83,81 & 3 \\
\hline Vale Rio Doce PNA & 2000 & 57,94 & 68,05 & 68,05 & 68,05 & 11 \\
\hline Vale Rio Doce PNA & 2001 & 52,30 & 52,30 & 52,30 & 52,30 & 7 \\
\hline
\end{tabular}




\begin{tabular}{l|l|r|r|r|r|r}
\hline \multicolumn{1}{c|}{ Empresas } & Ano & OWNER_12 & OWNER_13 & OWNER_14 & OWNER_15 & CA_NUM \\
\hline Varig PN & 1997 & 95,13 & 95,13 & 95,13 & 95,13 & 5 \\
Varig PN & 1998 & 95,17 & 95,17 & 95,17 & 95,17 & 8 \\
Varig PN & 1999 & 87,28 & 87,28 & 87,28 & 87,28 & 4 \\
Varig PN & 2000 & 87,29 & 87,29 & 87,29 & 87,29 & 11 \\
Varig PN & 2001 & 95,21 & 95,21 & 95,21 & 95,21 & 7 \\
\hline
\end{tabular}

CONTINUA 


\begin{tabular}{|c|c|c|c|c|c|c|}
\hline Empresas & Ano & CA_DIR & D1_CHAIR & PERT_AO & D2_LUCRO & REMUN_A \\
\hline AES Tiete PN & 2000 & 66,67 & 1 & 51,81 & 0 & $1.000,00$ \\
\hline AES Tiete PN & 2001 & 10,00 & 1 & 51,81 & 0 & 144,00 \\
\hline Acesita PN & 1997 & 14,29 & 0 & 66,69 & 1 & $2.636,00$ \\
\hline Acesita PN & 1998 & 20,00 & 0 & 50,26 & 1 & $2.589,00$ \\
\hline Acesita PN & 1999 & 0,00 & 0 & 33,40 & 1 & $2.483,00$ \\
\hline Acesita PN & 2000 & 25,00 & 0 & 33,40 & 1 & $2.949,00$ \\
\hline Acesita PN & 2001 & 0,00 & 0 & 33,40 & 1 & $3.463,00$ \\
\hline Ambev PN & 2000 & 16,67 & 0 & 40,74 & 1 & 100,00 \\
\hline Ambev PN & 2001 & 12,50 & 0 & 40,39 & 1 & 100,00 \\
\hline Aracruz PNB & 1997 & 11,11 & 0 & 42,25 & 0 & $3.593,00$ \\
\hline Aracruz PNB & 1998 & 0,00 & 0 & 42,25 & 0 & $3.593,00$ \\
\hline Aracruz PNB & 1999 & 0,00 & 0 & 42,25 & 0 & $2.701,00$ \\
\hline Aracruz PNB & 2000 & 50,00 & 0 & 42,25 & 0 & $3.110,00$ \\
\hline Aracruz PNB & 2001 & 12,50 & 0 & 42,25 & 0 & $5.010,00$ \\
\hline Bahia Sul PNA & 1999 & 16,67 & 0 & 42,44 & 0 & $2.549,00$ \\
\hline Bahia Sul PNA & 2000 & 50,00 & 0 & 42,41 & 1 & $4.431,00$ \\
\hline Bahia Sul PNA & 2001 & 0,00 & 0 & 42,35 & 1 & $5.361,00$ \\
\hline Bardella PN & 1997 & 0,00 & 0 & 37,94 & 1 & $1.182,00$ \\
\hline Bardella PN & 1998 & 0,00 & 1 & 37,94 & 1 & $1.316,00$ \\
\hline Bardella PN & 1999 & 28,57 & 1 & 37,94 & 1 & $1.568,00$ \\
\hline Bardella PN & 2000 & 33,33 & 1 & 37,94 & 1 & $1.589,00$ \\
\hline Bardella PN & 2001 & 0,00 & 1 & 37,94 & 1 & $1.635,00$ \\
\hline Belgo Mineira ON & 1998 & 25,00 & 0 & 57,75 & 1 & $2.100,00$ \\
\hline Belgo Mineira ON & 1999 & 25,00 & 0 & 57,75 & 1 & $2.000,00$ \\
\hline Belgo Mineira ON & 2000 & 38,46 & 0 & 57,74 & 1 & $2.000,00$ \\
\hline Belgo Mineira ON & 2001 & 18,18 & 0 & 57,74 & 1 & $2.200,00$ \\
\hline Bombril PN & 1997 & 0,00 & 0 & 37,78 & 0 & $3.800,00$ \\
\hline Bombril PN & 1998 & 0,00 & 0 & 37,78 & 0 & $3.500,00$ \\
\hline Bombril PN & 1999 & 28,57 & 0 & 37,78 & 0 & $3.800,00$ \\
\hline Bombril PN & 2000 & 13,33 & 0 & 37,78 & 0 & $3.800,00$ \\
\hline Bombril PN & 2001 & 28,57 & 0 & 37,78 & 0 & $6.500,00$ \\
\hline Brasil T Par PN & 1999 & 22,22 & 0 & 37,19 & 0 & $3.500,00$ \\
\hline Brasil T Par PN & 2000 & 12,50 & 0 & 36,88 & 0 & $7.500,00$ \\
\hline Brasil T Par PN & 2001 & 0,00 & 0 & 37,58 & 0 & $7.000,00$ \\
\hline Brasil Telecom PN & 1999 & 11,11 & 0 & 42,93 & 0 & $7.225,00$ \\
\hline Brasil Telecom PN & 2000 & 0,00 & 0 & 44,52 & 0 & $9.800,00$ \\
\hline Brasil Telecom PN & 2001 & 12,50 & 0 & 45,18 & 0 & $13.000,00$ \\
\hline CRT Celular PNA & 2000 & 21,43 & 0 & 36,10 & 0 & $1.900,00$ \\
\hline CRT Celular PNA & 2001 & 12,50 & 0 & 38,10 & 0 & 576,00 \\
\hline Caemi Metal PN & 2000 & 0,00 & 0 & 33,64 & 0 & $1.800,00$ \\
\hline Caemi Metal PN & 2001 & 12,50 & 0 & 33,65 & 0 & $2.800,00$ \\
\hline Celesc PNB & 1997 & 0,00 & 0 & 40,26 & 1 & 12,00 \\
\hline Celesc PNB & 1998 & 28,57 & 0 & 40,26 & 1 & 15,00 \\
\hline Celesc PNB & 1999 & 18,18 & 0 & 40,26 & 1 & 3,00 \\
\hline Celesc PNB & 2000 & 0,00 & 0 & 40,26 & 1 & 8,00 \\
\hline Celesc PNB & 2001 & 25,00 & 0 & 40,26 & 1 & 10,00 \\
\hline Cemig PN & 1997 & 0,00 & 0 & 43,71 & 1 & 134,00 \\
\hline Cemig PN & 1998 & 25,00 & 1 & 43,71 & 1 & 121,00 \\
\hline Cemig PN & 1999 & 9,09 & 1 & 43,71 & 1 & $1.673,00$ \\
\hline Cemig PN & 2000 & 0,00 & 0 & 43,71 & 1 & $1.449,00$ \\
\hline
\end{tabular}




\begin{tabular}{|c|c|c|c|c|c|c|}
\hline Empresas & Ano & CA_DIR & D1_CHAIR & PERT_AO & D2_LUCRO & REMUN_A \\
\hline Cemig PN & 2001 & 50,00 & 0 & 43,71 & 1 & $1.707,00$ \\
\hline Cesp PN & 1998 & 28,57 & 0 & 51,81 & 0 & 62,00 \\
\hline Cesp PN & 2000 & 20,00 & 0 & 51,81 & 0 & $3.190,00$ \\
\hline Cesp PN & 2001 & 25,00 & 0 & 51,81 & 0 & $3.190,00$ \\
\hline Cim Itau PN & 1997 & 0,00 & 0 & 59,56 & 0 & $1.830,00$ \\
\hline Cim Itau PN & 1998 & 0,00 & 0 & 59,56 & 0 & $1.700,00$ \\
\hline Cim Itau PN & 1999 & 9,09 & 0 & 62,07 & 0 & $1.700,00$ \\
\hline Cim Itau PN & 2000 & 20,00 & 1 & 62,07 & 0 & $1.700,00$ \\
\hline Cim Itau PN & 2001 & 0,00 & 0 & 62,07 & 0 & $1.700,00$ \\
\hline Coelce PNA & 1998 & 0,00 & 0 & 61,74 & 0 & $1.700,00$ \\
\hline Coelce PNA & 1999 & 0,00 & 0 & 61,74 & 1 & $1.700,00$ \\
\hline Coelce PNA & 2000 & 20,00 & 0 & 61,74 & 1 & $1.706,00$ \\
\hline Coelce PNA & 2001 & 0,00 & 0 & 61,74 & 1 & $3.500,00$ \\
\hline Comgas PNA & 1997 & 0,00 & 0 & 81,29 & 0 & 343,00 \\
\hline Comgas PNA & 1998 & 0,00 & 0 & 78,37 & 0 & 347,00 \\
\hline Comgas PNA & 1999 & 0,00 & 0 & 78,37 & 0 & 345,00 \\
\hline Comgas PNA & 2000 & 20,00 & 0 & 78,37 & 0 & 344,00 \\
\hline Comgas PNA & 2001 & 0,00 & 0 & 78,37 & 0 & 347,00 \\
\hline Confab PN & 1997 & 0,00 & 0 & 39,29 & 1 & 821,00 \\
\hline Confab PN & 1998 & 0,00 & 0 & 100,00 & 1 & $1.421,00$ \\
\hline Confab PN & 1999 & 14,29 & 1 & 100,00 & 1 & $3.400,00$ \\
\hline Confab PN & 2000 & 20,00 & 1 & 39,29 & 1 & $3.400,00$ \\
\hline Confab PN & 2001 & 9,09 & 0 & 39,29 & 1 & $3.400,00$ \\
\hline Copel PNB & 1997 & 0,00 & 0 & 53,00 & 1 & $1.873,00$ \\
\hline Copel PNB & 1998 & 0,00 & 0 & 53,00 & 1 & $3.200,00$ \\
\hline Copel PNB & 2000 & 23,53 & 1 & 53,00 & 1 & $3.200,00$ \\
\hline Copel PNB & 2001 & 9,09 & 0 & 53,00 & 0 & $3.700,00$ \\
\hline Copene PNA & 1997 & 0,00 & 0 & 36,08 & 1 & $1.600,00$ \\
\hline Copene PNA & 1998 & 0,00 & 0 & 36,08 & 1 & $2.000,00$ \\
\hline Copene PNA & 1999 & 14,29 & 0 & 36,08 & 1 & $2.000,00$ \\
\hline Copene PNA & 2000 & 31,25 & 0 & 36,08 & 1 & $2.200,00$ \\
\hline Copene PNA & 2001 & 0,00 & 0 & 36,31 & 1 & $2.246,00$ \\
\hline Cosipa PN & 2000 & 40,00 & 0 & 33,33 & 1 & $1.140,00$ \\
\hline Cosipa PN & 2001 & 12,50 & 0 & 33,33 & 1 & $1.503,00$ \\
\hline Coteminas PN & 2000 & 23,08 & 1 & 41,19 & 1 & $5.411,00$ \\
\hline Coteminas PN & 2001 & 11,11 & 1 & 41,19 & 1 & $5.411,00$ \\
\hline Duratex PN & 1997 & 0,00 & 0 & 33,37 & 1 & $3.200,00$ \\
\hline Duratex PN & 1998 & 0,00 & 0 & 36,22 & 1 & $3.388,00$ \\
\hline Duratex PN & 1999 & 22,22 & 0 & 36,22 & 1 & $3.835,00$ \\
\hline Duratex PN & 2000 & 33,33 & 0 & 36,22 & 1 & $3.900,00$ \\
\hline Duratex PN & 2001 & 25,00 & 0 & 36,22 & 1 & $4.300,00$ \\
\hline EMAE PN & 2000 & 16,67 & 0 & 39,80 & 0 & 246,00 \\
\hline EMAE PN & 2001 & 13,04 & 0 & 39,80 & 0 & 246,00 \\
\hline Eletrobras PNB & 1997 & 0,00 & 0 & 84,19 & 0 & 741,00 \\
\hline Eletrobras PNB & 1998 & 0,00 & 0 & 84,19 & 0 & 777,00 \\
\hline Eletrobras PNB & 1999 & 21,05 & 0 & 84,19 & 0 & 918,00 \\
\hline Eletrobras PNB & 2000 & 60,00 & 0 & 84,19 & 0 & 944,00 \\
\hline Eletrobras PNB & 2001 & 20,00 & 0 & 84,19 & 0 & 782,00 \\
\hline Eletropaulo Metro & 1999 & 20,00 & 0 & 33,33 & 0 & 782,00 \\
\hline Eletropaulo Metro & 2000 & 33,33 & 0 & 39,80 & 0 & 782,00 \\
\hline Eletropaulo Metro & 2001 & 30,00 & 0 & 39,80 & 0 & 782,00 \\
\hline Embraer ON & 1999 & 20,00 & 0 & 49,54 & 1 & $6.662,00$ \\
\hline Embraer ON & 2000 & 16,67 & 0 & 44,63 & 1 & $14.259,00$ \\
\hline
\end{tabular}




\begin{tabular}{|c|c|c|c|c|c|c|}
\hline Empresas & Ano & CA_DIR & D1_CHAIR & PERT_AO & D2_LUCRO & REMUN_A \\
\hline Embraer ON & 2001 & 11,76 & 0 & 34,13 & 1 & $21.721,00$ \\
\hline Embratel Part PN & 1999 & 9,09 & 0 & 37,19 & 0 & $1.000,00$ \\
\hline Embratel Part PN & 2000 & 0,00 & 0 & 37,19 & 0 & $1.000,00$ \\
\hline Embratel Part PN & 2001 & 14,29 & 0 & 37,19 & 0 & $1.000,00$ \\
\hline F Cataguazes PNA & 1998 & 9,09 & 0 & 38,26 & 1 & $1.600,00$ \\
\hline F Cataguazes PNA & 1999 & 9,09 & 0 & 38,26 & 1 & $1.717,00$ \\
\hline F Cataguazes PNA & 2000 & 0,00 & 0 & 38,26 & 1 & $2.000,00$ \\
\hline F Cataguazes PNA & 2001 & 9,09 & 0 & 38,26 & 1 & $2.178,00$ \\
\hline Fosfertil PN & 1998 & 9,09 & 0 & 33,33 & 0 & 60,00 \\
\hline Fosfertil PN & 1999 & 9,09 & 0 & 33,33 & 0 & 60,00 \\
\hline Fosfertil PN & 2000 & 0,00 & 0 & 33,33 & 0 & 80,00 \\
\hline Fosfertil PN & 2001 & 0,00 & 0 & 33,80 & 0 & 90,00 \\
\hline Gerasul - Tracteb & 2000 & 0,00 & 0 & 76,80 & 1 & $3.094,00$ \\
\hline Gerasul - Tracteb & 2001 & 33,33 & 0 & 43,11 & 1 & $5.000,00$ \\
\hline Gerdau Met PN & 1997 & 0,00 & 0 & 33,33 & 1 & 13,00 \\
\hline Gerdau Met PN & 1998 & 9,09 & 1 & 33,33 & 1 & 13,00 \\
\hline Gerdau Met PN & 1999 & 9,09 & 1 & 33,33 & 0 & 30,00 \\
\hline Gerdau Met PN & 2000 & 0,00 & 0 & 33,33 & 1 & 30,00 \\
\hline Gerdau Met PN & 2001 & 0,00 & 1 & 33,33 & 1 & 30,00 \\
\hline Gerdau ON & 1997 & 11,11 & 0 & 34,70 & 1 & 13,00 \\
\hline Gerdau ON & 1998 & 9,09 & 1 & 34,70 & 1 & 13,00 \\
\hline Gerdau ON & 1999 & 11,11 & 1 & 34,70 & 1 & 60,00 \\
\hline Gerdau ON & 2000 & 0,00 & 0 & 34,70 & 1 & 60,00 \\
\hline Gerdau ON & 2001 & 0,00 & 1 & 34,69 & 1 & 60,00 \\
\hline Globo Cabo - Net & 1999 & 50,00 & 0 & 49,92 & 1 & 100,00 \\
\hline Globo Cabo - Net & 2000 & 0,00 & 0 & 43,11 & 1 & 500,00 \\
\hline Globo Cabo - Net & 2001 & 20,00 & 0 & 71,09 & 0 & $4.100,00$ \\
\hline Inepar Construcoe & 1997 & 10,00 & 0 & 37,69 & 1 & $24.000,00$ \\
\hline Inepar Construcoes & 1998 & 9,09 & 0 & 37,71 & 1 & $4.700,00$ \\
\hline Inepar Construcoes & 1999 & 42,86 & 0 & 34,33 & 1 & $4.700,00$ \\
\hline Inepar Construcoes & 2000 & 0,00 & 0 & 34,57 & 1 & $4.652,00$ \\
\hline Inepar Construcoes & 2001 & 20,00 & 0 & 34,57 & 1 & $3.345,00$ \\
\hline lochp-Maxion PN & 1997 & 10,00 & 0 & 43,73 & 1 & $3.357,00$ \\
\hline lochp-Maxion PN & 1998 & 18,18 & 0 & 34,00 & 1 & $2.419,00$ \\
\hline lochp-Maxion PN & 1999 & 50,00 & 0 & 34,00 & 1 & $2.060,00$ \\
\hline lochp-Maxion PN & 2000 & 0,00 & 0 & 34,00 & 1 & $2.055,00$ \\
\hline lochp-Maxion PN & 2001 & 20,00 & 0 & 34,00 & 1 & $1.764,00$ \\
\hline Ipiranga Pet PN & 1997 & 30,00 & 0 & 33,42 & 1 & $1.056,00$ \\
\hline Ipiranga Pet PN & 1998 & 9,09 & 0 & 33,42 & 1 & $1.534,00$ \\
\hline Ipiranga Pet PN & 1999 & 12,50 & 0 & 33,42 & 1 & $1.686,00$ \\
\hline Ipiranga Pet PN & 2000 & 33,33 & 0 & 33,42 & 1 & $1.469, \mathrm{C}$ \\
\hline Ipiranga Pet PN & 2001 & 21,05 & 0 & 33,42 & 1 & 1.569, \\
\hline Itausa PN & 1998 & 9,09 & 0 & 34,30 & 0 & $6.000,00$ \\
\hline Itausa PN & 1999 & 27,27 & 0 & 36,67 & 1 & $8.000,00$ \\
\hline Itausa PN & 2000 & 42,86 & 1 & 36,71 & 1 & $8.000,00$ \\
\hline Itausa PN & 2001 & 13,33 & 1 & 36,71 & 1 & $8.000,00$ \\
\hline Klabin PN & 1997 & 40,00 & 0 & 35,83 & 0 & $2.710,00$ \\
\hline Klabin PN & 1998 & 23,08 & 0 & 35,83 & 0 & $3.000, \mathrm{C}$ \\
\hline Klabin PN & 1999 & 33,33 & 0 & 35,83 & 0 & $3.100,00$ \\
\hline Klabin PN & 2000 & 0,00 & 0 & 34,54 & 1 & $3.000,00$ \\
\hline Kuala PN & 1999 & 22,22 & 0 & 33,33 & 0 & $1.500,00$ \\
\hline Kuala PN & 2000 & 0,00 & 0 & 33,33 & 0 & $1.200,00$ \\
\hline Kuala PN & 2001 & 15,38 & 0 & 33,33 & 0 & $1.200,0$ \\
\hline
\end{tabular}




\begin{tabular}{|c|c|c|c|c|c|c|}
\hline Empresas & Ano & CA_DIR & D1_CHAIR & PERT_AO & D2_LUCRO & REMUN_A \\
\hline Light ON & 2000 & 0,00 & 0 & 100,00 & 0 & $1.200,00$ \\
\hline Light ON & 2001 & 0,00 & 0 & 100,00 & 0 & $1.200,00$ \\
\hline Lojas Americanas & 1998 & 0,00 & 0 & 36,41 & 1 & 682,00 \\
\hline Lojas Americanas & 2000 & 25,00 & 0 & 36,24 & 1 & $1.092,00$ \\
\hline Lojas Americanas & 2001 & 0,00 & 0 & 37,48 & 1 & $1.200,00$ \\
\hline Magnesita PNA & 1997 & 40,00 & 0 & 52,57 & 1 & $1.325,00$ \\
\hline Magnesita PNA & 1998 & 0,00 & 0 & 52,57 & 1 & $1.342,00$ \\
\hline Magnesita PNA & 1999 & 0,00 & 0 & 52,57 & 1 & $1.356,00$ \\
\hline Magnesita PNA & 2000 & 33,33 & 0 & 52,57 & 1 & $1.622,00$ \\
\hline Magnesita PNA & 2001 & 14,29 & 0 & 52,57 & 1 & $1.805,00$ \\
\hline PETROBRAS BR & 1998 & 20,00 & 0 & 34,72 & 0 & $1.800,00$ \\
\hline PETROBRAS BR & 1999 & 0,00 & 0 & 34,72 & 0 & $1.800,00$ \\
\hline PETROBRAS BR & 2000 & 33,33 & 0 & 34,72 & 0 & 212,00 \\
\hline PETROBRAS BR & 2001 & 16,67 & 0 & 34,72 & 0 & 217,00 \\
\hline Petrobras PN & 1999 & 7,69 & 0 & 58,39 & 0 & 966,00 \\
\hline Petrobras PN & 2000 & 27,78 & 0 & 58,39 & 1 & $1.832,00$ \\
\hline Petrobras PN & 2001 & 50,00 & 0 & 58,39 & 1 & $2.419,00$ \\
\hline Plascar PN & 1997 & 40,00 & 1 & 56,53 & 0 & $1.000,00$ \\
\hline Plascar PN & 1998 & 22,22 & 1 & 56,53 & 0 & $1.000,00$ \\
\hline Plascar PN & 1999 & 14,29 & 1 & 56,53 & 0 & $1.000,00$ \\
\hline Plascar PN & 2000 & 31,58 & 1 & 56,53 & 0 & $1.000,00$ \\
\hline Plascar PN & 2001 & 33,33 & 1 & 56,53 & 0 & $1.000,00$ \\
\hline Ripasa PN & 1997 & 11,11 & 0 & 59,52 & 0 & $2.500,00$ \\
\hline Ripasa PN & 1998 & 12,50 & 0 & 59,52 & 0 & $1.200,00$ \\
\hline Ripasa PN & 1999 & 14,29 & 0 & 45,09 & 0 & $1.000,00$ \\
\hline Ripasa PN & 2000 & 0,00 & 0 & 45,09 & 0 & $1.274,00$ \\
\hline Ripasa PN & 2001 & 33,33 & 0 & 45,09 & 0 & $2.129,00$ \\
\hline Sabesp ON & 1997 & 11,11 & 0 & 100,00 & 0 & 780,00 \\
\hline Sabesp ON & 1998 & 11,11 & 0 & 100,00 & 0 & 862,00 \\
\hline Sabesp ON & 1999 & 40,00 & 0 & 100,00 & 0 & 886,00 \\
\hline Sabesp ON & 2000 & 0,00 & 0 & 100,00 & 0 & 885,00 \\
\hline Sabesp ON & 2001 & 0,00 & 0 & 100,00 & 0 & 958,00 \\
\hline Sid Nacional ON & 1998 & 28,57 & 0 & 100,00 & 0 & $3.677,00$ \\
\hline Sid Nacional ON & 1999 & 28,57 & 0 & 100,00 & 0 & $4.560,00$ \\
\hline Sid Nacional ON & 2000 & 11,11 & 0 & 100,00 & 0 & $3.235,00$ \\
\hline Sid Nacional ON & 2001 & 0,00 & 0 & 100,00 & 0 & $7.319,00$ \\
\hline Sid Tubarao PN & 1997 & 11,11 & 0 & 40,80 & 1 & $3.745,00$ \\
\hline Sid Tubarao PN & 1998 & 5,00 & 0 & 38,58 & 1 & $3.316,00$ \\
\hline Sid Tubarao PN & 1999 & 42,86 & 0 & 38,58 & 1 & $2.201,00$ \\
\hline Sid Tubarao PN & 2000 & 0,00 & 0 & 38,58 & 1 & $2.985,00$ \\
\hline Sid Tubarao PN & 2001 & 0,00 & 0 & 38,58 & 1 & $2.568,00$ \\
\hline Suzano PN & 2000 & 0,00 & 0 & 43,25 & 1 & 605, \\
\hline Suzano PN & 2001 & 25,00 & 0 & 44,02 & 1 & $2.100,00$ \\
\hline Tele Celular Sul & 1999 & 0,00 & 0 & 37,19 & 0 & $1.365,00$ \\
\hline Tele Celular Sul & 2000 & 0,00 & 0 & 37,72 & 0 & $1.750,00$ \\
\hline Tele Celular Sul & 2001 & 16,67 & 0 & 37,72 & 1 & $1.925,00$ \\
\hline Tele Centroeste C & 2000 & 12,50 & 0 & 34,13 & 0 & $1.500,00$ \\
\hline Tele Centroeste C & 2001 & 25,00 & 0 & 52,02 & 1 & $1.500,00$ \\
\hline Tele Leste Celula & 1999 & 0,00 & 1 & 37,19 & 0 & 800,00 \\
\hline Tele Leste Celula & 2000 & 14,29 & 0 & 34,63 & 0 & 948,00 \\
\hline Tele Leste Celula & 2001 & 16,67 & 0 & 34,63 & 0 & 576,00 \\
\hline Tele Nordeste Cel & 1999 & 0,00 & 0 & 37,19 & 0 & 749,00 \\
\hline Tele Nordeste Cel & 2000 & 11,11 & 0 & 37,19 & 0 & $1.200,00$ \\
\hline
\end{tabular}




\begin{tabular}{|c|c|c|c|c|c|c|}
\hline Empresas & Ano & CA_DIR & D1_CHAIR & PERT_AO & D2_LUCRO & REMUN_A \\
\hline Tele Nordeste Cel & 2001 & 16,67 & 0 & 37,82 & 0 & $1.200,00$ \\
\hline Tele Norte Celula & 1999 & 0,00 & 0 & 37,19 & 1 & $1.000,00$ \\
\hline Tele Norte Celula & 2000 & 33,33 & 0 & 37,19 & 1 & $1.600,00$ \\
\hline Tele Norte Celula & 2001 & 7,69 & 0 & 37,19 & 1 & 239,00 \\
\hline Tele Sudeste Celu & 1999 & 0,00 & 0 & 37,19 & 0 & $1.900,00$ \\
\hline Tele Sudeste Celu & 2000 & 33,33 & 0 & 34,47 & 0 & $4.303,00$ \\
\hline Tele Sudeste Celu & 2001 & 14,29 & 0 & 37,30 & 0 & $1.690,00$ \\
\hline Telemar Norte Les & 1999 & 0,00 & 0 & 72,84 & 0 & 182,00 \\
\hline Telemar Norte Les & 2000 & 50,00 & 0 & 72,84 & 0 & 107,00 \\
\hline Telemar Norte Les & 2001 & 10,00 & 0 & 43,69 & 1 & $5.890,00$ \\
\hline Telemar PN & 2000 & 20,00 & 0 & 33,33 & 0 & $11.497,00$ \\
\hline Telemar PN & 2001 & 10,00 & 0 & 33,33 & 1 & $18.587,00$ \\
\hline Telemig Celul Par & 1999 & 0,00 & 0 & 37,19 & 0 & $2.500,00$ \\
\hline Telemig Celul Par & 2000 & 20,00 & 0 & 37,19 & 1 & $1.520,00$ \\
\hline Telemig Celul Par & 2001 & 10,00 & 0 & 37,19 & 1 & $2.345,00$ \\
\hline Telemig Celular P & 1999 & 0,00 & 0 & 37,43 & 0 & 332,00 \\
\hline Telemig Celular P & 2000 & 33,33 & 0 & 37,43 & 1 & 800,00 \\
\hline Telemig Celular P & 2001 & 28,57 & 0 & 37,43 & 1 & $2.234,00$ \\
\hline Telepar Celular P & 1999 & 14,29 & 0 & 44,09 & 0 & 600,00 \\
\hline Telepar Celular P & 2000 & 66,67 & 0 & 56,27 & 0 & 400,00 \\
\hline Telepar Celular P & 2001 & 28,57 & 0 & 56,27 & 1 & 400,00 \\
\hline Telesp Cel Part P & 2000 & 50,00 & 0 & 34,94 & 0 & 87,00 \\
\hline Telesp Cel Part P & 2001 & 28,57 & 0 & 34,94 & 0 & $1.745,00$ \\
\hline Telesp Operac PN & 1999 & 0,00 & 0 & 33,60 & 1 & $6.240,00$ \\
\hline Telesp Operac PN & 2000 & 33,33 & 1 & 33,58 & 1 & $7.550,00$ \\
\hline Telesp Operac PN & 2001 & 28,57 & 0 & 33,58 & 1 & $10.080,00$ \\
\hline Transmissao Pauli & 2000 & 14,29 & 0 & 51,81 & 0 & 143,00 \\
\hline Transmissao Pauli & 2001 & 16,67 & 0 & 41,91 & 0 & 362,00 \\
\hline Trikem PN & 1997 & 11,11 & 1 & 35,31 & 1 & 825,00 \\
\hline Trikem PN & 1998 & 4,76 & 1 & 35,31 & 0 & 416,00 \\
\hline Trikem PN & 1999 & 33,33 & 0 & 35,31 & 0 & 346,00 \\
\hline Trikem PN & 2000 & 7,69 & 1 & 35,29 & 1 & 704,00 \\
\hline Trikem PN & 2001 & 0,00 & 0 & 35,29 & 1 & $3.200,00$ \\
\hline Ultrapar PN & 2000 & 11,11 & 1 & 71,67 & 1 & $3.469,00$ \\
\hline Ultrapar PN & 2001 & 0,00 & 1 & 71,67 & 1 & $3.726,00$ \\
\hline Unipar PNB & 1997 & 25,00 & 0 & 33,33 & 1 & $1.286,00$ \\
\hline Unipar PNB & 1998 & 0,00 & 0 & 33,33 & 1 & $1.131,00$ \\
\hline Unipar PNB & 1999 & 33,33 & 0 & 33,33 & 1 & $2.125,00$ \\
\hline Unipar PNB & 2000 & 14,29 & 0 & 33,33 & 1 & $2.060,00$ \\
\hline Unipar PNB & 2001 & 0,00 & 0 & 33,33 & 1 & $2.322,00$ \\
\hline Usiminas ON & 1997 & 14,29 & 0 & 33,33 & 1 & $1.014,00$ \\
\hline Usiminas ON & 1998 & 0,00 & 0 & 49,84 & 0 & $3.000,00$ \\
\hline Usiminas ON & 1999 & 66,67 & 0 & 49,84 & 0 & $5.706,00$ \\
\hline Usiminas ON & 2000 & 14,29 & 0 & 49,84 & 0 & $3.676,00$ \\
\hline Usiminas ON & 2001 & 0,00 & 0 & 49,84 & 0 & $5.423,00$ \\
\hline VCP & 1997 & 14,29 & 0 & 55,16 & 0 & $1.767,00$ \\
\hline V C P & 1998 & 0,00 & 0 & 55,16 & 0 & $2.534,00$ \\
\hline V C P & 1999 & 12,50 & 0 & 55,16 & 0 & $2.806,00$ \\
\hline VCP & 2000 & 0,00 & 0 & 55,16 & 0 & $3.948,00$ \\
\hline VCP & 2001 & 0,00 & 0 & 55,16 & 0 & $3.538,00$ \\
\hline Vale Rio Doce PNA & 1999 & 33,33 & 0 & 64,34 & 0 & $3.467,00$ \\
\hline Vale Rio Doce PNA & 2000 & 0,00 & 0 & 64,34 & 0 & $4.673,00$ \\
\hline Vale Rio Doce PNA & 2001 & 14,29 & 0 & 64,34 & 0 & $7.855,00$ \\
\hline
\end{tabular}




\begin{tabular}{l|r|r|r|r|r|r}
\hline \multicolumn{1}{c|}{ Empresas } & Ano & CA_DIR & D1_CHAIR & PERT_AO & D2_LUCRO & REMUN_A \\
\hline Varig PN & 1997 & 40,00 & 0 & 60,36 & 0 & $3.023,00$ \\
Varig PN & 1998 & 0,00 & 0 & 60,36 & 0 & $3.023,00$ \\
Varig PN & 1999 & 25,00 & 0 & 60,36 & 0 & $3.023,00$ \\
Varig PN & 2000 & 0,00 & 0 & 60,36 & 0 & $3.789,00$ \\
Varig PN & 2001 & 0,00 & 0 & 60,36 & 0 & $4.800,00$ \\
\hline
\end{tabular}

CONTINUA 


\begin{tabular}{|c|c|c|c|c|c|c|}
\hline Empresas & Ano & DEB_ASST & DIV_PRIC & DIV_EARN & D3_AUDIT & LG_TAM \\
\hline AES Tiete PN & 2000 & 69,76 & 4,30 & 21,28 & 1 & 6,24 \\
\hline AES Tiete PN & 2001 & 62,23 & 4,20 & 21,28 & 1 & 6,32 \\
\hline Acesita PN & 1997 & 45,02 & 3,89 & 62,02 & 1 & 6,64 \\
\hline Acesita PN & 1998 & 52,54 & 1,12 & 68,17 & 1 & 6,64 \\
\hline Acesita PN & 1999 & 43,44 & 1,86 & 68,17 & 1 & 6,59 \\
\hline Acesita PN & 2000 & 41,91 & 1,86 & 68,17 & 1 & 6,73 \\
\hline Acesita PN & 2001 & 42,85 & 1,86 & 68,17 & 1 & 6,72 \\
\hline Ambev PN & 2000 & 36,52 & 3,12 & 38,29 & 1 & 6,73 \\
\hline Ambev PN & 2001 & 25,38 & 1,54 & 38,29 & 1 & 6,94 \\
\hline Aracruz PNB & 1997 & 35,34 & 3,41 & 57,45 & 1 & 6,60 \\
\hline Aracruz PNB & 1998 & 38,85 & 1,30 & 182,30 & 1 & 6,60 \\
\hline Aracruz PNB & 1999 & 44,94 & 2,62 & 123,11 & 1 & 6,62 \\
\hline Aracruz PNB & 2000 & 39,39 & 0,61 & 131,37 & 1 & 6,59 \\
\hline Aracruz PNB & 2001 & 28,89 & 3,63 & 33,32 & 1 & 6,60 \\
\hline Bahia Sul PNA & 1999 & 45,95 & 2,74 & 16,71 & 1 & 6,33 \\
\hline Bahia Sul PNA & 2000 & 44,28 & 2,74 & 16,71 & 1 & 6,37 \\
\hline Bahia Sul PNA & 2001 & 35,75 & 2,74 & 16,71 & 1 & 6,38 \\
\hline Bardella PN & 1997 & 18,05 & 6,90 & 170,17 & 0 & 5,69 \\
\hline Bardella PN & 1998 & 18,88 & 6,40 & 46,92 & 0 & 5,69 \\
\hline Bardella PN & 1999 & 19,74 & 29,17 & 60,54 & 0 & 5,66 \\
\hline Bardella PN & 2000 & 0,53 & 12,02 & 66,08 & 0 & 5,52 \\
\hline Bardella PN & 2001 & 1,80 & 12,92 & 71,35 & 0 & 5,59 \\
\hline Belgo Mineira ON & 1998 & 30,91 & 4,09 & 54,12 & 1 & 6,55 \\
\hline Belgo Mineira ON & 1999 & 34,76 & 19,01 & 68,67 & 1 & 6,65 \\
\hline Belgo Mineira ON & 2000 & 39,14 & 1,72 & 33,07 & 1 & 6,73 \\
\hline Belgo Mineira ON & 2001 & 30,94 & 16,37 & 34,07 & 1 & 6,60 \\
\hline Bombril PN & 1997 & 35,67 & 3,78 & 33,07 & 1 & 6,29 \\
\hline Bombril PN & 1998 & 40,62 & 12,95 & 31,55 & 1 & 6,29 \\
\hline Bombril PN & 1999 & 23,01 & 12,95 & 95,37 & 1 & 6,06 \\
\hline Bombril PN & 2000 & 18,50 & 3,75 & 20,75 & 1 & 6,09 \\
\hline Bombril PN & 2001 & 24,41 & 6,06 & 13,59 & 1 & 6,16 \\
\hline Brasil T Par PN & 1999 & 0,37 & 6,06 & 31,05 & 1 & 6,89 \\
\hline Brasil T Par PN & 2000 & 4,94 & 2,49 & 92,15 & 1 & 6,98 \\
\hline Brasil T Par PN & 2001 & 24,92 & 0,02 & 41,78 & 1 & 7,15 \\
\hline Brasil Telecom PN & 1999 & 15,27 & 10,64 & 35,23 & 1 & 6,41 \\
\hline Brasil Telecom PN & 2000 & 18,34 & 3,18 & 15,00 & 1 & 6,41 \\
\hline Brasil Telecom PN & 2001 & 25,72 & 10,16 & 45,10 & 1 & 7,10 \\
\hline CRT Celular PNA & 2000 & 39,73 & 0,00 & 0,00 & 1 & 6,04 \\
\hline CRT Celular PNA & 2001 & 32,00 & 0,00 & 0,00 & 1 & 6,13 \\
\hline Caemi Metal PN & 2000 & 46,89 & 1,39 & 12,96 & 1 & 6,34 \\
\hline Caemi Metal PN & 2001 & 42,34 & 0,33 & 4,92 & 1 & 6,37 \\
\hline Celesc PNB & 1997 & 2,04 & 1,38 & 23,75 & 1 & 6,31 \\
\hline Celesc PNB & 1998 & 4,64 & 1,38 & 23,75 & 1 & 6,31 \\
\hline Celesc PNB & 1999 & 7,39 & 2,74 & 23,00 & 1 & 6,37 \\
\hline Celesc PNB & 2000 & 9,29 & 0,15 & 65,71 & 1 & 6,37 \\
\hline Celesc PNB & 2001 & 9,05 & 0,09 & 25,16 & 1 & 6,41 \\
\hline Cemig PN & 1997 & 8,40 & 2,82 & 61,56 & 1 & 7,05 \\
\hline Cemig PN & 1998 & 9,62 & 3,33 & 87,96 & 1 & 7,05 \\
\hline Cemig PN & 1999 & 10,02 & 15,94 & 97,35 & 1 & 7,05 \\
\hline Cemig PN & 2000 & 12,91 & 5,51 & 815,47 & 1 & 7,06 \\
\hline
\end{tabular}




\begin{tabular}{|c|c|c|c|c|c|c|}
\hline Empresas & Ano & DEB_ASST & DIV_PRIC & DIV_EARN & D3_AUDIT & LG_TAM \\
\hline Cemig PN & 2001 & 14,26 & 4,17 & 45,06 & 1 & 7,08 \\
\hline Cesp PN & 1998 & 22,54 & 5,84 & 29,31 & 1 & 7,43 \\
\hline Cesp PN & 2000 & 36,07 & 5,15 & 188,41 & 1 & 7,30 \\
\hline Cesp PN & 2001 & 37,41 & 15,83 & 165,00 & 1 & 7,29 \\
\hline Cim Itau PN & 1997 & 13,69 & 3,09 & 163,83 & 0 & 5,98 \\
\hline Cim Itau PN & 1998 & 12,05 & 5,24 & 80,88 & 1 & 5,98 \\
\hline Cim Itau PN & 1999 & 11,81 & 8,19 & 40,16 & 1 & 6,02 \\
\hline Cim Itau PN & 2000 & 8,84 & 7,53 & 33,26 & 1 & 6,03 \\
\hline Cim Itau PN & 2001 & 4,93 & 5,25 & 25,80 & 1 & 6,08 \\
\hline Coelce PNA & 1998 & 14,87 & 0,00 & 44,18 & 1 & 5,94 \\
\hline Coelce PNA & 1999 & 14,27 & 5,50 & 97,05 & 1 & 5,98 \\
\hline Coelce PNA & 2000 & 8,25 & 8,15 & 61,56 & 1 & 6,25 \\
\hline Coelce PNA & 2001 & 11,24 & 5,71 & 0,00 & 1 & 6,28 \\
\hline Comgas PNA & 1997 & 23,89 & 0,00 & 0,00 & 1 & 5,80 \\
\hline Comgas PNA & 1998 & 16,98 & 0,00 & 23,75 & 1 & 5,80 \\
\hline Comgas PNA & 1999 & 15,68 & 0,29 & 0,00 & 1 & 5,81 \\
\hline Comgas PNA & 2000 & 28,16 & 0,00 & 0,00 & 1 & 5,79 \\
\hline Comgas PNA & 2001 & 15,95 & 0,00 & 23,31 & 1 & 6,12 \\
\hline Confab PN & 1997 & 6,25 & 0,00 & 52,90 & 1 & 5,75 \\
\hline Confab PN & 1998 & 13,98 & 5,53 & 44,00 & 1 & 5,75 \\
\hline Confab PN & 1999 & 13,84 & 16,76 & 33,79 & 1 & 5,75 \\
\hline Confab PN & 2000 & 14,70 & 14,84 & 38,62 & 1 & 5,70 \\
\hline Confab PN & 2001 & 14,30 & 13,10 & 38,51 & 1 & 5,70 \\
\hline Copel PNB & 1997 & 10,89 & 12,34 & 60,25 & 1 & 6,87 \\
\hline Copel PNB & 1998 & 15,06 & 5,08 & 49,58 & 1 & 6,87 \\
\hline Copel PNB & 2000 & 18,42 & 2,99 & 44,30 & 1 & 6,89 \\
\hline Copel PNB & 2001 & 17,34 & 4,37 & 37,16 & 1 & 6,90 \\
\hline Copene PNA & 1997 & 14,30 & 0,00 & 0,00 & 1 & 6,60 \\
\hline Copene PNA & 1998 & 10,89 & 0,00 & 0,00 & 1 & 6,60 \\
\hline Copene PNA & 1999 & 15,06 & 0,00 & 0,00 & 1 & 6,50 \\
\hline Copene PNA & 2000 & 18,42 & 0,00 & 0,00 & 1 & 6,55 \\
\hline Copene PNA & 2001 & 17,34 & 0,00 & 0,00 & 1 & 6,57 \\
\hline Cosipa PN & 2000 & 39,93 & 0,00 & 0,00 & 1 & 6,61 \\
\hline Cosipa PN & 2001 & 48,01 & 0,00 & 0,00 & 1 & 6,69 \\
\hline Coteminas PN & 2000 & 14,15 & 2,18 & 83,36 & 1 & 6,07 \\
\hline Coteminas PN & 2001 & 11,44 & 4,35 & 33,90 & 1 & 6,14 \\
\hline Duratex PN & 1997 & 16,58 & 2,67 & 31,83 & 1 & 6,04 \\
\hline Duratex PN & 1998 & 24,86 & 3,20 & 34,60 & 1 & 6,04 \\
\hline Duratex PN & 1999 & 27,44 & 7,47 & 34,84 & 1 & 6,06 \\
\hline Duratex PN & 2000 & 24,46 & 1,46 & 149,61 & 1 & 6,05 \\
\hline Duratex PN & 2001 & 25,21 & 3,74 & 32,25 & 1 & 6,16 \\
\hline EMAE PN & 2000 & 0,00 & 0,27 & 0,00 & 0 & 6,04 \\
\hline EMAE PN & 2001 & 0,00 & 0,00 & 23,75 & 0 & 6,04 \\
\hline Eletrobras PNB & 1997 & 17,32 & 4,48 & 31,21 & 1 & 7,99 \\
\hline Eletrobras PNB & 1998 & 9,63 & 3,62 & 44,00 & 1 & 7,99 \\
\hline Eletrobras PNB & 1999 & 10,41 & 12,22 & 16,75 & 1 & 7,95 \\
\hline Eletrobras PNB & 2000 & 13,48 & 11,02 & 106,19 & 1 & 7,93 \\
\hline Eletrobras PNB & 2001 & 18,44 & 8,13 & 32,62 & 1 & 7,96 \\
\hline Eletropaulo Metro & 1999 & 23,60 & 0,00 & 0,00 & 1 & 6,87 \\
\hline Eletropaulo Metro & 2000 & 23,55 & 0,00 & 39,69 & 1 & 6,91 \\
\hline Eletropaulo Metro & 2001 & 31,83 & 15,12 & 194,42 & 1 & 6,94 \\
\hline Embraer ON & 1999 & 39,67 & 3,07 & 41,84 & 1 & 6,31 \\
\hline Embraer ON & 2000 & 38,16 & 1,88 & 29,97 & 1 & 6,54 \\
\hline
\end{tabular}




\begin{tabular}{|c|c|c|c|c|c|c|}
\hline Empresas & Ano & DEB_ASST & DIV_PRIC & DIV_EARN & D3_AUDIT & LG_TAM \\
\hline Embraer ON & 2001 & 21,06 & 3,08 & 44,60 & 1 & 6,71 \\
\hline Embratel Part PN & 1999 & 8,22 & 0,00 & 65,45 & 1 & 6,91 \\
\hline Embratel Part PN & 2000 & 15,34 & 1,81 & 37,20 & 1 & 6,98 \\
\hline Embratel Part PN & 2001 & 19,10 & 1,69 & 37,11 & 1 & 7,07 \\
\hline F Cataguazes PNA & 1998 & 44,69 & 8,06 & 51,04 & 1 & 6,00 \\
\hline F Cataguazes PNA & 1999 & 45,66 & 0,00 & 0,00 & 1 & 6,04 \\
\hline F Cataguazes PNA & 2000 & 50,96 & 0,00 & 0,00 & 1 & 6,11 \\
\hline F Cataguazes PNA & 2001 & 38,48 & 6,91 & 117,67 & 1 & 6,34 \\
\hline Fosfertil PN & 1998 & 37,13 & 12,58 & 151,83 & 1 & 6,04 \\
\hline Fosfertil PN & 1999 & 32,99 & 35,81 & 126,56 & 1 & 6,00 \\
\hline Fosfertil PN & 2000 & 35,14 & 6,00 & 56,84 & 1 & 6,10 \\
\hline Fosfertil PN & 2001 & 37,57 & 16,87 & 65,92 & 1 & 6,14 \\
\hline Gerasul - Tracteb & 2000 & 32,71 & 1,08 & 0,00 & 1 & 6,62 \\
\hline Gerasul - Tracteb & 2001 & 36,97 & 0,00 & 84,03 & 1 & 6,71 \\
\hline Gerdau Met PN & 1997 & 27,74 & 7,37 & 0,00 & 1 & 6,47 \\
\hline Gerdau Met PN & 1998 & 29,96 & 10,90 & 0,00 & 1 & 6,47 \\
\hline Gerdau Met PN & 1999 & 32,65 & 16,95 & 49,43 & 1 & 6,54 \\
\hline Gerdau Met PN & 2000 & 45,85 & 6,14 & 49,22 & 1 & 6,81 \\
\hline Gerdau Met PN & 2001 & 45,71 & 8,59 & 54,84 & 1 & 6,84 \\
\hline Gerdau ON & 1997 & 15,97 & 4,93 & 29,71 & 1 & 6,45 \\
\hline Gerdau ON & 1998 & 20,45 & 8,27 & 30,92 & 1 & 6,45 \\
\hline Gerdau ON & 1999 & 24,30 & 12,05 & 31,23 & 1 & 6,52 \\
\hline Gerdau ON & 2000 & 45,51 & 3,71 & 27,76 & 1 & 6,80 \\
\hline Gerdau ON & 2001 & 46,14 & 6,66 & 31,89 & 1 & 6,84 \\
\hline Globo Cabo - Net & 1999 & 54,60 & 0,00 & 0,00 & 1 & 6,16 \\
\hline Globo Cabo - Net & 2000 & 61,82 & 0,00 & 0,00 & 1 & 6,17 \\
\hline Globo Cabo - Net & 2001 & 69,42 & 0,00 & 0,00 & 1 & 6,35 \\
\hline Inepar Construcoe & 1997 & 45,19 & 3,33 & 26,78 & 0 & 6,06 \\
\hline Inepar Construcoes & 1998 & 26,45 & 8,87 & 26,24 & 1 & 6,06 \\
\hline Inepar Construcoes & 1999 & 27,72 & 7,67 & 62,22 & 1 & 6,47 \\
\hline Inepar Construcoes & 2000 & 22,64 & 2,71 & 0,00 & 1 & 6,22 \\
\hline Inepar Construcoes & 2001 & 33,04 & 0,00 & 0,00 & 1 & 6,18 \\
\hline lochp-Maxion PN & 1997 & 42,00 & 0,00 & 0,00 & 1 & 5,88 \\
\hline lochp-Maxion PN & 1998 & 43,08 & 0,00 & 0,00 & 1 & 5,88 \\
\hline lochp-Maxion PN & 1999 & 36,32 & 0,00 & 0,00 & 1 & 5,79 \\
\hline lochp-Maxion PN & 2000 & 47,86 & 0,00 & 0,00 & 1 & 5,81 \\
\hline lochp-Maxion PN & 2001 & 50,23 & 4,32 & 55,18 & 1 & 5,82 \\
\hline Ipiranga Pet PN & 1997 & 13,05 & 3,84 & 31,27 & 1 & 6,07 \\
\hline Ipiranga Pet PN & 1998 & 11,17 & 8,16 & 36,62 & 1 & 6,07 \\
\hline Ipiranga Pet PN & 1999 & 14,79 & 24,61 & 39,10 & 1 & 6,15 \\
\hline Ipiranga Pet PN & 2000 & 17,99 & 3,63 & 37,28 & 1 & 6,19 \\
\hline Ipiranga Pet PN & 2001 & 12,80 & 2,73 & 48,55 & 1 & 6,21 \\
\hline Itausa PN & 1998 & 12,80 & 2,68 & 70,92 & 1 & 7,69 \\
\hline Itausa PN & 1999 & 1,56 & 13,27 & 44,47 & 1 & 7,71 \\
\hline Itausa PN & 2000 & 1,69 & 4,57 & 60,85 & 1 & 7,73 \\
\hline Itausa PN & 2001 & 1,37 & 4,27 & 76,53 & 1 & 7,86 \\
\hline Klabin PN & 1997 & 35,88 & 3,23 & 55,37 & 1 & 6,45 \\
\hline Klabin PN & 1998 & 41,28 & 2,92 & 0,00 & 1 & 6,45 \\
\hline Klabin PN & 1999 & 42,66 & 1,43 & 0,00 & 1 & 6,44 \\
\hline Klabin PN & 2000 & 51,25 & 0,71 & 0,00 & 1 & 6,50 \\
\hline Kuala PN & 1999 & 32,55 & 0,00 & 0,00 & 1 & 5,19 \\
\hline Kuala PN & 2000 & 48,45 & 0,00 & 0,00 & 1 & 5,07 \\
\hline Kuala PN & 2001| & 0,00 & 0,00 & 0,00 & 1 & 4,82 \\
\hline
\end{tabular}




\begin{tabular}{|c|c|c|c|c|c|c|}
\hline Empresas & Ano & DEB_ASST & DIV_PRIC & DIV_EARN & D3_AUDIT & LG_TAM \\
\hline Light ON & 2000 & 43,13 & 0,00 & 0,00 & 1 & 7,15 \\
\hline Light ON & 2001 & 49,74 & 0,00 & 0,00 & 1 & 7,18 \\
\hline Lojas Americanas & 1998 & 30,00 & 0,00 & 0,00 & 1 & 6,04 \\
\hline Lojas Americanas & 2000 & 40,80 & 1,09 & 25,28 & 1 & 6,00 \\
\hline Lojas Americanas & 2001 & 41,81 & 5,56 & 0,00 & 1 & 6,02 \\
\hline Magnesita PNA & 1997 & 23,62 & 8,94 & 25,64 & 1 & 5,59 \\
\hline Magnesita PNA & 1998 & 16,75 & 13,88 & 28,28 & 1 & 5,59 \\
\hline Magnesita PNA & 1999 & 11,60 & 19,09 & 28,01 & 1 & 5,60 \\
\hline Magnesita PNA & 2000 & 3,97 & 8,06 & 28,60 & 1 & 5,63 \\
\hline Magnesita PNA & 2001 & 1,73 & 10,12 & 29,68 & 1 & 5,69 \\
\hline PETROBRAS BR & 1998 & 14,27 & 5,74 & 32,49 & 1 & 6,32 \\
\hline PETROBRAS BR & 1999 & 0,00 & 10,76 & 23,75 & 1 & 6,39 \\
\hline PETROBRAS BR & 2000 & 0,00 & 4,97 & 0,00 & 1 & 6,44 \\
\hline PETROBRAS BR & 2001 & 0,00 & 0,00 & 28,15 & 1 & 6,52 \\
\hline Petrobras PN & 1999 & 29,89 & 4,49 & 44,90 & 1 & 7,60 \\
\hline Petrobras PN & 2000 & 33,61 & 1,40 & 50,40 & 1 & 7,75 \\
\hline Petrobras PN & 2001 & 25,80 & 1,78 & 26,10 & 1 & 7,83 \\
\hline Plascar PN & 1997 & 15,32 & 0,97 & 0,00 & 1 & 5,34 \\
\hline Plascar PN & 1998 & 14,84 & 0,00 & 25,11 & 1 & 5,34 \\
\hline Plascar PN & 1999 & 25,98 & 7,33 & 0,00 & 1 & 5,38 \\
\hline Plascar PN & 2000 & 36,16 & 0,00 & 0,00 & 1 & 5,32 \\
\hline Plascar PN & 2001 & 34,78 & 0,00 & 0,00 & 1 & 5,26 \\
\hline Ripasa PN & 1997 & 27,70 & 13,61 & 0,00 & 1 & 6,00 \\
\hline Ripasa PN & 1998 & 30,89 & 0,00 & 0,00 & 1 & 6,00 \\
\hline Ripasa PN & 1999 & 28,52 & 0,00 & 0,00 & 1 & 5,98 \\
\hline Ripasa PN & 2000 & 25,79 & 0,00 & 34,50 & 1 & 6,02 \\
\hline Ripasa PN & 2001 & 14,25 & 19,86 & 27,66 & 1 & 6,04 \\
\hline Sabesp ON & 1997 & 27,21 & 0,00 & 24,12 & 0 & 7,14 \\
\hline Sabesp ON & 1998 & 30,47 & 1,65 & 38,23 & 0 & 7,14 \\
\hline Sabesp ON & 1999 & 33,66 & 14,98 & 94,91 & 1 & 7,16 \\
\hline Sabesp ON & 2000 & 38,80 & 2,23 & 0,00 & 1 & 7,18 \\
\hline Sabesp ON & 2001 & 39,48 & 10,90 & 103,49 & 1 & 7,18 \\
\hline Sid Nacional ON & 1998 & 41,80 & 12,38 & 51,75 & 1 & 6,94 \\
\hline Sid Nacional ON & 1999 & 39,81 & 14,67 & 56,46 & 1 & 6,93 \\
\hline Sid Nacional ON & 2000 & 36,49 & 3,78 & 123,22 & 1 & 7,10 \\
\hline Sid Nacional ON & 2001 & 33,76 & 9,28 & 107,90 & 1 & 7,18 \\
\hline Sid Tubarao PN & 1997 & 22,15 & 8,64 & 55,26 & 1 & 6,68 \\
\hline Sid Tubarao PN & 1998 & 30,10 & 7,51 & 57,60 & 1 & 6,68 \\
\hline Sid Tubarao PN & 1999 & 31,75 & 25,32 & 66,81 & 1 & 6,69 \\
\hline Sid Tubarao PN & 2000 & 30,06 & 0,00 & 0,00 & 1 & 6,81 \\
\hline Sid Tubarao PN & 2001 & 29,84 & 10,82 & 89,50 & 1 & 6,81 \\
\hline Suzano PN & 2000 & 39,08 & 0,00 & 38,46 & 1 & 6,54 \\
\hline Suzano PN & 2001 & 32,50 & 4,18 & 15,19 & 1 & 6,60 \\
\hline Tele Celular Sul & 1999 & 6,65 & 4,72 & 29,14 & 1 & 5,96 \\
\hline Tele Celular Sul & 2000 & 19,28 & 0,99 & 50,18 & 1 & 6,06 \\
\hline Tele Celular Sul & 2001 & 24,14 & 0,15 & 76,50 & 1 & 6,16 \\
\hline Tele Centroeste C & 2000 & 8,88 & 4,74 & 41,59 & 1 & 6,17 \\
\hline Tele Centroeste C & 2001 & 26,58 & 1,48 & 33,83 & 1 & 6,28 \\
\hline Tele Leste Celula & 1999 & 20,20 & 7,76 & 52,71 & 1 & 5,65 \\
\hline Tele Leste Celula & 2000 & 55,38 & 1,68 & 0,00 & 1 & 5,82 \\
\hline Tele Leste Celula & 2001 & 38,37 & 0,00 & 0,00 & 1 & 5,96 \\
\hline Tele Nordeste Cel & 1999 & 16,74 & 7,07 & 0,00 & 1 & 5,84 \\
\hline Tele Nordeste Cel & 2000 & 33,38 & 0,91 & 143,71 & 1 & 5,99 \\
\hline
\end{tabular}




\begin{tabular}{|c|c|c|c|c|c|c|}
\hline Empresas & Ano & DEB_ASST & DIV_PRIC & DIV_EARN & D3_AUDIT & LG_TAM \\
\hline Tele Nordeste Cel & 2001 & 32,85 & 0,58 & 38,71 & 1 & 6,09 \\
\hline Tele Norte Celula & 1999 & 10,37 & 0,00 & 19,73 & 1 & 5,58 \\
\hline Tele Norte Celula & 2000 & 19,06 & 1,53 & 16,14 & 1 & 5,82 \\
\hline Tele Norte Celula & 2001 & 41,62 & 0,95 & 88,51 & 1 & 5,92 \\
\hline Tele Sudeste Celu & 1999 & 2,55 & 4,24 & 48,38 & 1 & 6,14 \\
\hline Tele Sudeste Celu & 2000 & 26,55 & 0,15 & 58,84 & 1 & 6,29 \\
\hline Tele Sudeste Celu & 2001 & 21,09 & 2,76 & 38,49 & 1 & 6,43 \\
\hline Telemar Norte Les & 1999 & 25,53 & 28,45 & 0,00 & 1 & 6,68 \\
\hline Telemar Norte Les & 2000 & 7,73 & 0,00 & 0,00 & 1 & 6,71 \\
\hline Telemar Norte Les & 2001 & 14,80 & 0,00 & 0,00 & 1 & 6,76 \\
\hline Telemar PN & 2000 & 5,45 & 1,42 & 262,30 & 1 & 7,26 \\
\hline Telemar PN & 2001 & 14,54 & 1,44 & 57,66 & 1 & 7,29 \\
\hline Telemig Celul Par & 1999 & 6,92 & 0,00 & 0,00 & 1 & 5,88 \\
\hline Telemig Celul Par & 2000 & 18,05 & 1,55 & 72,01 & 1 & 6,20 \\
\hline Telemig Celul Par & 2001 & 33,96 & 0,00 & 0,00 & 1 & 6,15 \\
\hline Telemig Celular P & 1999 & 7,35 & 0,00 & 0,00 & 1 & 5,85 \\
\hline Telemig Celular P & 2000 & 33,19 & 0,77 & 87,62 & 1 & 5,93 \\
\hline Telemig Celular P & 2001 & 43,12 & 3,67 & 57,23 & 1 & 6,04 \\
\hline Telepar Celular P & 1999 & 27,35 & 7,33 & 34,63 & 1 & 5,68 \\
\hline Telepar Celular P & 2000 & 53,07 & 0,00 & 0,00 & 1 & 5,87 \\
\hline Telepar Celular P & 2001 & 37,76 & 0,00 & 0,00 & 1 & 5,94 \\
\hline Telesp Cel Part P & 2000 & 30,98 & 0,99 & 58,26 & 1 & 6,74 \\
\hline Telesp Cel Part P & 2001 & 22,56 & 1,18 & 65,95 & 1 & 6,79 \\
\hline Telesp Operac PN & 1999 & 3,73 & 15,35 & 69,81 & 1 & 7,16 \\
\hline Telesp Operac PN & 2000 & 6,00 & 8,69 & 133,33 & 1 & 7,25 \\
\hline Telesp Operac PN & 2001 & 9,50 & 6,93 & 55,74 & 1 & 7,30 \\
\hline Transmissao Pauli & 2000 & 1,70 & 0,00 & 0,00 & 1 & 6,61 \\
\hline Transmissao Pauli & 2001 & 2,09 & 3,14 & 76,31 & 1 & 6,62 \\
\hline Trikem PN & 1997 & 34,69 & 2,94 & 0,00 & 1 & 6,36 \\
\hline Trikem PN & 1998 & 45,42 & 0,00 & 0,00 & 1 & 6,36 \\
\hline Trikem PN & 1999 & 45,41 & 0,00 & 0,00 & 1 & 6,32 \\
\hline Trikem PN & 2000 & 53,09 & 0,00 & 0,00 & 1 & 6,30 \\
\hline Trikem PN & 2001 & 49,78 & 0,00 & 0,00 & 1 & 6,33 \\
\hline Ultrapar PN & 2000 & 24,41 & 0,00 & 73,93 & 1 & 6,28 \\
\hline Ultrapar PN & 2001 & 21,14 & 4,89 & 42,28 & 1 & 6,30 \\
\hline Unipar PNB & 1997 & 34,49 & 14,46 & 85,83 & 1 & 5,84 \\
\hline Unipar PNB & 1998 & 38,91 & 0,00 & 0,00 & 1 & 5,84 \\
\hline Unipar PNB & 1999 & 33,51 & 12,00 & 0,00 & 1 & 5,85 \\
\hline Unipar PNB & 2000 & 24,18 & 10,05 & 26,31 & 1 & 5,93 \\
\hline Unipar PNB & 2001 & 22,65 & 12,35 & 27,44 & 1 & 5,98 \\
\hline Usiminas ON & 1997 & 21,10 & 6,94 & 63,95 & 1 & 6,95 \\
\hline Usiminas ON & 1998 & 28,01 & 14,86 & 55,59 & 1 & 6,95 \\
\hline Usiminas ON & 1999 & 36,92 & 15,90 & 45,10 & 1 & 6,97 \\
\hline Usiminas ON & 2000 & 44,06 & 2,96 & 27,34 & 1 & 7,07 \\
\hline Usiminas ON & 2001 & 48,47 & 6,23 & 44,47 & 1 & 7,11 \\
\hline VCP & 1997 & 24,61 & 0,59 & 0,00 & 1 & 6,47 \\
\hline V C P & 1998 & 30,34 & 2,99 & 57,43 & 1 & 6,47 \\
\hline VCP & 1999 & 34,67 & 2,11 & 0,00 & 1 & 6,48 \\
\hline VCP & 2000 & 32,68 & 0,00 & 25,16 & 1 & 6,52 \\
\hline VCP & 2001 & 25,44 & 7,28 & 26,21 & 1 & 6,54 \\
\hline Vale Rio Doce PNA & 1999 & 30,25 & 19,37 & 71,11 & 1 & 7,23 \\
\hline Vale Rio Doce PNA & 2000 & 32,66 & 4,56 & 70,17 & 1 & 7,30 \\
\hline Vale Rio Doce PNA & 2001| & 33,16 & 7,54 & 60,11 & 1 & 7,38 \\
\hline
\end{tabular}




\begin{tabular}{l|l|r|r|r|r|r}
\hline \multicolumn{1}{c|}{ Empresas } & Ano & DEB_ASST & DIV_PRIC & DIV_EARN & D3_AUDIT & LG_TAM \\
\hline Varig PN & 1997 & 69,80 & 0,00 & 0,00 & 1 & 6,54 \\
Varig PN & 1998 & 65,58 & 0,00 & 0,00 & 1 & 6,54 \\
Varig PN & 1999 & 59,92 & 0,00 & 0,00 & 1 & 6,36 \\
Varig PN & 2000 & 49,64 & 0,00 & 0,00 & 1 & 6,45 \\
Varig PN & 2001 & 61,34 & 0,00 & 0,00 & 1 & 6,49 \\
\hline
\end{tabular}

